\title{
11. CRETACEOUS CALCAREOUS NANNOFOSSILS FROM THE ANGOLA BASIN, DEEP SEA DRILLING PROJECT SITE 530 ${ }^{1}$
}

\author{
Herbert Stradner, Geologische Bundesanstalt, A-1031, Vienna, Austria \\ and \\ John Steinmetz, ${ }^{2}$ Department of Marine Science, University of South Florida, St. Petersburg, Florida \\ With a contribution by Lilian Svábenická, ${ }^{3}$ Geological Survey, Prague, Czechoslovakia
}

\begin{abstract}
The analyses of nannofossils in 517 samples from the Cretaceous sediment sequence of Hole 530A has resulted in the biostratigraphic assignment of these sediments to 13 different nannofossil zones from late Albian to late Maestrichtian. The nannofossil biohorizons marked by the first and last occurrences of guide-species are the basis of the range charts. These nannofossil biohorizons are correlated with the position of the paleomagnetic anomalies, and the timespan covered by each nannofossil zone is discussed. The results of the Cretaceous from Hole 530A are correlated with those from other sites in the South Atlantic, where Cretaceous sediments were cored.

One new nannofossil zone, the Liliasterites angularis Zone, and three new species, L. angularis, L. atlanticus, and Micula swastica are described. These and the majority of the other 90 species, which were encountered in the Cretaceous sequence from Cores 50 to 105, are shown in 52 plates in light- and electron-microscope micrographs.
\end{abstract}

\section{INTRODUCTION}

Site 530, where Cretaceous sediments were found in Hole $530 \mathrm{~A}$, is located in the southeastern corner of the Angola Basin, about $20 \mathrm{~km}$ north of the Walvis Escarpment near the eastern end of the Walvis Ridge (Fig. 1). It lies on the abyssal floor of the Angola Basin, at a depth of $4629 \mathrm{~m}$ below sea level. Its geographic position is $19^{\circ} 11.26^{\prime} \mathrm{S}$ to $9^{\circ} 23.15^{\prime} \mathrm{E}$. The Cretaceous/Tertiary boundary lies in Core 50 at about $592.5 \mathrm{~m}$ below seafloor; the basement was reached in Core 105 at $1103 \mathrm{~m}$. The thickness of Cretaceous sediments from upper $\mathrm{Al}$ bian overlying basalt to the uppermost Maestrichtian is $510.5 \mathrm{~m}$.

A total of 537 slides containing the fine fractions of the sediment samples were studied with a polarizing microscope Zetopan-Pol by Reichert-Wien, at magnifications between 600 and $1200 \times$. The nannofossil assemblages were analyzed, then the frequency of each species and the state of preservation were determined. Only a small number of better preserved samples with high nannofossil contents were further processed by ultrasonification and centrifugation. The cleaned residues were dried, gold-sputtered, and examined in a scanning electron microscope, the S 150 by Cambridge Instruments. Species are listed alphabetically by epithet in the appendix to the chapter, along with authors names and references to the plates. Data on occurrences, frequencies, and states of preservation for each species in each sample appear in seven range charts (Tables 1-8). There the species are listed in alphabetical order after their species epithets, as in the species list.

\footnotetext{
${ }^{1}$ Hay, w. W., Sibuet, J.-C., et al., Init. Repts. DSDP, 75: Washington (U.S. Govt. Printing Office).

${ }^{2}$ Present address: Denver Research Center, Marathon Oil Company, Littleton, Colo-

${ }_{3}$ Present address: Malstranské Nám. 1911821 Praha 1, Prague, Czechoslovakia.
}

As a result of poor or moderate preservation of the Cretaceous samples from Hole 530A, only a selection of the more common and corrosion-resistant species are documented in the plates. In a few cases, these plates also contain type specimens from other regions of the world for purposes of comparison and determination of critical species.

The main task of the shipboard nannopaleontologist is to provide biostratigraphic data of the core material as soon as the core is up on the deck; nannopaleontological methods have been advanced to such a degree that a quick survey can be furnished within a comparatively short time. However, when quantitative data have to be collected, and when scanning electron microscopy and light microphotography are also planned, then a very generous amount of time must be calculated for the task.

Paleomagnetic data which became available after the cruise had ended proved to be of enormous importance for correlating nannofossil biohorizons with magnetic anomalies and finding their place in the Cretaceous time scale (compare Figs. 2-4). It was rewarding to correlate the paleomagnetic data furnished by Keating and Herrero-Bervera (this volume) with other paleomagnetic time scales in which magnetic anomalies and nannofossil biohorizons were listed in parallel columns. In Figures 3 and 4 a different approach was attempted. Keating and Herrero-Bervera's magnetostratigraphy of Hole 530A was taken as "standard," and six other stratigraphic charts, from Van Hinte (1976) to Lowrie and Alvarez (1981), were compared to see to what extent time intervals assigned to nannoplankton zones agree. For further details, see the chapters on biostratigraphy and magnetostratigraphy.

\section{BIOSTRATIGRAPHY}

The evaluation of data on the distribution of calcareous nannofossils within an ocean floor profile is an es- 


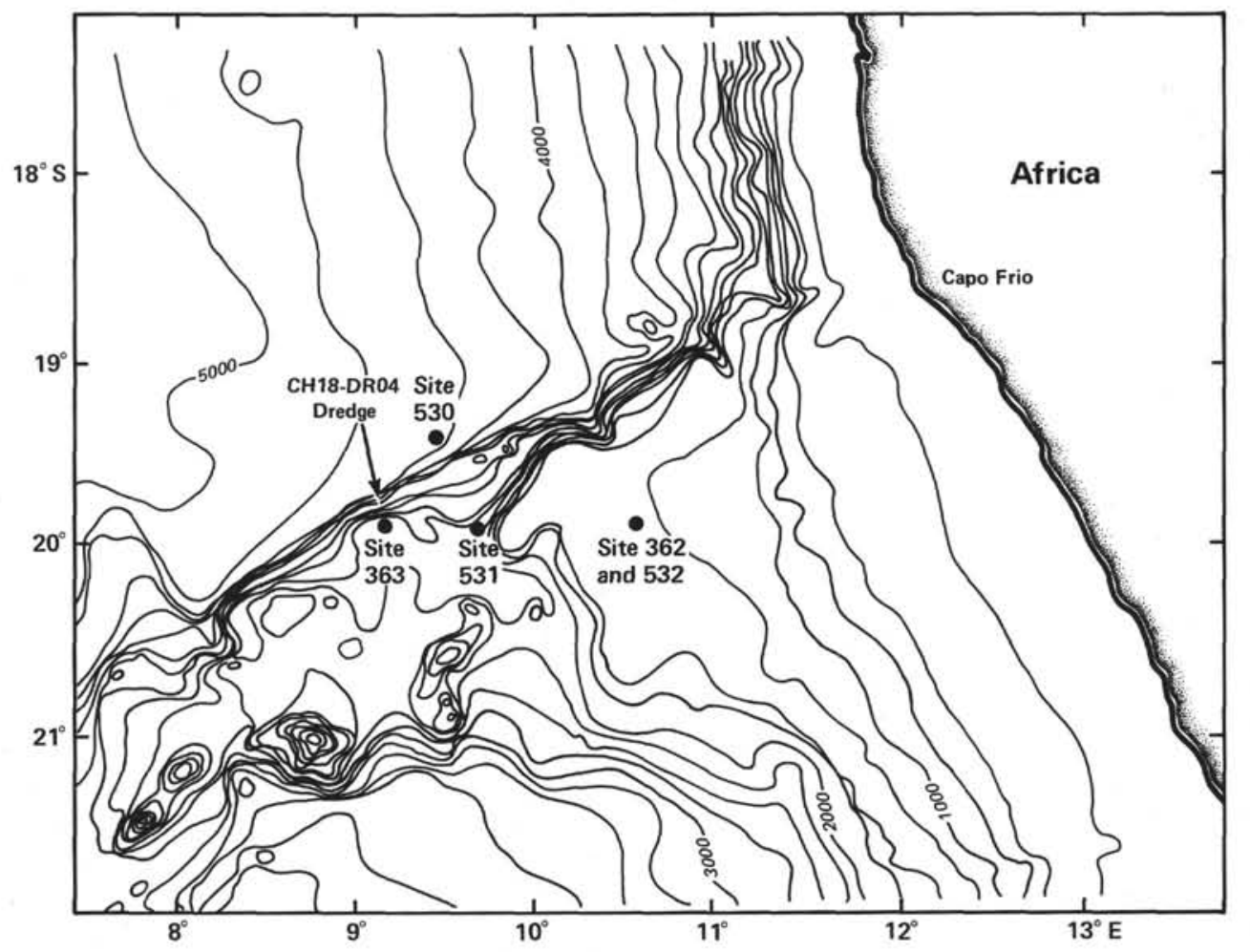

Figure 1. Location map, Site 530.

sential part of biostratigraphical work. In Hole 530A we have found a rather complete sequence of cores from late Albian to the Maestrichtian/Danian boundary, and of course Danian to Recent (see Steinmetz and Stradner, this volume). For establishing the nannofossil zonation of the Cretaceous part of Hole 530A the following biostratigraphical papers of more recent origin have been consulted: Cepek and Hay (1969), Bukry and Bramlette (1970), Manivit (1971), Manivit et al. (1977), Thierstein (1971, 1973), Roth and Thierstein (1972), Roth (1973), Hekel (1973), Thierstein (1974), Bukry (1974), Thierstein (1976), Verbeek (1976), Perch-Nielsen (1977), Sissingh (1977), Perch-Nielsen (1979), Müller (1979), Pflaumann and Cepek (1981), Taylor (1982), Crux (1982).

In the following discussion, each calcareous nannofossil zone is defined and discussed in detail. For the zonal definitions we have followed Pflaumann and Cepek (1981) widely (Fig. 5).

\section{Eiffellithus turriseiffeli Zone}

Authors: Thierstein (1971), emended Roth (1973), emended Verbeek (1977).

Definition: Interval zone from the appearance of Eiffellithus turriseiffeli (Deflandre) to the entry of Lithraphidites acutum Verbeek and Manivit.

Age: Late Albian-Middle Cenomanian

Assigned to interval from Hole $530 \mathrm{~A}-100-4,33 \mathrm{~cm}$ to $105-4,9 \mathrm{~cm}$.

Remarks to biostratigraphy: There is wide agreement regarding the use of the first occurrence of $E$. turriseiffeli to define the lower boundary of this zone (Thierstein, 1971; Roth, 1973; Thierstein, 1974, 1976; Bukry, 1974; Verbeek, 1977; Sissingh, 1977; Perch-Nielsen, 1979;
Pflaumann and Čepek, 1982; and Taylor, 1982). With $L$. alatus absent in the studied samples, $L$. acutum had to be used as marker for the upper boundary, thus following Verbeek's zonal definition.

Wood (1982), by correlating with the entry of Aucellina, was able to show that the beginning of the range of E. turriseiffeli is not at the base of the upper Albian-as shown by Thierstein (1973, fig. 23) and followed by many subsequent nannofossil workers-but well within the substage. Thierstein (1973, fig. 22) has shown the true position of the base of this zone in Bed XI at Copt Point (Folkstone). Taylor (1982) also shows the base of this zone within the upper Albian in the "inflatum"Ammonite zone.

Because of the poor preservation of the core samples from within or between the black shale layers, there is a high degree of uncertainty about the upper boundary of this zone. Since Hayesites albiensis Manivit was not encountered, a subdivision into an upper and lower subzone was not possible. Following Manivit et al. (1977), the extinction of Hayesites albiensis ends the lower $H$. albiensis Subzone. The absence of this species would thus indicate that Sections 100-4 to 105-4 are from the upper subzone, the Prediscosphaera spinosa Subzone (Manivit et al., 1977). Because of the lack of $H$. albianus and other delicate small species, the detailed zonation by Hay (1977) could not be applied in our samples.

Goslin et al. (1974) recognized a prominent discontinuity in seismic profiles (profiles 2, 9, and 11 of their fig. 7) and indicated its extent across the sedimentary basin on top of the Walvis Ridge and into both the Angola and Cape basins. This seismic stratigraphic horizon 
was calibrated by drilling at Site 363 and was found to correspond to a hiatus above upper Albian strata. Such a hiatus may also exist at Site 530, since the presence of the lower part of the L. acutum Zone of middle to late Cenomanian age could not be established by nannofossil analysis.

Perch-Nielsen (1977) has described upper Albian nannofossils from Site 356, São Paulo Plateau. The top of the E. turriseiffeli Zone is not present there, since the Cenomanian and Turonian are missing at that site. A hiatus occurs at a lithological break, in Section 356-41-4, at a depth of about $710 \mathrm{~m}$ below seafloor. Sissingh (1977) distinguishes 26 zones for the Cretaceous interval, the E. turriseiffeli Zone bearing no. 9. Sissingh's zonal definition was not applied, since Microrhabdulus decoratus, the upper boundary marker, is too scarce at Hole 530A.

Remarks to chronostratigraphy: Thierstein (1976, fig. 8, p. 349) assigns an age of 97 m.y. to the base of the E. turriseiffeli Zone and has the Albian/Cenomanian boundary at $94 \mathrm{~m} . \mathrm{y}$. He correlated with the magnetic reversal scales of Larson and Pitman (1972) and Larson and Hilde (1975).

Van Hinte (1976, fig. 2) has the base at 104 m.y., the top at 97.5 m.y., and the Albian/Cenomanian boundary at $100 \mathrm{~m} . \mathrm{y}$.

Roth (1978, fig. 2, p. 734) has the base of this zone at $102 \mathrm{~m} . \mathrm{y}$. and the base of the L. acutum Zone at 94 m.y. In his fig. 3, Roth correlates with magnetic anomalies and has this zone well above the M-0 Anomaly. This zone is named the NC10 Calcareous Nannoplankton Zone and is also identified with the Oceanic Stage "Argusian."

Perch-Nielsen (1977, table 2, p. 702-703) discusses the Correlation of Numerical Time Scale with Coccolith Zones and quotes Douglas and Bukry (1973) to the effect that "there are simply not yet enough data to satisfactorily allow us to assign precise ages to biostratigraphic events."

Ryan et al. (1978) and Proto Decima et al. (1978) have used van Hinte's Cretaceous Time Scale for their Leg 40 reports. From Ryan's table 6 (p. 16) it can be seen that the Magnetic Anomaly M-3 lies about midway in the range of the E. turriseiffeli Zone. Keating and Herrero-Bervera (this volume) shows that no such anomalies are present in the lower core suite of Hole 530A, which would indicate that the basement of Hole 530A was reached above Anomaly M-3-in terms of nannofossil biostratigraphy, in the upper part of the E. turriseiffeli Zone.

In 1979 Perch-Nielsen correlated the E. turriseiffeli biohorizon with $96 \mathrm{~m}$.y. and the $L$. acutum biohorizon with $93 \mathrm{~m} . \mathrm{y}$., both biohorizons being within the normal polarity quiet interval, above Anomaly M- 0 .

In Ness et al. (1980) the corrected age for the Albian/ Cenomanian boundary is given as 96.3 m.y., which age is also taken over by Lowrie and Alvarez, 1981 (p. 396, fig. 3).

\section{Lithraphidites acutum Zone}

Author: Verbeek in Manivit et al. (1977, p. 173)
Definition: Interval from the first occurrence of Lithraphidites acutum Verbeek and Manivit to the first occurrence of Quadrum gartneri Prins and Perch-Nielsen.

Assigned to Sample 530A-100-2, 98-99 cm.

Age: Late Cenomanian to early Turonian

Remarks to biostratigraphy: The only sample in which a few specimens of the rare Lithraphidites acutum could be found also contains Gartnerago obliquum (Stradner). According to Manivit et al. (1977, fig. 1, p. 170) this sample is to be regarded as G. obliquum Subzone, the younger subzone of the $L$. acutum Zone. This subzone straddles the Cenomanian/Turonian boundary.

Manivit (1971), Thierstein (1974, 1976), Verbeek (1976), Hay (1977), Perch-Nielsen (1977), and Roth (1978) use a G. obliquum Zone to define late Cenomanian/early Turonian nannofossil assemblages, with the first occurrence of the name-giving marker fossil indicating the base. Because the overlying $30 \mathrm{~m}$ of sediment is mostly void of nannofossils (Cores 530A-97 to 99), the upper boundary cannot be determined by the first occurrence of $Q$. gartneri or that of Corollithion exiguum or Micula staurophora, all of which were used by different authors to mark the upper boundary of the $G$. obliquum Zone and the $L$. acutum Zone.

Proto Decima et al. (1978) reported that at Sites 363 and 364, the Cenomanian marker L. alatus was not observed; at Site 363 , which is very close to Hole 530A, they consider there to be a gap in sedimentary sequence corresponding to the Cenomanian and Turonian.

Roth $(1978$, fig. 3 , pp. 736,738 ) has the range of Lithraphidites acutum below the first occurrence of the overlying Gartnerago obliquum biohorizon. Correlating with his chart our sample would belong to his $\mathrm{NC12}$ Gartnerago obliquum Zone, or to his Oceanic Stage "Tenerifian," upper part. By correlating with the land record, Roth arrived at an age of Cenomanian to early Turonian for the Tenerifian stage.

Remarks to chronostratigraphy: This nannofossil zone, or rather its younger subzone, straddles the Cenomanian/Turonian boundary, for which (by correlation with paleomagnetic anomalies) the following ages were given: van Hinte (1976, fig. 2): 92 m.y., Thierstein (1976, p. 349): 92 m.y., and Ness et al., (1980, p. 764): 91.7 m.y. For the G. obliquum biohorizon, Thierstein indicates 91 m.y., Roth (1978, fig. 2, p. 734): base 94 m.y; top $92 \mathrm{~m}$.y. for the L. acutum Zone; base $92 \mathrm{~m}$.y., top 90 m.y. for the G. obliquum Zone.

According to Keating and Herrero-Bervera (this volume) this sample lies in the long Cretaceous Quiet Zone 34.

For Sample 530A-100-2, $98-99 \mathrm{~cm}$, an age of 90 to 92 m.y. can be assumed.

\section{Liliasterites angularis Zone}

Authors: Stradner and Steinmetz (this paper)

Definition: Interval from the first occurrence of $\mathrm{Li}$ liasterites angularis Švábenická to the first occurrence of Marthasterites furcatus (Deflandre).

Age: Late Turonian

Type section: Hole 530A, Cores 95 and 96, Section 1 and upper half of Section 2. 
Table 1. Biostratigraphic range chart, Hole 530A, early Danian to late Maestrichtian.

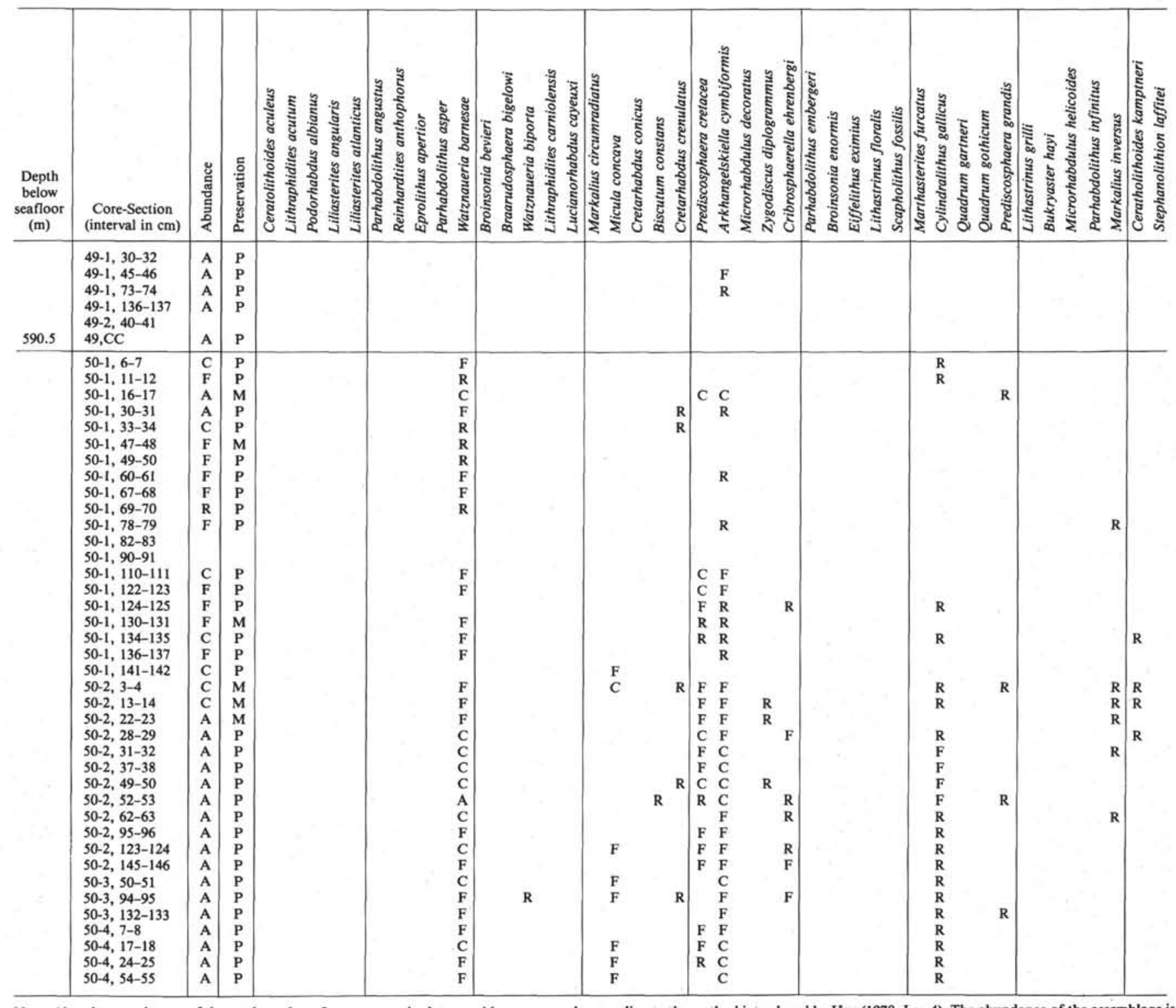

Note: Abundance estimates of the total number of taxa present in the assemblage were made according to the method introduced by Hay (1970, Leg 4). The abundance of the assemblage is estimated by the order of magnitude of its frequency per field of view in the light microscope (oil-immersion objective $100 \times$ ). This is expressed in terms of an exponent to the base ten.

\begin{tabular}{lrlc}
\hline \multicolumn{1}{c}{ Abundance of Specimens } & Logarithm & Designation & Abbr. \\
\hline 10-100 specimens per field of view & +1 & Abundant & A \\
1-10 specimens per field of view & 0 & Common & C \\
Single specimen in 1-10 fields of view & -1 & Few & F \\
Single specimen in 10-100 fields of view & -2 & Rare & R \\
\hline
\end{tabular}

Reference section: Bohemia Czechoslovakia: Kystra near Louny, Jizera formation.

Remarks to biostratigraphy: This new nannofossil zone is described for a late Turonian core sequence from Hole 530A in the Angola Basin by the present authors, and was also found independently in the late Turonian of Kystra, Bohemia, by L. Švábenická, Geological Survey of Czechoslovakia. It can also be found in Tunesia (Perch-Nielsen, pers. comm., 1982). Of the two newly described species of Liliasterites, L. angularis Svábenická and Stradner is the more common and therefore has been chosen as the name-giving marker fossil for this
The overall preservation of nannofossil assemblages was recorded using one of three letter designations (Steinmetz 1979, Leg 49): G = Good preservation. Fossils lack evidence of dissolution or overgrowth. All taxa are easily identified. $\mathbf{M}=$ Moderately good preservation. A majority of the specimens are slightly etched. Fine structures are missing, but no diagnostic changes of form are evident in light microscopy. Rim margins of placoliths are slightly serrate. All taxa may be easily identified. Diversity is normal. $\mathrm{P}=$ Poor preservation. A majority of the specimens are deeply etched. Identity of many centerless and fragmented specimens is questionable. Diversity is low.

new zone. The age assignment is based on the well-documented land section in Bohemia (Čech et al., 1980).

L. angularis in Hole $530 \mathrm{~A}$ has its first occurrence about $11 \mathrm{~m}$ below the first occurrence of $M$. furcatus. At Kystra, Bohemia, L. angularis is to be found in the upper part of the Jizera formation (Iser-Schichten of Krejci, 1869) from 4 to $3 \mathrm{~m}$ below the coprolith horizon which marks the boundary to the overlying Teplize formation (Teplitzer Schichten of Krejci, 1869). Both the upper Jizera and the lower Teplize formation are considered late Turonian (Cech et al., 1980). The upper boundary of the $L$. angularis Zone is marked by the first oc- 
Table 1. (Continued).

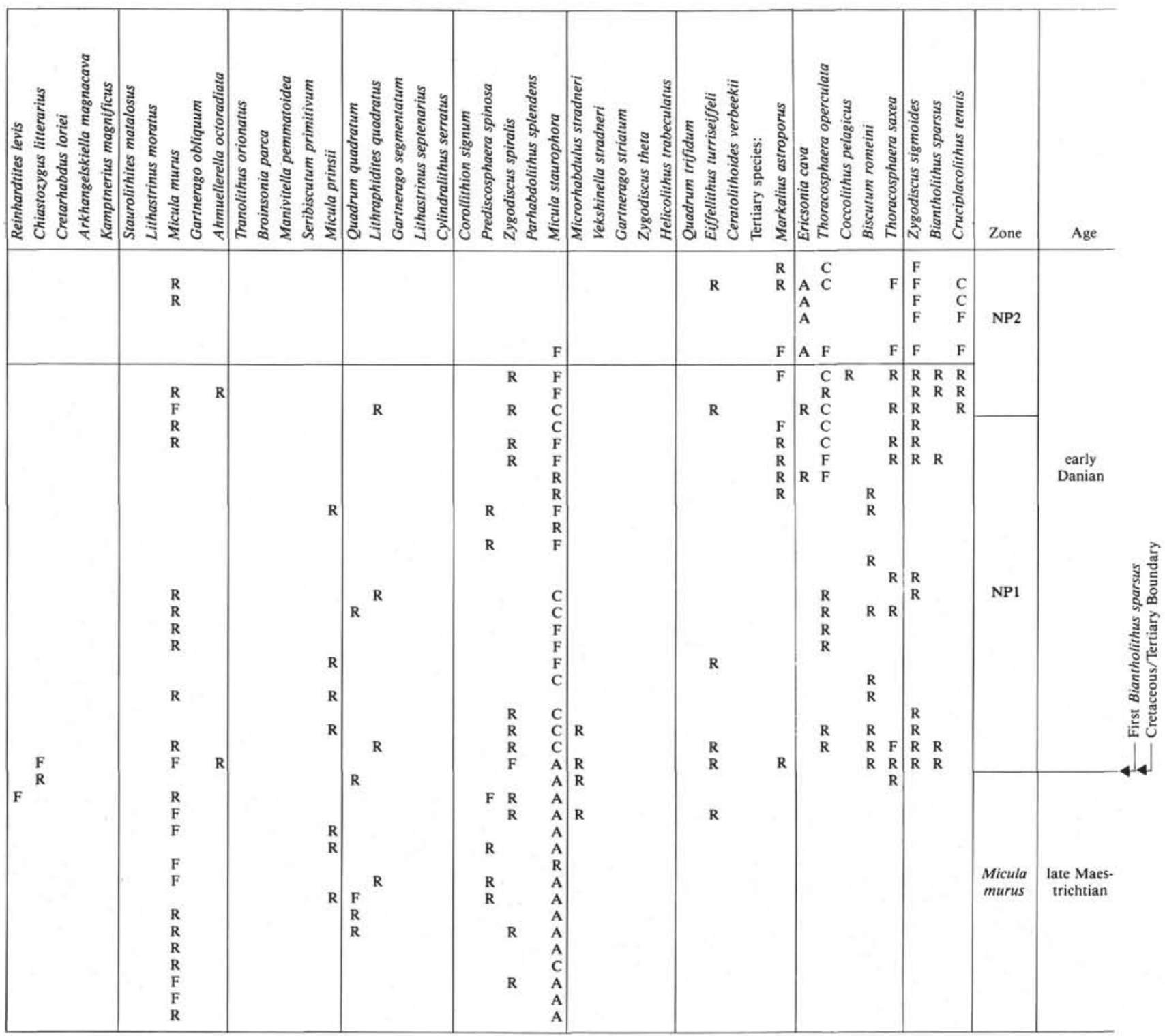

currence of $M$. furcatus (Deflandre), which according to Thierstein (1976), Verbeek (1977), Perch-Nielsen (1977), Roth (1978), Perch-Nielsen (1979), and Pflaumann and Cepek (1982) has its first occurrence approximately coinciding in time with the Turonian/Coniacian boundary. Manivit et al. (1977) place the base of $M$. furcatus somewhat above the Turonian/Coniacian boundary.

The stratigraphic range of the $L$. angularis Zone is, as far as can be judged from the Hole 530A cores, almost identical with the range of the Eiffellithus eximius Zone sensu (Manivit et al., 1977, p. 175). Their definition, however, was not applied here, since the term "Eiffellithus eximius Zone" refers to a different definition and range (see Bukry and Bramlette, 1970; Perch-Nielsen, 1977).

Remarks to chronostratigraphy: The $L$. angularis Zone lies below the Turonian/Coniacian boundary, for which the following ages were given by correlation with paleomagnetic anomalies: van Hinte (1976): 86 m.y.; Thier- stein (1976): 87 m.y.; Ryan et al. (1978): 86 m.y.; Roth (1978): 86 m.y.; Ness et al. (1980): 89.2 m.y.; Lowrie and Alvarez (1981): 89.2 m.y.

Keating and Herrero-Bervera (this volume) place the cores of this zone in the long Cretaceous Quiet Zone 34.

\section{Marthasterites furcatus Zone}

Authors: Čepek and Hay (1969), emended PerchNielsen (1977).

Definition: Interval from the first occurrence of Marthasterites furcatus (Deflandre) to the first occurrence of Broinsonia parca (Stradner).

Age: Coniacian and Santonian, including the lowest part of the lower Campanian.

Assigned to interval from Cores 530A-79-1, 141-142 $\mathrm{cm}$ to $530 \mathrm{~A}-94-2,87-89 \mathrm{~cm}$.

Remarks to biostratigraphy: Verbeek (1976) has remarked that the entry of $M$. furcatus is a well-known worldwide event. At Site 530 in the Angola Basin, this 
Table 2. Biostratigraphic range chart, Hole 530A, late Maestrichtian to late Campanian. (See note, Table 1.)

\begin{tabular}{|c|c|c|c|c|c|c|c|c|c|c|c|c|}
\hline $\begin{array}{c}\text { Depth } \\
\text { below } \\
\text { seafloor } \\
\text { (m) }\end{array}$ & $\begin{array}{c}\text { Core-Section } \\
\text { (interval in cm) }\end{array}$ & 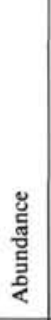 & 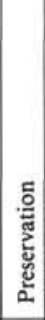 & 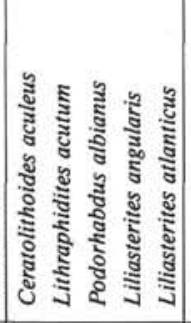 & 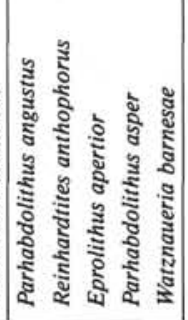 & 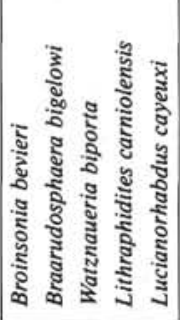 & 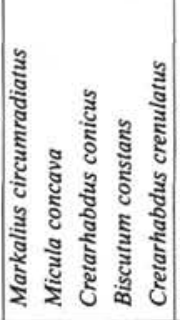 & 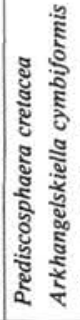 &  &  & 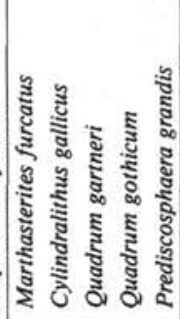 & 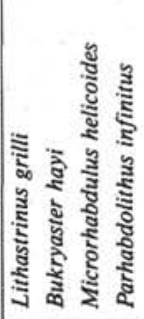 \\
\hline 600.0 & $\begin{array}{l}50-4,81-82 \\
50, C C\end{array}$ & $\mathrm{~A}$ & $\mathbf{P}$ & & & & & R F & & & & \\
\hline 609.5 & $\begin{array}{l}51-1,90-91 \\
51-2,38-39 \\
51-5,43-44 \\
51, C C\end{array}$ & $\begin{array}{l}\mathrm{A} \\
\mathrm{A} \\
\mathrm{A} \\
\mathrm{A}\end{array}$ & \begin{tabular}{|l|}
$\mathrm{P}$ \\
$\mathrm{P}$ \\
$\mathrm{P}$ \\
$\mathrm{P}$ \\
\end{tabular} & $\begin{array}{l}\mathrm{R} \\
\mathrm{R}\end{array}$ & \begin{tabular}{l|}
$\mathrm{F}$ \\
$\mathrm{C}$ \\
$\mathrm{C}$ \\
$\mathrm{C}$
\end{tabular} & & $\begin{array}{l}\mathrm{F} \\
\mathrm{F} \\
\mathrm{C} \\
\mathrm{F}\end{array}$ & \begin{tabular}{|ll}
$\mathrm{R}$ & $\mathrm{F}$ \\
$\mathrm{F}$ & $\mathrm{C}$ \\
$\mathrm{R}$ & $\mathrm{R}$ \\
$\mathrm{R}$ & $\mathrm{R}$ \\
\end{tabular} & C $\quad \mathrm{R}$ & $R$ & & - \\
\hline 619.0 & $\begin{array}{l}52-1,50-51 \\
52, \mathrm{CC}\end{array}$ & A & $\mathrm{P}$ & R & C & & & R & & & & \\
\hline 628.5 & $\begin{array}{l}53-1,95-96 \\
53-2,64-65 \\
53, \mathrm{CC}\end{array}$ & $\begin{array}{l}\mathrm{A} \\
\mathrm{C} \\
\mathrm{A}\end{array}$ & $\begin{array}{l}\mathrm{P} \\
\mathrm{P} \\
\mathrm{P} \\
\end{array}$ & R & $\begin{array}{l}\mathrm{R} \\
\mathrm{R}\end{array}$ & & & $\mathbf{R}$ & & & & \\
\hline 638.0 & $\begin{array}{l}54-1,105-106 \\
54, C C\end{array}$ & $\begin{array}{l}\mathrm{A} \\
\mathrm{A}\end{array}$ & \begin{tabular}{l|}
$\mathrm{P}$ \\
$\mathrm{P}$ \\
\end{tabular} & R & $\begin{array}{l}\mathbf{R} \\
\mathrm{R} \\
\end{array}$ & $\mathbf{R}$ & & $\begin{array}{|ll|}R & F \\
R & \\
\end{array}$ & $\mathbf{R}$ & & & \\
\hline 647.5 & $\begin{array}{l}55-1,17-18 \\
55-1,143-144 \\
55-2,80-81 \\
55-3,39-40 \\
55-4,77-78 \\
55-4,82-83 \\
55-5,125-126 \\
55, C C\end{array}$ & \begin{tabular}{l|}
$\mathrm{A}$ \\
$\mathrm{A}$ \\
$\mathrm{A}$ \\
$\mathrm{A}$ \\
$\mathrm{A}$ \\
$\mathrm{A}$ \\
$\mathrm{A}$ \\
$\mathrm{A}$
\end{tabular} & \begin{tabular}{|l|}
$\mathrm{P}$ \\
$\mathrm{P}$ \\
$\mathrm{P}$ \\
$\mathrm{P}$ \\
$\mathrm{P}$ \\
$\mathrm{P}$ \\
$\mathrm{P}$ \\
$\mathrm{P}$
\end{tabular} & \begin{tabular}{|l|}
$R$ \\
$R$ \\
$R$ \\
$R$
\end{tabular} & \begin{tabular}{l|}
$\mathrm{F}$ \\
$\mathrm{R}$ \\
$\mathrm{C}$ \\
$\mathrm{C}$ \\
$\mathrm{F}$ \\
$\mathrm{C}$ \\
$\mathrm{F}$ \\
$\mathrm{F}$
\end{tabular} & & $\mathbf{R}$ & $\begin{array}{ll}\mathrm{R} & \mathrm{R} \\
\mathrm{R} & \\
\mathrm{R} & \\
\end{array}$ & $\begin{array}{ll} & \mathrm{F} \\
\mathrm{R} & \mathrm{R} \\
\mathrm{R} & \end{array}$ & & $\begin{array}{l}\mathrm{R} \\
\mathrm{R} \\
\mathrm{R} \\
\mathrm{R} \\
\mathrm{F} \\
\mathrm{F} \\
\mathrm{F} \\
\mathrm{F}\end{array}$ & \\
\hline 657.0 & $\begin{array}{l}56-1,39-40 \\
56-1,102-103 \\
56-2,17-18 \\
56-2,70-71 \\
56, \mathrm{CC}\end{array}$ & \begin{tabular}{l|} 
A \\
A \\
A \\
A \\
C
\end{tabular} & \begin{tabular}{|l|}
$\mathrm{P}$ \\
$\mathrm{P}$ \\
$\mathrm{P}$ \\
$\mathrm{P}$ \\
$\mathrm{P}$
\end{tabular} & R & \begin{tabular}{l|}
$\mathrm{F}$ \\
$\mathrm{C}$ \\
$\mathrm{C}$ \\
$\mathrm{C}$ \\
$\mathrm{F}$
\end{tabular} & $\mathbf{R}$ & & $\begin{array}{ll}\mathrm{R} & \mathrm{R} \\
\mathrm{R} & \end{array}$ & & & $\begin{array}{l}\mathrm{F} \\
\mathrm{F} \\
\mathrm{C} \\
\mathrm{C} \\
\mathrm{F}\end{array}$ & \\
\hline 666.5 & $\begin{array}{l}57-1,43-44 \\
57-1,94-95 \\
57-2,65-66 \\
57-2,80-81 \\
57-2,86-87 \\
57-2, C C\end{array}$ & \begin{tabular}{l|}
$\mathrm{F}$ \\
$\mathrm{R}$ \\
$\mathrm{C}$ \\
$\mathrm{A}$ \\
$\mathrm{A}$ \\
$\mathrm{A}$
\end{tabular} & \begin{tabular}{|l|}
$\mathrm{P}$ \\
$\mathrm{P}$ \\
$\mathrm{M}$ \\
$\mathrm{P}$ \\
$\mathrm{P}$ \\
$\mathrm{P}$
\end{tabular} & $\begin{array}{l}\mathrm{R} \\
\mathrm{R} \\
\mathrm{R}\end{array}$ & $\begin{array}{l}\text { R } \\
\text { F } \\
\text { C } \\
\text { F } \\
\text { F }\end{array}$ & & $\begin{array}{l}\text { F } \\
\text { R } \\
\text { C } \\
\text { A } \\
\text { C }\end{array}$ & $R$ & $\mathbf{R}$ & & $\begin{array}{l}R \\
R \\
R \\
F\end{array}$ & $\begin{array}{l}\mathrm{R} \\
\mathrm{R}\end{array}$ \\
\hline 676.0 & $\begin{array}{l}58-1,12-13 \\
58-1,90-91 \\
58-1,121-122 \\
58, \mathrm{CC}\end{array}$ & \begin{tabular}{l|}
$\mathrm{A}$ \\
$\mathrm{C}$ \\
$\mathrm{A}$ \\
$\mathrm{A}$
\end{tabular} & \begin{tabular}{|l|}
$\mathrm{P}$ \\
$\mathrm{P}$ \\
$\mathrm{P}$ \\
$\mathrm{P}$ \\
\end{tabular} & $\mathrm{F}$ & $\begin{array}{l}\text { C } \\
\text { C } \\
\text { C } \\
\text { F }\end{array}$ & & $\begin{array}{ll} & \mathrm{R} \\
\mathrm{C} & \mathrm{R} \\
\mathrm{A} & \mathrm{R} \\
\mathrm{C} & \end{array}$ & $\begin{array}{l}\mathrm{F} \\
\mathrm{R}\end{array}$ & $\begin{array}{l}\mathrm{F} \\
\mathrm{R} \\
\mathrm{R} \\
\mathrm{R}\end{array}$ & & $\begin{array}{l}\mathrm{C} \\
\mathrm{R} \\
\mathrm{F} \\
\mathrm{F}\end{array}$ & \\
\hline 685.5 & $\begin{array}{l}59-1,7-8 \\
59-1,52-53 \\
59-1,142-143 \\
59-2,44-45 \\
59-2,104-105 \\
59, \mathrm{CC}\end{array}$ & \begin{tabular}{l|}
$\mathrm{C}$ \\
$\mathrm{A}$ \\
$\mathrm{A}$ \\
$\mathrm{C}$ \\
$\mathrm{C}$ \\
$\mathrm{C}$ \\
\end{tabular} & \begin{tabular}{|c|}
$\mathrm{P}$ \\
$\mathrm{P}$ \\
$\mathrm{P}$ \\
$\mathrm{P}$ \\
$\mathrm{M}$ \\
$\mathrm{P}$ \\
\end{tabular} & $\begin{array}{l}\mathrm{R} \\
\mathrm{R} \\
\mathrm{R} \\
\mathrm{R}\end{array}$ & $\begin{array}{l}\text { F } \\
\text { C } \\
\text { A } \\
\text { C } \\
\text { F } \\
\text { F }\end{array}$ & & $\begin{array}{l}\mathrm{C} \\
\mathrm{C} \\
\mathrm{C} \\
\mathrm{C} \\
\mathrm{C} \\
\mathrm{C}\end{array}$ & \begin{tabular}{|ll}
$\mathbf{R}$ & \\
& \\
& $R$ \\
$R$ & $R$ \\
$F$ & $R$ \\
\end{tabular} & $\begin{array}{ll} & \mathrm{R} \\
\mathrm{R} & \mathrm{F} \\
\mathrm{R} & \mathrm{F} \\
\mathrm{R} & \mathrm{R} \\
& \mathrm{R} \\
& \mathrm{R} \\
\mathrm{R} & \mathrm{R} \\
\end{array}$ & $R$ & $\begin{array}{l}\mathrm{F} \\
\mathrm{R} \\
\mathrm{R} \\
\mathrm{R}\end{array}$ & R \\
\hline & $\begin{array}{l}60-1,87-88 \\
60-1,132-133 \\
60-2,20-21\end{array}$ & $\begin{array}{l}\mathrm{A} \\
\mathrm{A} \\
\mathrm{A}\end{array}$ & \begin{tabular}{|l|}
$\mathrm{P}$ \\
$\mathrm{P}$ \\
$\mathrm{P}$
\end{tabular} & $\begin{array}{l}\mathrm{F} \\
\mathrm{R} \\
\mathrm{R}\end{array}$ & $\begin{array}{l}\mathrm{F} \\
\mathrm{F} \\
\mathrm{C}\end{array}$ & & $\begin{array}{l}\text { F } \\
\text { C } \\
\text { C }\end{array}$ & & $\begin{array}{ll}R & R \\
R & R\end{array}$ & & $\begin{array}{l}\mathrm{F} \\
\mathrm{F} \\
\mathrm{F}\end{array}$ & R \\
\hline
\end{tabular}

species is common in many samples. Its first occurrence is overlapped by the range of the older Liliasterites angularis and by $L$. atlanticus. Crux $(1982$, p. 87$)$ claims that in Great Britain M. furcatus is found well below the Coniacian; he has included specimens which are now assigned to the older genus Liliasterites in the species Marthasterites furcatus sensu stricto.

Perch-Nielsen (1977) has emended the M. furcatus Zone and introduced the first occurrence of $B$. parca as upper zonal boundary. Sissingh (1977) used a different definition for this zone (partial range zone from the first occurrence of $M$. furcatus to the first occurrence of $M i$ cula ex. gr. staurophora [Gardet] Bramlette and Martini). At Site 530 the first specimens of Quadrum gartneri
Prins and Perch-Nielsen were found in Sample 94-1, 72$73 \mathrm{~cm}, 150 \mathrm{~cm}$ above the first Marthasterites furcatus; the first Micula staurophora (Gardet) in Sample 92-1, $64-65 \mathrm{~cm}$, was found $21 \mathrm{~m}$ above the first $M$. furcatus. This would support the range sequence given by Sissingh (1977) against that of many other authors who have the first occurrences of $M$. furcatus and Micula staurophora in reversed sequence. It is difficult, however, to decide how far syndepositional solution of nannofossils in the South Atlantic is the cause for our first occurrence data.

Ryan et al. (1978), Proto Decima et al. (1978), and Perch-Nielsen (1979) found the Broinsonia parca biohorizon above Magnetic Anomaly 34. With the data of 
Table 2. (Continued).

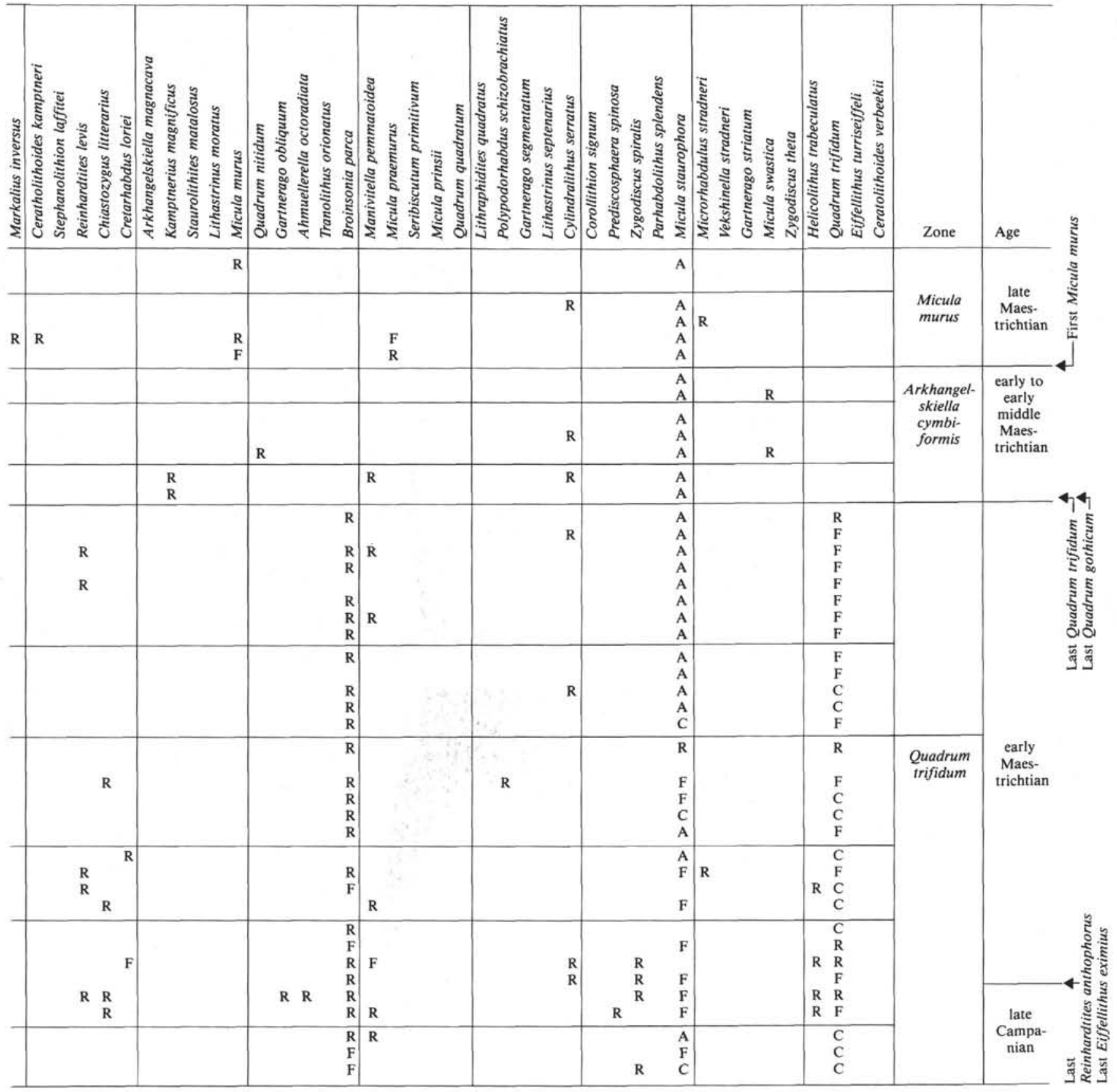

Site 530 we are in good agreement with Perch-Nielsen (1979) and have the $B$. parca biohorizon higher than the Santonian/Campanian boundary. This is in good agreement with paleomagnetic data (see below) and is the reason why we have added the lowermost Campanian to the Coniacian and Santonian range of this zone.

Roth (1978, fig. 2, p. 734) subdivides the interval between the $M$. furcatus and $B$. parca biohorizons into three zones (NC15-NC17) using the first occurrences of B. lacunosa and of Tetralithus obscurus, Micula concava, and Lithraphidites helicoides, respectively. Since all of these species except $M$. concava are rare at Site 530 , this subdivision was not applicable.

Proto Decima et al. (1978) in their zonation for the Cretaceous of Sites 363 and 364 in the South Atlantic have used the same biohorizons for this zone as PerchNielsen (1977) did in the South Atlantic for Sites 356 and 357.

Remarks to chronostratigraphy: According to Keating and Herrero-Bervera (this volume) all cores assigned to this zone lie within the long Normal Polarity Quiet Interval 34. 
Table 3. Biostratigraphic range chart, Hole 530A, late Campanian to early Campanian. (See note, Table 1.)

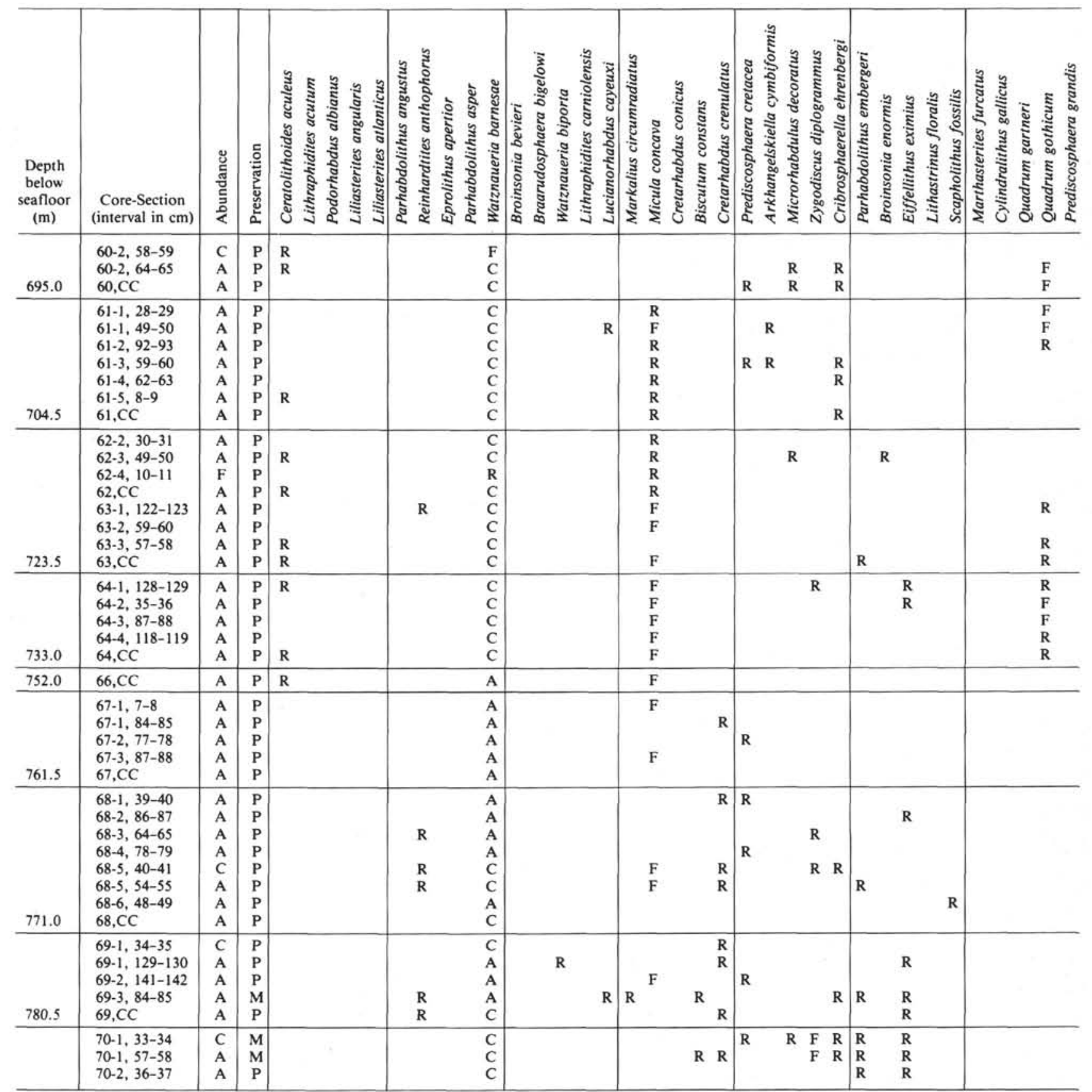

In van Hinte's Cretaceous Time Scale (1976) the Marthasterites furcatus biohorizon is at 84 m.y., above the Santonian/Coniacian boundary at $86 \mathrm{~m} . \mathrm{y}$. , and the Broinsonia parca biohorizon is at $78 \mathrm{~m} . y$. , identical with the Santonian/Campanian boundary.

Thierstein (1976, fig. 8, p. 349) has the base of the $M$. furcatus Zone at $87 \mathrm{~m}$.y. and the base of $B$. parca at 82 m.y., below the top of Magnetic Anomaly 34 which he dates at 80 m.y. In LaBrecque et al. (1977, fig. 3, p. 333) the top of the long Normal Polarity Quiet Interval 34 is dated 79.65 m.y., slightly above the Santonian/ Campanian boundary. Roth (1978, fig. 3, p. 736) has the $M$. furcatus Zone ranging from 86 to $80 \mathrm{~m}$.y., that is from his Zones NC15-NC17, covering the entire How- landian Oceanic Stage. The $B$. parca horizon is identical with the top of Anomaly 34 and the 80 m.y. mark there.

Ryan et al. (1978) and Proto Decima et al. (1978) have the $M$. furcatus Zone beginning in the higher Coniacian at $84 \mathrm{~m} . \mathrm{y}$. and ending at $77 \mathrm{~m} . \mathrm{y}$. - that is, more than halfway between Magnetic Anomalies 33 and 34 . In other words, they place the $B$. parca horizon at 78 m.y., well above the top of the long Normal Polarity Quiet Zone at $80 \mathrm{~m} . \mathrm{y}$.

In Perch-Nielsen (1979, fig. 2, p. 227) the two biohorizons embracing the $M$. furcatus Zone are correlated with 87 m.y. and 81 m.y., the upper boundary being somewhat below the top of Magnetic Anomaly 34 at 80 m.y. 
Table 3. (Continued).

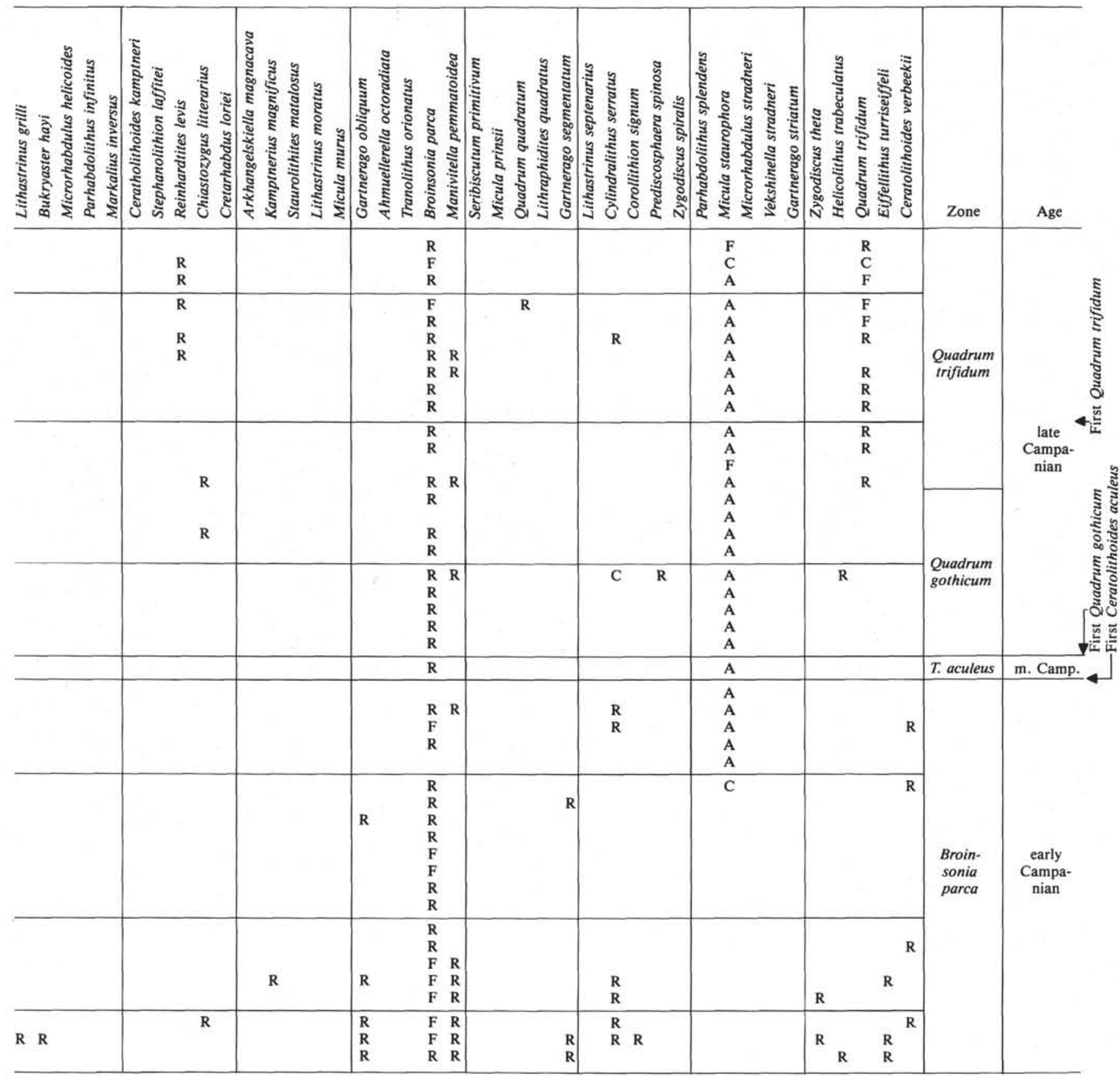

Ness et al. (1980, table 1, p. 764) assigned a corrected age of 84.1 m.y. to the Santonian/Campanian boundary and $89.2 \mathrm{~m}$.y. to the Turonian/Coniacian boundary. Thus, the $M$. furcatus Zone spans a long time interval of about 5-6 m.y. Lowrie and Alvarez use the revised dates by Ness et al. (1980, p. 396, fig. 3).

\section{Reinhardtites anthophorus Zone}

Author: Sissingh (1977).

Definition: Interval from the first occurrence of Reinhardtites anthophorus (Deflandre) Perch-Nielsen to the first occurrence of Lucianorhabdus cayeuxi Deflandre.
Age: According to Sissingh (1977), late part of early Santonian; according to Crux (1982), Santonian.

Assigned to interval from: Sample 530A-78-6, 46-47 $\mathrm{cm}$ to $530 \mathrm{~A}-80-3,18-19 \mathrm{~cm}$.

Remarks to biostratigraphy: This zone, which at Site 530 straddles the Santonian/Campanian boundary, is defined by two species which are rare in the Angola $\mathrm{Ba}$ sin and therefore not reliable. The first occurrences actually might be much lower, but were not discovered. In our charts this zone can be proven in the upper part of the Marthasterites furcatus Zone and the lowest part of the Eiffellithus eximius Zone (sensu Perch-Nielsen, 1977), 
Table 4. Biostratigraphic range chart, Hole 530A, early Campanian. (See note, Table 1.)

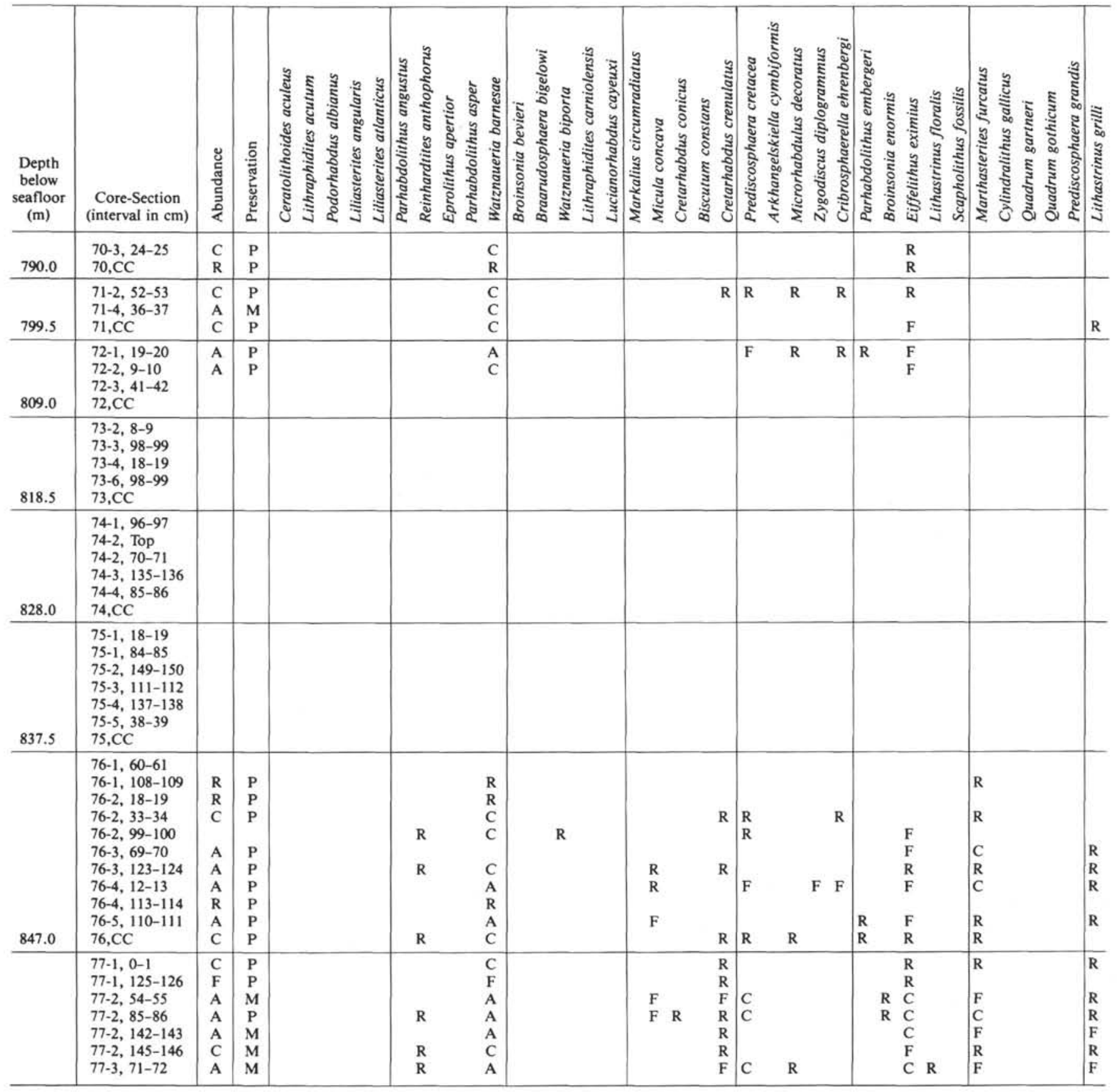

since $L$. cayeuxi was not found any earlier. It is mentioned here merely as subject for discussion.

The first one to apply this zonal name to a Late Cretaceous nannofossil assemblage at Site 111 in the northern Atlantic was Perch-Nielsen (1972, p. 1106). No details were given other than the presence of $R$. anthophorus.

Sissingh (1977, fig. 12, p. 52) has $R$. anthophorus ranging from the early Santonian to the upper Campanian (his nannofossil Zones 15-22b); Lucianorhabdus cayeuxi from late Santonian to early Maestrichtian (Zones 16-23a).
In Perch-Nielsen (1979, charts, figs. 2 and 17) both species are given the same vertical distribution as in Sissingh (1977), with Lucianorhabdus cayeuxi ranging up to the top of the Maestrichtian.

Crux (1982) determined the $R$. anthophorus Zone in the early Santonian ("coranguinum") macrofossil Zone of Great Britain.

Remarks to chronostratigraphy: Because of only scanty occurrences of the boundary fossils, not even approximate ages can be given for this tentative zone. At Site 530 it seems to straddle the Santonian/Campanian 
Table 4. (Continued).



boundary, the age of which was discussed in connection with the previous zone.

\section{Eiffellithus eximius Zone}

Authors: Bukry and Bramlette (1970), emended PerchNielsen (1977).

Definition: Interval from the first occurrence of Broinsonia parca (Stradner) to the last occurrence of Marthasterites furcatus (Deflandre).

Age: Early Campanian

Assigned to interval from Sample 530A-76-1, 108$109 \mathrm{~cm}$ to Sample 530A-78,CC.

Remarks to biostratigraphy: This nannofossil zone is separated from the overlying $B$. parca Zone by a barren (and therefore unzoned) interval of about $30 \mathrm{~m}$. Between the two boundary-forming biohorizons lies the first occurrence of Bukryaster hayi, at Site 530 in Sample 530A-77-2, 85-86 cm. In Perch-Nielsen (1979, fig. 2, p. 227) the range of $B$. hayi lies in the early Campanian within Sissingh's Zones 18b and 19a. At Site 530, however, $B$. hayi also was found in the lower part of the overlying Broinsonia parca Zone after the extinction of Marthasterites furcatus. This high occurrence of $B$. hayi at Sample 530A-70-1, 57-58 cm might be the result of reworking.

Before 1979 the lower boundary of this zone was positioned within the late Santonian (Perch-Nielsen, 1977) or at the Santonian/Campanian boundary (Thierstein, 
Table 5. Biostratigraphic range chart, Hole 530A, early Campanian to late Santonian. (See note, Table 1.)



1976; Sissingh, 1977). Based on paleomagnetic data by Keating and Herrero-Bervera (this volume) we follow the views of Perch-Nielsen (1979), Pflaumann and Cepek (1982), and Crux (1982) and place the Broinsonia parca biohorizon in the early Campanian. The upper part of the range of $M$. furcatus, which marks the top of this zone by its extinction, possibly is curtailed by the barren interval from $530 \mathrm{~A}-72-2,10 \mathrm{~cm}$ to $530 \mathrm{~A}-76-1,108 \mathrm{~cm}$.

Bukry and Bramlette (1970) have their E. augustus Zone, which they termed Campanian, ranging from the first occurrence of $B$. parca to the last occurrence of $E$. augustus. Roth (1973) used the same horizons and substituted the older name $E$. eximius for syn. $E$. augustus (of Bukry). Age is early Campanian. Perch-Nielsen (1977) emended this zone by taking the last occurrence of $M$. furcatus as upper boundary and reported this zone from Site 357 in the South Atlantic.
Proto Decima et al. (1978) also reported this zone from Sites 363 and 364 and noted that the last occurrence of $E$. eximius is above the first occurrence of $T e$ tralithus trifidus. Therefore they preferred the first occurrence of T. trifidus as upper biohorizon for this zone.

In Perch-Nielsen (1979) the zone between the two biohorizons of $B$. parca and $M$. furcatus comprises only a very short time interval in the upper part of Sissingh's nannofossil Zone $18 \mathrm{~b}$.

Hattner and Wise (1980) have introduced their new subspecies Broinsonia parca constricta into the zonal definition. Since the genus Broinsonia has an astounding line of evolution within the Campanian (see Crux 1982 , p. $95-98$ and our discussion on $B$. parca in the notes on nannoplankton paleontology) the usefulness of different subspecies in Broinsonia biostratigraphy awaits further demonstration. 
Table 5. (Continued).

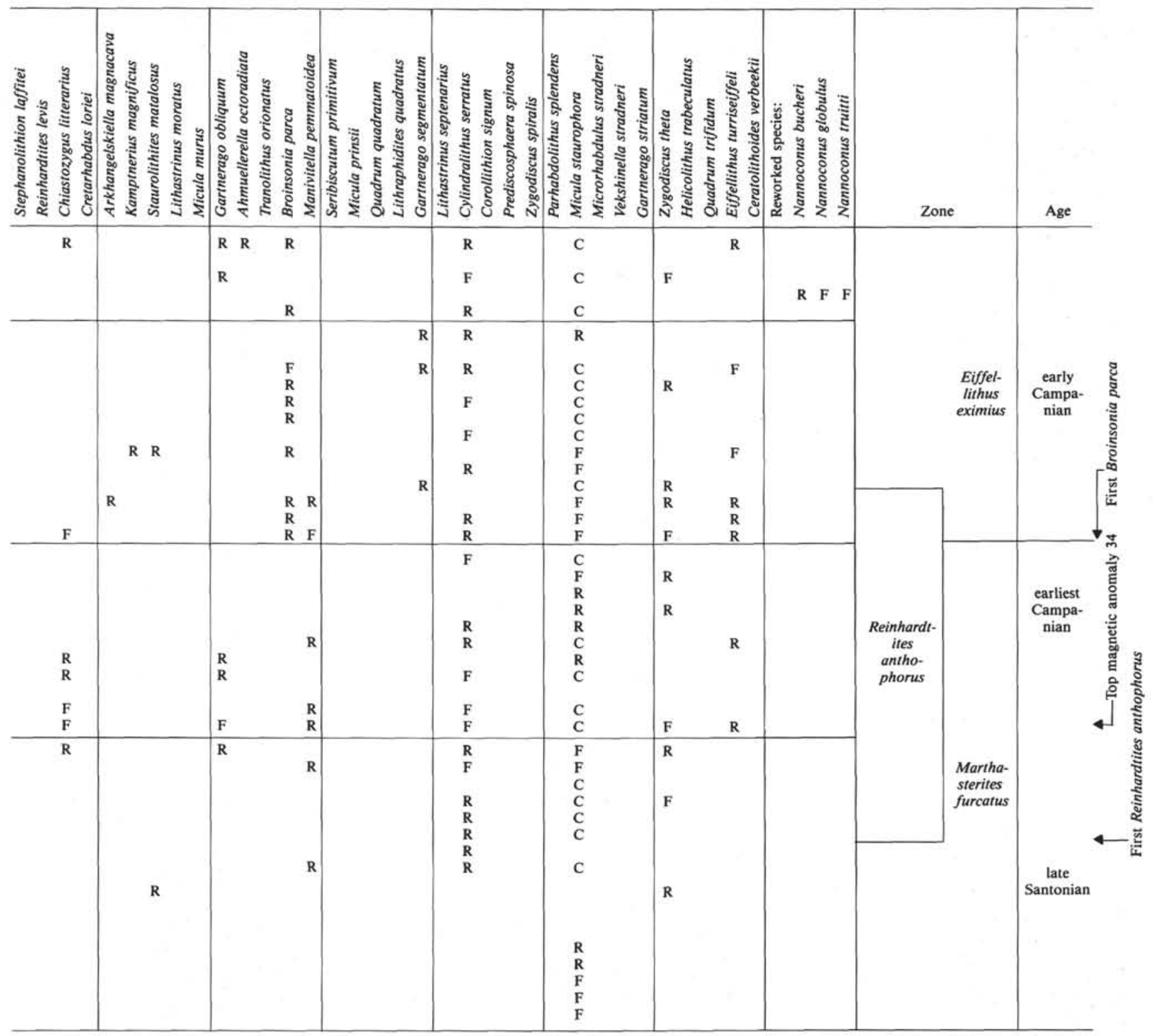

Remarks to chronostratigraphy: The $E$. eximius Zone at Site 530 starts about $9 \mathrm{~m}$ above the paleomagnetic Anomaly 34, in the early Campanian. The age of the Santonian/Campanian boundary was already discussed in the remarks to the previous zone. We find it difficult to assign an age to the top of this zone as well as to the bottom of the overlying $B$. parca Zone since these are separated by a $30 \mathrm{~m}$ barren interval.

\section{Broinsonia parca Zone}

Author: Perch-Nielsen (1977).

Definition: Interval from the last occurrence of Marthasterites furcatus (Deflandre) to the first occurrence of Ceratolithoides aculeus (Stradner).

Age: Early Campanian.

Assigned to interval from Sample 530A-67-1, 7-8 cm to Sample 530A-72-1, 9-10 cm.
Remarks to biostratigraphy: The zonal definition of this zone does not use the name-giving species as boundary marker, though it lies within its range. PerchNielsen (1977) has described this zone from Site 357 in the South Atlantic.

Verbeek (1976), Thierstein (1976), and Verbeek (1977) have been using a zone bearing the same name, starting with the first occurrence of Broinsonia parca and ending with the first occurrence of Tetralithus aculeus.

Sissingh (1977) divides the interval between the $B$. parca and the Ceratolithoides (= Tetralithus) aculeus biohorizons into two parts based on the extinction of M. furcatus and calls them Aspidolithus parcus and Calculites ovalis zones (numbers 18 and 19). Age is early Campanian.

Roth (1973) and Müller (1979) have used a different concept for their B. parca Zones, i.e., the interval from 
Table 6. Biostratigraphic range chart, Hole 530A, late Santonian to late Turonian. (See note, Table 1.)

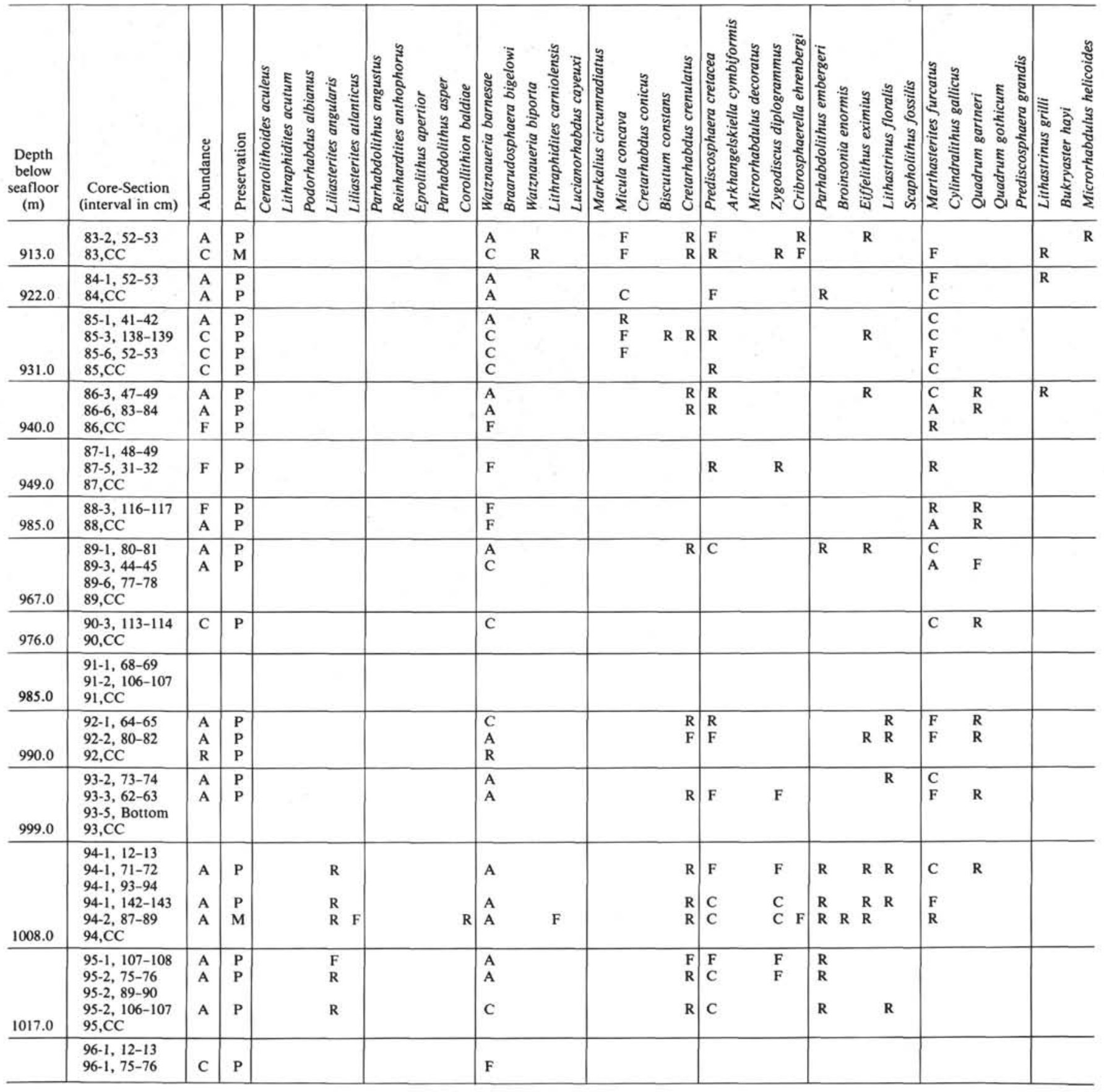

the last occurrence of Eiffellithus eximius to the first occurrence of T. trifidus. Verbeek (1977), however, found that $E$. eximius disappeared later than the entry of $T$. trifidus, which is also the case at Site 530. There the entry of $Q$. trifidum (=T. trifidus) is in Sample 530A$62, C C$ and the extinction of E. eximius at Sample 530A$59-2,44-45 \mathrm{~cm}$. Thus the zonal concept using these biohorizons is not applicable any more.

Crux (1982) has emended Sissingh's definition by using the interval from the $B$. parca biohorizon to the first occurrence of Prediscosphaera stoveri. The reason for extending Sissingh's zone was the absence of other zonal markers in Great Britain.
Remarks to chronostratigraphy: According to paleomagnetic stratigraphy by Keating and Herrero-Bervera (this volume), both major parts of the $B$. parca and the underlying $E$. eximius zones fall between the normal Magnetic Anomalies 33 and 34 into a reversed interval. Actually this reversed interval between Cores 69 and 80 is interspersed with short normal intervals between Cores 72 and 75 . In this latter mixed interval no nannofossil assemblages were found, and therefore these cores cannot be assigned to either of these zones. Perch-Nielsen (1977, fig. 11, p. 116) correlated the magnetic stratigraphy at the Gubbio section, Italy, with magnetic profiles in the South Atlantic (L-DGO, profiles C1102 and 3101). 
Table 6. (Continued).

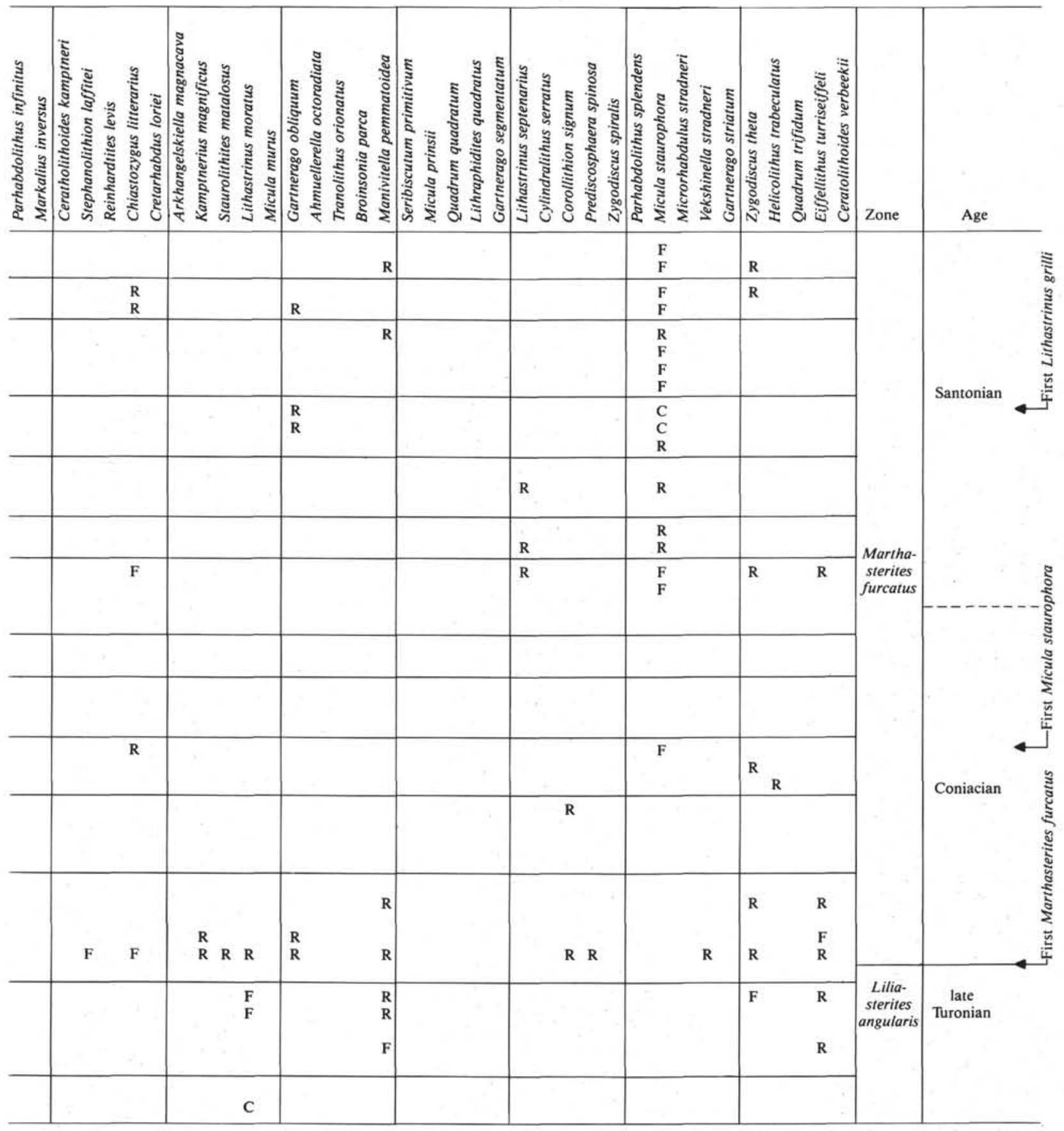

The lower Campanian there lies between Anomalies 33 and 34 and is assigned an age of 73 to 78 m.y.

Roth (1978, fig. 3, p. 736) has the T. aculeus biohorizon in the lower part of Anomaly 33 at 77 m.y.

Ryan et al. (1978, table 6, p. 16) are using different biohorizons in their chart, which are not directly correlatable with ours.

Perch-Nielsen (1979, fig. 2, p. 227) has the M. furcatus extinction at $80 \mathrm{~m}$.y. (top of Sissingh Zone $18 \mathrm{~b}$ ) and the first occurrence of C. aculeus (base of Zone 20) at 77 m.y. On fig. 5, p. 235 in her column A (magnetic anomaly pattern derived from ocean floor) this interval is corresponding to the reversed magnetic interval be- tween 33 and 34 and includes also the lowest part of the normal Anomaly 33.

In Ness et al. (1980, table 1, p. 764) and Lowrie and Alvarez (1981) the Campanian lasts 11.8 m.y., from 72.3 to 84.1 m.y. According to their boundary ages, a slightly older time span than that on the previously discussed charts would have to be assumed for the two early Campanian nannofossil zones, the $E$. eximius Zone and the $B$. parca Zone, about from 78 to 83 m.y.

\section{Ceratolithoides aculeus Zone}

Authors: Čepek and Hay (1969), emended PerchNielsen (1977). 
Table 7. Biostratigraphic range chart, Hole 530A, late Turonian to late Albian. (See note, Table 1.)



Definition: Interval from the first occurrence of $\mathrm{Ce}$ ratolithoides aculeus (Stradner) to the first occurrence of Quadrum gothicum (Deflandre).

Age: Middle Campanian.

Assigned to Section 530A-66, CC.

Remarks to biostratigraphy: Despite the fact that only one core-catcher sample representing this nannofossil zone is available (no recovery for Core 65 and only $12 \mathrm{~cm}$ recovery ( $1 \%$ ) for Core 66 ), it can be convincingly demonstrated in Section 530A-66,CC. The base of the overlying Quadrum gothicum Zone is in 530A-64,CC, so there is a cored interval of $19 \mathrm{~m}$ unaccounted for between the nannofossil assemblages representing these two zones.

Only the lower boundary of this zone is certain; the upper boundary cannot be established because of failure of core recovery between $64, C C$ and $66, C C$.

Thierstein (1976) places the base of Tetralithus aculeus in the middle Campanian.

Verbeek (1976) claimed that the lowest forms of $C$. aculeus are rather complicated. These six-horned conical forms later were named $C$. verbeekii by Perch-Nielsen (1979). At Site 530 in the Angola Basin, rare specimens of $C$. verbeekii were found in the Broinsonia par- 
Table 7. (Continued).



ca Zone between Samples 530A-67-2, 77-78 cm and 530A-70-1, 33-34 cm. Verbeek also claims that the central structures of $B$. parca are usually rather narrow in this zone. Age assignment: Early Campanian to early part of Middle Campanian.

Manivit (1971) has selected the first occurrence of Lithraphidites quadratus for the upper boundary of this zone, but this datum is used nowadays higher up in the column.

Sissingh (1977) uses the first occurrence of T. nitidus Martini (?equivalent to $Q$. gothicum) as upper boundary level. Age: Latest part of the early Campanian.

Perch-Nielsen (1977) has observed this zone at Site 355 in the Brazil Basin and at Site 357 on the Rio Grande Rise.
Hattner and Wise (1980) used the Cepek and Hay (1969) definition emended by Perch-Nielsen (1977) except that they substitute the generic names Tetralithus and/or Quadrum with the new name Uniplanarius. Age: Late early to early middle Campanian.

At Site 530 Eiffellithus eximius does not, as they claim, have its last occurrence at the top of this zone, but higher up in the $Q$. trifidum zone (possibly because of reworking).

Cepek (1981) did not find this zone in the Pacific sites of Leg 62 and considers the possibility of a hiatus.

Pflaumann and Cepek (1982) have middle Campanian for the age of the $C$. aculeus Zone.

Remarks to chronostratigraphy: Thierstein (1976, fig. 8 , p. 349 ) has both the T. aculeus and T. trifidus bioho- 


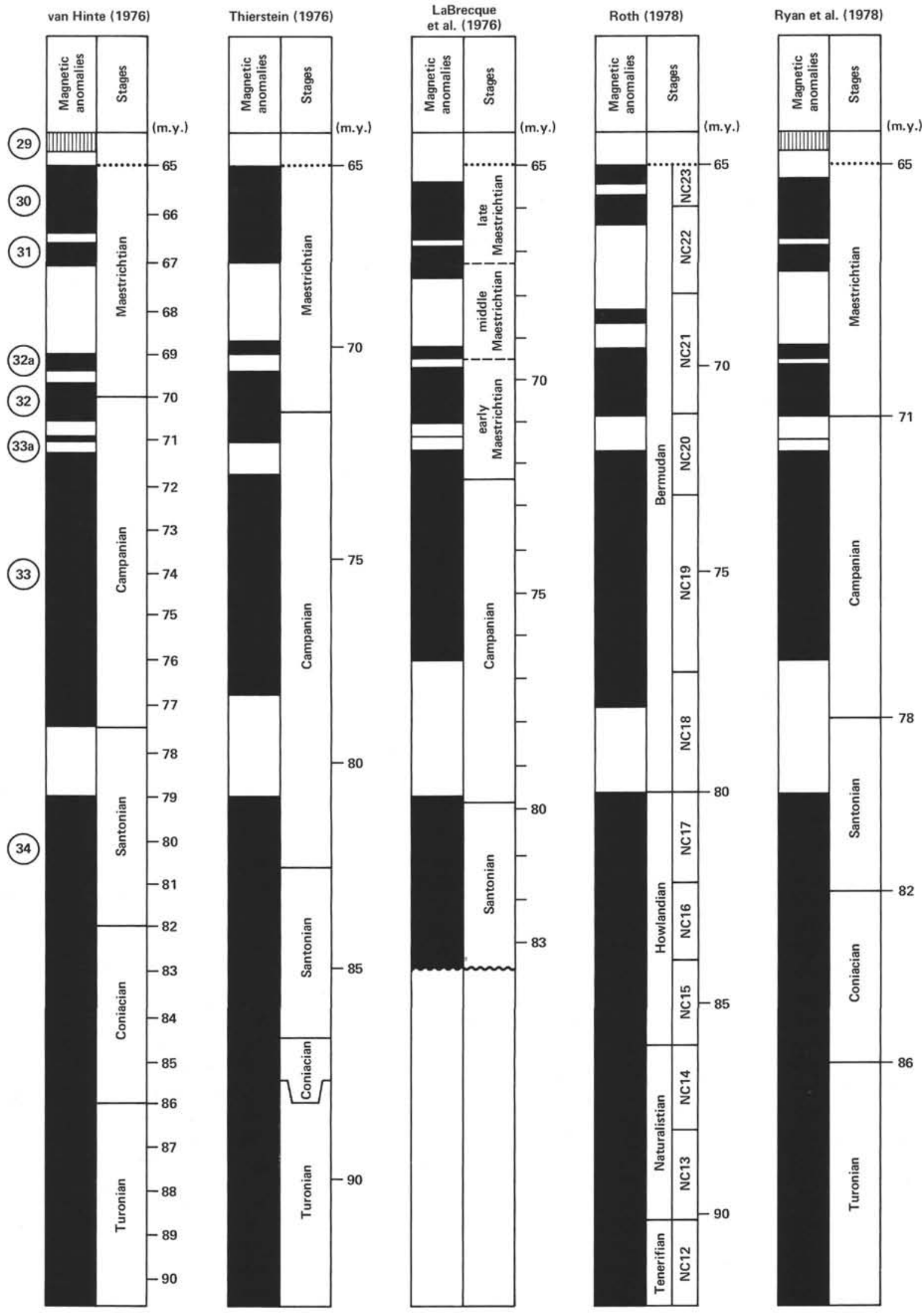

Figure 2. Correlation chart in which the Cretaceous biostratigraphy for Hole 530A is compared with the paleomagnetic time scales by van Hinte (1976), Thierstein (1976), LaBrecque et al. (1976), Roth (1978), Ryan et al. (1978), Perch-Nielsen (1979), Ness et al. (1980), Lowrie and Alvarez (1982), and Keating and Herrero-Bervera (this volume). 

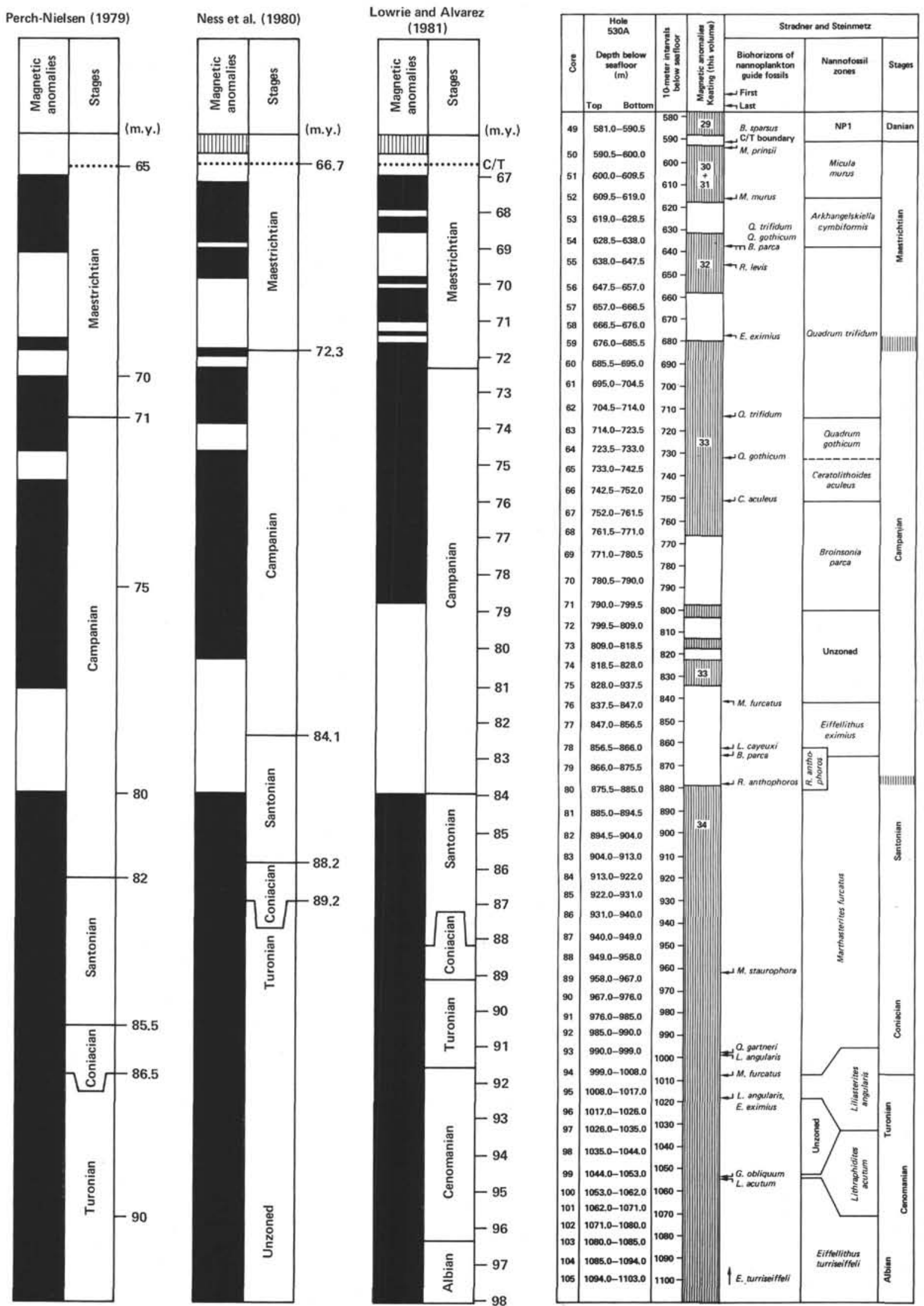

Figure 2. (Continued). 

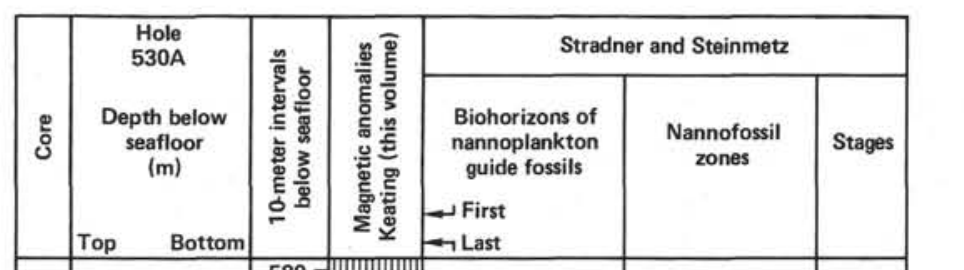

495

50 590.5-600.0

51 600.0-609.5

52 609.5-619.0

$53 \quad 619.0-628.5$

54 628.5-638.0

$55 \quad 638.0-647.5$

56 647.5-657.0

$57 \quad 657.0-666.5$

58 666.5-676.0

59 676.0-685.5

60 685.5-695.0

$61 \quad 695.0-704.5$

62 704.5-714.0

$63 \quad 714.0-723.5$

$64 \quad 723.5-733.0$

$65 \quad 733.0-742.5$

66 742.5-752.0

$67 \quad 752.0-761.5$

$68 \quad 761.5-771.0$

$69 \quad 771.0-780.5$

$70 \quad 780.5-790.0$

$71 \quad 790.0-799.5$

72 799.5-809.0

\begin{tabular}{l|l}
73 & $809.0-818.5$
\end{tabular}

Unzoned

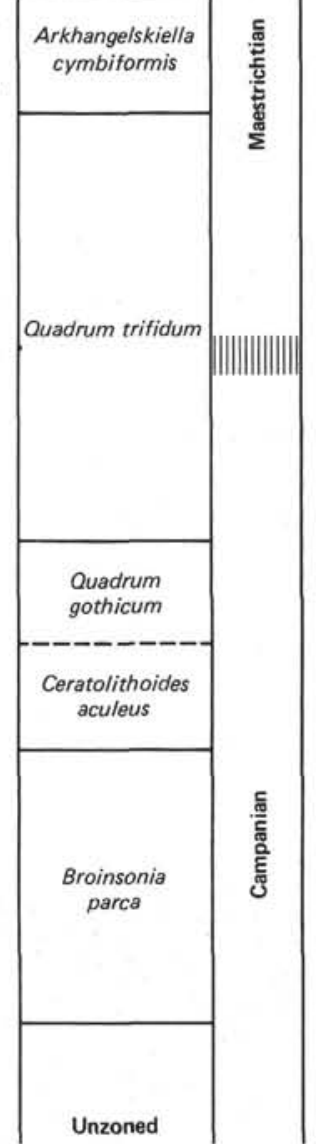

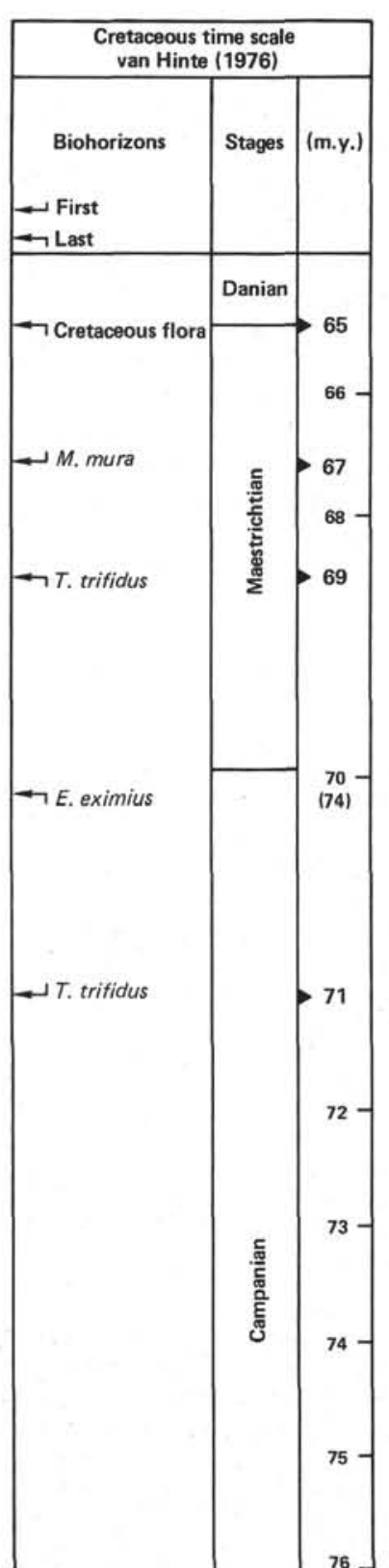

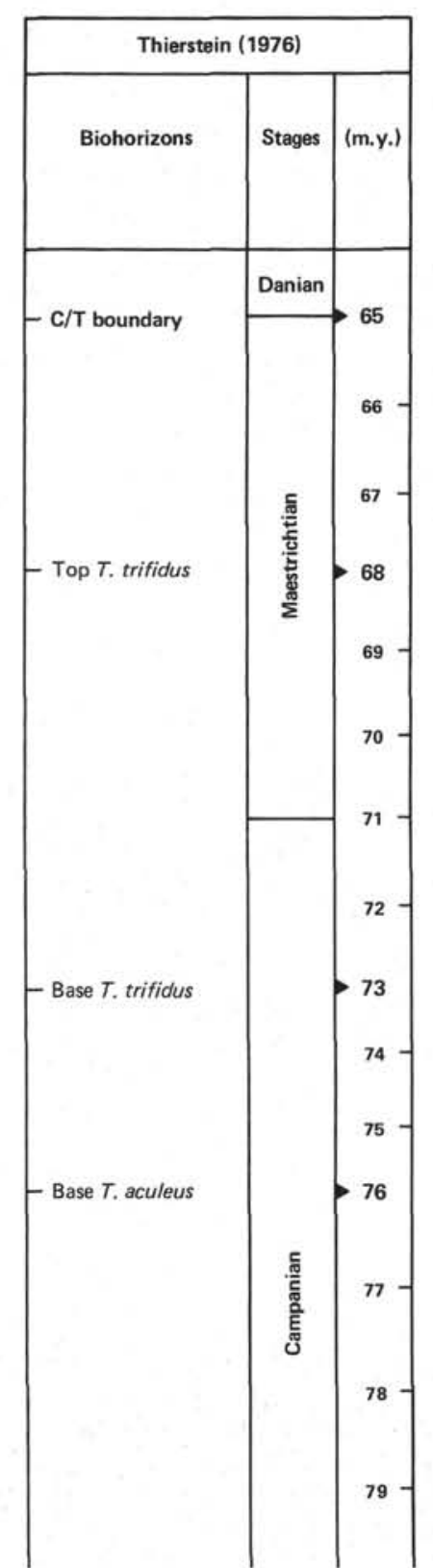

\begin{tabular}{|c|c|c|c|c|}
\hline \multicolumn{5}{|c|}{ Roth (1978) } \\
\hline $\begin{array}{l}\text { Biohorizons } \\
\text { First } \\
\text { Last }\end{array}$ & 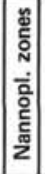 & 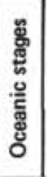 & 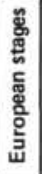 & (m.y.) \\
\hline 1 & & 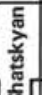 & 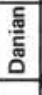 & 65 \\
\hline
\end{tabular}

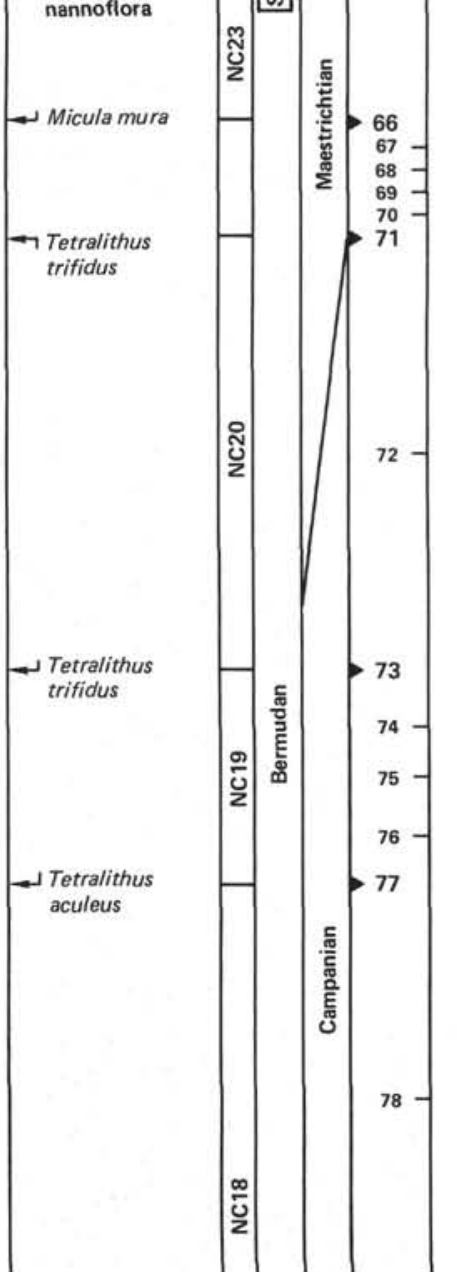




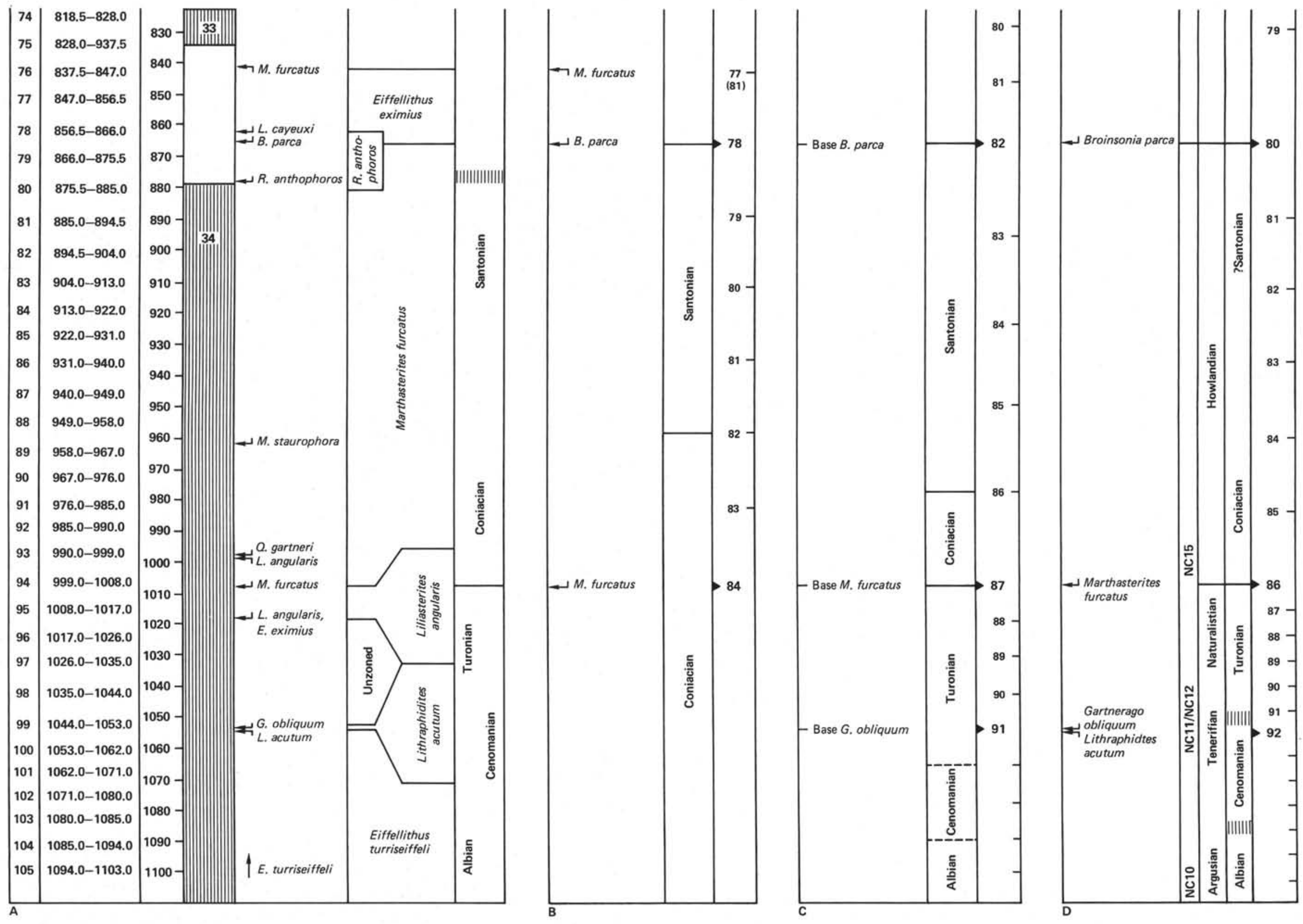



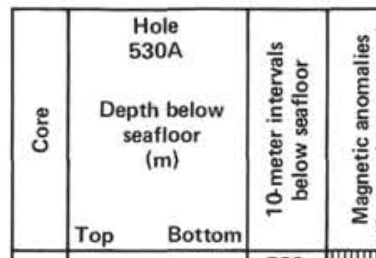



\begin{tabular}{l} 
Stra \\
$\begin{array}{c}\text { Biohorizons of } \\
\text { nannoplankton } \\
\text { guide fossils }\end{array}$ \\
\hline
\end{tabular}

Stradner and Steinmetz

nannoplankton
guide fossils $\rightarrow$ Last

$49 \quad 581.0-590.5$

50 590.5-600.0

$51 \quad 600.0-609.5$

$52 \quad 609.5-619.0$

$53 \quad 619.0-628.5$

54 628.5-638.0

$55 \quad 638.0-647.5$

$56 \quad 647.5-657.0$

$57 \quad 657.0-666.5$

58 666.5-676.0

59 676.0-685.5

60 685.5-695.0

$61 \quad 695.0-704.5$

62 704.5-714.0

$63 \quad 714.0-723.5$

$64 \quad 723.5-733.0$

$65 \quad 733.0-742.5$

66 742.5-752.0

$67 \quad 752.0-761.5$

68 761.5-771.0

69 771.0-780.5

70 780.5-790.0

71 790.0-799.5

72 799.5-809.0

\begin{tabular}{l|l}
73 & $809.0-818.5$
\end{tabular}

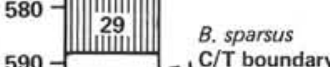

$590-{ }_{M} \mathrm{C} / \mathrm{T}$ boundary

$610-|| \begin{gathered}+ \\ 31\end{gathered}$

$620-1$ mund $\rightarrow M$ murus

$630-1$ O. trifidum

Q. gothicum

$650-||(32)|| \rightarrow$ R. levis

660

670

$680-$ E. eximius

690

$700-$

$710-$

720

$730-||||||||||||$ gothicum

740

$750-||(|-| \mid-5$. aculeus

$760-$

$770-$

$780-$

$790-$

$800-1$ mा mा mा

$810-$

820 -



\begin{tabular}{|c|c|}
\hline NP1 & Danian \\
\hline & \\
\hline
\end{tabular}



Quadrum trifidum |||||||||||||||

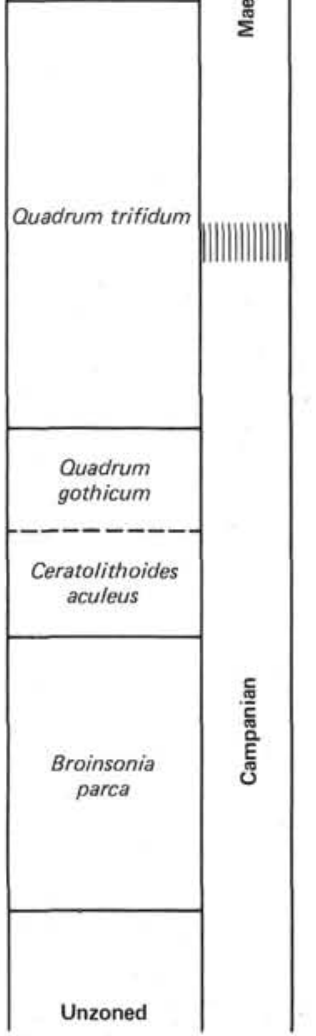

\begin{tabular}{|l}
\hline \\
\hline
\end{tabular}

Ryan et al. (1978) Proto Decima et al. (1978)

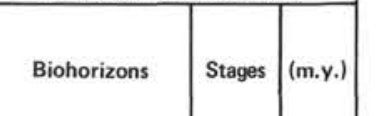

(1)

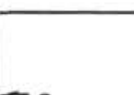

7 Cretaceous

extinction

M. mura

T. trifidus

$\neg T$. trifidus

(2)

$-\mathrm{T}$, trifidus

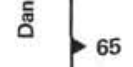

$\int_{66}^{65}$

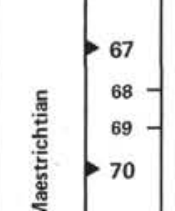

这



71

$72-$

73
Perch-Nielsen (1979)

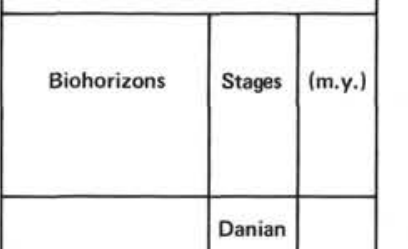

M. prinsii

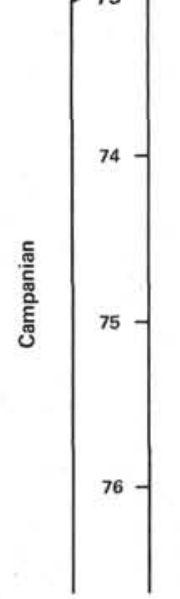

M. murus

A. parcus

$\rightarrow 0$. trifid

$\rightarrow$ E. eximius

Q. trifidum

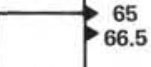

돈

总 66.5

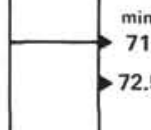

$-\rightarrow$ C. aculeus



Pflaumann and Čepek (1982)



M. mura

$\sqrt{\frac{9}{2}}{ }_{67}^{66}$

$\rightarrow T$. trifidus

T. trifidus

$-T$. gothicus

T. aculeus
Micula
mura
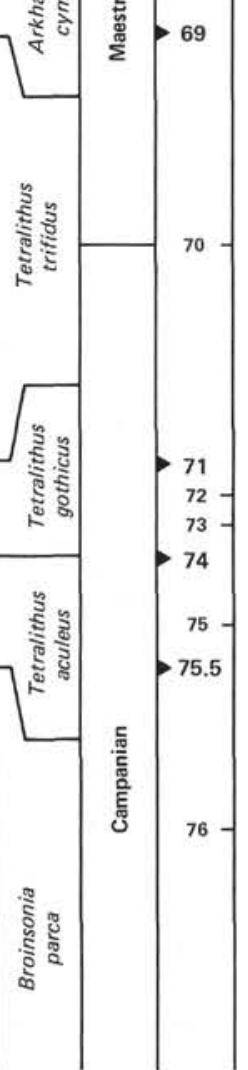

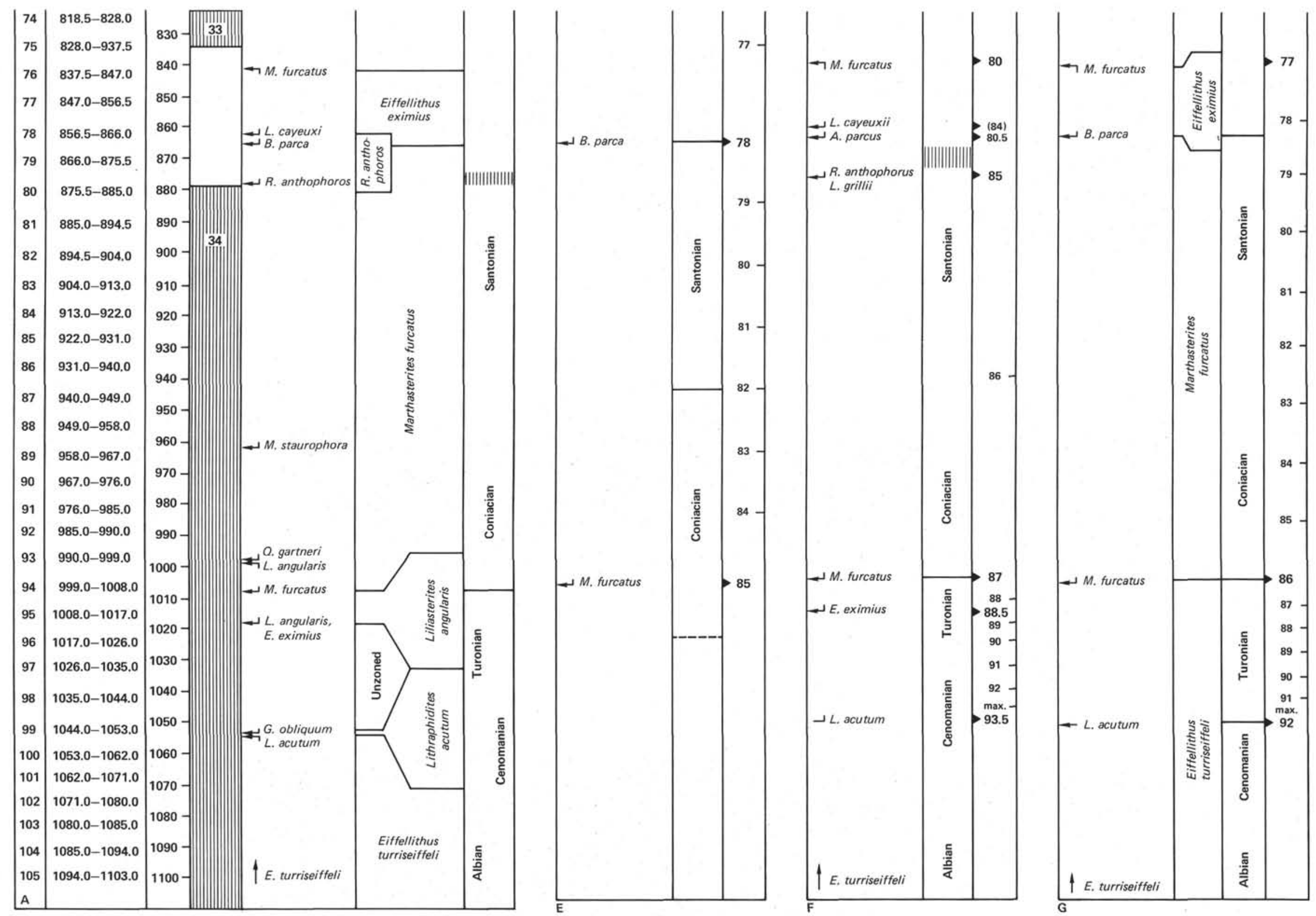

Figure 4. Correlation chart for Hole 530A in which the Cretaceous nannofossil biohorizons are correlated to the paleomagnetic anomalies as described by Keating and Herrero-Bervera (column A). are compared with the data of Hole $530 \mathrm{~A}$. 


\begin{tabular}{|c|c|c|c|c|}
\hline & & Age & $\begin{array}{c}\text { Calcareous nannoplankton } \\
\text { zone }\end{array}$ & Datum indicators \\
\hline \multirow{11}{*}{ 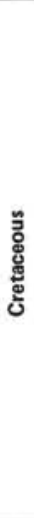 } & \multirow{10}{*}{$\stackrel{\Xi}{\Xi}$} & \multirow{3}{*}{ Maestrichtian } & Micula murus & \\
\hline & & & Arkhangelskiella cymbiformis & First Micula murus \\
\hline & & & Quadrum trifidum & Last Quadrum trifidum \\
\hline & & \multirow{4}{*}{ Campanian } & Quadrum gothicum & First Quadrum trifidum \\
\hline & & & Ceratolithoides aculeus & \multirow{2}{*}{ First Ceratolithoides aculeus } \\
\hline & & & Broinsonia parca & \\
\hline & & & Eiffellithus eximius & Last Marthasterites furcatus \\
\hline & & Coniacian and Santonian & Marthasterites furcatus & \multirow{2}{*}{$\begin{array}{l}\text { First Marthasterites furcatus } \\
\text { First Liliasterites angularis }\end{array}$} \\
\hline & & Turonian & Liliasterites angularis & \\
\hline & & Cenomanian & Lithraphidites acutum & First Lithraphidites acutum \\
\hline & 文 & Albian & Eiffellithus turriseiffeli & First Eiffellithus turriseiffeli \\
\hline
\end{tabular}

Figure 5. Nannofossil zonation for the Cretaceous, Hole 530A. (See also Figs. 2-4.)

Table 8. Biostratigraphic range chart, Hole 530A, late Albian. (See note, Table 1.)

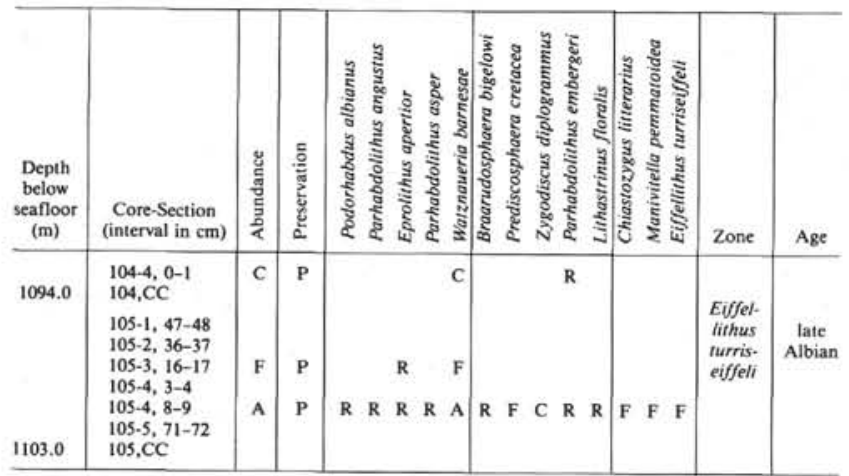

Note: The following species were not found: Ceratolithoides aculeus, Lithraphidites acutum, Liliasterites angularis, Liliasterites atlanticus, Zygodiscus anthophorus, Broinsonia bevieri, Watznaueria b porta, Lucianorhabdus cayewxi, Markalius circumradiatus, Micula concava, Cretarhabdus conicus, conatus, Cribrosphaerella ehrenbergi, Broinsonia enormis, Eiffelithus eximius, Microrhabdulus de lis, Marthasterites furcatus, Cylindralithus gallicus, discosphaerg grandis, Lithostrinus grilli, Bukryaster, Quadrum gartneri, Quadrum gothicum, Pred hus infinitus, Markalius inversus. Ceratholithoides kampi, Mrandis

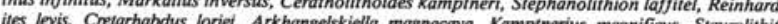

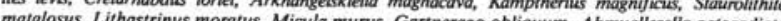

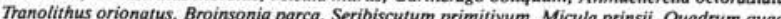
ratum, Lithraphidites quadratus, Gartnerago segmentatum, Lithastrinus spetengrius, Cylindrac thus serratus, Corollithion signum, Prediscasphaera spinosa, Zygodiscus spiralis, Purhabdolithus splendens, Micula stourophora, Microrhabdulus stradneri, Vekshinella stradneri, Gartnabdolithus tum, Zygodiscus theta, Helicolithus trabeculatus, Quadrum trifidum, Ceratolithoides verbeekii.

rizons in the Normal Polarity Anomaly 33, correlating them with the time interval from 73 to about 76 m.y.

Roth (1978, fig. 3, p. 736) also has these two biohorizons within the Normal Magnetic Anomaly 33, using them as lower and upper boundary for his NC19 in the lower part of the Bermudan Oceanic stage. Age of NC19: 73-77 m.y. for both C. aculeus and Q. gothicum zones combined.

Following Keating and Herrero-Bervera (this volume), the cores assigned to this zone lie within the lower half of the Normal Magnetic Anomaly 33. Perch-Nielsen (1977, fig. 11, p. 1116) correlates the lower part of Anomaly 33 with an age of about 73-75 m.y.

In Perch-Nielsen, 1979 (fig. 2) the Sissingh Zone 20, from the first occurrence of C. aculeus to the first oc- currence of $Q$. nitidum(?equivalent to $Q$. gothicum), is correlated with the time span of about 77 to 76 m.y.

\section{Quadrum gothicum Zone}

Author: Martini (1976).

Definition: Interval from the first occurrence of Quadrum gothicum (Deflandre) to the first occurrence of $Q$. trifidum (Stradner).

Age: Middle Campanian.

Assigned to the interval from $530 \mathrm{~A}-63-1,122-123 \mathrm{~cm}$ to $530 \mathrm{~A}-64, \mathrm{CC}$.

Remarks to biostratigraphy: Martini (1976), who described this zone in the Pacific, gave middle Campanian as the age. According to Verbeek (1977), who introduced the new generic name Quadrum for Tetralithus into the zonal definition, this zone has a restricted range. At Site 530 there are only $19 \mathrm{~m}$ of sediment of this zone, compared to $76 \mathrm{~m}$ of $Q$. trifidum Zone, in which $Q$. trifidum and $Q$. gothicum are co-occurring.

Perch-Nielsen (1977) found this zone at Sites 355, 356, and 357 in the South Atlantic. Assigned age is middle Campanian.

Sissingh (1977) uses the term Tetralithus nitidus partial-range zone for what seems to us the same intervalthat is, from the first occurrence of T. nitidus Martini to the first occurrence of T. trifidus Stradner emend. Age is late Campanian (early part).

Hattner and Wise (1980) substitute the new generic name Uniplanarius for Quadrum and/or T. gothicus; zonal boundaries are same as above.

Cepek (1981) has described this zone from the midPacific Sites 363, 365, and 366 and has given it a late Campanian age.

Remarks to chronostratigraphy: See Quadrum trifidum Zone.

\section{Quadrum trifidum Zone}

Authors: Bukry and Bramlette (1970).

Definition: Interval of the total range of Quadrum trifidum (Stradner). 
Age: Late Campanian to early Maestrichtian.

Assigned to interval from $530 \mathrm{~A}-55-1,17-18 \mathrm{~cm}$ to 530A-62, CC.

Remarks to biostratigraphy: This zone is considered a total range zone by most authors (Bukry and Bramlette, 1970; Bukry, 1973; Roth, 1973; Thierstein, 1973 and 1976; Martini, 1976; Perch-Nielsen, 1977; Proto Decima et al., 1978; Hattner \& Wise, 1980; Cepek, 1981; and Pflaumann and Cepek, 1982).

Thierstein (1976) remarked that this zone is valuable mainly in tropical areas, where Lithraphidites quadratus is absent or extremely rare. Perch-Nielsen (1977) indicated that this zone is easily recognizable in low latitudes.

Martini (1976) reported that the extinction of Broinsonia parca can be used instead of the slightly higher extinction of $Q$. trifidum in such sequences where $Q$. trifidum is absent.

Verbeek (1977) and Sissingh (1977) used different definitions for this zone. Verbeek's $Q$. trifidum Zone ends with the entry of $L$. quadratus Bramlette and Martini. Roth (1973), Hekel (1973), and Martini (1976) have reported a gap between the exit level of $Q$. trifidum and the appearance level of $L$. quadratus. For the hiatus between these two levels Martini (1976) used the Arkhangelskiella cymbiformis Zone of Perch-Nielsen (1972).

Sissingh (1977) used the last occurrence of Reinhardtites anthophorus (Deflandre) Perch-Nielsen as upper boundary of his Tetralithus trifidus concurrent-range zone and gave late Campanian (late part) for the approximate age.

At Site 530 both zonal concepts, the one with the total range of Quadrum trifidum as well as the other one using different top markers, are applicable. The tops of the ranges of $Q$. trifidum, $Q$. gothicum, and B. parca coincide with the top of Core 530A-55. So the upper limit of the early Maestrichtian can be drawn there. The tops of the ranges of Reinhardtites anthophorus and $E$. eximius coincide in Sample 530A-59-2, 104-105 cm, which can be taken as the upper Campanian boundary. According to Thierstein (1976) Eiffellithus eximius has its last occurrence at the Campanian/Maestrichtian boundary; according to Sissingh (1977) $R$. anthophorus expires at the same boundary. Also, Verbeek (1977) states that $E$. eximius disappears in the $Q$. trifidum Zone.

The first occurrence of $R$. levis, which according to Sissingh (1977) and Crux (1982) lies in the upper Campanian, fits into this zonal concept by overlapping the last occurrences of $R$. anthophorus and $E$. eximius.

In fig. 2 (calcareous nannofossil events) in PerchNielsen (1979) both $R$. anthophorus and $E$. eximius expire in the upper Campanian.

Remarks to chronostratigraphy: The $Q$. trifidum zone was assigned the following ages: Transitional between Maestrichtian and Campanian (Bukry and Bramlette, 1970); late Campanian to early Maestrichtian (Roth, 1973; Thierstein, 1973 and 1976; Perch-Nielsen, 1977; Hattner and Wise, 1980; Cepek, 1981; Pflaumann and Cepek, 1982).
In the Cretaceous Time Scale of van Hinte (1976) the Campanian/Maestrichtian boundary is given an age of 70 m.y.; in LaBrecque et al. (1977) it is given a slightly higher age of $72.5 \mathrm{~m}$.y. which in Ness et al. (1980) is corrected to $72.3 \mathrm{~m} . \mathrm{y}$.

Both the Quadrum gothicum and the $Q$. trifidum Zones are, for practical reasons, discussed here together, the former being of middle Campanian age, the latter straddling the Campanian/Maestrichtian boundary. Also, Lowrie and Alvarez use that age.

In Martini (1976 table 2, p. 386) the $T$. gothicus Zone has a range from 77 to 74 m.y., the $T$. trifidus Zone from 74 to 71 m.y., with the Campanian/Maestrichtian boundary at $72 \mathrm{~m} . \mathrm{y}$.

In Perch-Nielsen (1979, fig. 2, p. 227) the first occurrence of $Q$. nitidum (closely related to $Q$. gothicum) is at 76 m.y., at the base of Sissingh's Zone 21a, the total range of $Q$. trifidum between 74 and 70 m.y., embracing Sissingh's Zones 22a and 23b, with the Campanian/ Maestrichtian boundary at $71 \mathrm{~m} . \mathrm{y}$. The $Q$. gothicum Zone is less often found in use than the $Q$. trifidum Zone (evidently because it is much shorter).

Bukry (1974, p. 670, fig. 3) has the total range of $T$. trifidus from 75-69 m.y., with the Campanian/Maestrichtian boundary at 71 m.y. Thierstein $(1976$, p. 349 , fig. 8 ) has the $T$. trifidus Zone ranging from 73 to 69 m.y., the lower boundary lying within Magnetic Anomaly 33, and the upper boundary above the Campanian/Maestrichtian boundary for which $71 \mathrm{~m} . \mathrm{y}$. is taken.

Roth (1978, p. 736, fig. 3) identifies the total range of T. trifidus with his NC20 Zone in the middle of the Bermudan Oceanic Stage and assigns an age from 73 to $71 \mathrm{~m}$.y. The base of the T. trifidus Zone lies in the upper part of Magnetic Anomaly 33.

LaBrecque et al. (1977) correlate Magnetic Polarity Anomaly 33 with an age from 76.5 m.y. to 71.7 m.y. and Anomaly 32 from 71 m.y. to 69.2 m.y.

Perch-Nielsen (1979, p. 235, fig. 5) also shows Magnetic Polarities 33 and 32 in her column a, but has the Campanian/Maestrichtian boundary not within Anomaly 33, but in the middle of Anomaly 32. In Perch-Nielsen's fig. 5, Anomaly 32 ranges from 72 to 70 m.y., with the Campanian/Maestrichtian boundary at about 71 m.y., while in LaBrecque the boundary lies at $72.5 \mathrm{~m}$.y.

Ryan et al. (1978, p. 16, Table 6) have the T. trifidus Zone beginning above the middle of Magnetic Anomaly 33 and ending in the lower half of Anomaly 32. The age of $T$. trifidus Zone is 73.5 to 70 m.y., with the Campanian/Maestrichtian boundary at $71 \mathrm{~m}$.y.

Ness et al. (1980, fig. 2) use an age of 72.3 m.y. for the Campanian/Maestrichtian boundary, which was approved by Lowrie and Alvarez (1981, p. 396, fig. 6); however, their boundary does not lie in Anomaly 32a, but in the upper part of Anomaly 33 (see our Fig. 2).

Keating and Herrero-Bervera (this volume) found at Site 530 a normal polarity from Cores 68,69 to Cores 59, 60 and another one from Cores 57, 58 to Cores 54, 55. The lower normal interval, covering the $Q$. gothicum nannofossil zone, is recognized as Anomaly 33; the 
one which for the most part is covered by the range of Quadrum trifidum is recognized as Anomaly 32. The top of Magnetic Anomaly 33, which is interpreted by Keating and Herrero-Bervara as the Campanian/Maestrichtian boundary, lies between Cores 59 and 60 , slightly below the extinction levels of $E$. eximius and $R$. anthophorus; this provides a good correspondence between paleomagnetic and biostratigraphic data.

\section{Arkhangelskiella cymbiformis Zone}

Author: Perch-Nielsen (1972), emended Martini (1976).

Definition: Interval from the last occurrence of Quadrum trifidum (= Tetralithus trifidus) (Stradner) to the first occurrence of Lithraphidites quadratus Bramlette and Martini. tian.

Age: Early Maestrichtian to early middle Maestrich-

Assigned to interval from $530 \mathrm{~A}-54, \mathrm{CC}$ to $52, \mathrm{CC}$.

Remarks to biostratigraphy: This zone could be proven only for $19 \mathrm{~m}$ of sediment, between 619 and $638 \mathrm{~m}$ below seafloor. We are using here the same zonal definitions that Martini (1976), Perch-Nielsen (1977), Proto Decima et al. (1978), Hattner and Wise (1980), Cepek (1981), and Pflaumann and Cepek (1982) have been using.

Sissingh (1977) uses the last occurrence of Reinhardtites levis Prins and Sissingh for the base, which at Site 530 has its latest occurrence at $55-4,77-78 \mathrm{~cm}$. Because of the poor preservation of nannofossils in the Maestrichtian, more delicate species, such as $R$. levis, $L$. quadratus, and Nephrolithus frequens are rare or absent. L. quadratus was only found reworked above the Cretaceous/Tertiary boundary in Core 50-1, not where it should have been expected. The ecological environment in which $L$. quadratus had thrived is proven, but no autochthonous fossil record was left behind, except for those reworked specimens of Core 50-1. Therefore only the base level of the Arkhangelskiella cymbiformis Zone can be determined at Site 530 in the Angola Basin. The lack of a Lithraphidites Zone would suggest that part of the upper Maestrichtian is missing. Also, paleomagnetics would support the assumption of a hiatus somewhere between $530 \mathrm{~A}-51, \mathrm{CC}$ and the top of 530A55. The first occurrences of Micula murus and $M$. praemurus at 530A-51,CC mark an upper boundary for those sediments, which are assigned to the $A$. cymbiformis Zone.

Remarks to chronostratigraphy: The age of the extinction level of $Q$. trifidum, which at Site 530 is also the apparent extinction level of Q. gothicum and Broinsonia parca, was discussed in the remarks to the previous zone.

The age assignment for this zone in Martini (1976) is based on the interpretation of the Maestrichtian type locality. Cepek and Moorkens (1979) have shown that only the Gulpen Chalk $\mathrm{C}$ belongs in the $A$. cymbiformis Zone, while Gulpen Chalk E contains L . quadratus Zone and thus is one zone younger.

Van Hinte (1976) and Thierstein (1976) did not use this zone. In Ryan et al. (1978, p. 16, table 6), the lower part of the A. cymbiformis Zone can be correlated with the upper part of Magnetic Anomaly 32, the zone ranging from 70.5 to $68 \mathrm{~m} . \mathrm{y}$.

Roth (1978, p. 736, fig. 3) correlated this zone, which corresponds to his NC21 Zone in the Bermudan Oceanic Stage, to Magnetic Anomalies 32 and 31 and assigns an age of 71 to $67.5 \mathrm{~m} . \mathrm{y}$.

Perch-Nielsen (1979, p. 235, fig. 5) correlated the lower boundary of this zone, the extinction of $Q$. trifidum, with the top of Magnetic Anomaly 32 and an age of $70 \mathrm{~m} . \mathrm{y}$., and the top biohorizon with $L$. quadratus, to Magnetic Anomaly 30 and an age of slightly older than 66 m.y.

Keating and Herrero-Bervera (this volume) found Anomaly 32 from Cores 57, 58 to 54, 55. Thus at Site 530 the lower part of the A. cymbiformis Zone correlated with the upper part of Anomaly 32, just the same as in profiles of Leg 40 from the eastern South Atlantic (Ryan et al., 1978). Below the Cretaceous terminal event, which fell into the reversed interval between Magnetic Anomalies 30 and 29, Keating and Herrero-Bervera could demonstrate only one magnetic anomaly above Anomaly 32 and below Anomaly 29. As a result of poor recovery, which for Cores 52,53 , and 54 was only $14 \%$, $26 \%$, and $14 \%$, respectively, the chances for skipping such a short reversed interval, such as that between 30 and 31 , are greater than for finding it. Therefore, the highest normal polarity magnetic anomaly of the Cretaceous of Site 530 is thought to be Anomaly [ $30+$ 31] combined. The position of the Cretaceous/Tertiary boundary below Anomaly 29, as well as the small width of the reversed interval below this, seems to support this view. Also the Synthetic Anomaly Scale in Ness et al. (1980, fig. 2, p. 759) ought to be compared here. The almost equal length of 32 and [ $30+31]$ anomalies would suggest that our interpretation is correct and that a possible hiatus in the upper Maestrichtian was only of short duration (?one nannoplankton zone, the $L$. quadratus Zone).

\section{Micula murus Zone}

Author: Martini (1969).

Definition: Interval of the total range of Micula murus (Martini).

Age: Late Maestrichtian.

Assigned to interval $530 \mathrm{~A}-50-2,28-29 \mathrm{~cm}$ to $530 \mathrm{~A}-$ $51, \mathrm{CC}$.

Remarks to biostratigraphy: This topmost nannofossil zone of the Cretaceous was defined as the "Intervall vom ersten Auftreten von Tetralithus murus Martini bis zum Erlöschen der Maastricht-Arten.' The base with the first occurrence of the marker fossil is at Site 530 found in Core 51,CC, with typical specimens of Micula murus Martini and $M$. praemurus Bukry.

Since Nephrolithus frequens, which is another late Maestrichtian marker fossil with earlier first occurrence than Micula murus was not found at Site 530, only the M. murus Zone could be applied. Verbeek (1977) correlated this zone with the Racemiguembelina Zone and the Abathomphalus mayaroensis Zone and stated that Thoracosphaera operculata becomes more frequent near the top of the zone. As also noted by Worsley (1974), 
the relative frequence of $M$. staurophora is rather high in the upper Maestrichtian, which is the result of deterioration of the more delicate forms and preservation of the corrosion-resistant Micula.

At Hole 530A the general state of preservation near or at the Cretaceous/Tertiary boundary becomes better in some samples, so that the marked decrease in calcite contents at the boundary is also reflected in a lessening of recrystallization of nannofossils and better preservation. Thierstein (1981) remarked that the Late Cretaceous abundance fluctuations of nannofossils are most likely caused by differential diagenesis, which is also the case at Site 530. Perch-Nielsen (1977), who has found this zone at Sites 356 and 357 in the South Atlantic, considers the absence of $N$. frequens below or with $M$. murus to be a consequence of ecological condition and not an indication of a hiatus below the $M$. murus Zone.

Remarks to chronostratigraphy: At Hole $530 \mathrm{~A}$ the $M$. murus Zone starts near the base of the combined [ 30 + 31] magnetic anomalies and ends at the Cretaceous/ Tertiary boundary, which lies in the reversed anomaly between the Normal Events 29 and 30. Previous age assignments to this zone are: van Hinte (1976): 67 to 65 m.y.; Roth (1978): 66 to 65 m.y.; Ryan et al. (1978): 67 to 65 m.y.; Perch-Nielsen (1979): 66.5 to 65 m.y.; Pflaumann and Cepek (1982): 67 to 65 m.y.

These age assignments for the duration of the $M$. murus Zone are in general agreement with the magnetostratigraphic columns in van Hinte (1976)-his Anomalies 31 and 30 coinciding with the range of the $M$. murus Zone. In Ness et al. (1980) and Lowrie and Alvarez (1981), the C/T boundary is considered to be $66.7 \mathrm{~m} . \mathrm{y}$; thus the geologic ages are shifted down. In Ness et al. (1980) the Anomalies 30 and 31 taken together are from 70 m.y. to 66.8 m.y., and the short reversed anomaly at about 69 m.y. In Lowrie and Alvarez (1981, table 2, p. 394) the combined Anomalies 30 and 31 last from 68.62 to 66.98 m.y. Depending on which time scale is used, the approximate duration of the $M$. murus Zone of about 2 m.y. falls between 65 and 67 m.y. (van Hinte) or 66.7 and 68.6 m.y. (Lowrie and Alvarez).

\section{THE CRETACEOUS/TERTIARY BOUNDARY}

In Hole 530A the Maestrichtian/Danian boundary was found in Core 50. The lowermost reliable occurrence of Biantholithus sparsus was registered in Sample 530A-50-2, 29-29 cm.

Verbeek (1976) reported that considerable reworking of Cretaceous nannofossils is generally observed in the earliest Tertiary sediments. This was also the case in Core 50, Sections 1 and 2.

Thierstein and Okada (1979) showed that mixing of sediment not only brings the older sediment up, but also brings the younger ones down across the original contact level. This is accomplished by the work of burrowing animals, which can even go down as deep as $1 \mathrm{~m}$. Thus a mixing zone of about $1 \mathrm{~m}$ is realistic to assume in soft sediments. In Core 530A-50 the traces of burrowing creatures can be clearly seen. Therefore, a precise contact level cannot be observed, nor can the exact layer of the Cretaceous/Tertiary boundary be shown. Thus, too, the question of transition or unconformity cannot be settled by means of nannofossils, despite the fact that none of the earliest Danian nannofossil zones seems to be missing. Within the $150 \mathrm{~cm}$ from the first $B$. sparsus in an otherwise strictly Maestrichtian nannoflora up to the first typical Danian assemblage with only minor Maestrichtian admixture, there is much alternation of some poorly, some better preserved samples, and a transitional replacement of Maestrichtian taxa by the newly evolving Tertiary ones.

Also in Hole 530A there is a jump in frequency of Thoracosphaera operculata and T. saxea spheres or rather, because of the poor preservation, of fragments of these two dinoflagellate species. In the intermediate mixing zone, where reworked Maestrichtian nannofossils still dominate by far, these fragments of Thoracosphaera are the best indicators of where to look for the boundary layers, because the zonal markers for NP1 can be very rare.

For the early Danian nannofossil occurrences and their pictorial documentation the reader is referred to the chapter by Steinmetz and Stradner (this volume). Unfortunately, delicate species, such as Biscutum romeinii and Cruciplacolithus primus, are only rarely preserved in such a way that they can be studied by the scanning electron microscope, at least in such sediments as are present in Hole 530A.

\section{NOTES TO MAGNETOSTRATIGRAPHY}

Site 530 in the Angola Basin is remarkable in that a very successful paleomagnetic investigation was accomplished from Oligocene down to final depth in addition to a rather complete coring program (see Keating and Herrero-Bervera, this volume).

Figures 2-4 show how we have correlated nannofossil biostratigraphy with paleomagnetic data for the cores from Hole 530A and the way in which we think our data are comparable with time scales prepared previously by other authors and specialists of Cretaceous chronology. Most of our observations are discussed in the section on biostratigraphy in the remarks to each nannofossil zone. Here we again summarize each paleomagnetic zone found by Keating and Herrero-Bervera (this volume).

During Leg 75 in 1980 we used van Hinte's Cretaceous Time Scale; the revised age determinations by Ness et al. (1980) and Lowrie and Alvarez (1981) were not yet at hand. Thus, two sets of ages are given for each anomaly: one is in agreement with shipboard data, the other with modern revised data.

Anomaly 34: The long Normal Polarity Quiet Zone from basement below Core 105 up to Core 80 covers the interval from late Albian to late Santonian, that is from the Eiffellithus turriseiffeli Zone up to the top of the Marthasterites furcatus Zone. Age assignments: $~ 102$ to 79 m.y. (van Hinte, 1979); $\sim 98$ to 84 m.y. (Lowrie and Alvarez, 1981).

In Figure 2, the six columns between those of van Hinte (1976) and Lowrie and Alvarez (1981) show the variation in the position of the stage boundaries among 
the different authors. Since these columns are more or less self-explanatory, only the ages given by van Hinte (1976) and Lowrie and Alvarez (1981) are listed.

Anomaly 33: In Hole 530A, this anomaly extends from Core 75 up to Core 59 and embraces the Broinsonia parca Zone, the Ceratolithoides aculeus Zone, the Quadrum gothicum Zone, and the lower half of the Quadrum trifidum Zone.

By means of nannofossil biostratigraphy it can be shown that the interval from Cores 68 to 75 , despite the atypical reversed polarity intervals, falls within the limits of Anomaly 33, as it is within the range of Broinsonia parca. The top of Anomaly 33 is considered by Keating (this volume) to be the Campanian/Maestrichtian boundary level.

Age assignments: 77.5 to 71 m.y. (including Anomaly 33a) van Hinte (1976); 78.8 to 71.6 m.y. (Lowrie and Alvarez, 1981).

In comparing the positions of the Campanian/Maestrichtian boundary in the columns of Figure 2, we see that we are far from agreement as to where to place this boundary in respect to paleomagnetic stratigraphy.

Anomaly 32 and 32a: At Hole 530A no distinction between Anomaly 32 and the overlying 32a was possible. This anomaly, which we just call 32 , lies between Cores 54 and 57 and covers the upper part of the Quadrum trifidum Zone and the lower quarter of the Arkhangelskiella cymbiformis Zone.

Age assignments: 70.5 to 69 m.y. (van Hinte 1976); 71.2 to 69.8 m.y. (Lowrie and Alvarez, 1981).

Anomalies 31 and 30: These two anomalies have to be discussed together because at Hole 530A no reversed interval could be shown to be in between. Considering the poor core recovery, especially for the five top cores of the Maestrichtian, there is a possibility that this short reversed magnetic event was missed. Another possibility is an unconformity or hiatus, as suggested by Keating and Herrero-Bervera (this volume). At Hole 530A the topmost part of the Arkhangelskiella cymbiformis Zone and the major part of the Micula murus Zone correspond to these two magnetic anomalies. The $M$. murus Zone ranges up to the Cretaceous/Tertiary boundary, which lies in the reversed anomaly between 30 and 29 .

Age assignments: 67 to 65 m.y. (van Hinte, 1976); 68.6 to 67 m.y. (Lowrie and Alvarez, 1981)

Van Hinte positioned the Cretaceous/Tertiary boundary at the top of Anomaly 30 with an age of $65 \mathrm{~m}$.y.; Lowrie and Alvarez have the $\mathrm{C} / \mathrm{T}$ boundary as it was found at Gubbio, Italy, in the reversed interval (Gubbio $\mathrm{G}$ minus) between Anomalies 30 and 29, with an age of 66.7 m.y.

\section{NOTES ON INDICATIONS FOR HIATUSES}

In the background and objectives to Site 530, Hay and Sibuet have discussed the geology of nearby DSDP sites. At Site 363 an important regional seismic stratigraphic horizon was found to correspond to a hiatus between late Coniacian and late Albian strata. This prominent discontinuity had been recognized by Goslin et al. (1974). They indicated its extent across the sedimentary basin on top of the Walvis Ridge and into both the An- gola and Cape basins on their interpreted profiles. Sites 362 and 363 are up on the Walvis Ridge at shallower water depths.

Hay and Sibuet also discussed Sites 364 and 365 located on the continental margin about $840 \mathrm{~km}$ to the north of Site 530. There a prominent deeper acoustic reflector was found to correspond to the base of lithologic Unit 5, which includes late Coniacian to late Turonian and late Albian marls, chalks, and limestones, with sapropels separated by a hiatus representing the Cenomanian and early Turonian. In this area three main sequences bounded by discontinuities can be distinguished: the lowest, Discontinuity 1 , is thought to be a paraconformity where the Cenomanian and much or all of the Turonian is missing. Discontinuity 2, the top of the early Oligocene Braarudosphaera chalk, and Discontinuity 3 of middle Miocene age are important Cenozoic seismic horizons. A Cenomanian-Turonian hiatus near the base of the black shale sequence at Site 364 can be recognized throughout the area.

In order to find indications for hiatuses at Site $\mathbf{5 3 0}$ we have compiled Figures 3 and 4, where we have entered the nannoplankton horizons along with a column for core depth and geologic age; the paleomagnetic data for Hole 530A are by Keating and Herrero-Bervera (this volume).

If we correlate these data with those from the Cretaceous time scales by van Hinte (1976), Thierstein (1976), Roth (1978), Ryan (1978), Perch-Nielsen (1979), and Pflaumann and Cepek (1982), we see that there is no equal spacing in the columns marking the million year intervals. There are episodes, when we can observe compaction or dilation of time units, which would indicate either (1) markedly lowered sedimentation rates or unconformities and hiatuses in case of the compaction, or (2) excessive sediment supply or duplication of sediment layers in the case of widened time intervals.

Especially in columns C, D, F, and G we see that there is a compaction of the time intervals from Core 100 to Core 96-that is, from late Cenomanian to late Turonian. Since the youngest age of Core 100, Section 2 is early Turonian, the nannofossil age of that core would not contradict the assumption that the entire Cenomanian could be missing.

Higher up in the early Campanian-that is, above magnetic Anomaly 34-we can see that there is a widening of time intervals in columns D, F, and G. This means that at that time at Hole 530A more than the average amount of sediment was deposited. The irregularity of the magnetic events within Anomaly 33 and the proof of reworked Albian nannoplankton admixed to Core 77 would support the view that there is either a small number of repetitions of sediment packages of contemporaneous origin or just an increased sedimentation rate with a large amount of reworked material.

Up in the Maestrichtian we notice again a narrowing of time units, especially in the late Maestrichtian (compare columns D, E, and G). The early Maestrichtian ranges of Quadrum gothicum, Q. trifidum and Broinsonia parca all come to an end at the Core 55/54 boundary, which would suggest a hiatus there. There is no 
proof for the Lithraphidites quadratus zone at Site 530; however, the poor core recovery between Cores 52 and 58 (about $25 \%$ ) must also be taken into account. If there were hiatuses in the Maestrichtian of Hole 530A they cannot have been of much import, because the relative lengths of Magnetic Anomalies 33, 32, and [31 + 30] compare well with the magnetic scale of Lowrie and Alvarez (1981).

\section{NOTES ON PALEOECOLOGY}

In the black shales, which at Hole 530A are found from Coniacian (Core 87) down to late Albian (Core 105), the state of preservation of coccoliths and other nannofossils is generally poor, degrading from bad to worse. Müller $(1979$, p. 608$)$ has noted that in the dark layers which have higher contents of organic material and pyrite, the dissolution is stronger than in the gray sediment where the nannofossils are only slightly etched. Different physicochemical conditions in the surface sediments seem to have been responsible for the deterioration of calcareous nannofossils.

Figures 1 and 2 of Plate 52 show how nannofossils in one of the better preserved samples between the black shale layers present themselves in the scanning electron microscope. The importance of nannofossils in sediment formation as contributors of "micritic" grains has been discussed in detail by Schneidermann (1973). He stresses that the presence of dissolved coccoliths does not have to indicate a diagenetic process, but may well be a primary depositional feature occurring during their descent and on the bottom of the ocean.

In the lower Campanian of Sample 77-7, 15-16 cm (see Plates 34, 50, and 51), a lower Cretaceous nannoflora was found as reworked admixture to the existing Campanian nannoflora. Since Hole 530A is at some distance from the continental margin, the transport of the displaced nannoflora seems to have been accomplished by a submarine fan system. The characteristic species of this allochthonous-heterochronous nannoflora are: Nannoconus globulus, $N$. truitti, N. bucheri, Parhabdolithus embergeri, Braarudosphaera africana, P. angustus, Watznaueria barnesae.

The presence of the short, inflated Nannoconus species and of Parhabdolithus angustus suggest a derivation from late Aptian strata. This reworked nannoflora constitutes the oldest nannoplankton evidence at Hole 530A. It differs from the autochthonous Albian, in which nannoconids are lacking, by its numerous Nannoconus and Braarudosphaera specimens, a strong indication for a near-shore environment.

The nannofossil assemblages of Hole 530A from late Albian up to Maestrichtian indicate open sea conditions rather than a near shore environment. In the Late Cretaceous, Lucianorhabdus cayeuxi, typical for marginal conditions, is rather rare, even in the better samples of Campanian age. Confirming the observations of Müller (1979, p. 611) that Quadrum trifidum of the uppermost Campanian-lowermost Maestrichtian is abundant in samples from deeper water farther away from the continent, with Lucianorhabdus cayeuxi essentially absent, we could find the same relations in the Quadrum trifidum Zone samples of Hole 530A.
The late Maestrichtian of Hole 530A mainly contains overcalcified nannofossils, with Micula staurophora in great abundance. This species is very resistant to diagenetic destruction and is thus one of the last survivors in poorly preserved samples. At the Cretaceous/Tertiary boundary nannofossil preservation becomes markedly better, which might be a result of the decrease of calcite supply to the sediment following the Cretaceous/Tertiary event.

Thierstein (1981) concluded that the Late Cretaceous abundance fluctuations at Site 356 in the South Atlantic are most likely caused by differential diagenesis. This also can be observed in Sections 1 and 2 of Core 530A-50.

In the North Atlantic, at Site 384 (Thierstein and Okada, 1979), the Cretaceous nannofossil assemblage of the latest Maestrichtian is replaced by the Danian assemblage within less than $1 \mathrm{~m}$ of sediment thickness. At Hole 530A this distance is about $150 \mathrm{~cm}$.

In a quantitative analysis of earliest Danian nannofossil assemblages in the Atlantic, Haq and Lohmann (1976) have shown two different characteristic communities: a neritic one dominated by Braarudosphaerids, and an oceanic one, dominated by Thoracosphaerids. At Hole 530A, with Braarudosphaera essentially absent and Thoracosphaera fragments common, the nannoplankton assemblage indicates oceanic conditions during the deposition of the sediments after the Cretaceous/Tertiary event, the same as with the Late Cretaceous sediments.

\section{NOTES ON NANNOFOSSIL PALEONTOLOGY}

The following text gives additional information on a few selected species of nannofossils, all of which were found in the Cretaceous of Hole 530A in the Angola Basin. Electron micrographs from specimens extracted from the original type material of these species are discussed.

\section{Broinsonia parca (Stradner 1963) Bukry 1969}

(Plate 2; Plate 3, Figs. 4-9; Plate 4)

Remarks: Because most of the biostratigraphic work on the cores of Hole 530A was done with the light microscope, the overall dimensions of Broinsonia parca (long axis more than $10 \mu \mathrm{m}$ ) were used to determine the first occurrence of this species within the early Campanian in Core $78, \mathrm{CC}$. The relations between the b/a ratios ${ }^{3}$ of late Campanian specimens versus older ones are still waiting for a detailed statistical study. B. enormis was described from a holotype, which measured only $6 \mu \mathrm{m}$ and is of late Turonian origin. Only such small specimens of Broinsonia with high b/a ratios were included in $\boldsymbol{B}$. enormis. As Crux (1982) has shown, the evolutionary trends of $B$. par$c a$, on which Lauer (1975), Verbeek (1977), Thierstein (1976), and Prins (1979) worked, still need more statistical work. One important question is whether the b/a ratios of one and the same sample are the same in normal light, in polarized light, and in the TEM or SEM electron microscope. In the type sample of $\boldsymbol{B}$. parca from the Perwang 1 deepwell in upper Austria (where it is found in the lower part of the Quadrum trifidum zone within the range of Eiffellithus eximius), the types show b/a ratios of approximately 1 in the light microscope, and less than 1 in the SEM micrographs (compare Plate 4). Specimens of Broinsonia parca from Hole 530A (see Plate 2) show b/a ratios varying from 1 to 1.25 in samples which are definitely early Campanian (E. eximius Zone).

\footnotetext{
${ }^{3}$ The b/a ratio is the diameter of the central area versus the width of the rim measured along the short axis of the ellipse
} 
Ceratolithoides aculeus (Stradner, 1961) Prins and Sissingh (1977)

(Plate 6, Figs. 1-3; Plate 7, Figs. 1-5; text-Figs. 6C, 6D.)

Remarks. In Hole 530A Ceratolithoides aculeus was found between Cores 51 and 66-that is, between late Campanian and late Maestrichtian; the rare $C$. verbeekii was found between Cores 66 and 69 in the early Campanian, which is in good agreement with the distribution chart of Ceratolithoides in Perch-Nielsen (1979, fig. 11).

The evolutionary trend from wider to smaller angles between the horns of $C$. aculeus could not be proven in the Hole 530A samples, because recrystallization of the Ceratolithoides specimens in the late Maestrichtian (compare Plate 7, Fig. 4) seems to affect the shape and opening angle of the horns.

C. verbeekii, which consists of six horns of about equal size, is undoubtedly a forerunner species of C. aculeus. In the electron micrographs of the latter species from Sample 530A-57-2, 65-66 cm and also from lectotypes from the original type sample, one can distinguish between two large horns and four reduced horns (two on each side), which are reduced to thin triangular plates (see Fig. 6C, 6D) Evidently, there was a transition from radial or axial symmetry in $C$. verbeekii to bilateral symmetry in $C$. aculeus. If we start numbering with a large horn, then numbers 1 and 4 are pronounced, while numbers 2 and 3 on one side and 5 and 6 on the reverse side are reduced to flat plates.

Gartnerago striatum (Stradner, 1963) Forchheimer (1972)

(Plate 18, Figs. 9 and 10, and Plate 19, Figs. 1-4.)

Remarks. This species, which at Hole 530A was found to occur between Sections 100-2 and 104-1 (Eiffellithus turriseiffeli Zone and Lithraphidites acutum Zone) has a range from late Albian to late Coniacian (Perch-Nielsen, 1979, fig. 6). At present, no electron micrographs of this species from Hole 530 samples are available; a set of electron micrographs from the original type sample from the Albian of the Delft 2 deepwell in the Netherlands is shown in Plate 19. These micrographs, which in our opinion show the species described as Arkhangelskiella striata Stradner (1963), compare well with electron micrographs of Crucicribrum anglicum (Black, 1972, pl. 22, figs. 11-15). In the event that future studies of the rim structure show basic differences between the rims of the Early Cretaceous genus Crucicribrum and the Late Cretaceous genus Gartnerago, then a transfer of this species from Gartnerago to Crucicribrum would be advised.

\section{Liliasterites nov. gen. Stradner and Steinmetz}

Remarks. This genus comprises six-rayed, star-shaped, flat, calcareous nannofossils, composed of angular elements. In better-preserved specimens, sutures can be observed. Two levels of rays-that is rays 1 , 3 , and 5 in the upper level and rays 2, 4, and 6 in the lower level, with the intervals between the rays alternatingly wide and narrow-give these forms a close similarity to Marthasterites contortus. They differ from Marthasterites by the presence of sutures. Also, disintegrated angular elements throw light on the composition of Liliasterites, which possibly is an ancestor of the genus Marthasterites.

Derivation of name: The six rays of this nannofossil alternate in two levels, reminiscent of the three petals and three sepals in the flower of a lily (latin Lilium).

Genero-type: Liliasterites angularis Švábenická \& Stradner

Liliasterites atlanticus nov. spec. Stradner and Steinmetz

(Plate 22, Fig. 7; Plate 23, Figs. 1, 2, 4-7, text-Fig. 6B)

Remarks. A species of Liliasterites with broad, truncated rays, the ends of which are either notched or block-shaped. Three alternating rays with angles of 120 degrees between them in one level are offset against the other three rays by about 60 degrees, so that three bundles of two alternating arms result.

Type specimens: Plate 23, Fig. 5 (holotype); Plate 22, Fig. 7, Plate 23, Figs. 2 and 4 (paratypes).

Type sample: Sample 530A-95-1, 107-108 cm.

Type level: Late Turonian

\section{Notes on Liliasterites angularis nov, spec.: Its type-locality and geologic age}

L. Švabénická and H. Stradner.

This species of calcareous nannofossil was discovered independently and simultaneously by the Geological Survey of CSSR, Prague, in
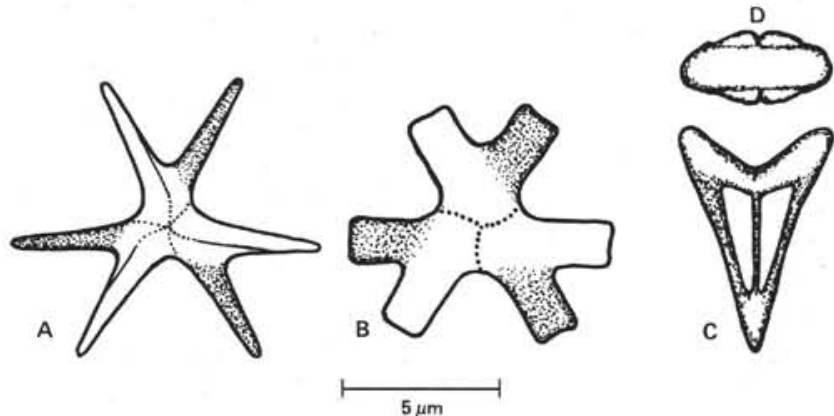

Figure 6. A. Plane view of Liliasterites angularis. B. Same view of $L$. atlanticus. (In A and B the dotted parts of the suture-lines are hypothetical.) C. Ceratolithus aculeus in lateral view. D. What this species is thought to look like in axial view.

samples from Bohemia, and by the Geological Survey of Austria, Vienna, in samples from DSDP Leg 75. Instead of competing for priority, we have decided to co-author and to combine our preliminary results in these notes.

\section{Liliasterites angularis nov. spec. Švábenická and Stradner (Plate 24, Figs. 1-4; text Fig. 6A)}

Remarks. A species of Liliasterites with six tapering, pointed rays. In the central area three-rayed symmetry dominates. Two neighboring rays, each in a different level, are separated by a suture line, which indicates that the nannofossil is composed of angular elements (hence the species epithet "angularis").

Type specimens: Plate 24, Fig. 1 (holotype); Figs. 2-4 (paratypes).

Type locality: Right bank of the Ohře river, S. of Kystra village, CSSR.

Type level: Late Turonian

Dimensions: Diameter of holotype: $12 \mu \mathrm{m}$. Length of free ray: $4 \mu \mathrm{m}$.

Ocurrence in the Angola Basin, South Atlantic: DSDP Sample 530A-95-1, 107-108 cm. Late Turonian.

Discussion: Liliasterites angularis together with $L$. atlanticus are considered evolutionary steps in a line which leads to the genus Marthasterites.

L. angularis marks with its first occurrence the lower boundary of the new late Turonian nannoplankton zone bearing its name.

In Bohemia, $L$. angularis is a rare species in a late Turonian nannoflora without Marthasterites furcatus and without Micula staurophora. The layer in which it is found is between 3 and $4 \mathrm{~m}$ below the so-called coprolite horizon, which marks the upper boundary of the Jizera Formation to the overlying Teplice Formation. A detailed description of these two formations is to be found in Cech et al. (1980, pp. 286-291). A diagrammatic section of the lower Teplice Formation and the upper Jizera Formation at Kystra is shown in fig. 9 of that paper. The Kystra samples with $L$. angularis are a deep-grey, calcareous claystone with silty admixture and biodetrital streaks. The village of Kystra lies near Louny in the western part of the Bohemian Cretaceous Basin. The exposure is $150 \mathrm{~m}$ long and $20 \mathrm{~m}$ high, on the right bank of the Ohre river south of Kystra.

In Krhovsky (1981, p. 21) Švábenická has reported on the occurrence of Marthasterites furcatus in the coprolite layer of Kystra (lowest occurrence) and at 0.55 and $2.5 \mathrm{~m}$ above the coprolite layer. This indicates that the coprolite layer at Kystra corresponds to the base of the $M$. furcatus nannoplankton zone, which is considered the base of the Coniacian (sensu Cepek and Hay, 1969, emend. Perch-Nielsen, 1977). In Bohemia, the correlation between Inocerami and $M$. furcatus at the Turonian/Coniacian boundary by Krhovsky (1981) has shown the importance of more detailed biostratigraphic work being done at the new standard Turonian and Coniacian stratotypes.

Krhovsky concludes that in the Cretaceous of Bohemia the Turonian/Coniacian boundary is to run along the IX-X Formations contact in the upper Jizera formation, provided that $M$. furcatus is proven at the Coniacian stratotype. The Inoceramus schloenbachi-I. inconstans group would thus be of Coniacian age. Possibly the distinction between the genera Liliasterites and Marthasterites in the critical boundary layers will provide means for a more detailed zonation. 
Micula swastica (sensu Prins, 1977) Stradner and Steinmetz nov, spec.

(Plate 31, Figs. 3, 5, and 6.)

Remarks. In November 1977, B. Prins demonstrated the evolutionary trends from Eprolithus Stover to Micula Vekshina at a meeting on mid-Cretaceous nannofossils in The Hague, Netherlands. In his lectures he applied the new name "Micula swastica" to those types of Micula which show crooked suture lines and which finally evolved into $M$. murus and $M$. prinsii. As far as we know, this new name has not yet appeared in print. At Hole 530A such types, which fit into the pictorial definitions of $M$. swastica and $M$. cf. swastica sensu Prins (1977) are described as follows:

Description: Cube-shaped calcareous bodies composed of two layers, each consisting of four hook-shaped elements combined in such a way that the suture-lines on two opposing faces of the cube form a "swastica."

Derivation of name: In ancient Indian a "swastica" was a kind of cross emblematic for the sun.

Holotype: Plate 31, Fig. 6; Paratype: Plate 31, Fig. 3.

Type-sample: DSDP Sample $530 \mathrm{~A}-50-2,13-14 \mathrm{~cm}$.

Type-level: Upper Maestrichtian, at the Cretaceous/Tertiary boundary.

Reference: Prins (1977): Meeting on mid-Cretaceous Nannofossil. Working papers, chapter on Micula, pl. 9, figs. 4, 6; pl. 10, figs. 1a1c. Crux 1982, p. 99.

\section{New Combinations of Nannofossil Names:}

Corollithion baldiae (Stradner and Adamiker, 1966) nov. comb. ex Zygolithus baldiae nov. spec. Stradner and Adamiker (1966, p. 338 , pl. 2, fig. 2; text-figs. 3 and 4).

Micula praemurus (Bukry, 1973) nov. comb. ex Tetralithus praemurus Bukry, 1973, p. 308; pl. 2, figs. 6-9.

\section{ACKNOWLEDGMENTS}

We are grateful to our co-chiefs W. W. Hay and J.-C. Sibuet and to our fellow shipboard scientists for their collaboration on board the D/V Glomar Challenger and during subsequent meetings, as well as to Dr. Katharina Perch-Nielsen and Dr. Pavel Cepek for critically reading the manuscript. We gratefully acknowledge that permission to participate in DSDP Leg 75 and subsequently to use the laboratory facilities of the ELMI-Lab of the Geological Survey of Austria was granted to the senior author by Deputy-Director HR. Prof. Dr. T. Gattinger, by Dr. W. Janoschek, and by the late Director HR. Prof. Dr. F. Ronner.

Special thanks too to the DSDP editorial staff for their efforts and to the SEM operator Franz Allram, who contributed to the electron microscopic documentation of Hole 530A coccoliths. Last, but not least, thanks to Associate Chief Scientist Russ Merrill and to Robert Boyce for their patience and steady encouragement.

\section{REFERENCES}

Alvarez, W., Arthur, M. A., Fischer, A. G., Lowrie, W., Napoleone, G., Premoli Silva, I., and Roggenthen, W. M., 1977. Upper Cretaceous-Paleocene magnetic stratigraphy at Gubbio, Italy-V. Type section for the Late Cretaceous-Paleocene geomagnetic reversal time scale. Geol. Soc. Am. Bull., 88:383-389.

Black, M., 1972. British Lower Cretaceous coccoliths. I. Gault clay. Palaeontograph. Soc. Monogr., 1-142.

Bukry, D., 1969. Upper Cretaceous coccoliths from Texas and Europe. Univ. Kansas Paleont. Contrib., 51.

1973. Phytoplankton stratigraphy, Deep Sea Drilling Project Leg 20, Western Pacific Ocean. In Heezen, B. C., MacGregor, I. D., et al., Init. Repts. DSDP, 20: Washington (U.S. Govt. Printing Office), 307-317.

1974. Cretaceous and Paleogene coccolith stratigraphy, Deep Sea Drilling Project, Leg 26. In Davies, T. A., Luyendyk, B. P., et al., Init. Repts. DSDP, 26: Washington (U.S. Govt. Printing Office), 669-673.

Bukry, D., and Bramlette, M. N., 1970. Coccolith age determinations Leg 3, Deep Sea Drilling Project. In Maxwell, A. E., Von Herzen, R. P., et al., Init. Repts. DSDP, 3: Washington (U.S. Govt. Printing Office), 589-611.
Čech, S., Klein, V., Křiž, J., and Valečka, J., 1980. Revision of the Upper Cretaceous stratigraphy of the Bohemian Cretaceous Basin. Vest. Ust. Ustr. Geol., 55(5):277-296.

Čepek, P., 1981. Mesozoic calcareous-nannoplankton stratigraphy of the central north Pacific (Mid-Pacific Mountains and Hess Rise), Deep Sea Drilling Project Leg 62. In Thiede, J., Vallier, T. L., et al., Init. Repts. DSDP, 62: Washington (U.S. Govt. Printing Office), 397-418.

Čepek, P., and Hay, W. W., 1969. Calcareous nannoplankton and biostratigraphic subdivision of the Upper Cretaceous. Gulf Coast Assoc. Geol. Soc. Trans., 19:323-336.

1970. Zonation of the Upper Cretaceous using calcareous nannoplankton. Proc. Paleobot., B3:333-340.

Crux, J. A., 1982. Upper Cretaceous (Cenomanian to Campanian) calcareous nannofossils. In Lord, A. R. (Ed.), A Stratigraphical Index of Calcareous Nannofossils. Brit. Micropalaeontol. Soc. Ser., pp. 81-135.

Forchheimer, S., 1972. Scanning electron microscope studies of Cretaceous coccoliths from Köpingsberg Borehole No. 1, S.E. Sweden. Sveriges Geol. Undersökning C 668, Arsbok, 65(14):1-141.

Gartner, S., 1968. Coccoliths and related calcareous nannofossils from Upper Cretaceous deposits of Texas and Arkansas. Univ. Kansas Paleont. Contrib., 48:1-56.

Goslin, J., Mascle, J., Sibuet, J.-C., and Hoskins, H., 1974. Geophysical study of the easternmost Walvis Ridge, South Atlantic: Deep structure. Geol. Soc. Am. Bull., 86:1713-1724.

Hattner, J. G., and Wise, S. W., 1980. Upper Cretaceous calcareous nannofossil biostratigraphy of South Carolina. S. C. Geol., 24(2): 41-117.

Hay, W. W., 1970. Calcareous nannofossils from cores recovered on Leg 4. In Bader, R. G., Gerard, R. D. et al., Init. Repts. DSDP, 4: Washington (U.S. Govt. Printing Office), 455-501.

Krejč́, J., 1867. Bericht der Sektion für Geologie für das Jahr 1865 und 1866. Zweiter Jahresber. Wirksamkeit über die beiden Comités für die Naturwiss. Durchforschung von Böhmen im Jahre 1985 und 1866. pp. 27-66.

1869. Studien im Gebiete der böhmischen Kreide-formation. Arch. Naturwiss. Landesdurchforsch. Böhmen, 1:41-179.

Krhovskyý, J., 1981. The stratigraphical position of the lower boundary of the Marthasterites furcatus nannoplankton Zone in the Bohemian Cretaceous Basin. Vestnik Ústrèdniho Geol., 56(1):21-26.

LaBrecque, J. L., Kent, D. V., and Cande, S. C., 1977. Revised magnetic polarity time scale for Late Cretaceous and Cenozoic time. Geology, 5:330-335.

Larson, R. L., and Hilde, T. W. C., 1975. A revised time scale of magnetic reversals for the Early Cretaceous and Late Jurassic. J. Geophys. Res., 80:2586-2594.

Larson, R. L., and Pitman, W. C. III, 1972. Worldwide correlation of Mesozoic magnetic anomalies, and its implications: Geol. Soc. Am. Bull., 83:3645-3662.

Lord, A. R., 1982 (Ed.). A Stratigraphical Index of Calcareous Nannofossils: Chichester (Ellis Horwood Ltd.), Brit. Micropalaeontol. Soc. Ser.

Lowrie, W., and Alvarez, W., 1981. One hundred million years of geomagnetic polarity history. Geology, 9:392-397.

Manivit, H., 1971. Les Nannofossiles calcaires du Crétacé français (Aptien-Maestrichtien). Essai de biozonation appuyée sur les stratotypes [These], Université de Paris, France.

Manivit, H., Perch-Nielsen, K., Prins, B., and Verbeek, J. W., 1977. Mid-Cretaceous calcareous nannofossil biostratigraphy. Proc. Kon. Ned. Akad. Wet., B80:169-181.

Martini, E., 1969. Nannoplankton aus dem Latdorf (locus typicus) und weltweite Parallelisierung im oberen Eozän und unteren Oligozän. Senckenb. Lethaea, 50(2/3):117-159.

1976. Cretaceous to Recent calcareous nannoplankton from the central Pacific Ocean (DSDP Leg 33). In Schlanger, S. O., Jackson, E. D., et al., Init. Repts. DSDP, 33: Washington (U.S. Govt. Printing Office), 383-423.

Müller, C., 1979. Calcareous nannofossils from the North Atlantic (Leg 48). In Montadert, L., Roberts, D. G., et al., Init. Repts. DSDP, 48: Washington (U.S. Govt. Printing Office), 589-640.

Ness, G., Levi, S., and Couch, R., 1980. Marine magnetic anomaly time-scales for the Cenozoic and Late Cretaceous: A précis, critique and synthesis. Rev. Geophys. Space Phys., 18:753-770. 
Perch-Nielsen, K., 1968. Der Feinbau und die Klassifikation der Coccolithen aus dem Maastrichtien von Dänemark. Det Kongelige Danske Videnskabernes Selskab, Biologiske Skrifter, 16:1-96. 1972. Remarks on Late Cretaceous to Pleistocene Coccoliths from the North Atlantic. In Laughton, A. S., Berggren, W. A., et al., Init. Repts. DSDP, 12: Washington (U.S. Govt. Printing Office), 1003-1070.

1977. Albian to Pleistocene calcareous nannofossils from the western south Atlantic, DSDP Leg 39. In Supko, P. R., PerchNielsen, K., et al., Init. Repts. DSDP, 39: Washington (U.S. Govt. Printing Office), 699-823.

1979. Calcareous nannofossils from the Cretaceous between the North Sea and the Mediterranean. In Aspekte der Kreide Europas. IUGS Ser. A, pp. 223-272.

Pflaumann, U., and Čepek, P., 1982. Cretaceous foraminiferal and nannoplankton biostratigraphy and paleoecology along the West African Continental Margin. In von Rad, U., Hinz, K., Sarnthein, M., and Seibold, E. (Eds.), Geology of the Northwest African Continental Margin: Berlin, Heidelberg, New York (Springer-Verlag), pp. 309-353.

Prins, B., 1977. Meeting on mid-Cretaceous nannofossils. Working Papers (quoted in Crux, 1982). The Hague.

Prins, B., and Perch-Nielsen, K., 1977. In Manivit, H., Perch-Nielsen, K., Prins, B., and Verbeek, J. W. (Eds.), Mid-Cretaceous Calcareous Nannofossil Biostratigraphy: Amsterdam, Proc. Kon. Ned. Akad. Wet., Ser. B, 80(3):169-181.

Prins, B., and Sissingh, W., 1977. Biostratigraphy of Cretaceous calcareous nannoplankton. Geol. Mijnbouw, 56(1):37-65. (Appendix)

Proto Decima, F., Medizza, F., and Todesco, L., 1978. Southeastern Atlantic Leg 40 calcareous nannofossils. In Bolli, H. M., Ryan, W. B. F., et al., Init. Repts. DSDP, 40: Washington (U.S. Govt. Printing Office), 571-634.

Roth, P. H., 1973. Calcareous nannofossils-Leg 17, Deep Sea Drilling Project. In Winterer, E. L., Ewing, J. I., et al., Init. Repts. DSDP, 17: Washington (U.S. Govt. Printing Office), 695-795.

, 1978. Cretaceous nannoplankton biostratigraphy and oceanography of the northwestern Atlantic Ocean. In Benson, W. E., Sheridan, R. E., et al., Init. Repts. DSDP, 44: Washington (U.S. Government Printing Office), 731-759.

Ryan, W. B. F., Bolli, H. M., Foss, G. N., Natland, J. H., Hottman, W. E., and Foresman, J. B., 1978. Objectives, principal results, operations, and explanatory notes of Leg 40, South Atlantic. In Bolli, H. M., Ryan, W. B. F., et al., Init. Repts. DSDP, 40: Washington (U.S. Govt. Printing Office), 5-28.

Schneidermann, N., 1973. Pelagic limestones in the central Caribbean. In Edgar, N. T., Saunders, J. B., et al., Init. Repts. DSDP, 15: Washington (U.S. Govt. Printing Office), 773-794.

Sissingh, W., 1977. Biostratigraphy of Cretaceous calcareous nannoplankton. Geol. Mijnbouw, 56(1):37-65.

Steinmetz, J. C., 1979. Calcareous nannofossils from the North Atlantic Ocean, Leg 49, Deep Sea Drilling Project. In Luyendyk, B.
P., Cann, J. R., et al., Init. Repts. DSDP, 49: Washington (U.S. Govt. Printing Office), 519-532.

Stradner, H., 1961. Vorkommen von Nannofossilien im Mesozoikum und Alttertiär. Erdöl Z., 77:77-88.

1963. New contributions to Mesozoic stratigraphy by means of nannofossils. 6th World Pet. Congr., Frankfurt, 4:167-184.

Stradner, H., and Adamiker, D., 1966. Nannofossilien aus Bohrkernen und ihre elektronenmikroskopische Bearbeitung. Erdöl-Erdgas $Z$. $82: 330-341$.

Taylor, R. J., 1982. Lower Cretaceous (Ryazanian to Albian) calcareous nannofossils. In Lord, A. R., (Ed.), A Stratigraphical Index of Calcareous Nannofossils: Chichester (Ellis Horwood Ltd.), Brit. Micropalaeontol. Soc. Ser..

Thierstein, H. R., 1971. Tentative Lower Cretaceous calcareous nannoplankton zonation. Eclogae Geol. Helv., 64:459-488. 1973. Lower Cretaceous calcareous nannoplankton biostratigraphy. Abh. Geol. Bundesanst. Wein, 29:1-52. 1974. Calcareous nannoplankton: Leg 26, Deep Sea Drilling Project. In Davies, T. A., Luyendyk, B. P., et al., Init. Repts. DSDP, 26: Washington (U.S. Govt. Printing Office), 619-667. 1976. Mesozoic calcareous nannoplankton biostratigraphy of marine sediments. Mar. Micropaleontol., 1:325-362.

1981. Late Cretaceous nannoplankton and the change at the Cretaceous-Tertiary boundary. Soc. Econ. Paleontol. Mineral. Spec. Publ., 32:355-394.

Thierstein, H. R., and Okada, H., 1979. The Cretaceous/Tertiary boundary event in the North Atlantic. In Tucholke, B. E., Vogt, P. R., et al., Init. Repts. DSDP, 43: Washington (U.S. Govt. Printing Office), 601-616.

van Hinte, J. E., 1976. A Cretaceous time scale. Am. Assoc. Ital/Petrol. Geol. Bull., 60(4):498-516.

Verbeek, J. W., 1976. Upper Cretaceous calcareous nannoplankton in a composite section near El Kef, Tunisia, I and II. Proc. Kon. Ned. Akad. Wet., Ser. B, 79:129-148.

1977. Calcareous nannoplankton biostratigraphy of Middle and Upper Cretaceous deposits in Tunisia, Southern Spain and France. Utrecht Micropaleont. Bull., 16:1-157.

Verbeek, J. W., and Manivit H., 1977. In Manivit H., Perch-Nielsen K., Prins B., and Verbeek J. W.: Mid Cretaceous Calcareous Nannofossil Biostratigraphy. Proc. Kon. Ned. Akad. Wet., Amsterdam, Ser. B, 80(3):169-181.

Wise, S. W., and Wind, F. H., 1976. Mesozoic and Cenozoic calcareous nannoplankton recovered by DSDP Leg 36 drilling on the Falkland Plateau, southwest Atlantic sector of the Southern Ocean. In Barker, P. F., Dalziel, I. W. D., et al., Init. Repts. DSDP, 36: Washington (U.S. Govt. Printing Office), 269-492.

Wood, C. J., 1982. The biostratigraphy of Aucellina in Albian-Cenomanian successions. 2nd Kreide Symp. München, 90-91. (Abstract)

Worsley, T. R., 1974. The Cretaceous-Tertiary boundary event in the ocean. In Hay, W. W. (Ed.), Studies in Paleo-oceanography. Soc. Econ. Paleontol. Mineral. Spec. Publ., 20:94-125. 
APPENDIX

List of Species Cited in Alphabetical Order by Species Epithet

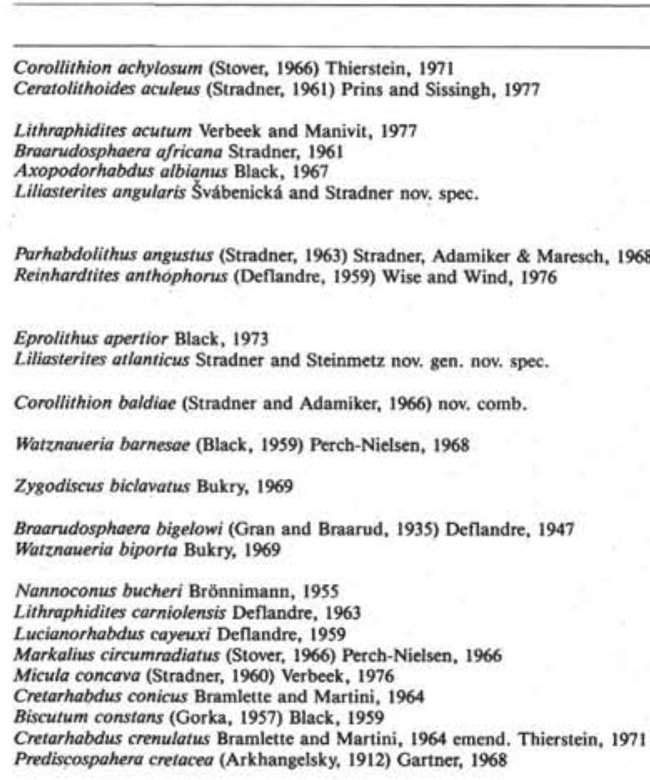

Arkhangelskiella cymbiformis Vekshina, 1959

Microrhabdulus decoratus Deflandre, 1959

Tetrapodorhabdus decorus (Deflandre and Fert, 1954) Wind and Wise, 1976

Zygodiscus diplogrammus (Deflandre and Fert, 1954) Gartner, 1968

Cribrosphaerella ehrenbergi (Arkhangelsky, 1912) Deflandre, 1952

Parnabdolithus embergeri (Noē, 1958) Stradner, 1963

Broinsonia enormis (Shumenko, 1968) Manivit, 1971 Eiffellithus eximius (Stover, 1966) Perch-Nielsen, 1968

Lithastrinus floralis Stradner, 1962

Scapholithus fossilis Deflandre and Fert, 1954

Marthasterites furcatus (Deflandre and Fert, 1959) Deflandre, 1959

Marthasterites furcatus crassus Deflandre, 1977

Tranolithus gabalus Stover, 1966

Cribrocorona gallica (Stradner, 1963) Bramlette and Martini, 1964

Quadrum gartneri Prins and Perch-Nielsen, 1977

Nannoconus globulus Brönnimann, 195

Quadrum gothicum (Deflandre, 1959) Prins and Perch-Nielsen, 1977 Prediscosphoera grandis Perch-Nielsen, 1979

Lithastrinus grilli Stradner, 1962

Bukryaster hayi (Bukry 1969) Prins, 197
Appendix. (Continued).

\begin{tabular}{|c|c|c|}
\hline & Plate & Figure \\
\hline \multicolumn{3}{|l|}{$\begin{array}{l}\text { Microrhabdulus helicoides Deflandre, } 1959 \\
\text { Braarudosphaera hoschulzi Reinhardt, } 1966\end{array}$} \\
\hline \\
\hline & & \\
\hline \multicolumn{3}{|l|}{ Markalius inversus (Deflandre and Fert, 1954) Bramlette and Martini, 1964} \\
\hline \multicolumn{3}{|l|}{$\begin{array}{l}\text { Ceratolithoides kamptreri Bramlette and Martini, } 1964 \\
\text { Stephanolithion laffitei Noel, } 1970\end{array}$} \\
\hline Reinhardtites levis Prins and Sissingh, 1977 & 42 & 8 \\
\hline \multirow[t]{2}{*}{ Chiastozygus litterarius (Gorka, 1957) Manivit, 1971} & 35 & 1 \\
\hline & 48 & $1-6$ \\
\hline \multicolumn{3}{|l|}{ Arkhangelskiella magnacava Gartner, 1968} \\
\hline \multirow{2}{*}{\multicolumn{3}{|c|}{$\begin{array}{l}\text { Kamptnerius magnificus Deflandre, } 1959 \\
\text { Prediscosphaera majungae Perch-Nielsen, } 1974\end{array}$}} \\
\hline & $\begin{array}{l}39 \\
40\end{array}$ & $\begin{array}{l}2-4, ? 1 \\
8-10\end{array}$ \\
\hline Staurolithites matalosus (Stover, 1966) Čepek and Hay, 1969 & 48 & $9-12$ \\
\hline Reinhardtites mirabilis Perch-Nielsen, 1968 & 41 & 3,4 \\
\hline Lithastrinus moratus Stover, 1966 & 20 & $1,2,5$ \\
\hline Micula murus (Martini, 1961) Bukry, 1973 & 30 & $2,3,5,6$ \\
\hline \multirow{2}{*}{\multicolumn{3}{|c|}{$\begin{array}{l}\text { Quadrum nitidum (Martini, 1961) Prins and Perch-Nielsen, } 1977 \\
\text { Gartnerago obliquum (Stradner, 1963) Reinhardt, } 1970\end{array}$}} \\
\hline & 17 & \\
\hline \multirow{2}{*}{\multicolumn{3}{|c|}{$\begin{array}{l}\text { Ahmuellerella octoradiata (Gorka, 1957) Reinhardt, } 1966 \\
\text { Thorecosphaera operculata Bramlette and Martini, } 1964\end{array}$}} \\
\hline & & \\
\hline \multirow{2}{*}{ Tranolithus orionatus Stover, 1966} & 45 & 1 \\
\hline & 48 & 7 \\
\hline \multirow[t]{3}{*}{ Broinsonia parca (Stradner, 1963) Bukry, 1969} & 2 & $1-4$ \\
\hline & 3 & 4-9 \\
\hline & 4 & $1-4$ \\
\hline Manivitella pemmatoidea (Deflandre, 1965) Thierstein, 1971 & $\begin{array}{l}28 \\
51\end{array}$ & $3^{1-6}$ \\
\hline Micula praemurus (Bukry, 1973) nov. comb. & 31 & 4,7 \\
\hline \multicolumn{3}{|l|}{ Seribiscutum primitivum (Thierstein, 1974) Filewicz, Wise and Wind, 1976} \\
\hline Micula prinsii Perch-Nielsen, 1979 & 29 & $1-4$ \\
\hline & 30 & $1,4,7$ \\
\hline & 27 & $1,2,7$ \\
\hline & 42 & 1,2 \\
\hline Cylindralithus sculptus Bukry, 1969 & 13 & $1-7$ \\
\hline Gartnerago segmentatum (Stover, 1966) Thierstein, 1974 & 18 & 1,2 \\
\hline Lithostrinus septenarius Forchheimer, 1972 & 21 & \\
\hline Cylindralithus serratus Bramlette and Martini, 1964 & 12 & $1-7$ \\
\hline Corollithion signum Stradner, 1963 & 7 & 6,7 \\
\hline Zygodiscus sisyphus Gartner, 1968 & & \\
\hline \multirow[t]{3}{*}{ Prediscosphaera spinosa (Bramlette and Martini, 1964) Gartner, 1968} & 35 & 8 \\
\hline & 36 & \\
\hline & 48 & 13,14 \\
\hline \multirow{3}{*}{ Zygodiscus spiralis Bramlette and Martini, 1964} & 46 & \\
\hline & 48 & 15,16 \\
\hline & 49 & 6,7 \\
\hline \multirow[t]{2}{*}{ Micula staurophora (Gardet, 1955) Stradner, 1963} & \multicolumn{2}{|c|}{ Parhabdolithus splendens (Deflandre, 1953) Noel, 1969} \\
\hline & 32 & $1-3$ \\
\hline Microrhabdulus stradneri Bramlette and Martini, 1964 & 27 & 5,6 \\
\hline Vekshinella stradneri Rood, Hay and Barnard, 1971 & 48 & 8 \\
\hline \multirow[t]{2}{*}{ Gartnerago striatum (Stradner, 1963) Forchheimer, 1972} & 18 & 9. 10 \\
\hline & 19 & \\
\hline Micula swastica (Prins, 1977) Stradner and Steinmetz nov, spec. & 31 & $3,5,6$ \\
\hline Zygodiscus theta (Black, 1959) Bukry, 1969 & 45 & \\
\hline Helicolithus trabeculatus (Gorka, 1957) Verbeek, 1977 & 16 & $1-7$ \\
\hline Quadrum trifidum (Stradner, 1961) Prins and Perch-Nielsen, 1977 & 33 & 1. 2, 5, 6 \\
\hline Nannoconus truitti Brönnimann, 1955 & si & 4-6 \\
\hline Eiffellithus turriseiffeli (Deflandre and Fert, 1954) Reinhardt, 1965 & 15 & $1-6$ \\
\hline Ceratolithoides verbeekii Perch-Nielsen, 1979 & & \\
\hline Heteromarginatus wallacei Bukry, 1969 & 47 & 6,7 \\
\hline
\end{tabular}




\section{NOTE TO PLATES 1-52}

The purpose of providing plates of the majority of nannofossil species found in the Cretaceous section of Hole 530A is the obvious one of showing what the species we are talking about actually look like. In the case of Hole 530A, only very few Cretaceous samples are preserved in such a state that the nannofossil specimens appearing on the screen of the scanning electron microscope (SEM) are worth photographing. Since most biostratigraphic work was done with a light microscope of high resolution, light-microscopic photographs of the nannofossil species have been added for many species. The following abbreviations are used to indicate the methods used for illustration: $\mathrm{NL}=$ light microscope, normal light; $\mathrm{PHC}=$ light microscope, phase contrast; $\mathrm{XN}=$ light microscope, polarized light, $\mathrm{TEM}=$ transmission electron microscope; $\mathrm{SEM}=$ scanning electron microscope.

All of the negatives are deposited at the ELMI-Laboratory of the Geological Survey of Austria in Vienna, where the micrographs were produced by Herbert Stradner and Franz Allram. Instruments used were the Cambridge S 150, Philips EM 75 C, and Reichert Zetopan Pol. Film brand used was AGFA Agepan Professional 25. The layout and mounting of the plates were done in the ELMI-Lab in Vienna.

Some remarks about methods are appropriate here. Some nannofossils, especially those from the mid-Cretaceous black shales, are so transparent that only polarized light is likely to produce convincing photographs. In some cases we have used an additional gold-sputter (as for example Plate 20, Figures 1 and 2, or Plate 22, Figures 14) to add additional contrast. Usually photographs were taken only from samples cleaned through ultrasonication and repeated centrifugation. In slides prepared from cleaned samples there is no disturbing clay fraction. Where a rare specimen was found in an uncleaned sample (compare Plate 6, Figs. 4-6), it was photographed nevertheless, with the background speckled with organic debris.

The magnification of each picture can be calculated from the scale bar.

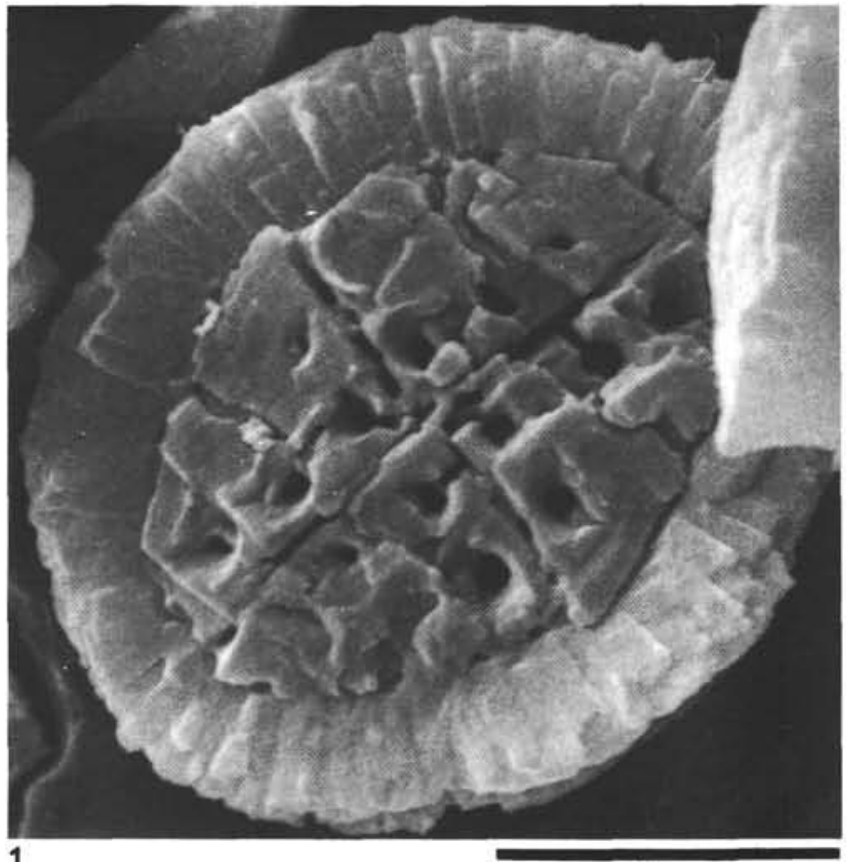

1
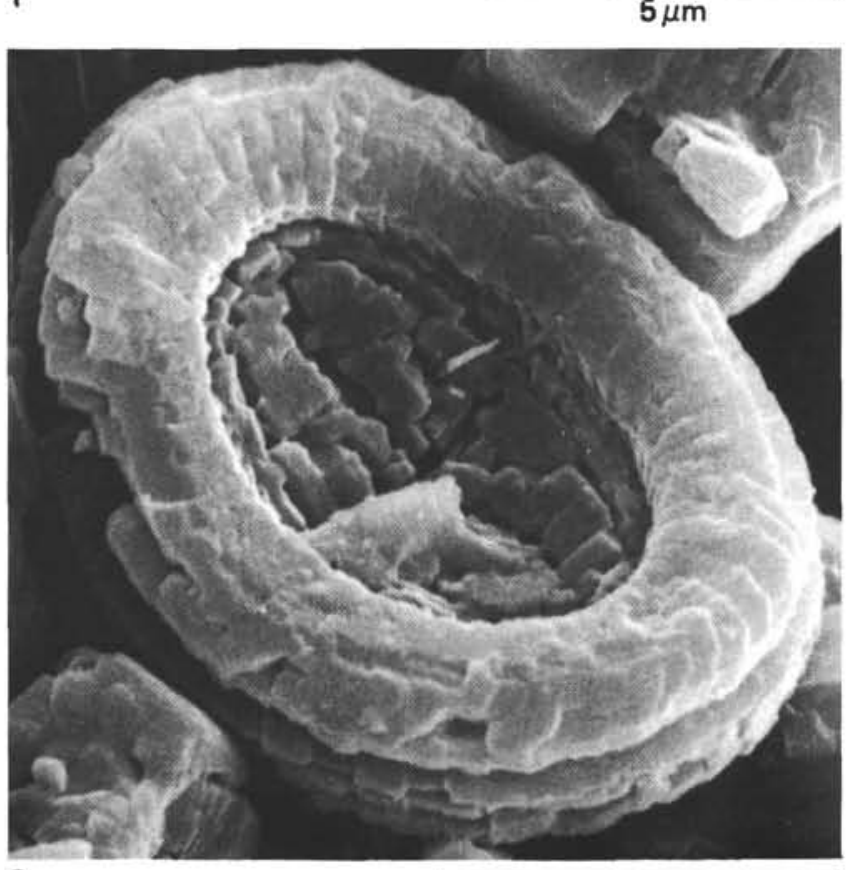

3

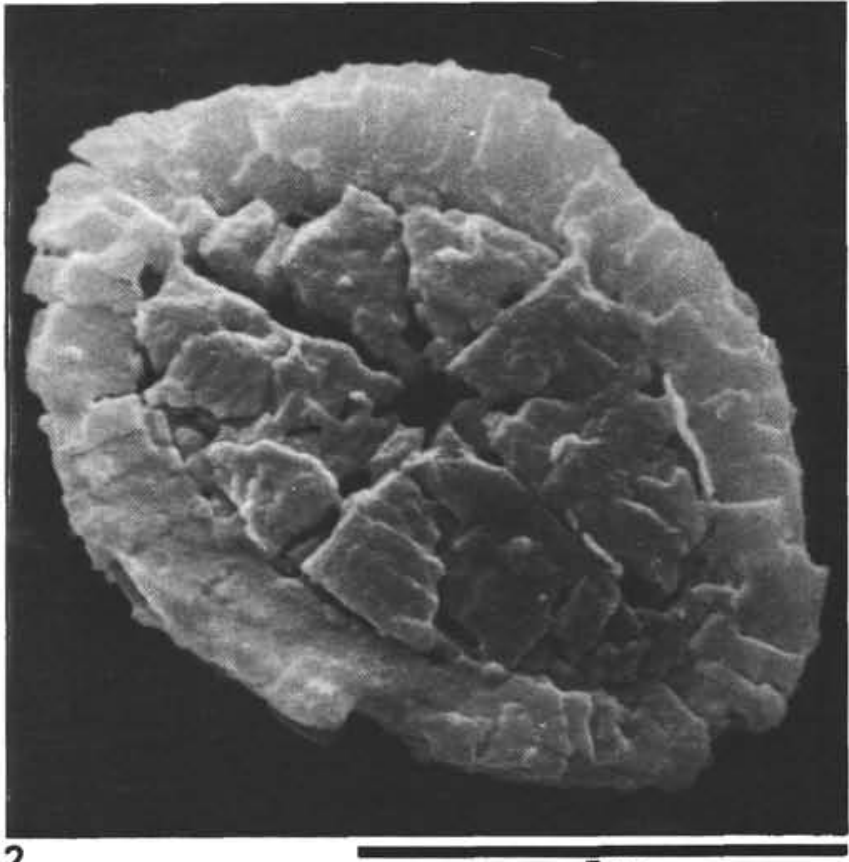

2

$5 \mu \mathrm{m}$



$5 \mu \mathrm{m}$

Plate 1. Arkhangelskiella cymbiformis Vekshina, 1959; SEM. 1. Distal view, Sample 530A-50-2, 13-14 cm. 2. Distal view, Sample 530A-50-2, $22-23 \mathrm{~cm}$. 3, 4. Oblique proximal and proximal view; Sample 530A-50-2,13-14 cm. Cretaceous/Tertiary boundary. 


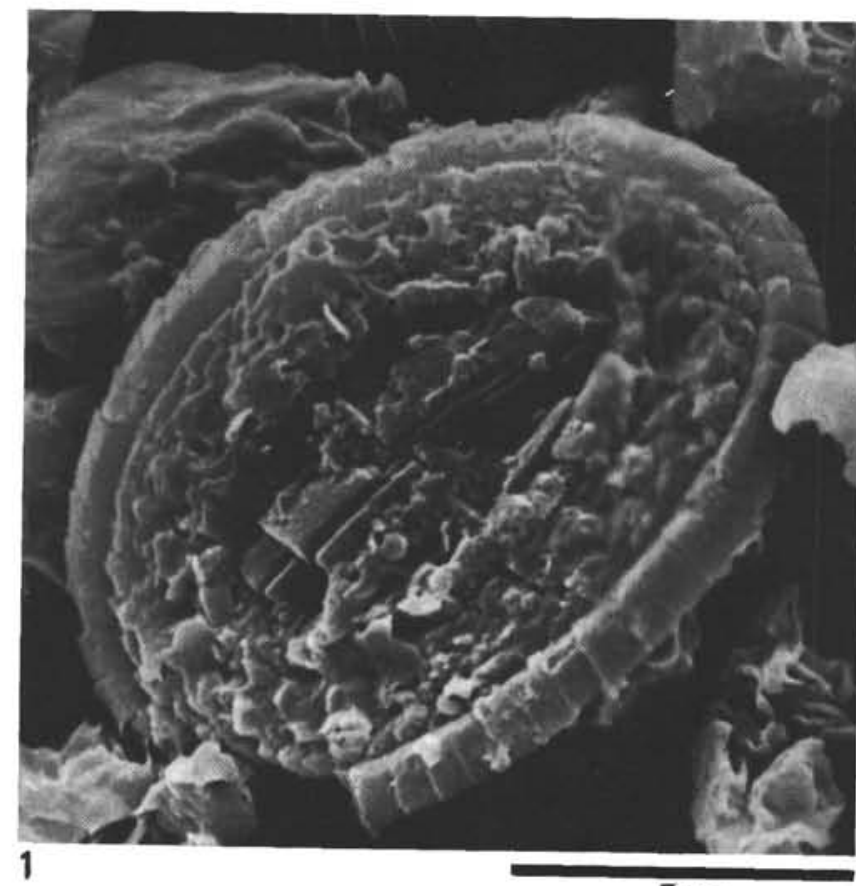

1



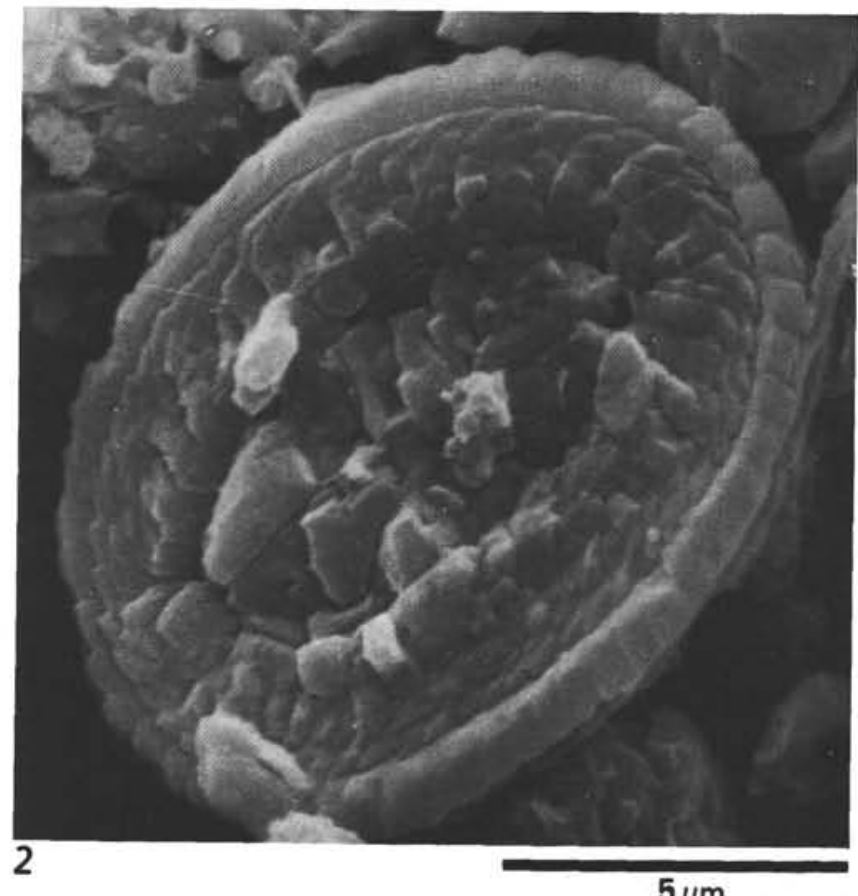

$5 \mu \mathrm{m}$

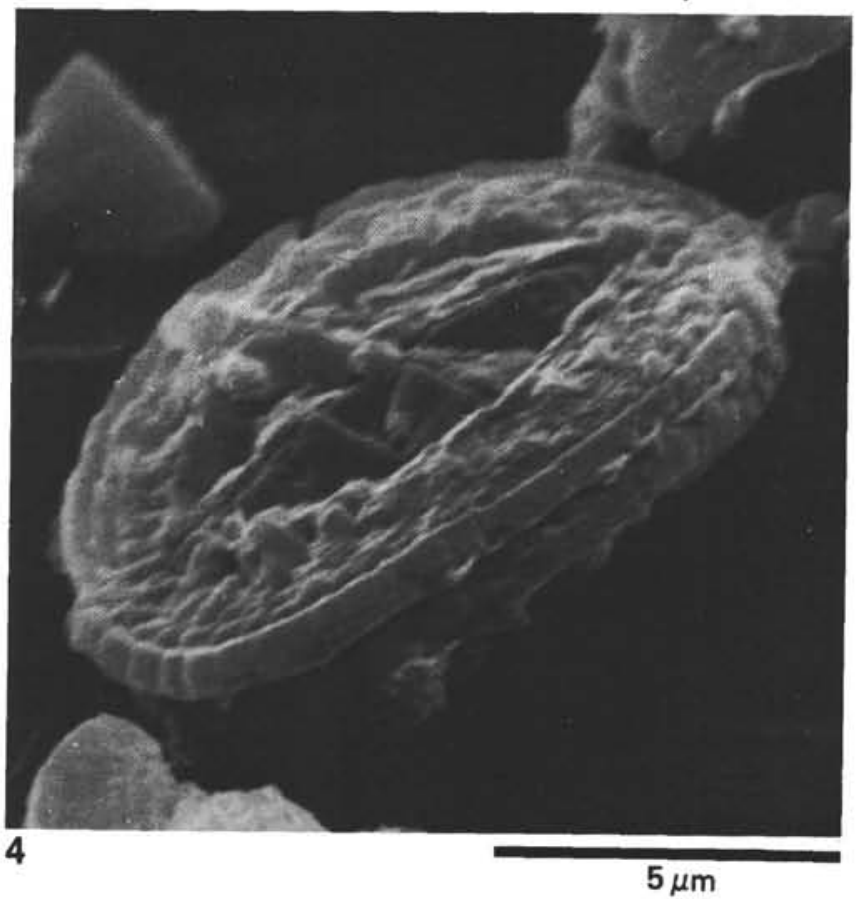

Plate 2. Broinsonia parca (Stradner, 1963) Bukry, 1969; SEM; distal view. 1. Sample 530A-76-5, 110-111 cm. 2. Sample 530A-77-2, 142-143 cm. 3. Sample $530 \mathrm{~A}-76-5,110-111 \mathrm{~cm}$. 4. Sample 530A-77-2, 142-143 cm. Lower Campanian. 


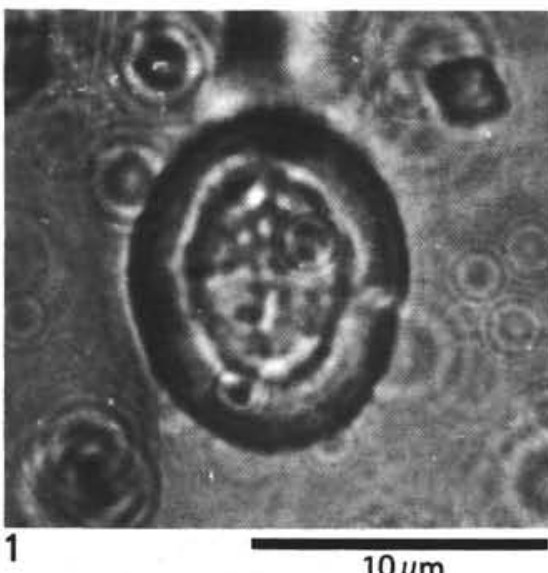

$10 \mu \mathrm{m}$

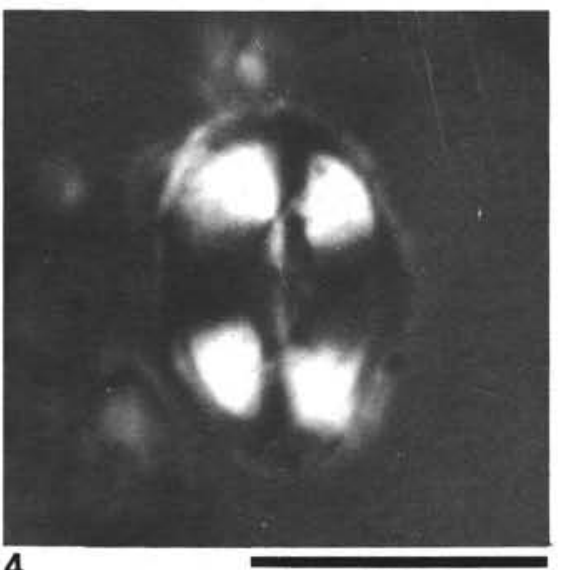

$10 \mu \mathrm{m}$

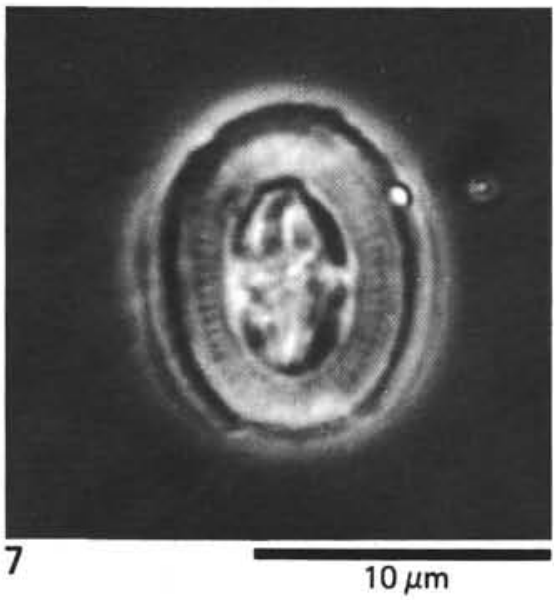

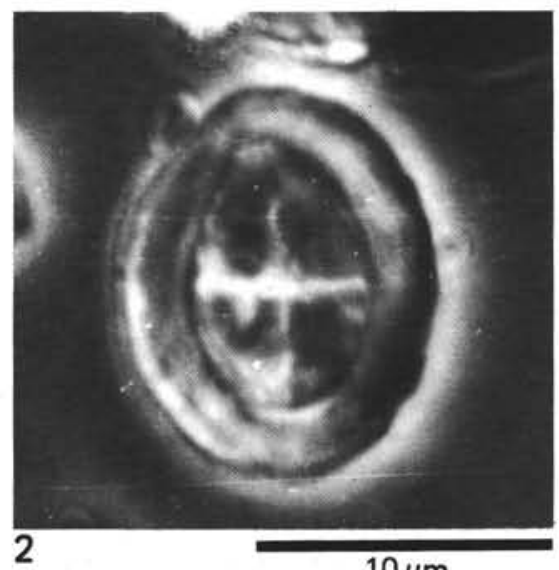

$10 \mu \mathrm{m}$



$10 \mu \mathrm{m}$



$10 \mu \mathrm{m}$
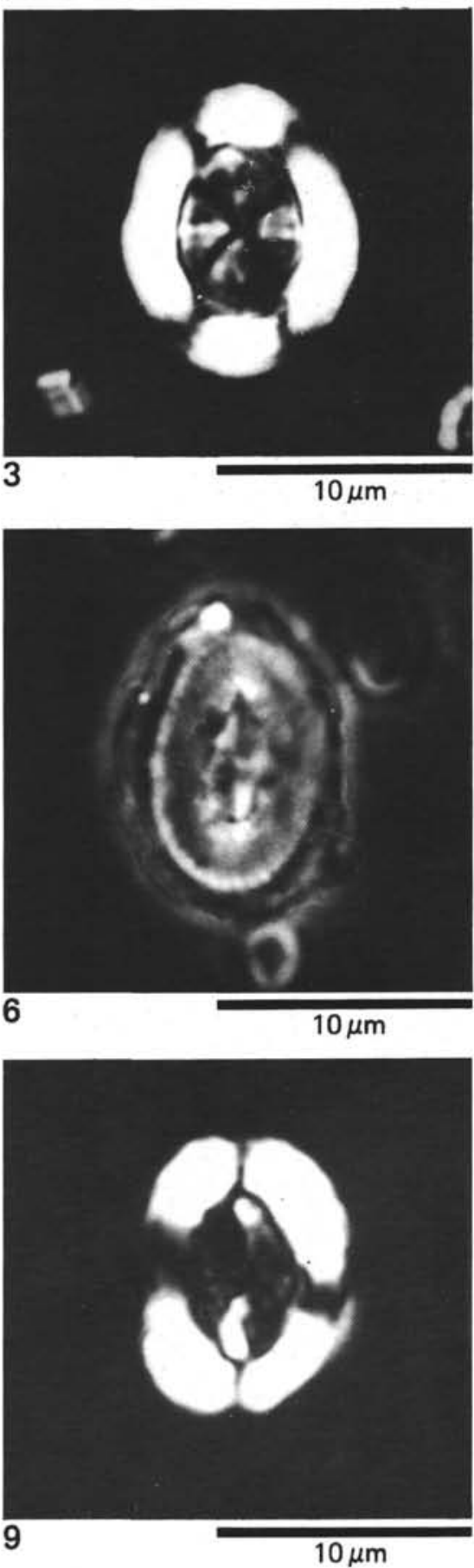

Plate 3. 1-3. Arkhangelskiella cymbiformis Vekshina, 1959. (1) Sample 530A-50-1, 16-17 cm; NL. (2) Sample 530A-50-1, 16-17 cm; PHC. (3) Sample 530A-50-1, 16-17 cm; XN. 4-9. Broinsonia parca (Stradner, 1963) Bukry, 1969. (4) Sample 530A-61-4, 62-63 cm; XN + gypsum plate. (5) Sample 530A-50-1, 16-17 cm; XN; reworked specimen; plane view. (6) Sample 530A-61-4, 62-63 cm; PHC. (7) Sample 530A-77-2, 142-143 cm; PHC. (8, 9) Sample 530A-77-2, 142-143 cm; XN. Cretaceous/Tertiary boundary (Core 530A-50); upper Campanian (Core 530A-61); lower Campanian (Core 530A-77). 

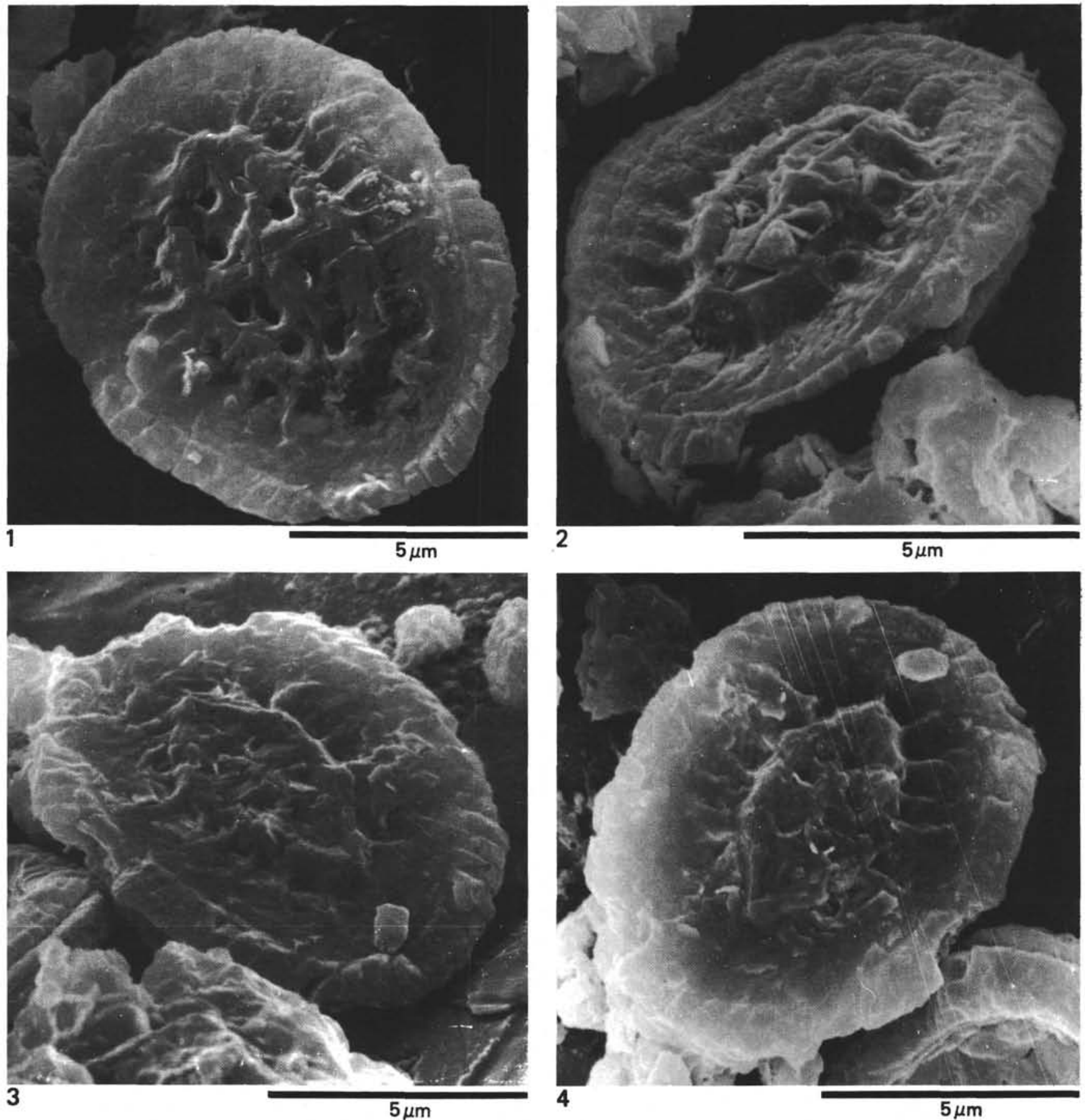

Plate 4. Broinsonia parca (Stradner, 1963) Bukry, 1969; SEM. 1-4. Distal and oblique distal views of lectotypes from the type-sample Perwang 1 , Rag, 2234-2239 m; upper Austria; upper Campanian. 


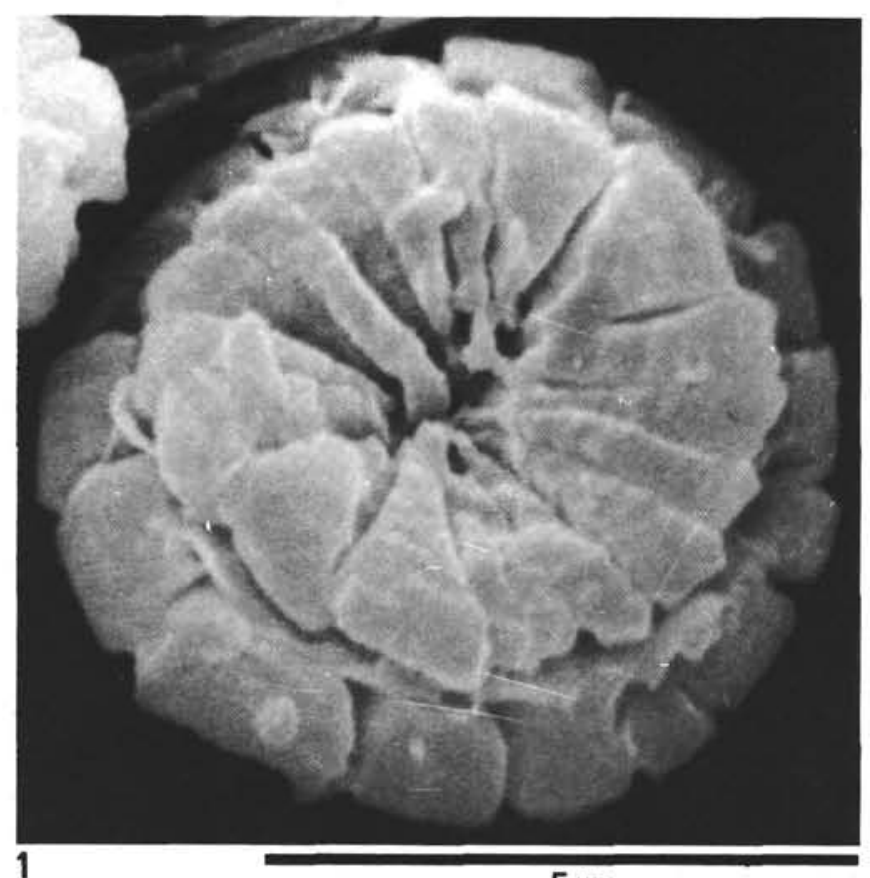

$5 \mu \mathrm{m}$



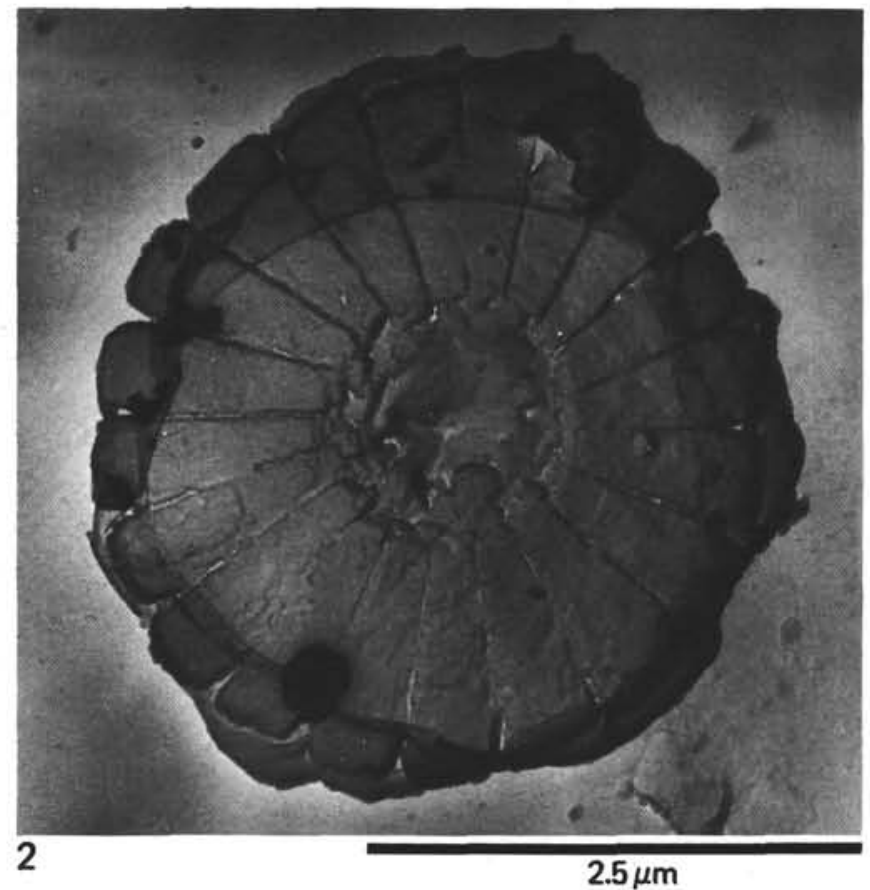

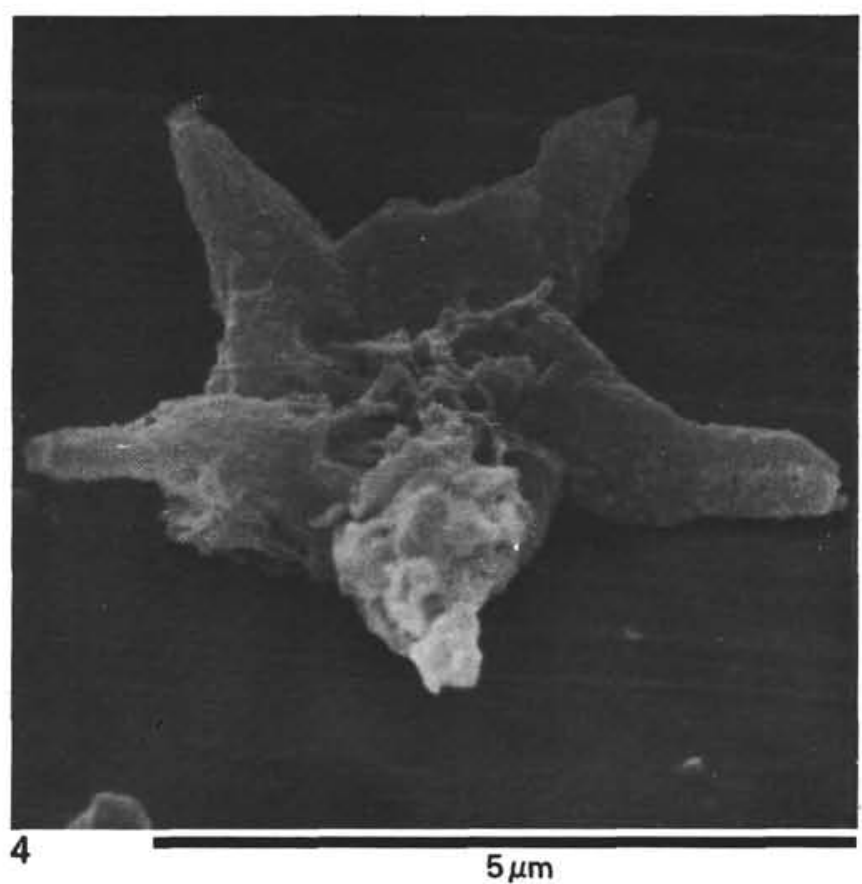

Plate 5. 1, 2. Biscutum constans (Gorka, 1957) Black, 1959. (1) Proximal view; Sample 530A-50-2, 13-14 cm; SEM; Cretaceous/Tertiary boundary. (2) Distal view; Sample 530A-78,CC; TEM; lower Campanian. 3, 4. Bukryaster hayi (Bukry, 1969) Prins, 1971; SEM. (3) Proximal view; Sample 530A-77-2, 142-143 cm. (4) Same specimen in oblique proximal view; lower Campanian. 


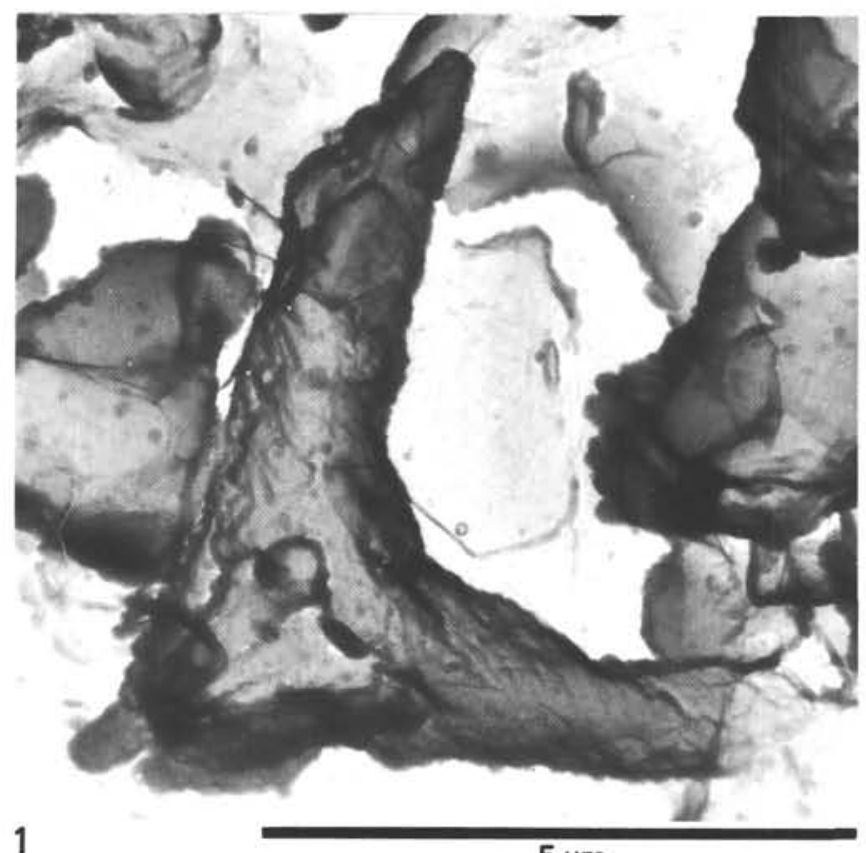

1
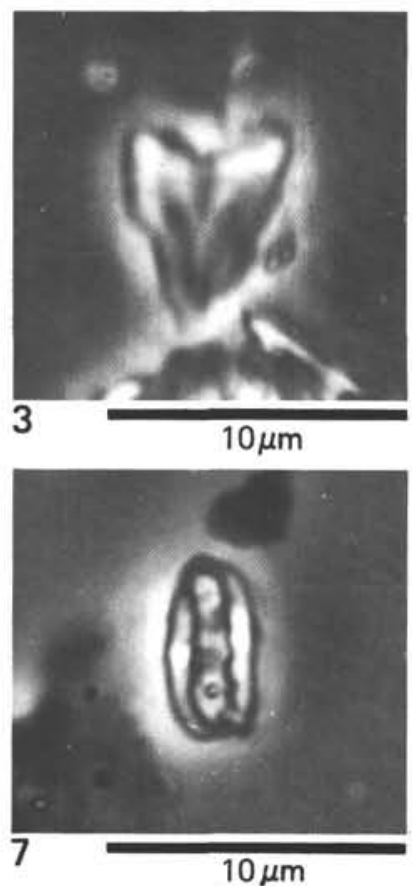

$5 \mu \mathrm{m}$


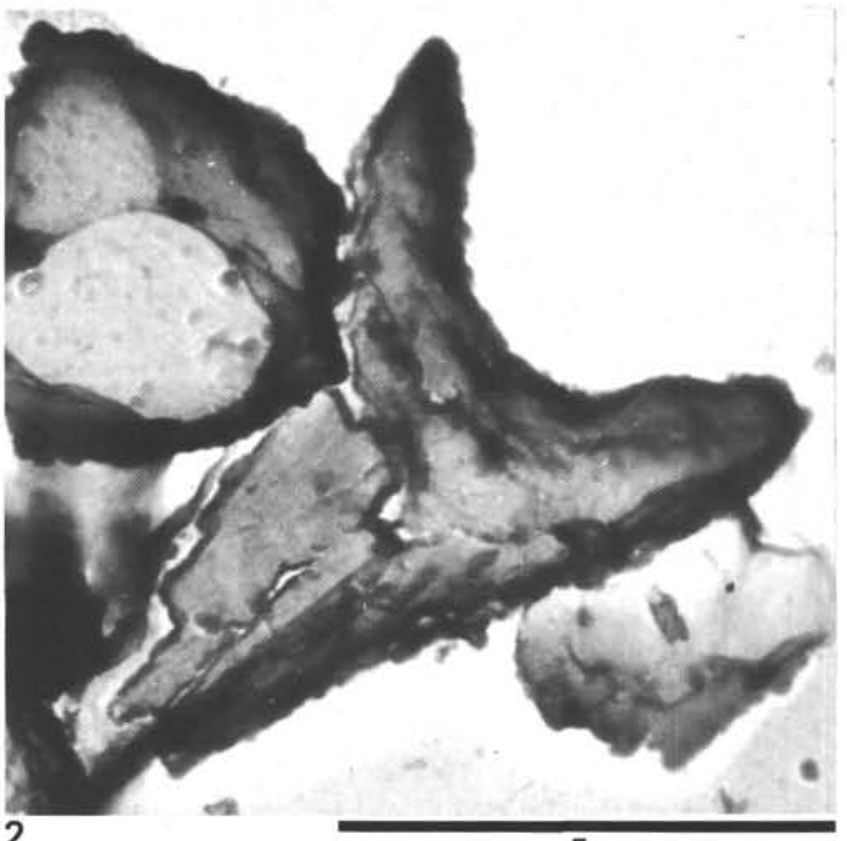

$5 \mu \mathrm{m}$
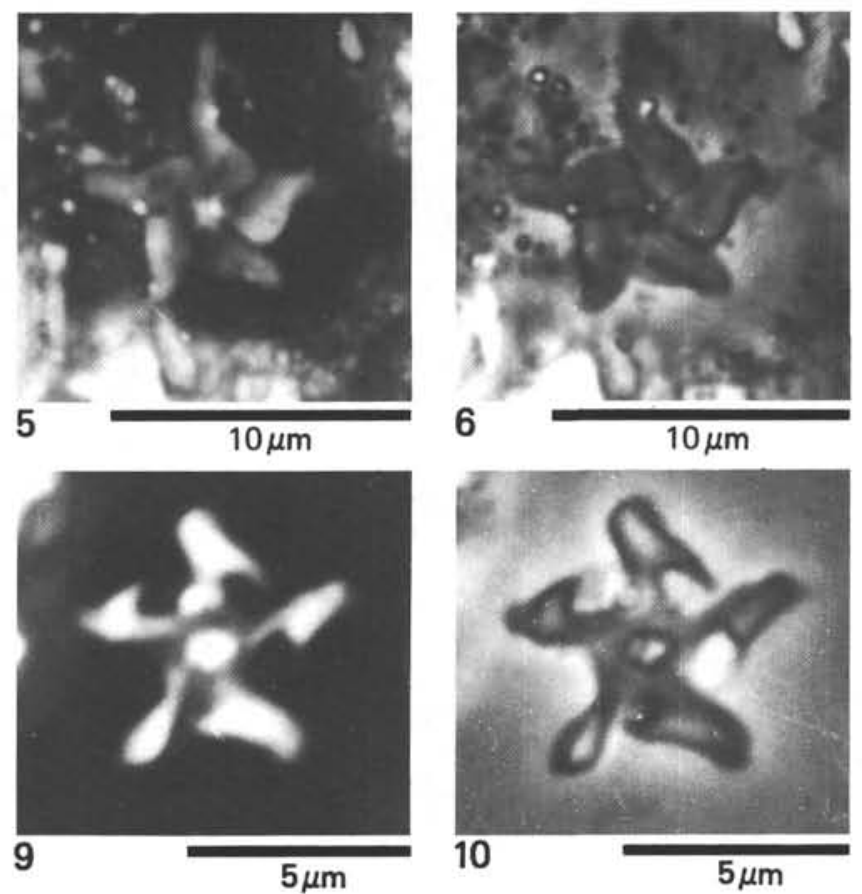

Plate 6. 1-3. Ceratolithoides aculeus (Stradner, 1961) Prins and Sissingh, 1977. (1, 2) Plane view of lectotypes from the type-sample nr. 86/19 from the flysch of the Vienna Woods; TEM. (3) Plane view; Sample 530A-61-4, 62-63 cm; PHC; upper Campanian. 4-6. Bukryaster hayi (Bukry, 1969) Prins, 1971; Plane views of proximal side; (4) XN. (5, 6) PHC. Sample 530A-77-2, 85-86 cm; lower Campanian. 7. Parhabdolithus angustus (Stradner, 1963) Stradner, Adamiker, and Maresch, 1968. Plane view; Sample 530A-100-2, 98-99 cm; PHC. late Cenomanian to early Turonian. 8-10. Bukryaster hayi (Bukry, 1969) Prins, 1971. Plane view of proximal side; corroded specimen. (8) XN. (9) Negative PHC. (10) Positive PHC. Sample 530A-77-2, 85-86 cm; lower Campanian. 


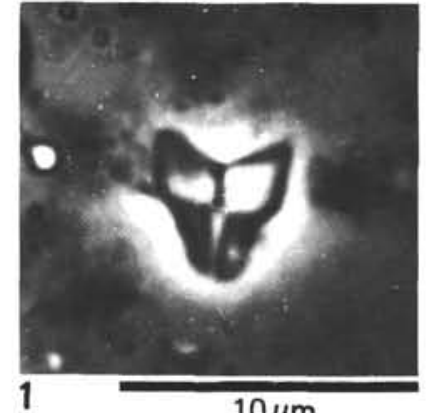

1
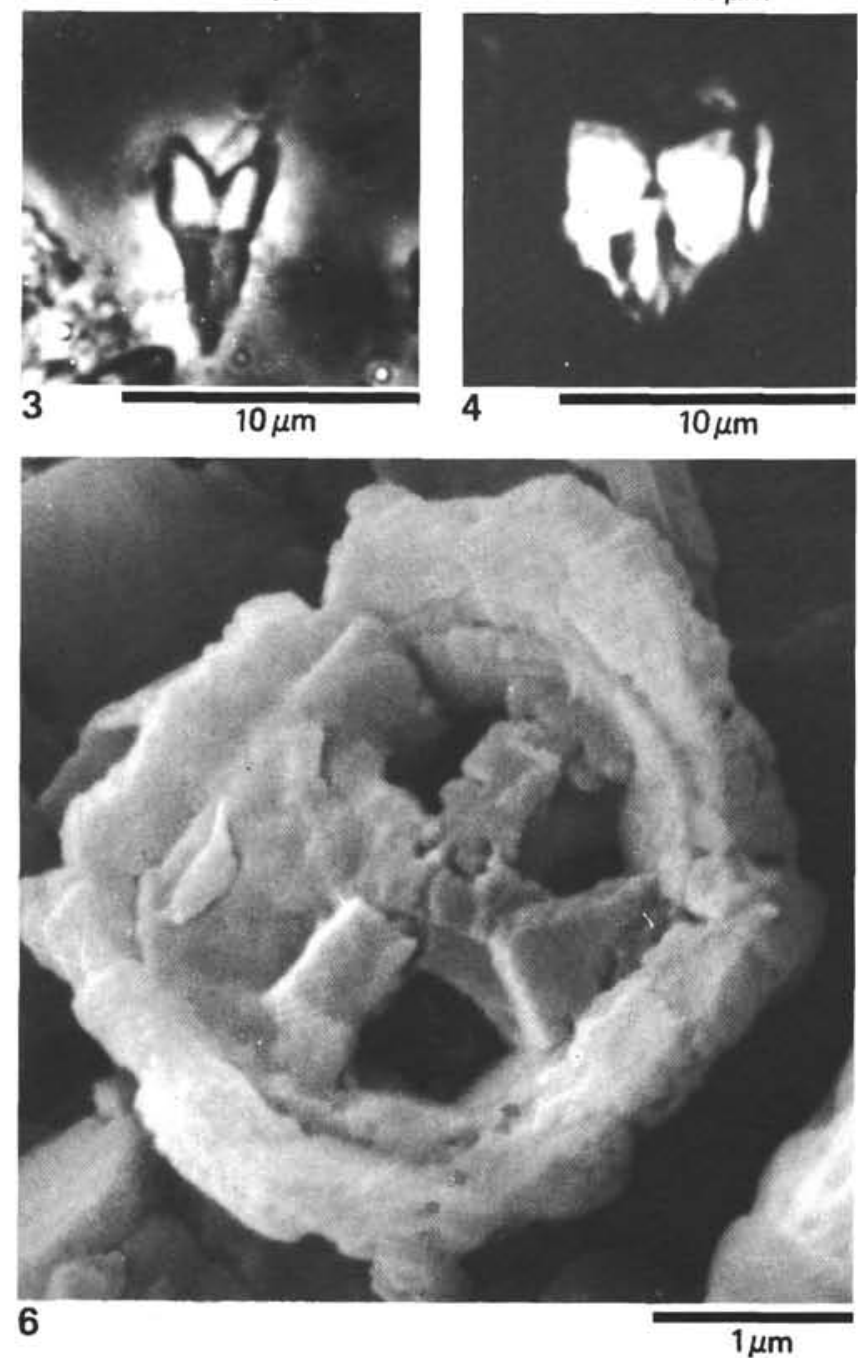
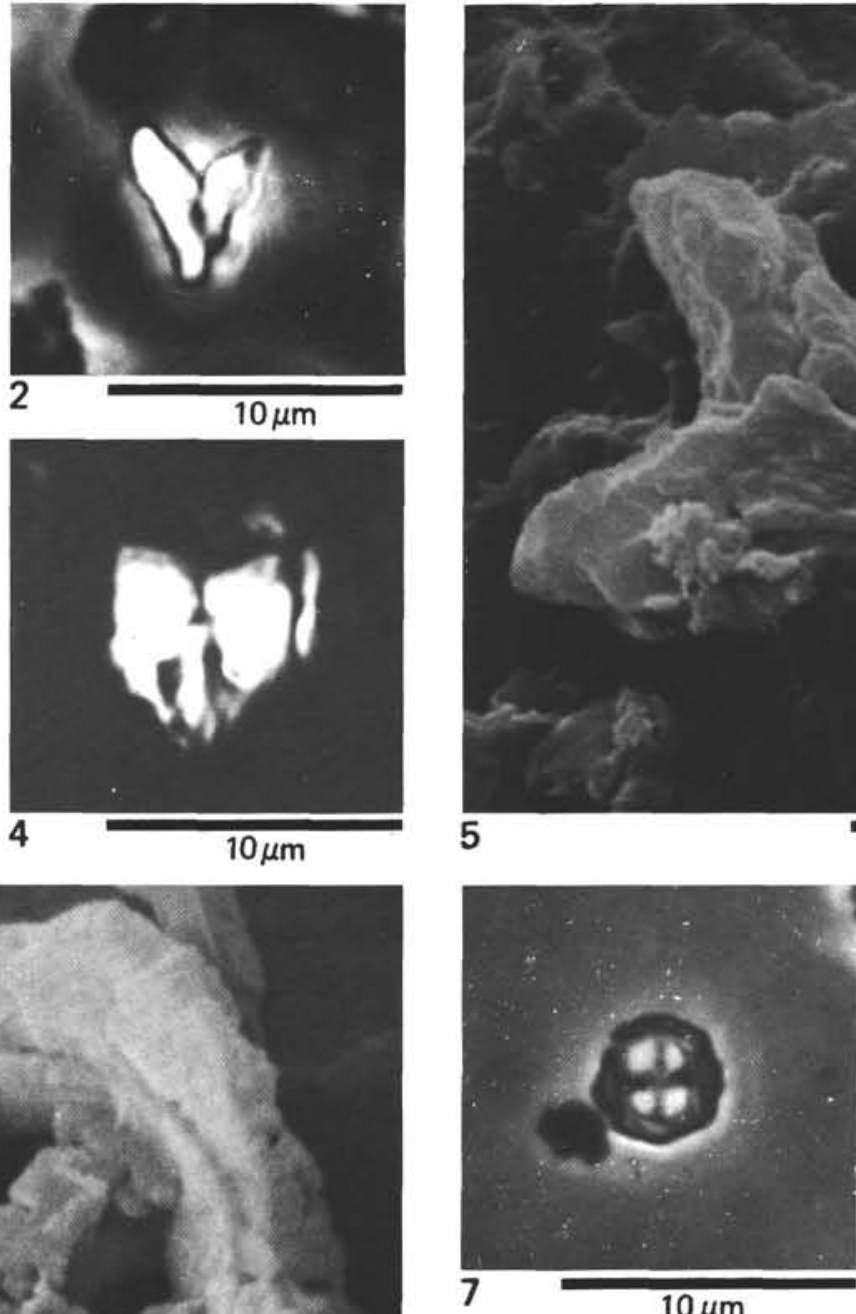

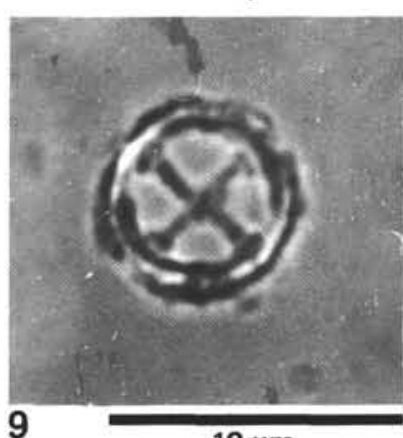

$10 \mu \mathrm{m}$

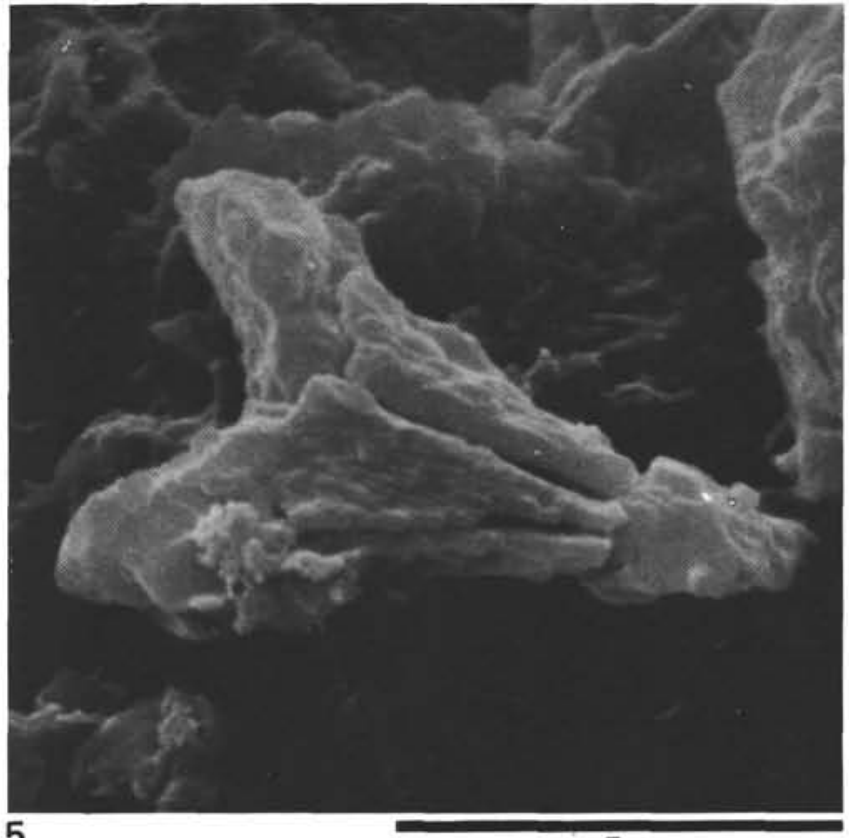

$5 \mu \mathrm{m}$
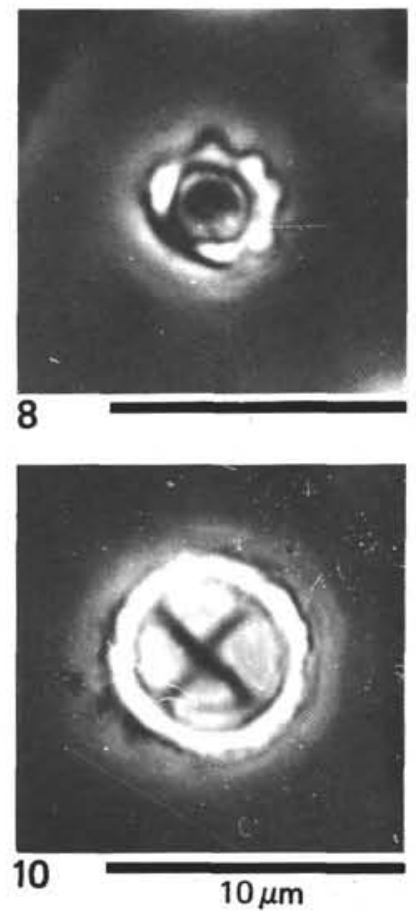

Plate 7. 1-5. Ceratolithoides aculeus (Stradner, 1961) Prins and Sissingh, 1977. (1, 3) Plane views; Sample 530A-61-4, 62-63 cm; PHC; upper Campanian. (2) Plane view; Sample 530A-57-2, 65-66 cm; PHC; lower Maestrichtian. (4) Plane view; Sample 530A-51-5, 43-44 cm; PHC; upper Maestrichtian. (5) Oblique plane view; Sample 530A-57-2, 65-66 cm; SEM; early Maestrichtian. 6, 7. Corollithion signum Stradner, 1963. (6) Distal view; Sample 530A-94-2, 87-88 cm; SEM; lower Coniacian. (7) Plane view; Sample 530A-77-2, 142-143 cm; PHC; lower Campanian. 8. Stephanolithion laffitei Noel, 1970; Plane view; Sample 530A-100-2, 98-99 cm; PHC; late Cenomanian to early Turonian. 9, 10. Corollithion baldiae (Stradner and Adamiker, 1966); Plane views; Sample 530A-94-2, 87-89 cm; NL and PHC; lower Coniacian. 




1 $10 \mu \mathrm{m}$

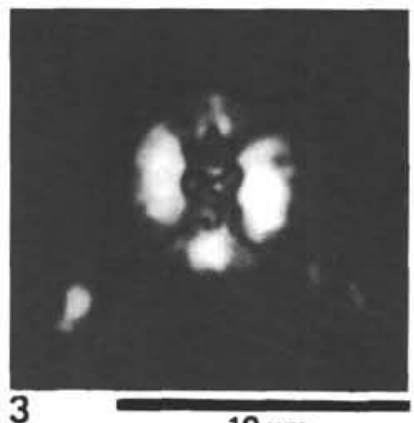

$10 \mu \mathrm{m}$

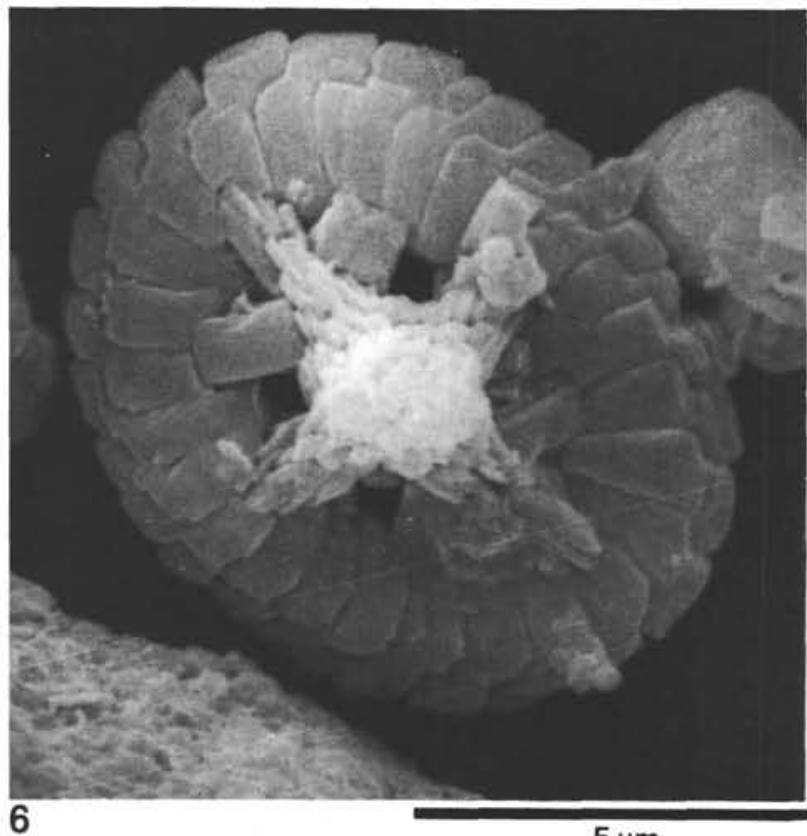

$5 \mu \mathrm{m}$

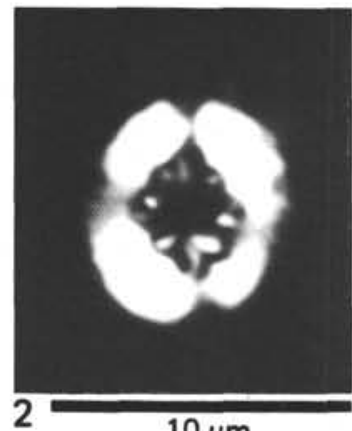

$10 \mu \mathrm{m}$

$10 \mu \mathrm{m}$



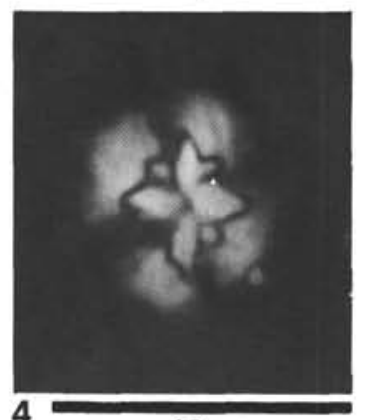

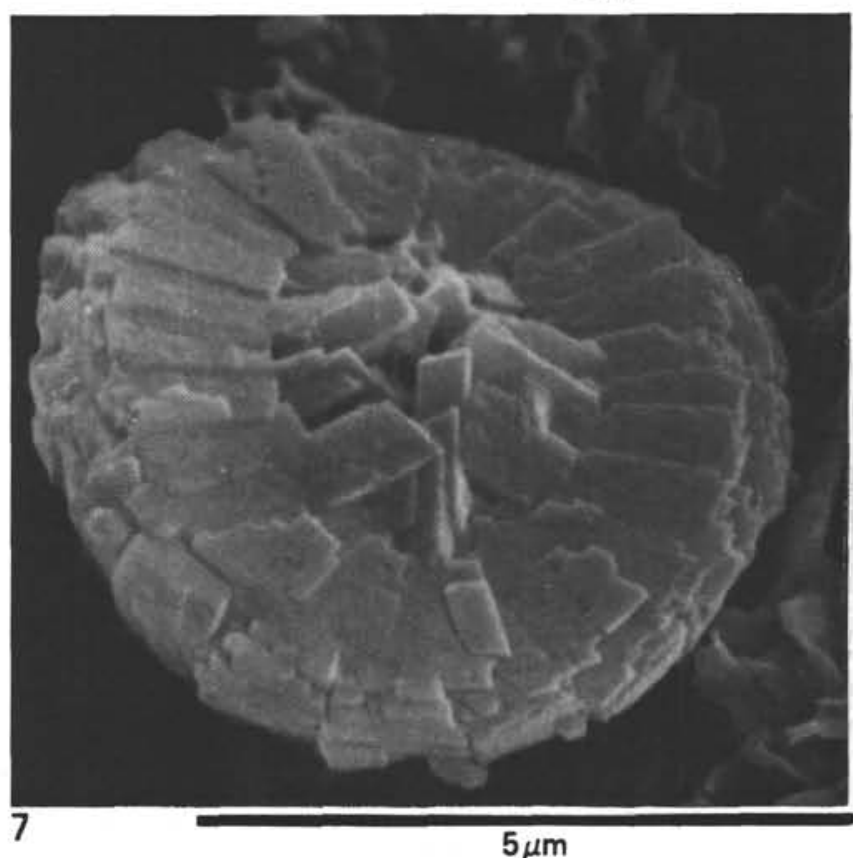

Plate 8. Cretarhabdus crenulatus Bramlette and Martini, 1964 emend. Thierstein, 1971. 1. Plane view; Sample 530A-94-2, 87-89 cm; XN; lower Coniacian. 2. Plane view; Sample 530A-51-1, 16-17 cm; XN; Cretaceous/Tertiary boundary. 3. Plane view; Sample 530A-78-3, 30-31 cm; XN; lower Campanian. 4. Plane view; Sample 530A-51-1, 16-17 cm; XN; Cretaceous/Tertiary boundary. 5. Distal view; Sample 530A-52-2, 13-14 cm; SEM; Cretaceous/Tertiary boundary. 6. Distal view; Sample 530-A-77-2, 142-143 cm; SEM; lower Campanian. 7. Oblique distal view; Sample 530A-50-1, 16-17 cm; SEM; Cretaceous/Tertiary boundary. 

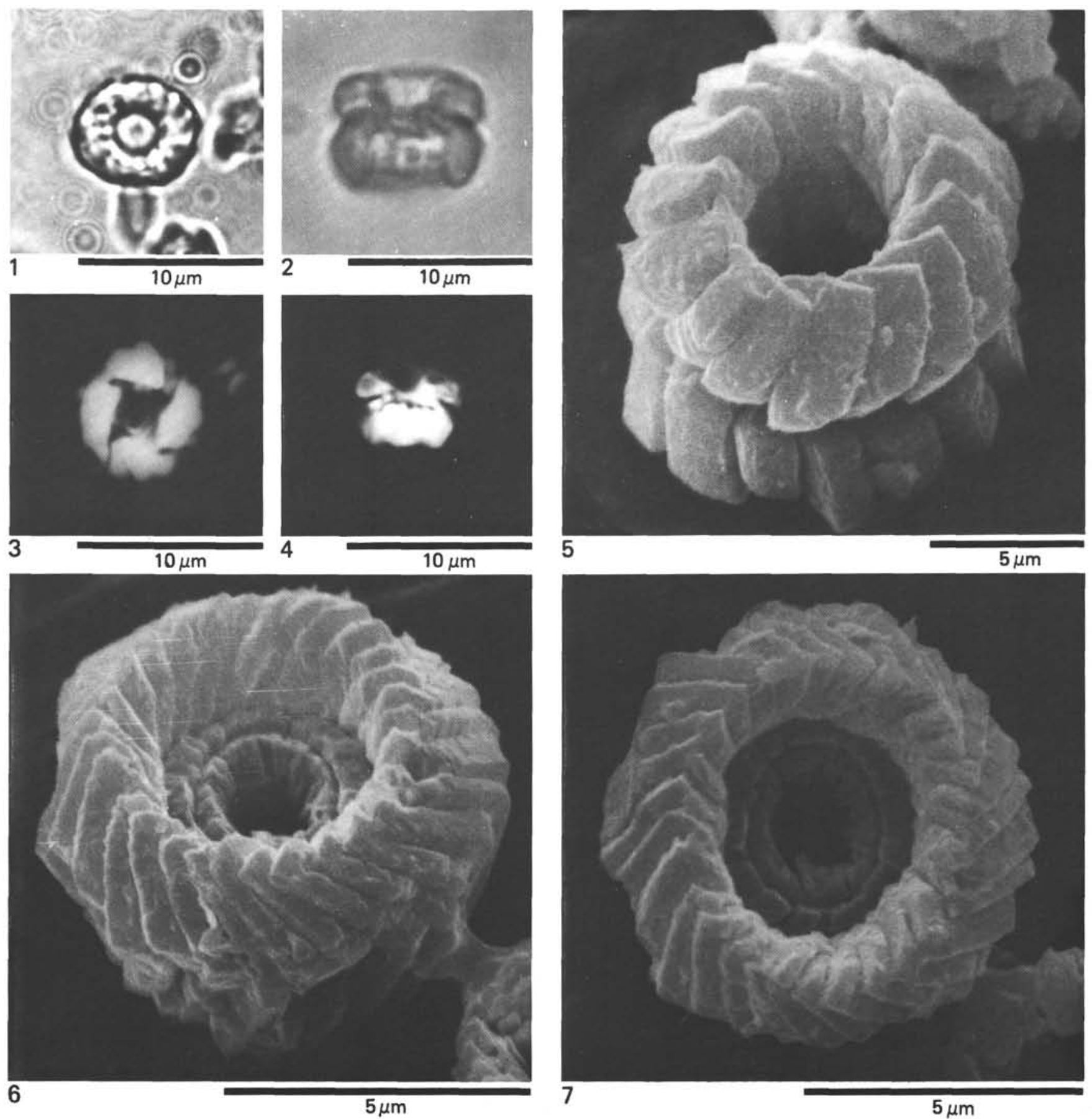

Plate 9. Cribrocorona gallica (Stradner, 1963) Bramlette and Martini, 1964. 1, 3. Plane views in NL and XN. 2, 4. Lateral views in NL and XN. Sample 530A-50-1, 16-17 cm; Cretaceous/Tertiary boundary. 5. Oblique distal view; Sample 530A-50-2, 13-14 cm; SEM. 6. Oblique distal view; Sample 530A-50-2, 13-14 cm; SEM. 7. Distal view; Sample 530A-50-2, 22-23 cm; SEM. Cretaceous/Tertiary Boundary. 


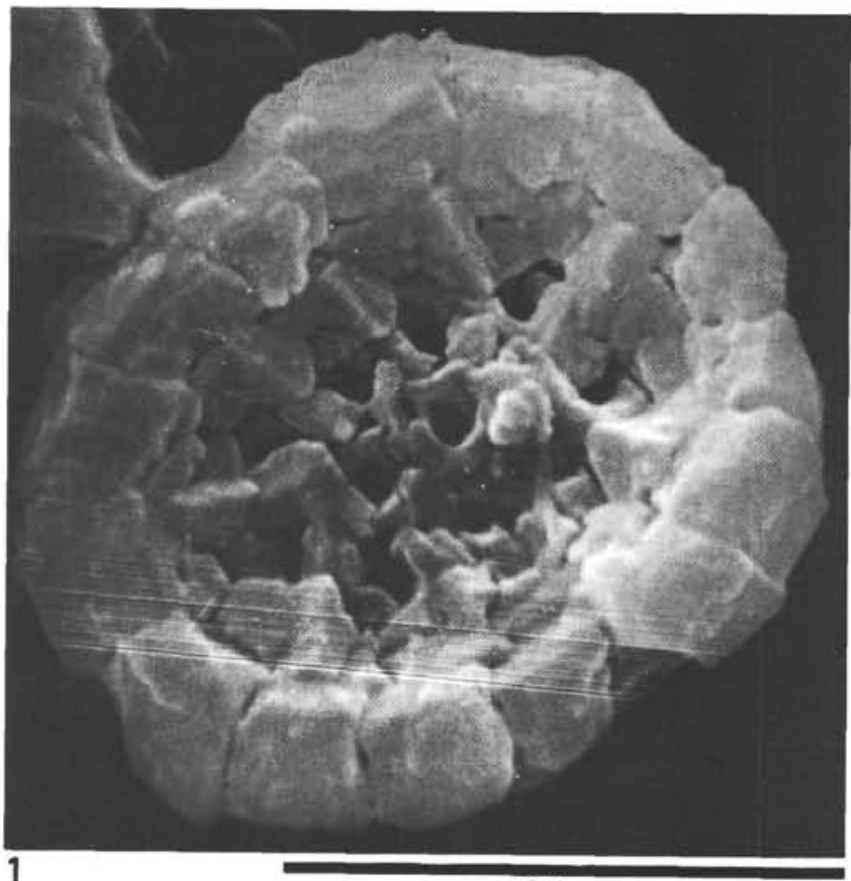

$$
1
$$



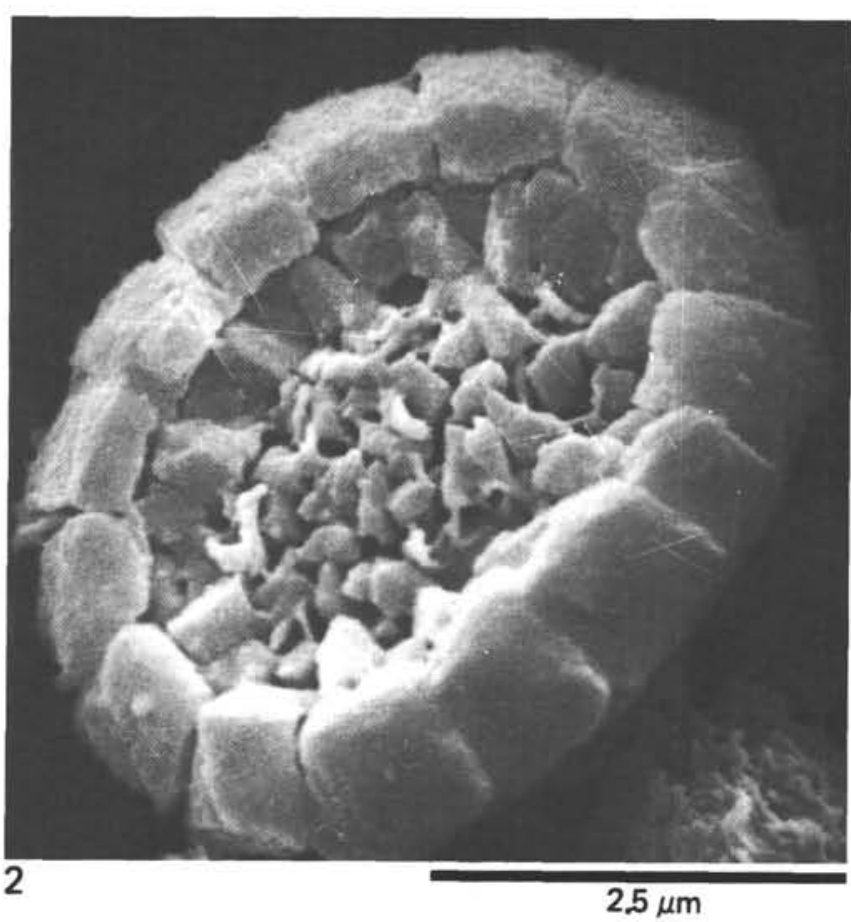

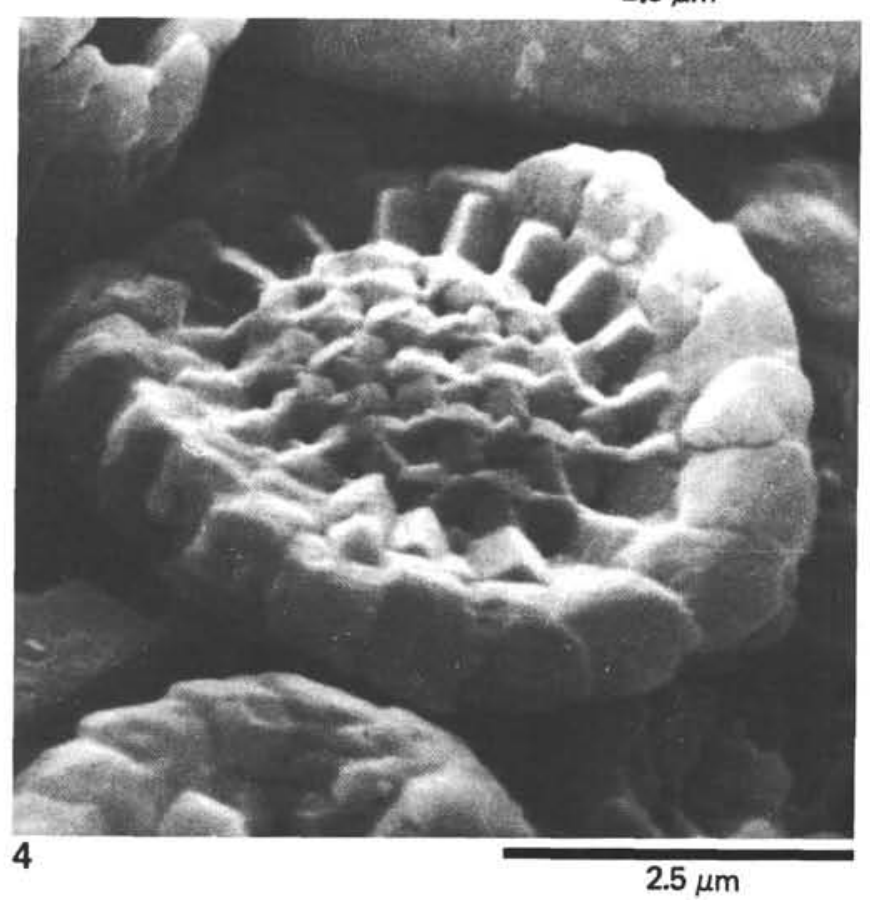

Plate 10. Cribrosphaerella ehrenbergi (Arkhangelsky, 1912) Deflandre, 1952. 1. Distal view; Sample 530A-78,CC. SEM. 2. Distal view; Sample 530A-77-2, 142-143 cm; SEM; early Campanian. 3. Proximal view; Sample 530A-77-2, 142-143 cm; SEM; early Campanian. 4. Oblique distal view; Sample 530A-94-2, 87-88 cm; SEM; early Coniacian. 


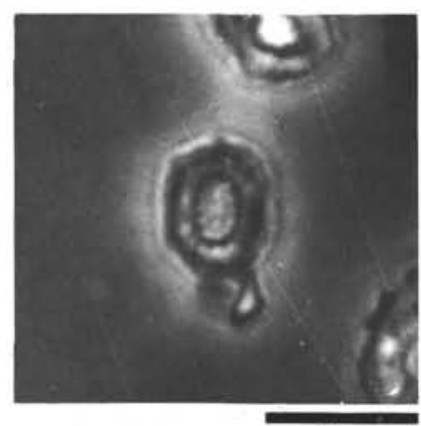

$5 \mu \mathrm{m}$

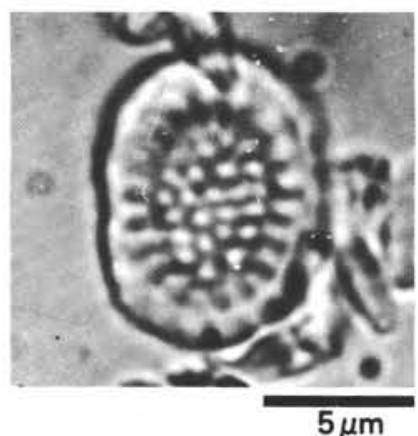

$5 \mu \mathrm{m}$

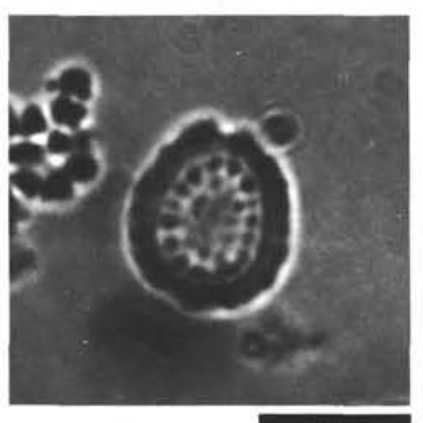

$5 \mu \mathrm{m}$

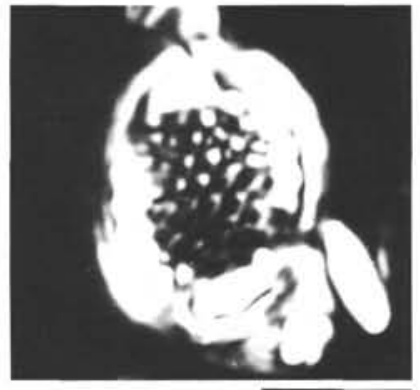

$5 \mu \mathrm{m}$

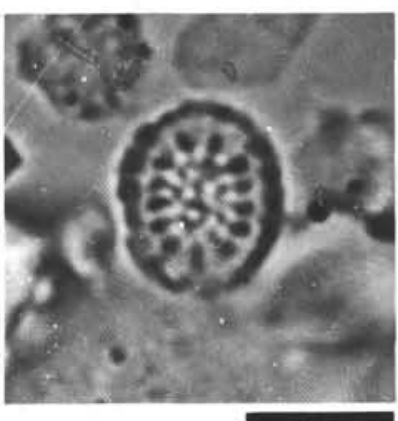

$5 \mu \mathrm{m}$

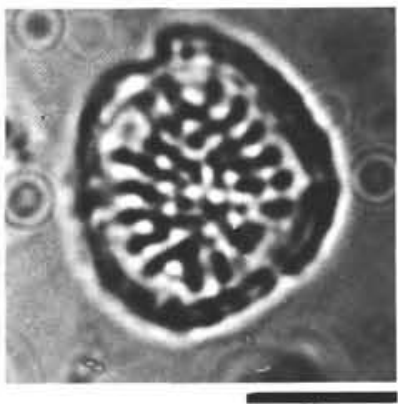

$5 \mu \mathrm{m}$

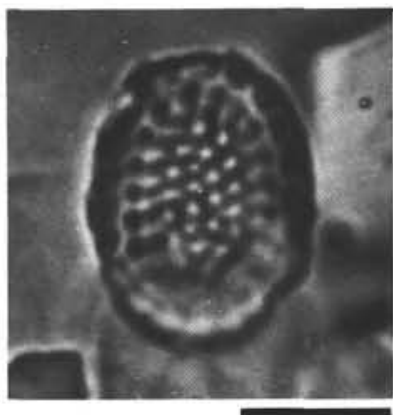

$5 \mu \mathrm{m}$

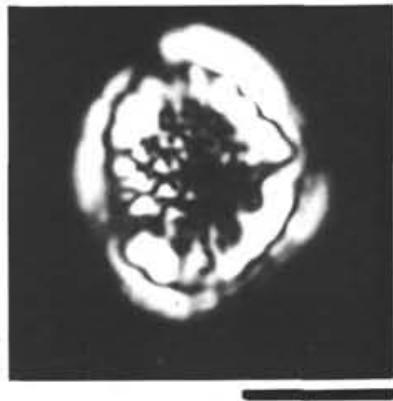

$5 \mu \mathrm{m}$



$2.5 \mu \mathrm{m}$

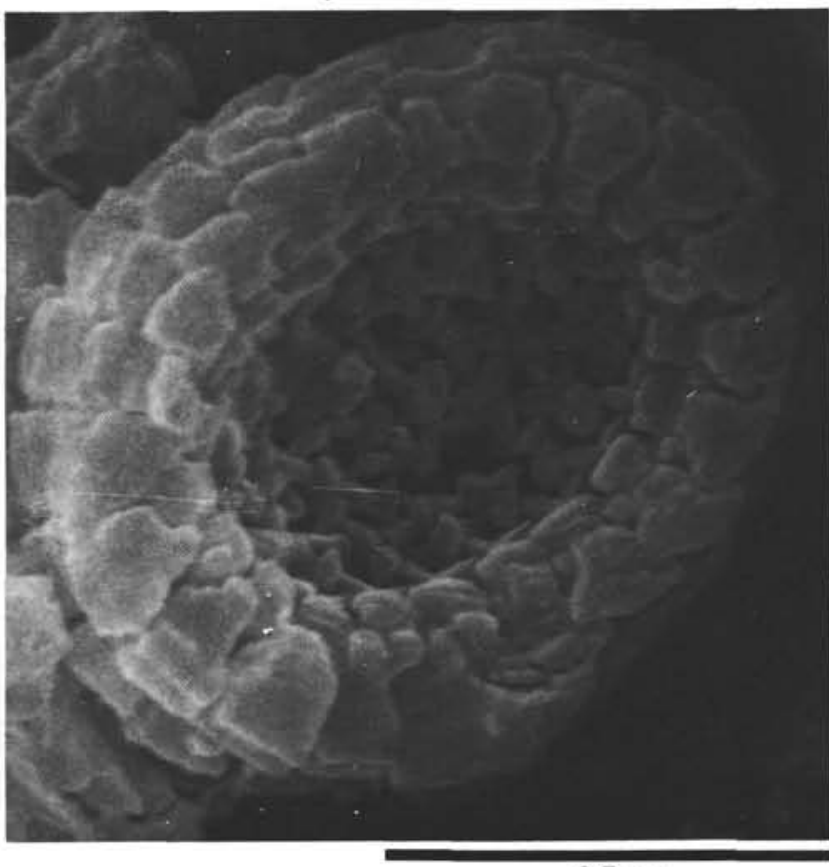

$2.5 \mu \mathrm{m}$

Plate 11. Cribrosphaerella ehrenbergi (Arkhangelsky, 1912) Deflandre, 1952. 1-4. Plane views in NL. (1) Sample 530A-94-2, 87-88 cm. (2) Sample 530A-79,CC. (3, 4) Sample 530A-50-2, 13-14 cm. 5, 6. Plane view in NL and XN; Sample 530A-50-1, 16-17 cm. 7, 8. Plane view in NL and XN of asymmetrical specimen; Sample 530A-50-1, 16-17 cm. 9. Distal view; Sample 530A-78,CC. SEM. 10. Proximal view; Sample 530A-77-2, 142-143 cm; SEM. Age: Early Coniacian (Fig. 1); early Campanian (Figs. 2, 9, 10); Cretaceous/Tertiary boundary (Figs. 3-8). 

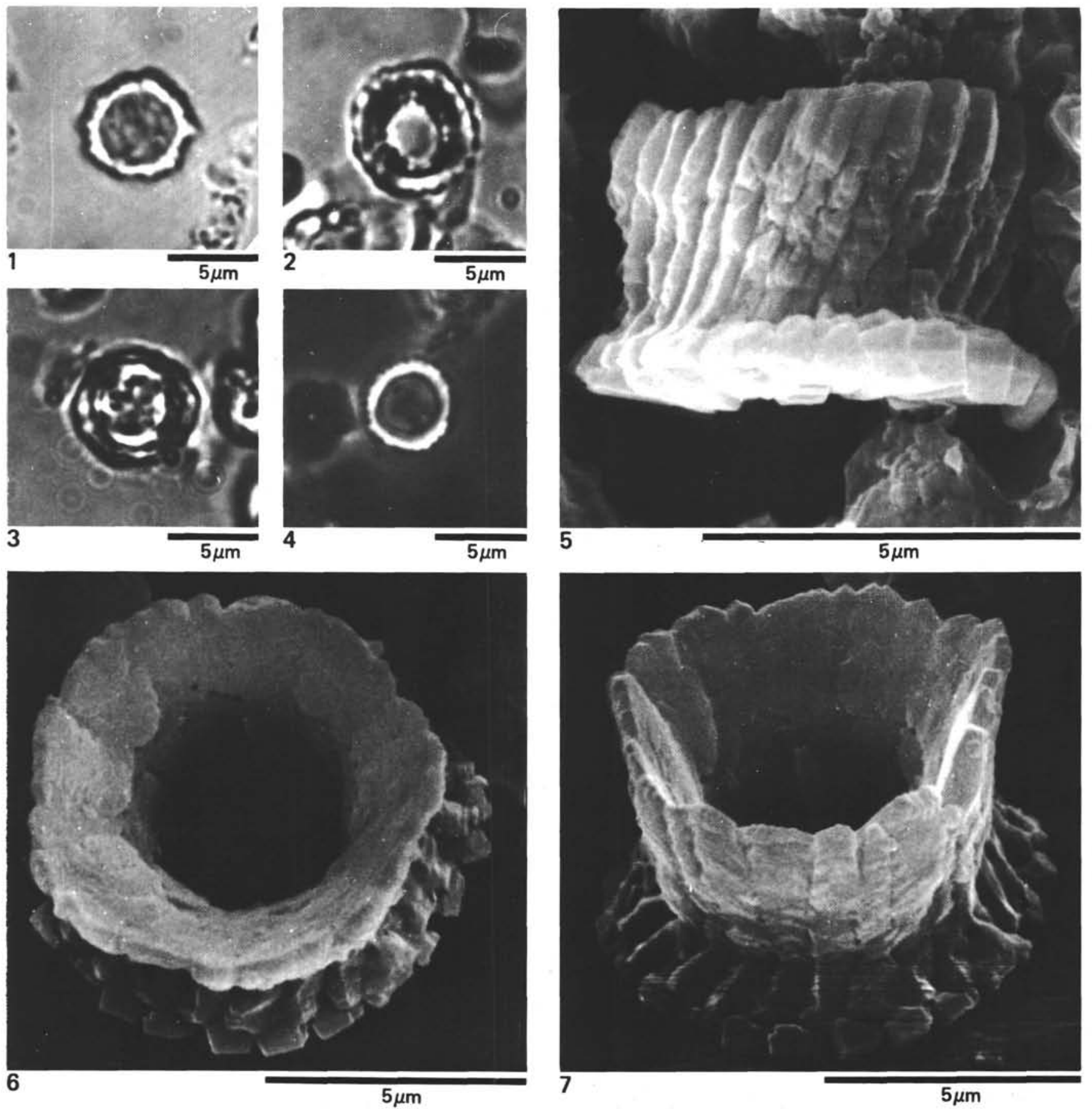

Plate 12. Cylindralithus serratus Bramlette and Martini, 1964. 1. Axial view; Sample 530A-79,CC; NL; high focus. 2. Axial view; Sample 530A-79,CC; NL; focused on broad rim. 3. Axial view; Sample 530A-77-7, 110-111 cm; NL. 4. Axial view; Sample 530A-79,CC; PHC. 5. Lateral view; Sample 530A-76-5, 110-111 cm; SEM. 6. Axial view; Sample 530A-79,CC; SEM. 7. Oblique view; Sample 530A-79,CC; SEM. Early Campanian. 

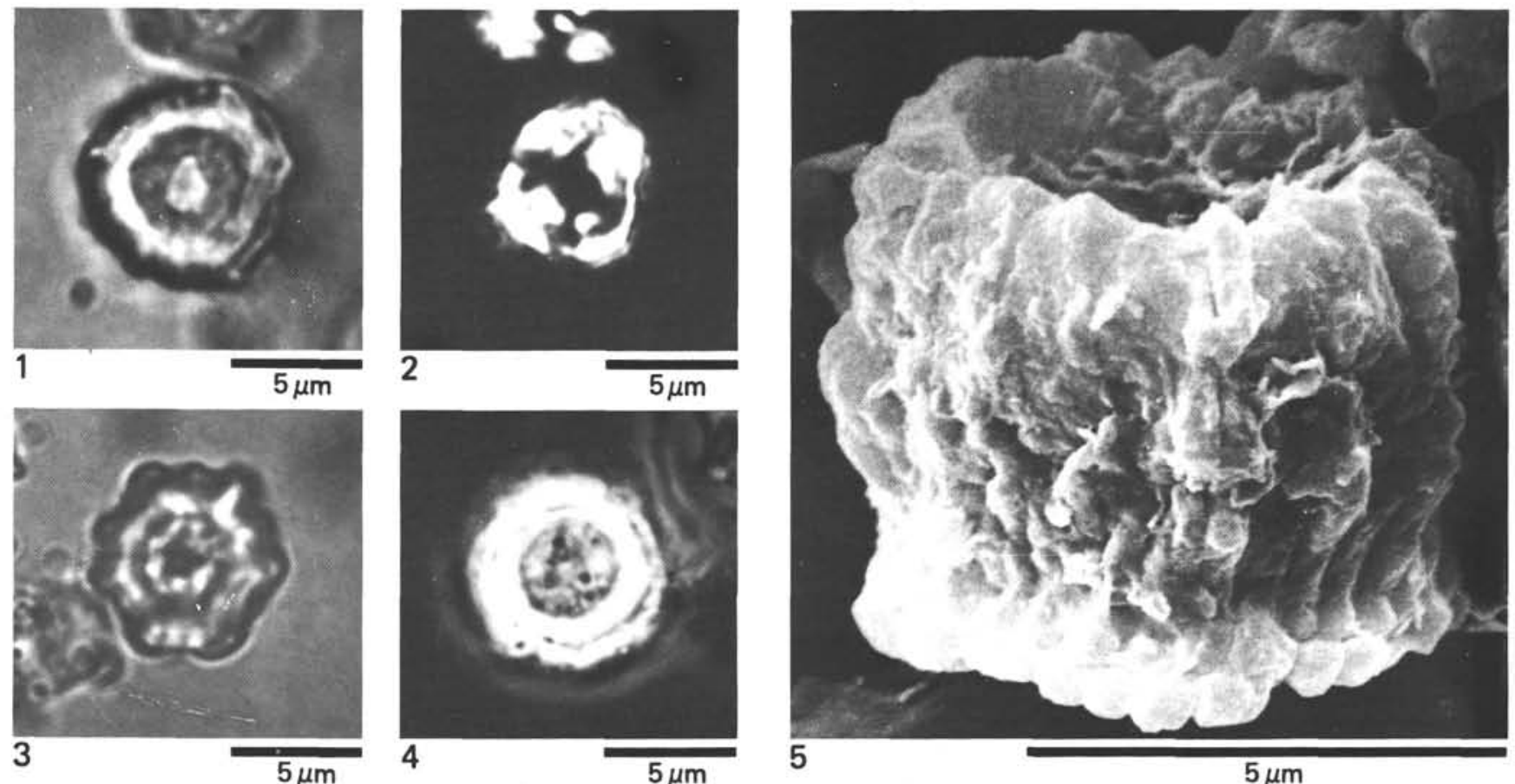

3
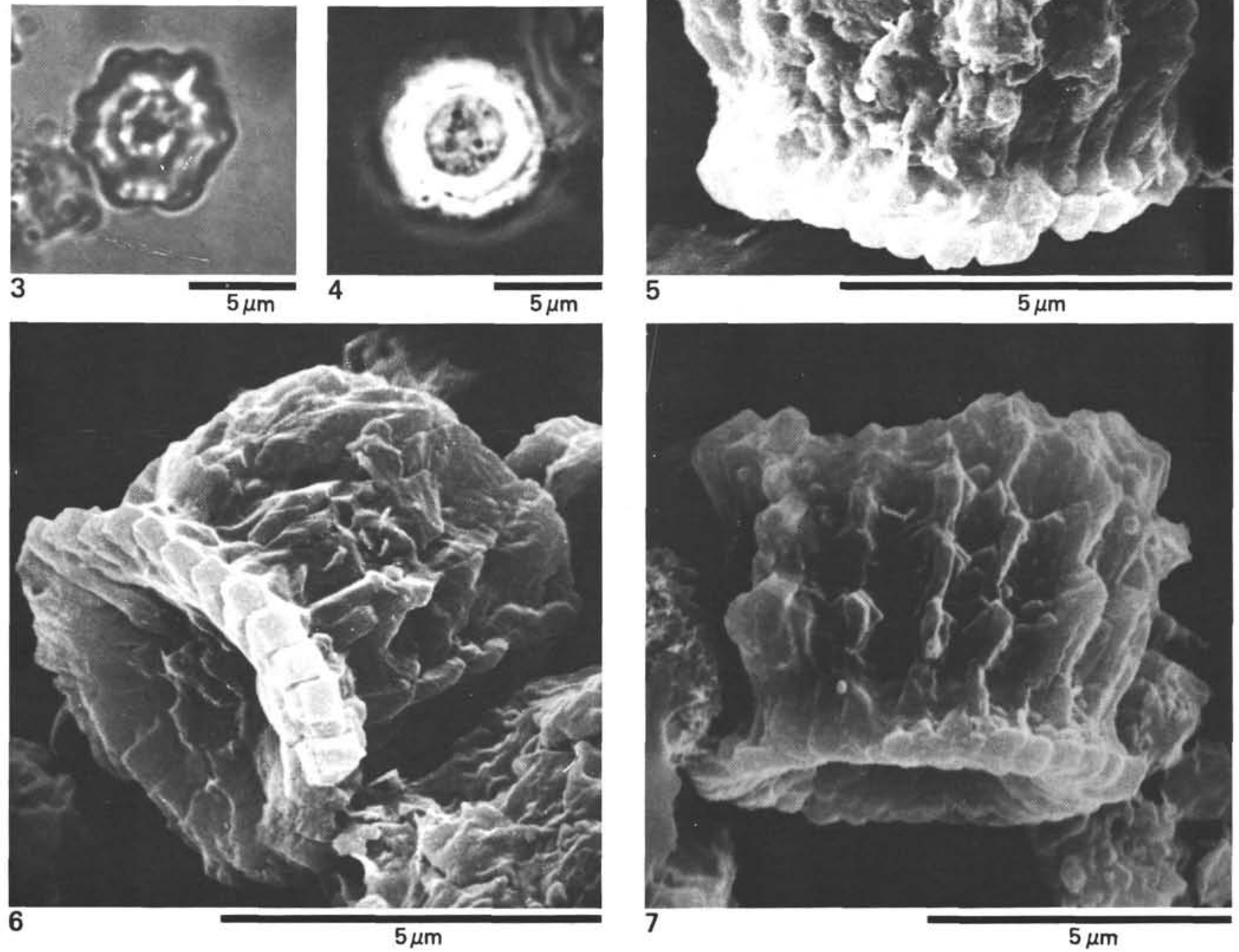

$5 \mu \mathrm{m}$

Plate 13. Cylindralithus sculptus Bukry, 1969. 1-3. Axial views; Sample 530A-77-2, 142-143 cm; NL, XN, NL. 4. Axial view; Sample 530A79,CC; negative PHC. 5. Lateral view; Sample 530A-77-2, 142-143 cm; SEM. 6. Oblique lateral view; Sample 530A-79,CC; SEM. 7. Lateral view; Sample 530A-76-5, 110-111 cm; SEM. Early Campanian. 


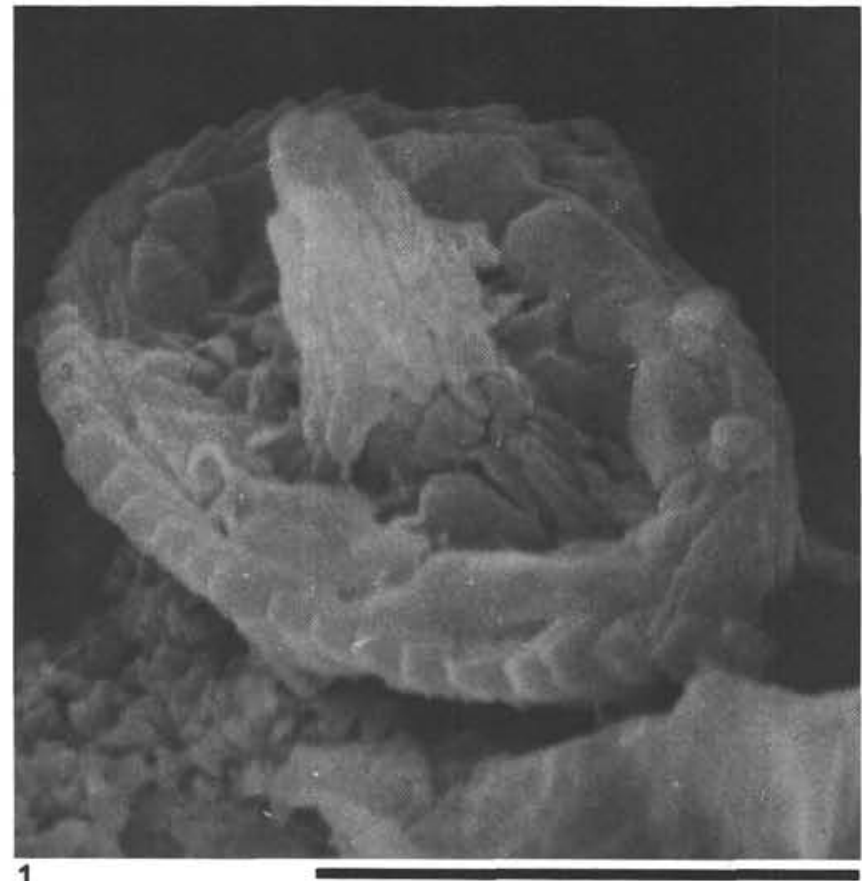

1

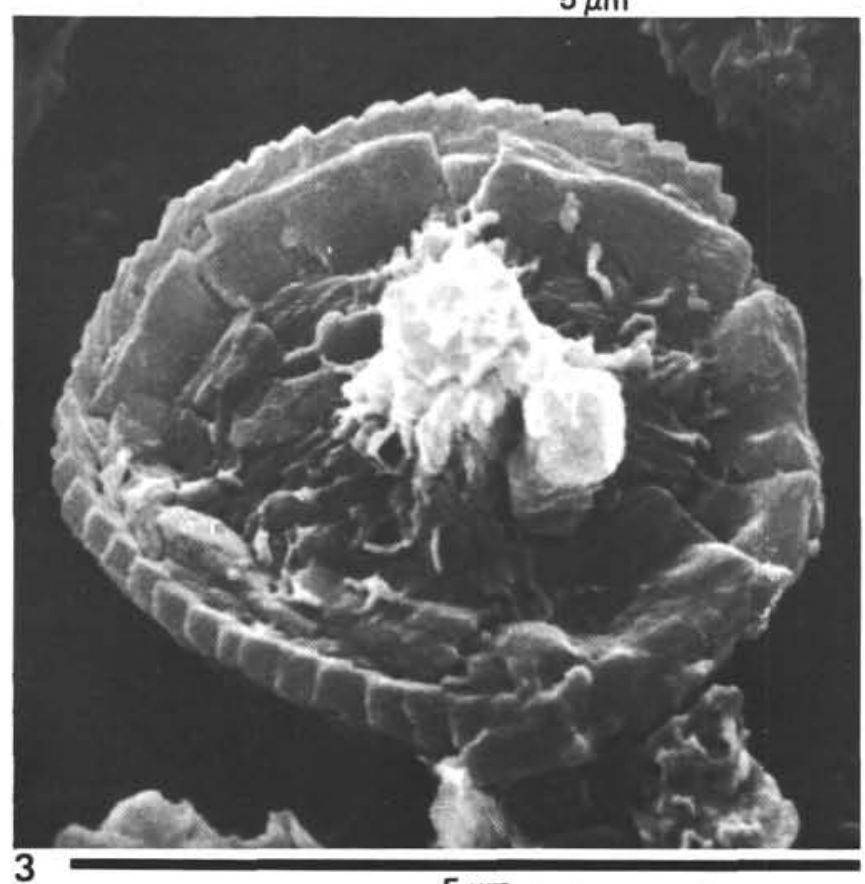

$5 \mu \mathrm{m}$


Plate 14. Eiffellithus eximius (Stover, 1966) Perch-Nielsen, 1968. 1. Oblique distal view; Sample 530A-77-2, 142-143 cm; SEM; early Campanian. 2. Distal view of reworked, corroded specimen; Sample 530A-50-2, 22-23 cm; SEM; Cretaceous/Tertiary boundary. 3. Oblique distal view; Sample 530A-77-2, 142-143 cm; SEM. 4. Distal view; Sample 530A-76-5, 110-111 cm; SEM. Early Campanian. 

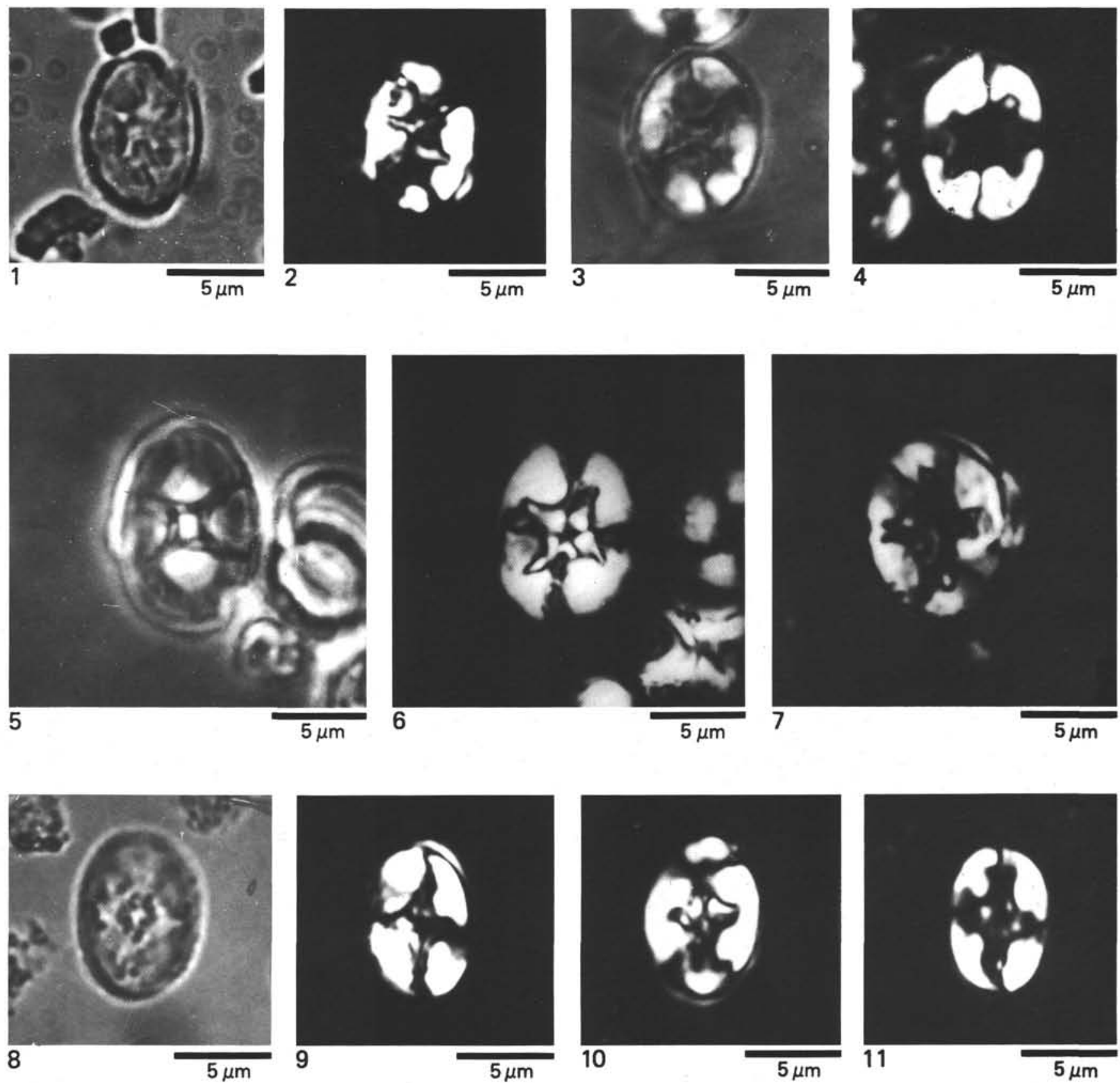

Plate 15. 1-6. Eiffellithus turriseiffeli (Deflandre and Fert, 1954) Reinhardt, 1965; plane views. 1, 2. NL and XN; Sample 530A-105-4, 8-9 cm; late Albian. 3. Sample 530A-94-2, 87-88 cm; NL, XN; early Coniacian. 4. Sample 530A-89-1, 80-81 cm; XN; Coniacian. 5. Sample 530A94-2, 87-88 cm; PHC; early Coniacian. 6. Sample 530A-77-2, 142-143 cm; XN; early Campanian. 7-11. Eiffellithus eximius (Stover, 1966) Perch-Nielsen, 1968; plane views. 7, 11. Sample 530A-78-3, 30-31 cm; XN; early Campanian. 8, 9. Sample 530A-79,CC; NL, XN; early Campanian. 10. Sample 530A-89-1, 80-91 cm; XN; Coniacian. 

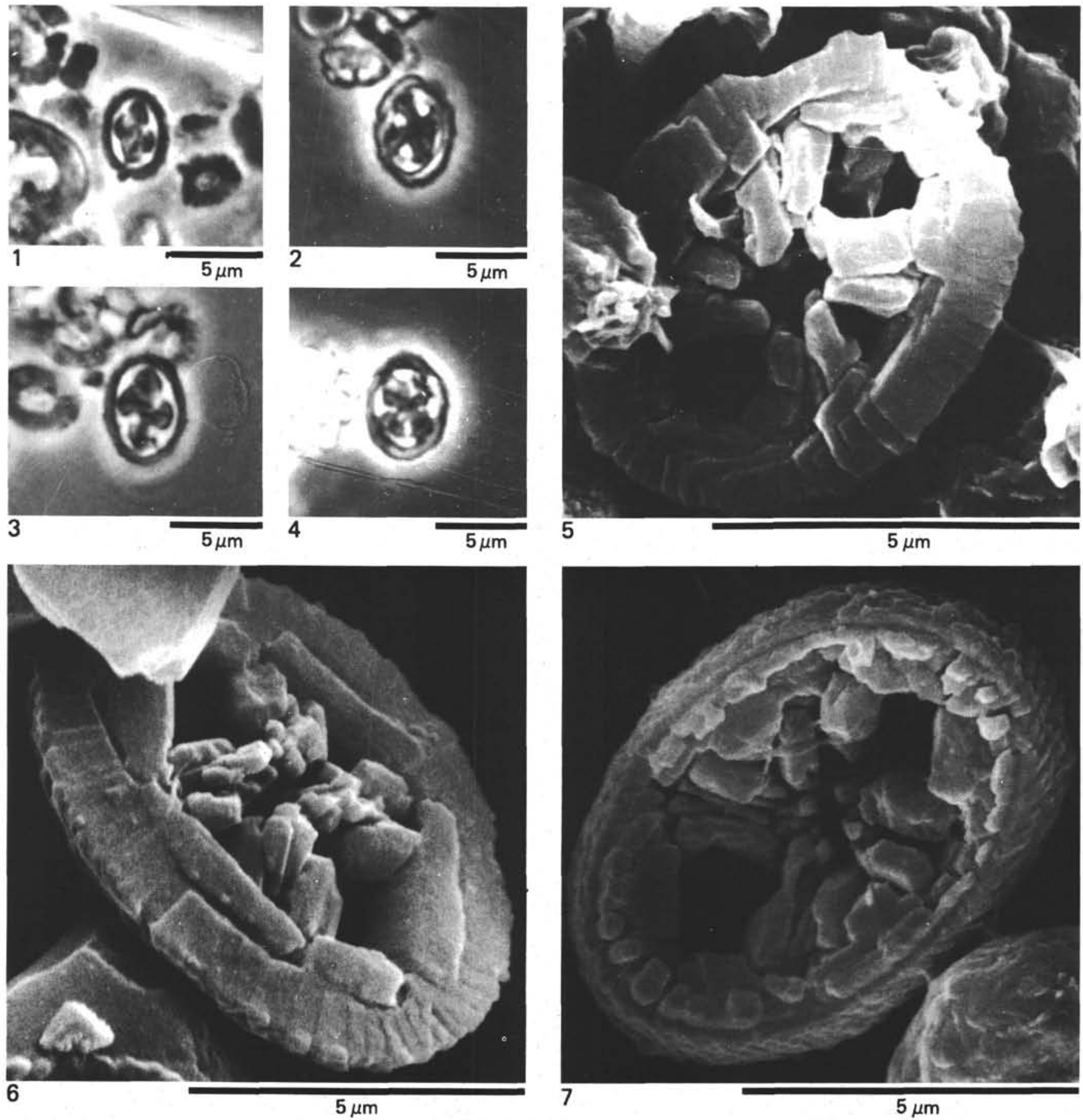

Plate 16. Helicolithus trabeculatus (Gorka, 1957) Verbeek, 1977. 1, 3. Plane views; Sample 530A-100-2, 98-99 cm; PHC; late Cenomanian to early Turonian. 2, 4. Plane views; Sample 530A-94-2, 87-89 cm; PHC; early Coniacian. 5. Distal view; Sample 530A-76-5, 110-111 cm; SEM; early Campanian. 6. Oblique distal view; Sample 530A-50-2, 13-14 cm; SEM; Cretaceous/Tertiary boundary. 7. Proximal view; Sample 530A-50-2, 22-23 cm; SEM; Cretaceous/Tertiary boundary. 



Plate 17. Gartnerago obliquum (Stradner, 1963) Locker, 1972; SEM.1, 4. Oblique distal views; Sample 530A-76-5, 110-111 cm. 2. Oblique distal view; Sample 530A-78,CC. 3. Oblique proximal view; Sample 530A-76-5, 110-111 cm. Early Campanian. 

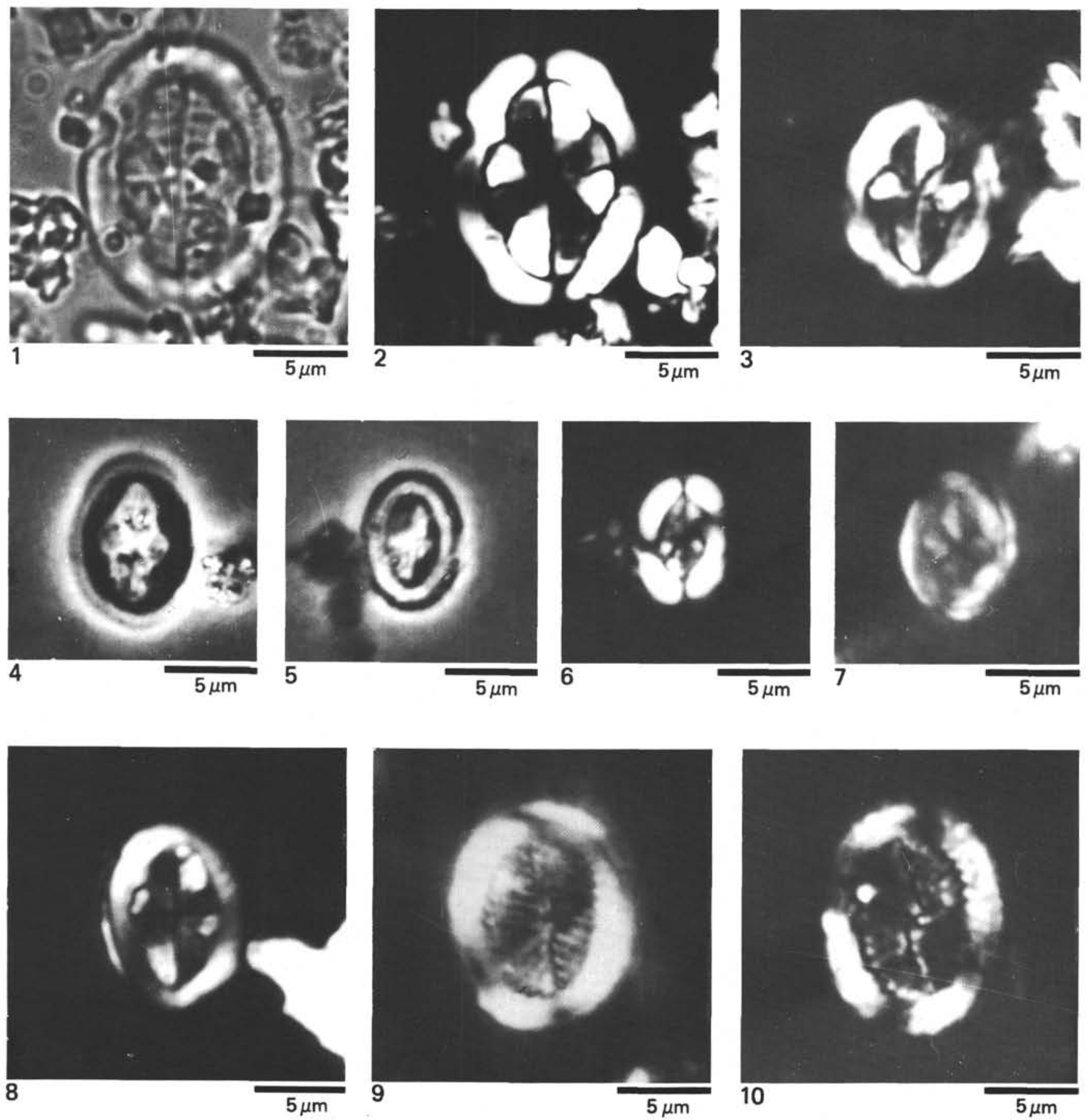

Plate 18. 1, 2. Gartnerago segmentatum (Stover, 1966) Thierstein, 1974; plane view in NL and XN; Sample 530A-51-1, 16-17 cm; Cretaceous/Tertiary boundary. 3, 4, 7, 8. Gartnerago obliquum (Stradner, 1963) Locker, 1972. Plane views in PHC (Figs. 4, 7) and XN (Figs. 3, 8); Sample 530A-77-2, 142-143 cm (Figs. 3, 4, 8); early Campanian, Sample 530A-94-2, 87-89 cm (Fig. 7); early Coniacian. 5, 6. Broinsonia enormis (Shumenko, 1968) Manivit, 1971. Plane views of specimen in PHC and XN; Sample 530A-79,CC; early Campanian. 9, 10. Gartnerago striatum (Stradner, 1963) Forchheimer, 1972. Plane views in XN; Sample 530A-100-2, 98-99 cm; Late Cenomanian to early Turonian. 

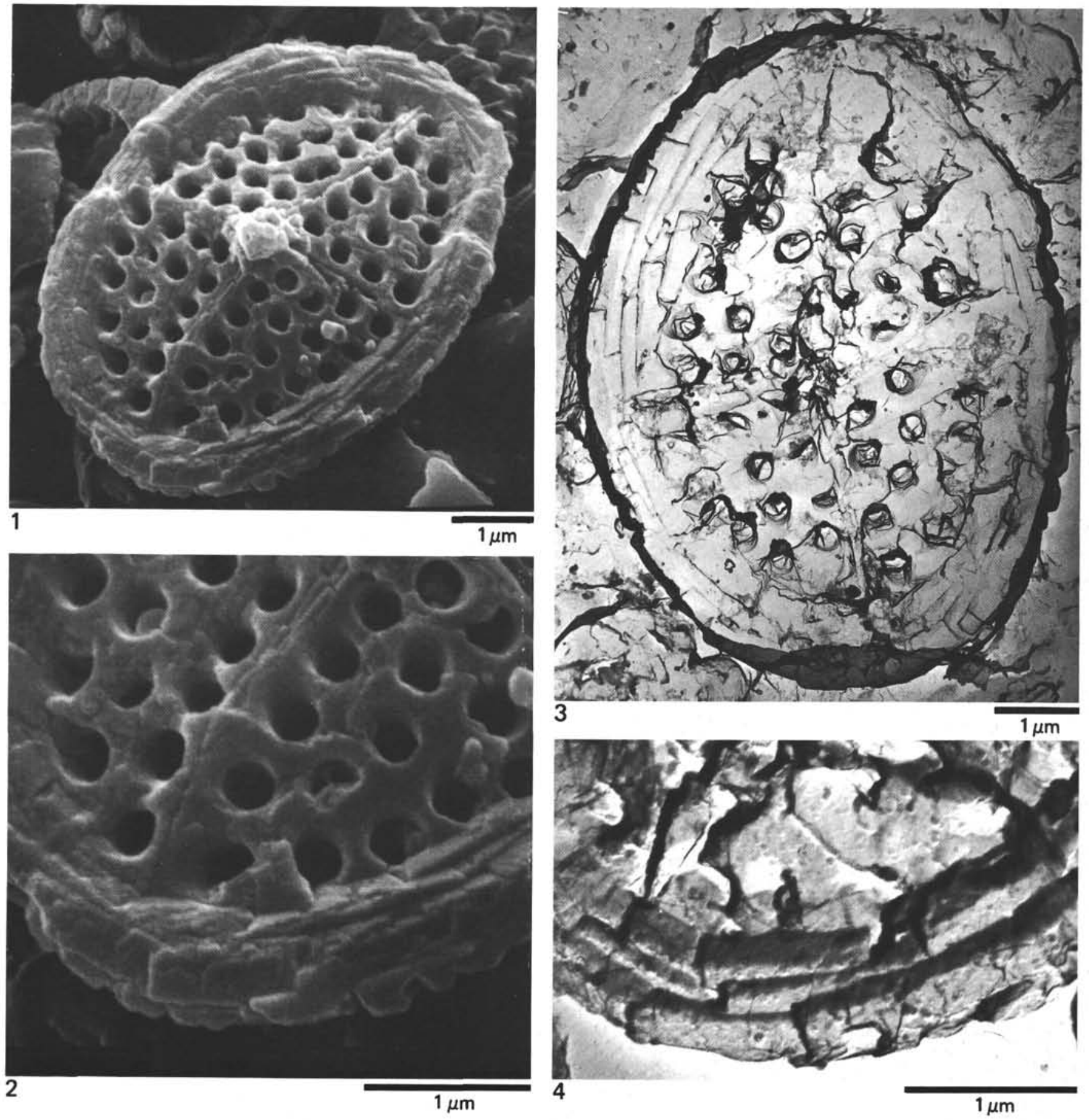

Plate 19. Gartnerago striatum (Stradner, 1963) Forchheimer, 1972; distal views. 1, 2. SEM; lectotypes. 3, 4. TEM; lectotypes. Type-sample from the DELFT 2 deepwell, Netherlands. Albian. 

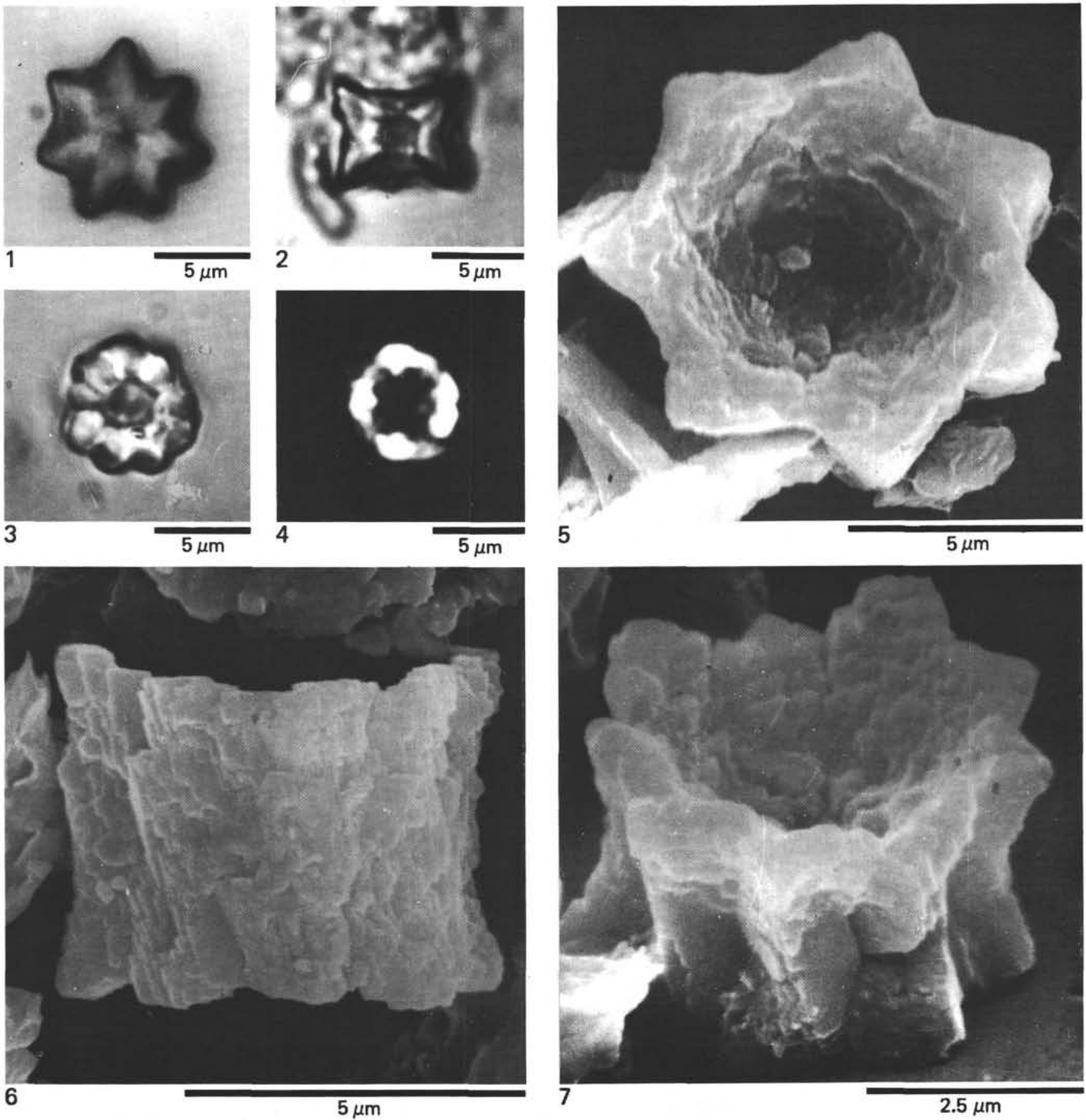

Plate 20. 1, 2, 5. Lithastrinus moratus Stover, 1966; Sample 530A-95-1, 107-108 cm. (1) Axial view; NL. (2) Lateral view; NL. (5) Axial view; SEM. Late Turonian. 3, 4, 6, 7. Lithastrinus floralis Stradner, 1962. (3) Axial views in NL; Sample 530A-77-2, 110-111 cm; early Campanian. (4) Axial view in XN; Sample 530A-95-1, 107-108 cm; late Turonian. $(6,7)$ Lateral view and oblique axial view; SEM; Sample 530A-95-1, 107$108 \mathrm{~cm}$; late Turonian. 

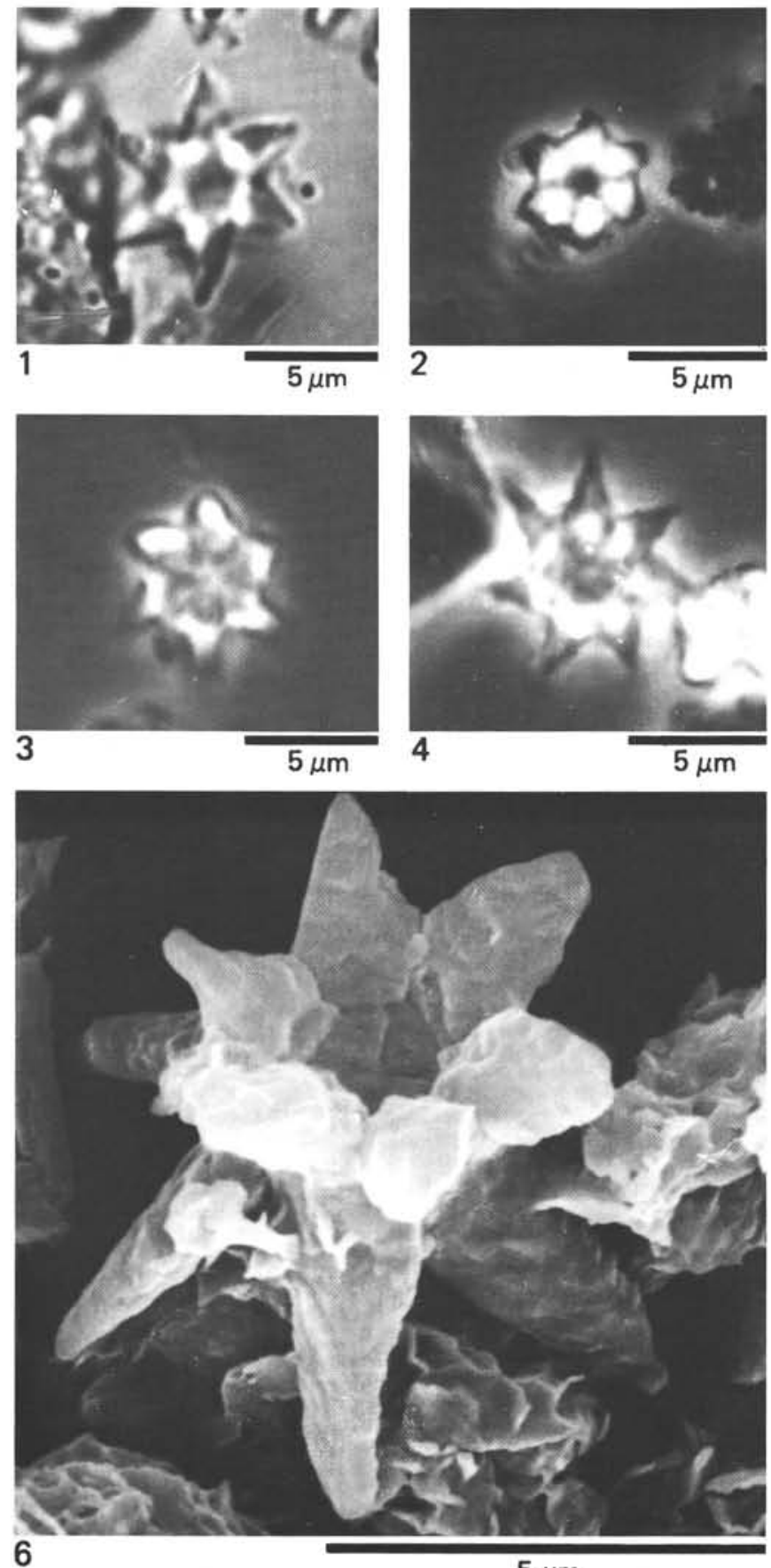

$5 \mu \mathrm{m}$
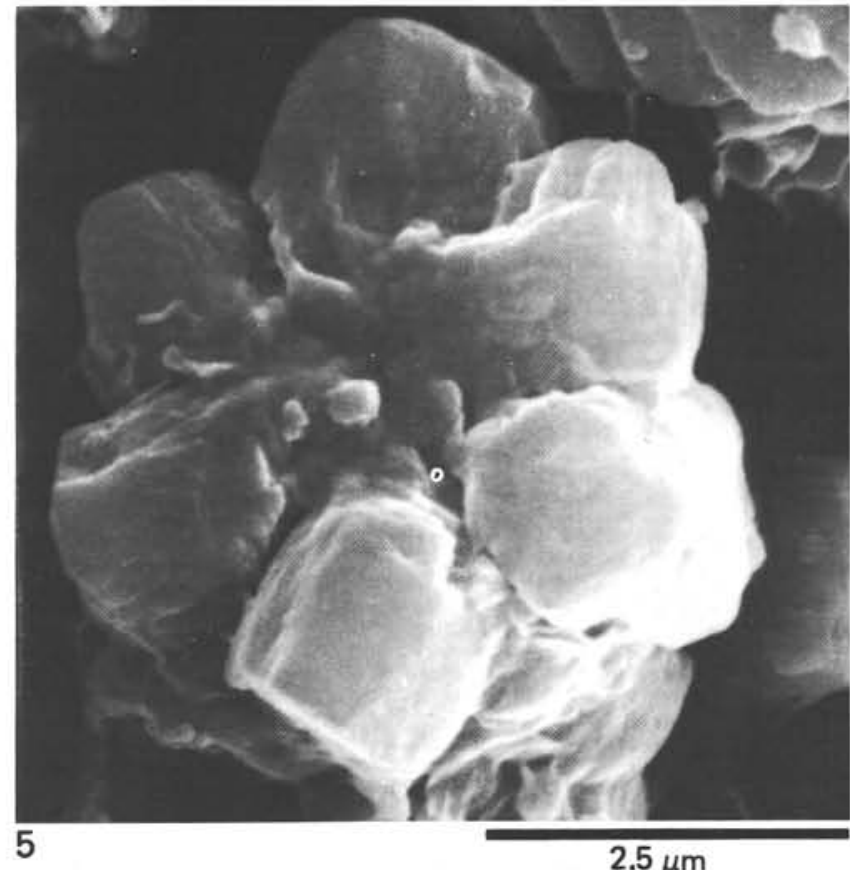

$2.5 \mu \mathrm{m}$

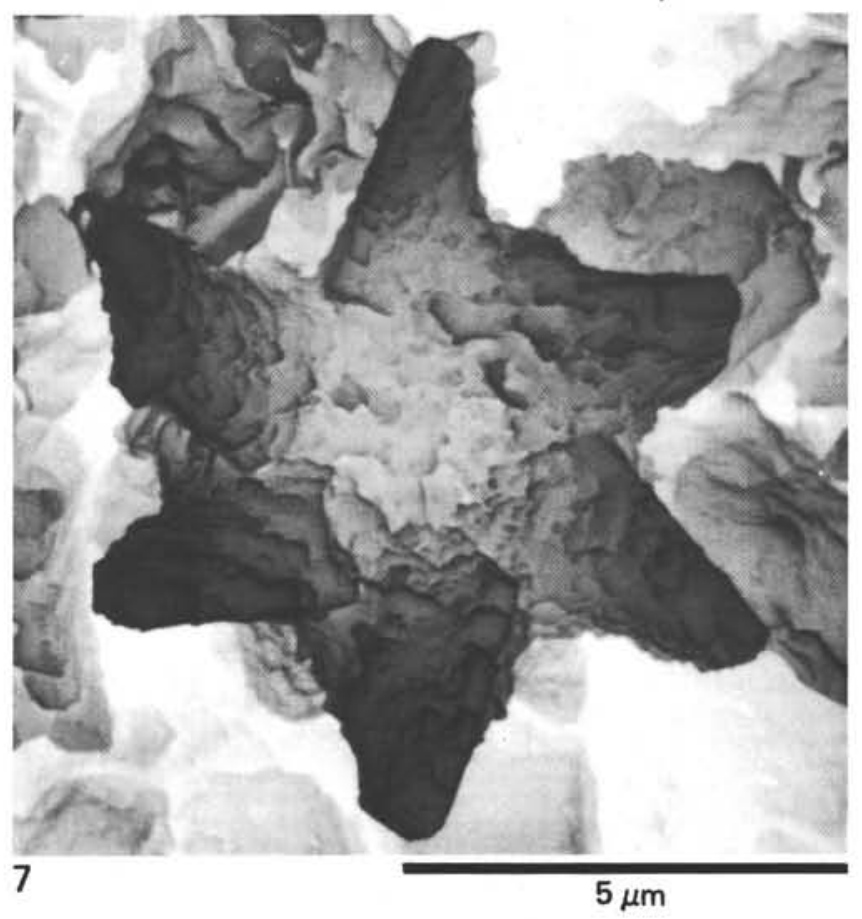

Plate 21. 1-3, 5-7. Lithastrinus grilli Stradner, 1962. (1-3) Axial views; Sample 530A-79,CC; NL (Fig. 1); PHC (Figs. 2 and 3). (5) Heavily recrystallized specimen in axial view; Sample 530A-76-5, 110-111 cm; SEM. (6) Oblique view; Sample 530A-76-5, 110-111 cm; SEM. (7) Axial view, Sample 530A-76-5, 110-111 cm;SEM; reversed print; early Campanian. 4. Lithastrinus septenarius Forchheimer, 1972. Axial view; Sample 530A-89-1, 80-81 cm; PHC; Coniacian. 


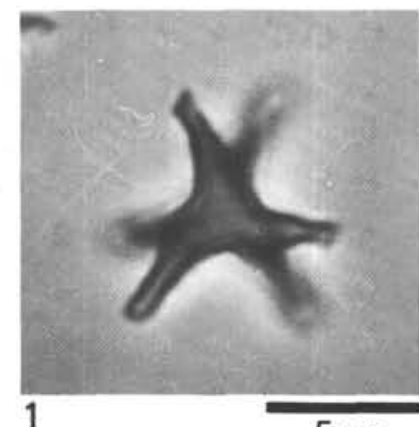

1
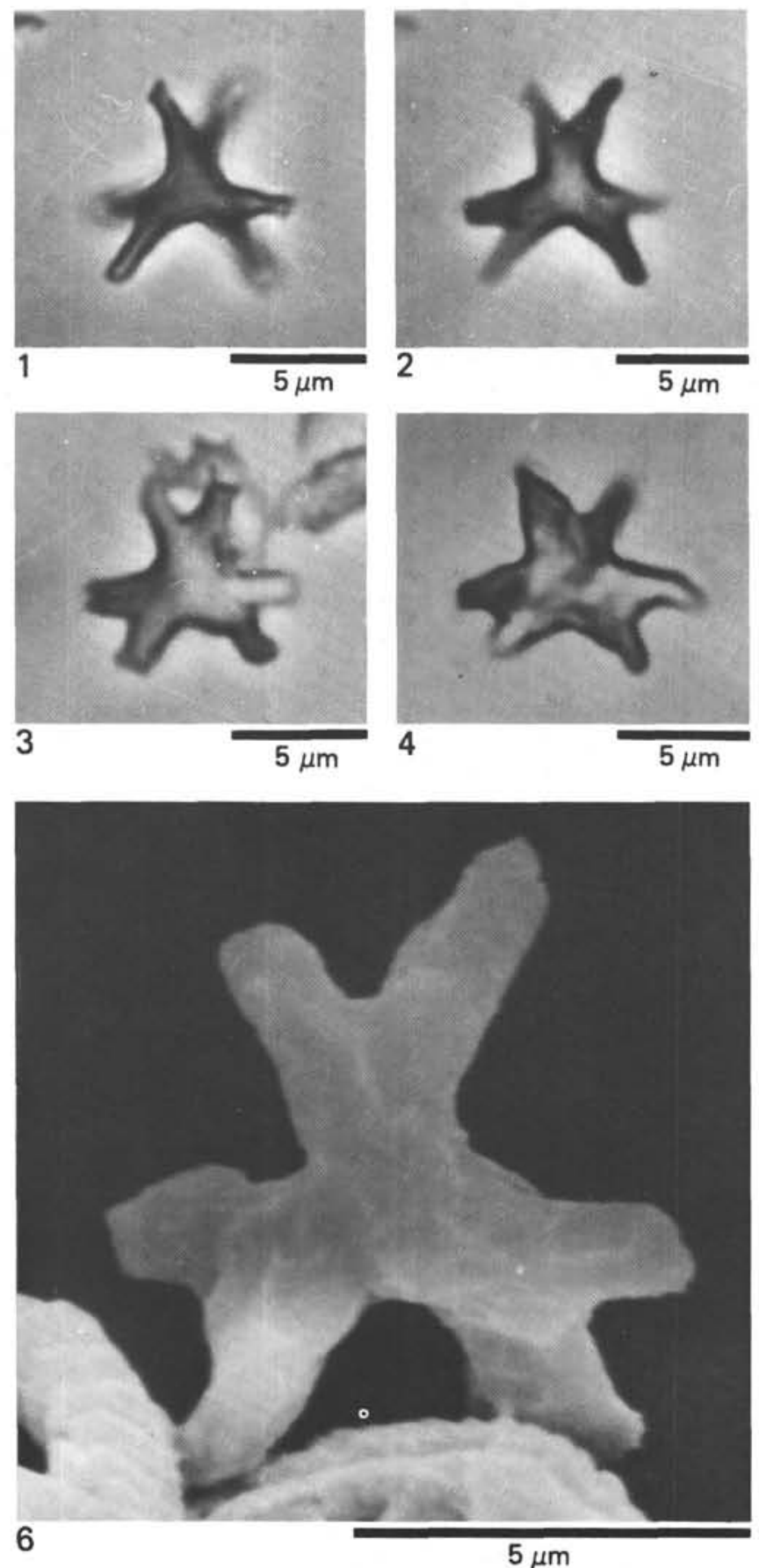

$5 \mu \mathrm{m}$

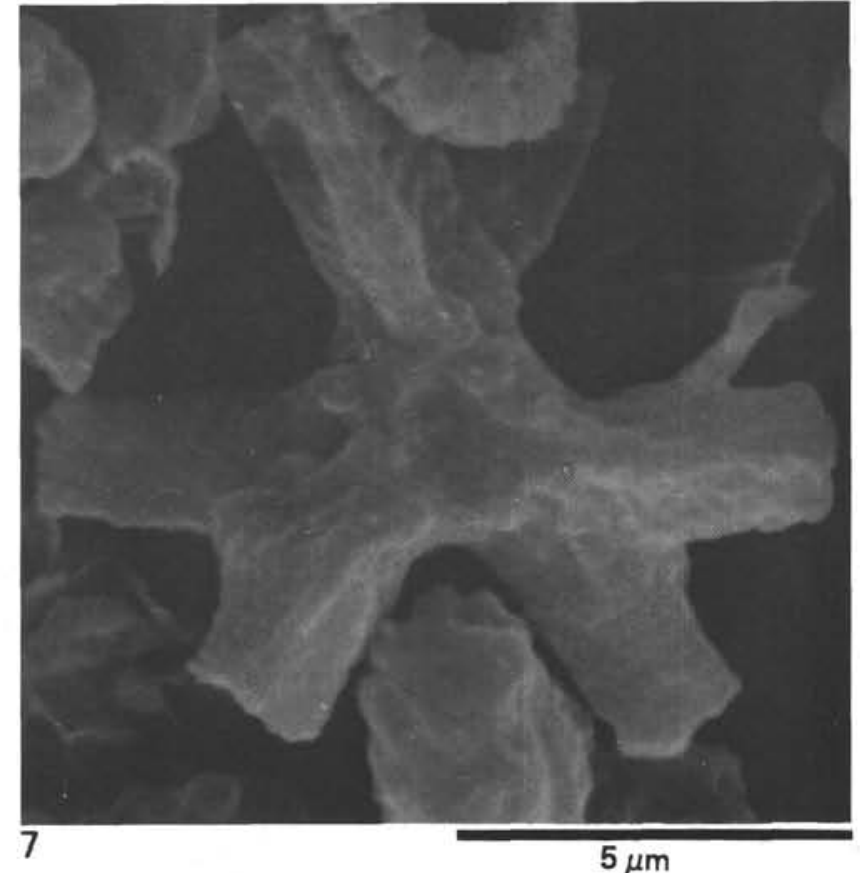

Plate 22. 1-6. Liliasterites angularis Śvabénická and Stradner nov. spec.; plane view. (1-4) Gold-coated specimens in NL; high focus (Fig. 1); low focus of same hypotype (Fig. 2). (5) Slightly edged specimen; SEM. (6) SEM. Sample 530A-95-1, 107-108 cm; late Turonian. 7. Liliasterites atlanticus Stradner and Steinmetz nov. gen. nov, spec.; plane view of Paratype specimen; Sample 530A-95-1, 107-108 cm; late Turonian. 


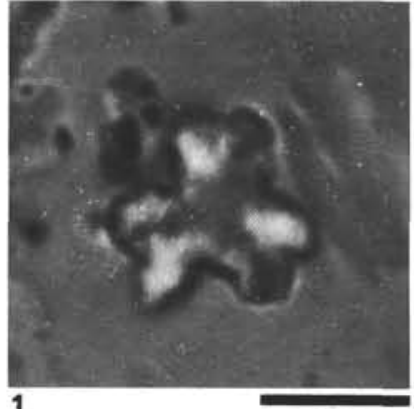

1



$5 \mu \mathrm{m}$



$5 \mu \mathrm{m}$



$5 \mu \mathrm{m}$
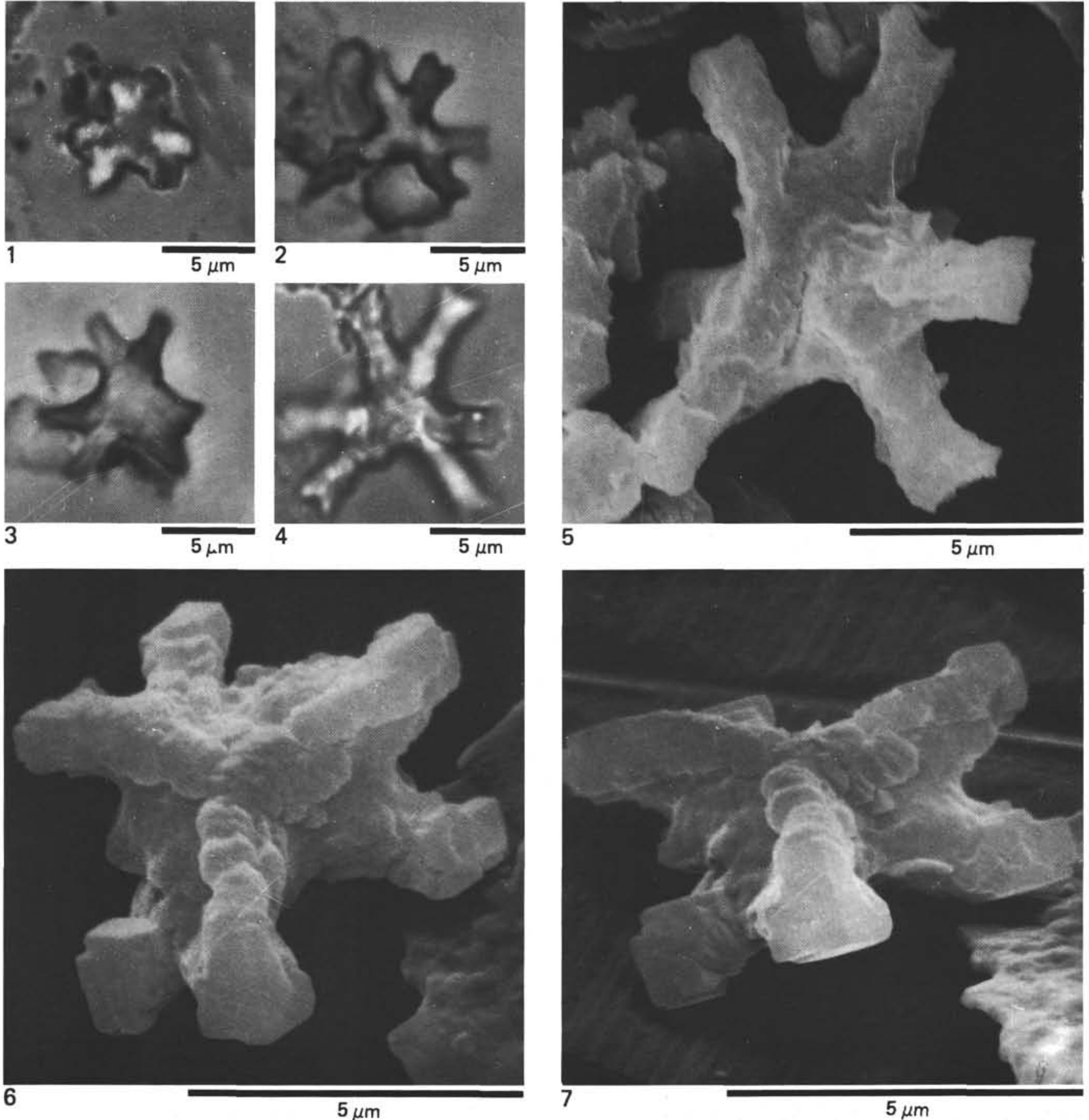

Plate 23. 1, 2, 4-7. Liliasterites atlanticus Stradner and Steinmetz nov. gen. nov. spec. (1) Plane view of corroded specimen; LM. (2, 4) Plane views of paratypes with notched rays; NL. (5) Plane view of holotype specimen with notched rays and distinct suture-line; SEM; (6 and 7$)$ Recrystallized specimen in plane and oblique view; SEM. 3. Liliasterites angularis Svabénická and Stradner nov. spec.; plane view. NL. Sample 530A-95-1, 107-108 $\mathrm{cm}$, late Turonian. 


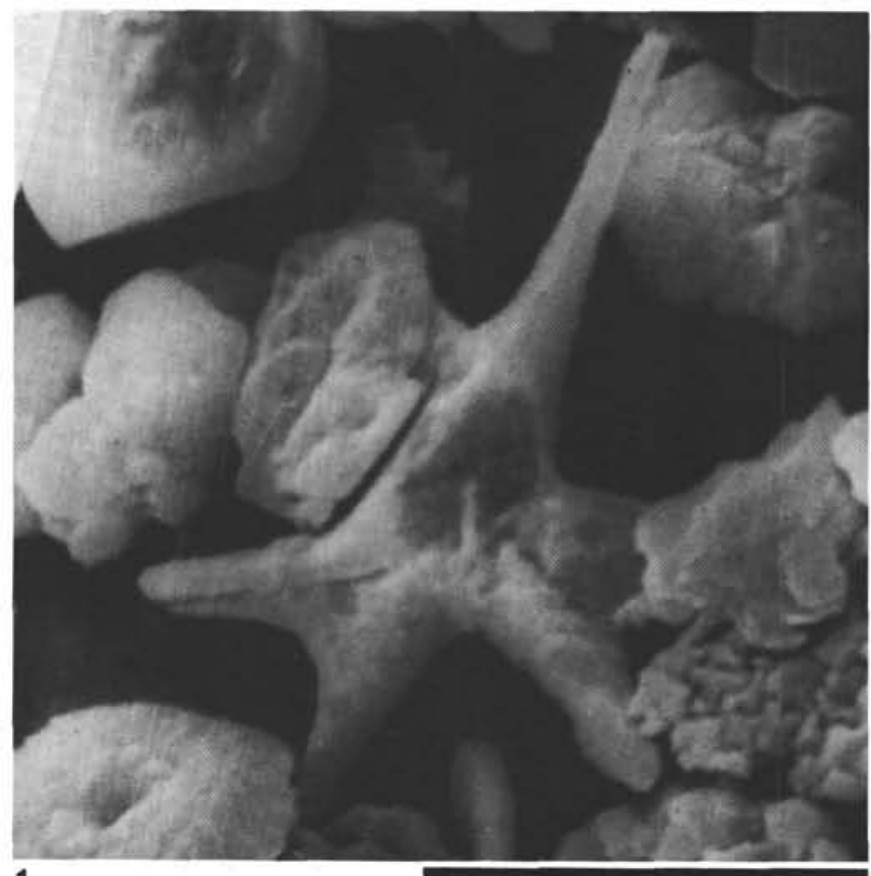

1

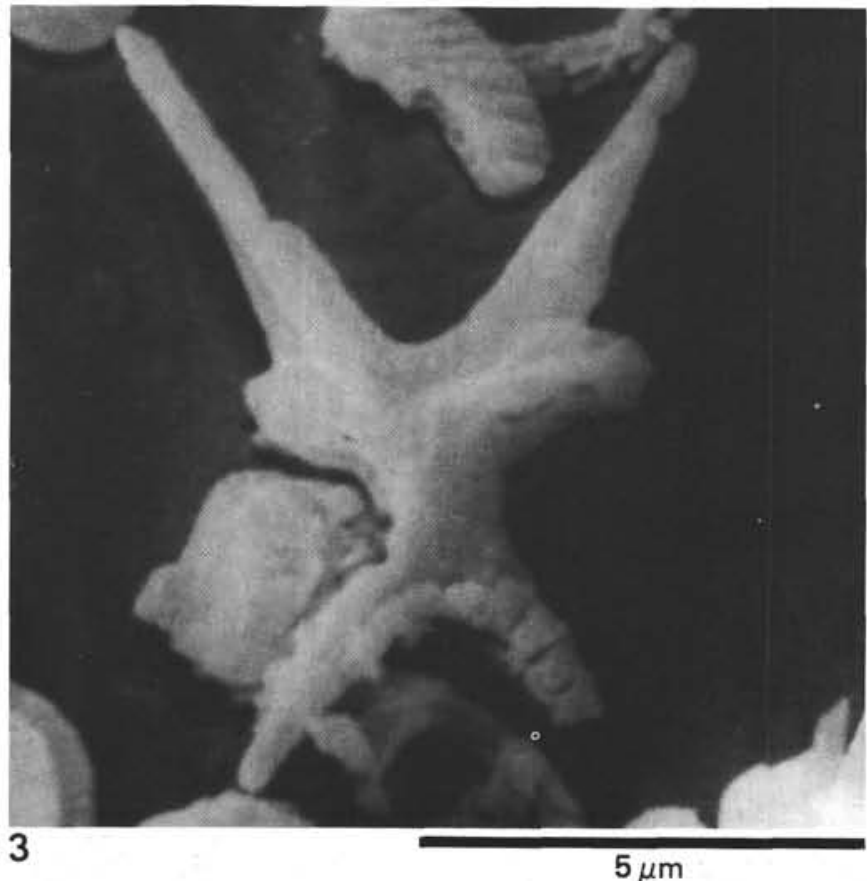

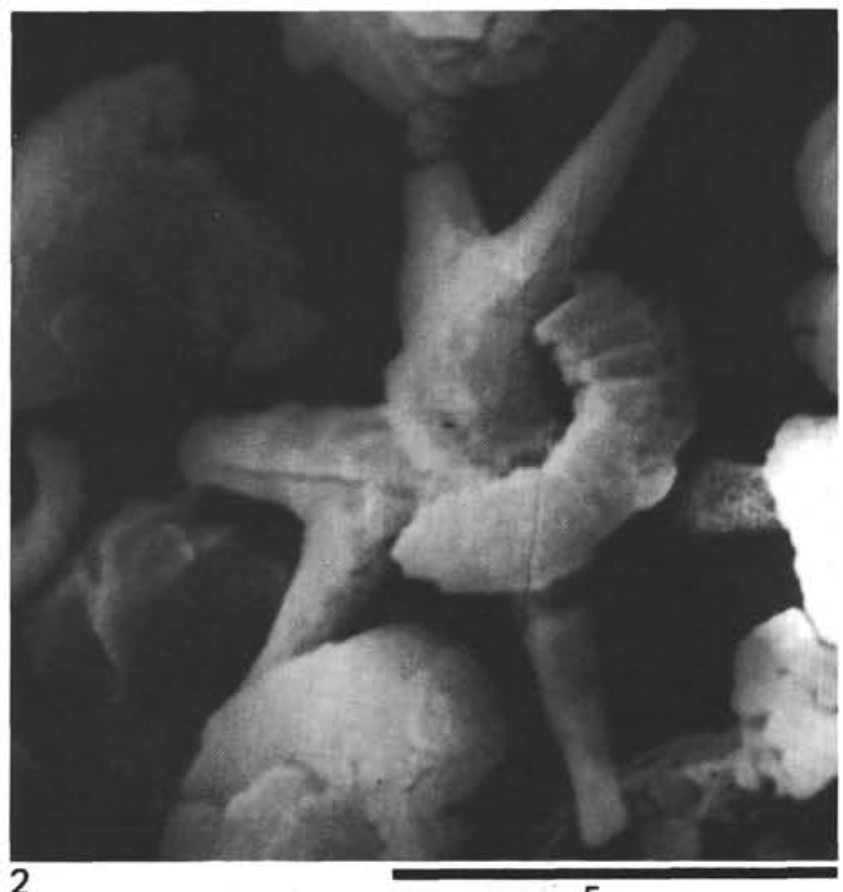

$5 \mu \mathrm{m}$

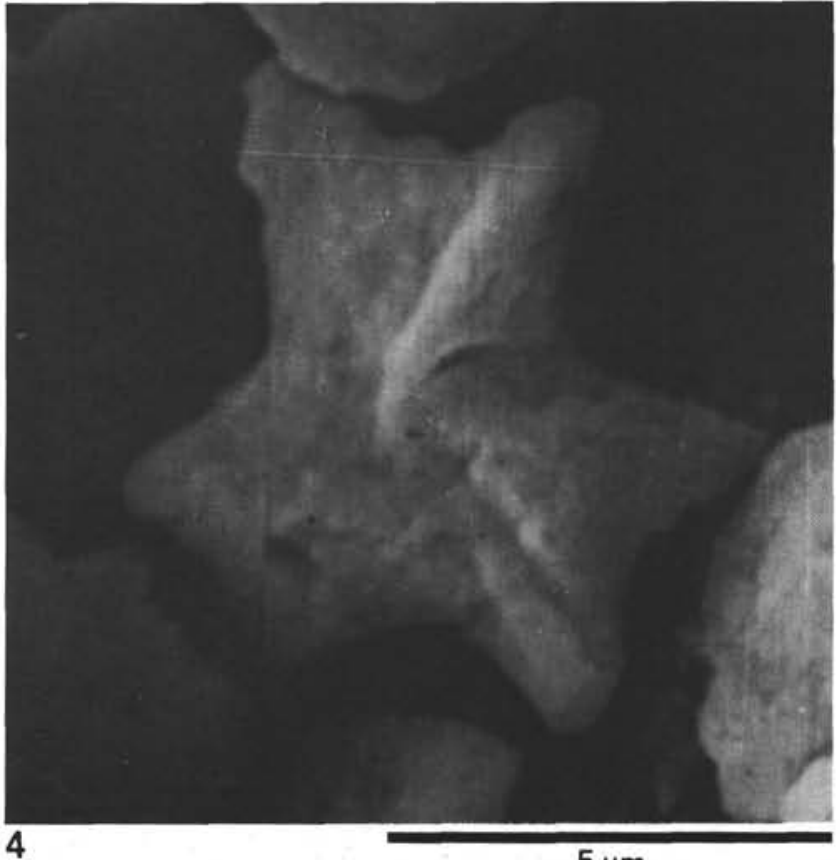

$5 \mu \mathrm{m}$

Plate 24. Liliasterites angularis Švabénická and Stradner nov. spec. 1. Plane view of holotype specimen; SEM. 2, 3. Plane view of paratype specimens; SEM. 4. Central part of smaller (?corroded) paratype specimen. All four type specimens with distinct suture lines; type sample from an outcrop in Kystra, Bohemia, CSSR; late Turonian. SEM micrographs by Ing. R. Rybka, Geochemical Laboratory of the Geological Survey of Prague, CSSR. 



Plate 25. Marthasterites furcatus (Deflandre and Fert, 1954) Deflandre, 1959; plane views. 1, 2. Gold-coated specimens in NL and PHC; Sample 530A-79,CC; early Campanian. 3, 4. Sample 530A-89-1, 80-81 cm; PHC; Coniacian. 5. Corroded specimen; SEM. 6. Slender specimen; SEM. 7. Nearly complete specimen; SEM; Sample 530A-84,CC; late Santonian. 

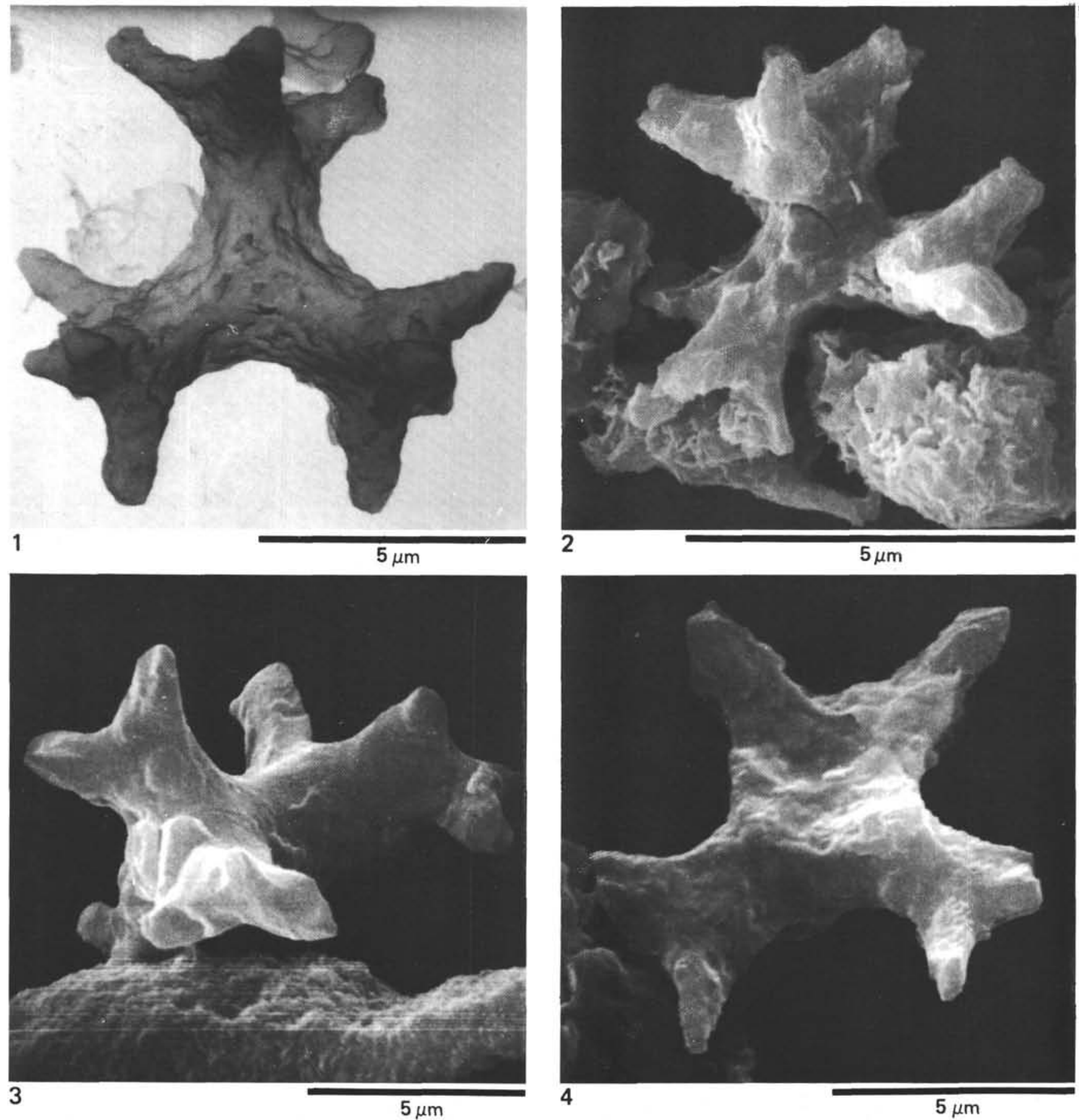

Plate 26. 1-3. Marthasterites furcatus (Deflandre and Fert, 1954) Deflandre, 1959. (1) Plane view, Sample 530A-76-5, $110-111 \mathrm{~cm}, \mathrm{SEM}$; reversed print. (2) Plane view; Sample 530A-77-2, 142-143 cm; SEM; early Campanian. (3) Lateral view; Sample 530A-84,CC; SEM. 4. Marthasterites furcatus crassus Deflandre, 1959. Plane view; Sample 530A-84,CC; late Santonian. 




$5 \mu \mathrm{m}$



$5 \mu \mathrm{m}$

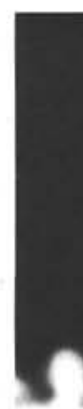

2

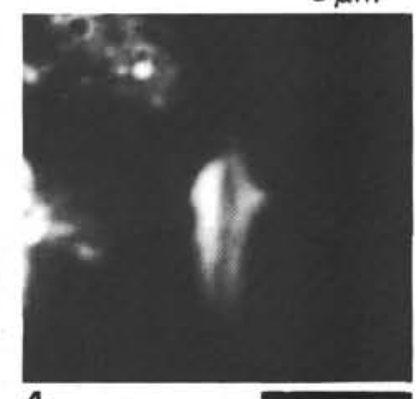

4

$5 \mu \mathrm{m}$

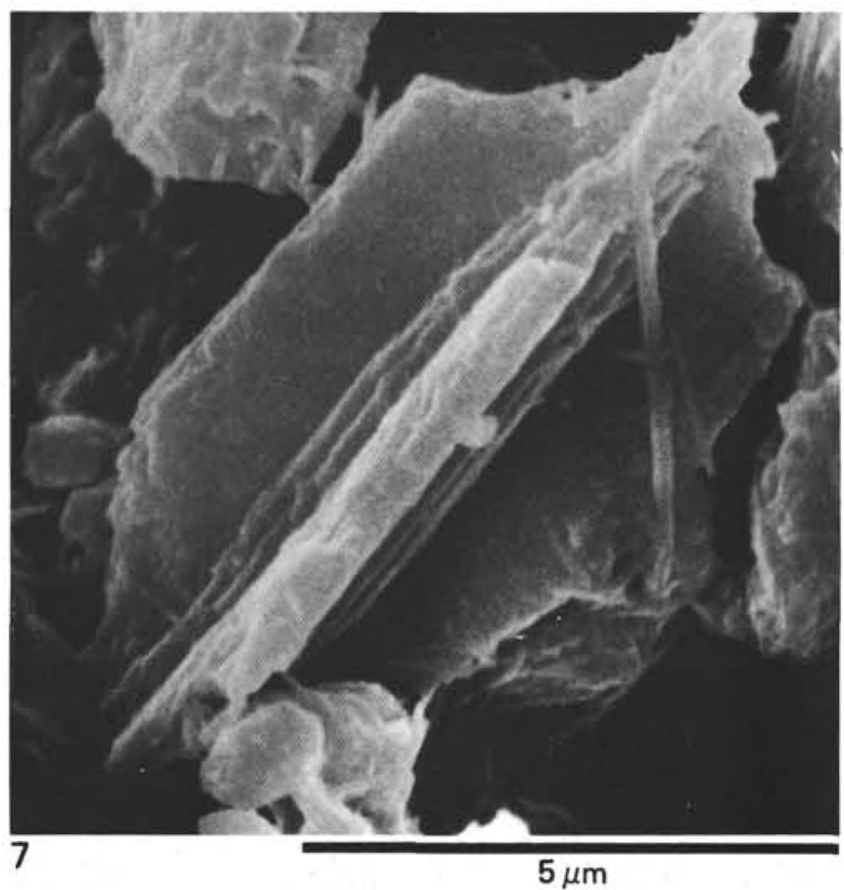

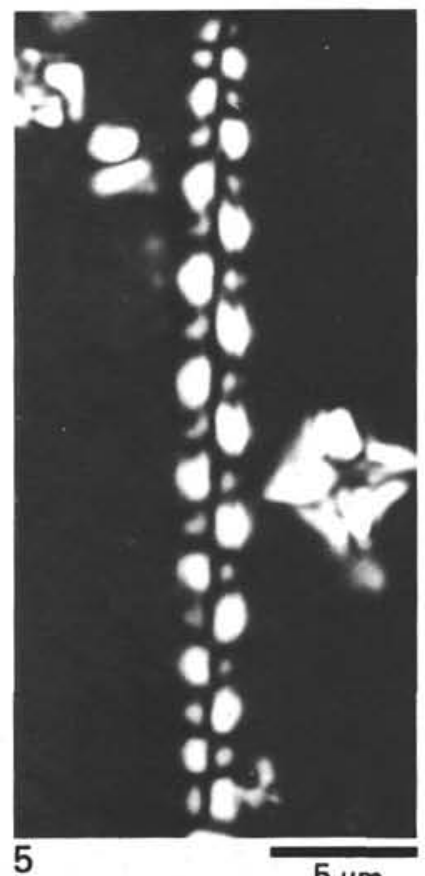

$5 \mu \mathrm{m}$



$5 \mu \mathrm{m}$

Plate 27. 1, 2, 7. Lithraphidites quadratus Bramlette and Martini, 1964; lateral views; Sample 530A-50-1, 16-17 cm. (1) PHC. (2) XN. (7) SEM. Cretaceous/Tertiary boundary. 3, 4. Lithraphidites acutum Verbeek and Manivit, 1977; lateral views. Same specimen in PHC and XN, Sample 530 A-100-2, 98-99 cm, late Cenomanian to early Turonian. 5, 6. Microrhabdulus stradneri Bramlette and Martini, 1964. Lateral view of recrystallized specimen in XN and NL; Sample 530A-50-2, 13-14 cm; Cretaceous/Tertiary boundary. 8. Lucianorhabdus cayeuxi, Deflandre 1959. Lateral view of holococcolith; SEM; Sample 530A-50-1, 16-17 cm; Cretaceous/Tertiary boundary. 

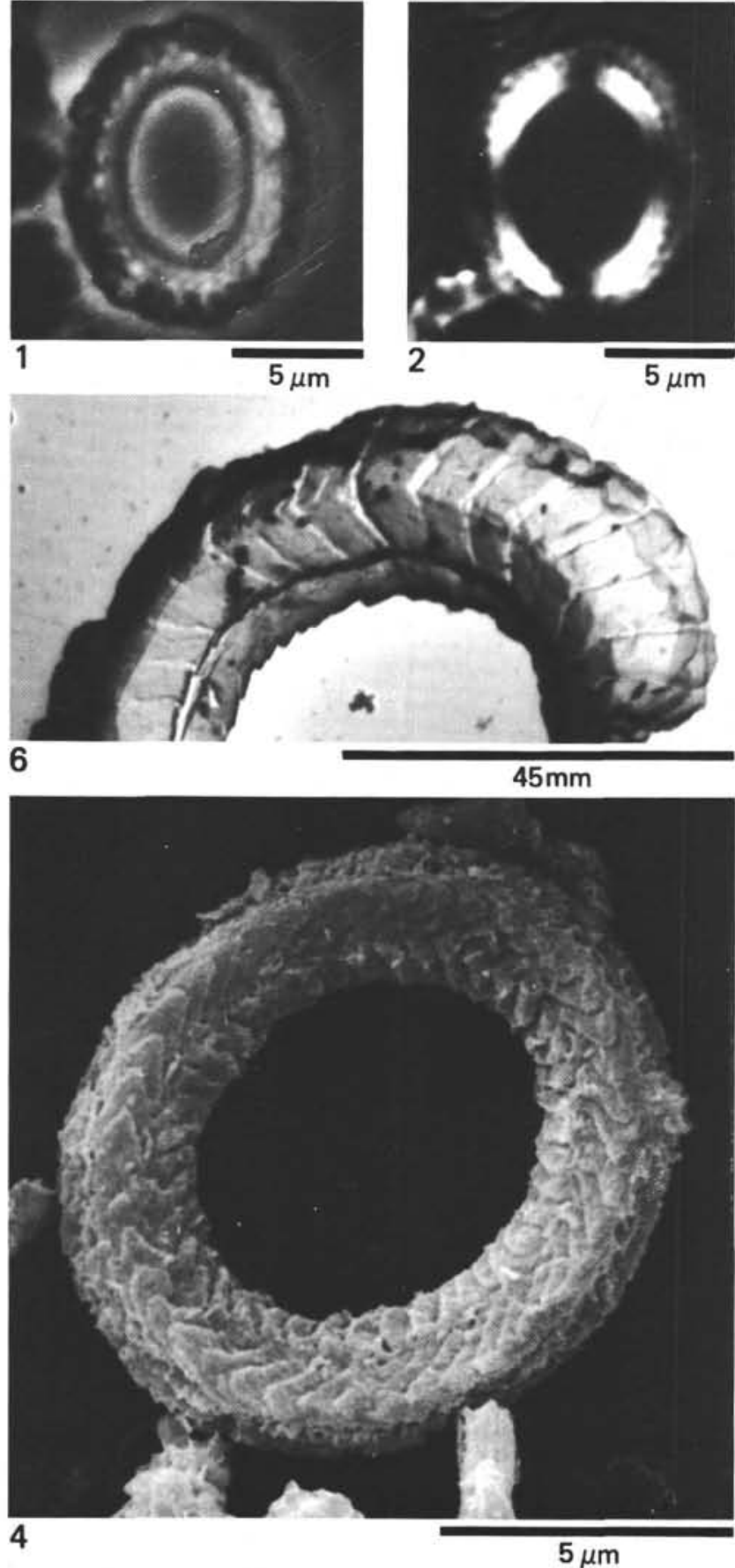


Plate 28. Manivitella pemmatoidea (Deflandre, 1965) Thierstein, 1971. 1. Plane view; Sample 530A-89-1, 80-81 cm; PHC; Coniacian. 2. Plane view; Sample 530A-79,CC; XN. 3. Plane view of distal side; Sample 530A-77-2, 142-143 cm; SEM. 4. Proximal view of slightly corroded specimen; Sample 530A-77-2, 142-143 cm; SEM. 5, 6. Plane views of distal side; Sample 530A-78,CC; TEM; early Campanian. 

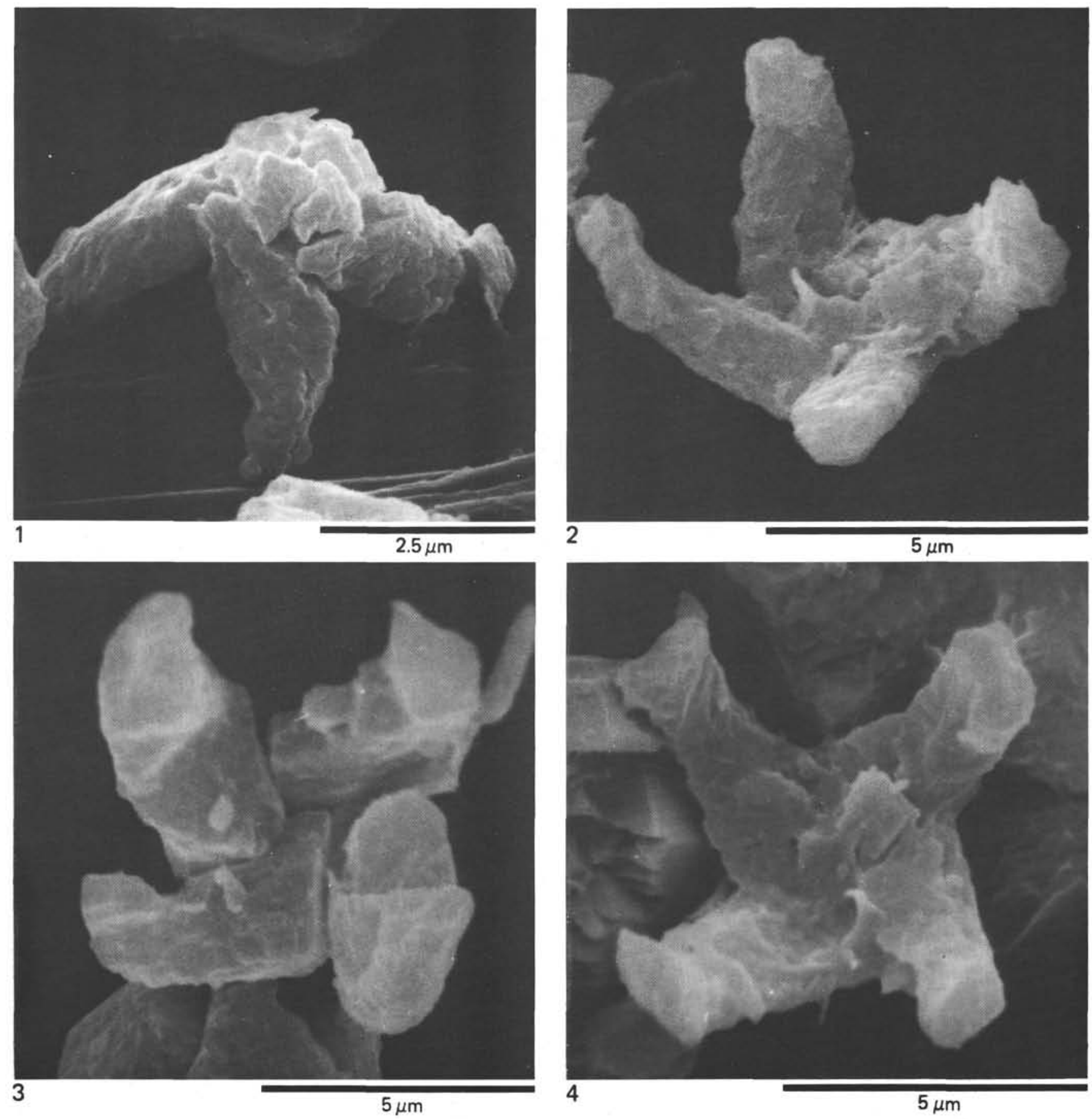

Plate 29. Micula prinsii Perch-Nielsen, 1979; SEM. 1. Oblique distal view. 2. Oblique proximal view. 3. Proximal view of recrystallized specimen. 4. Proximal view. Sample 530A-50-2, 13-14 cm; Cretaceous/Tertiary boundary. 


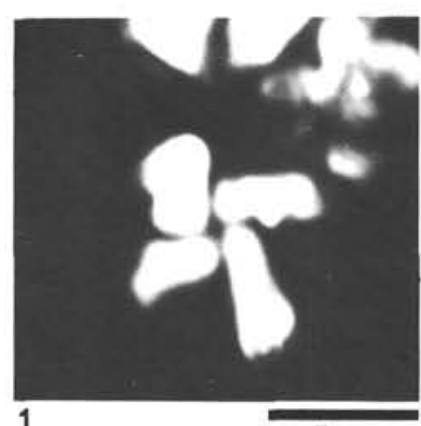

1


$1 \mu \mathrm{m}$


Plate 30. 1, 4, 7. Micula prinsii Perch-Nielsen, 1979. (1, 4) Distal and proximal view in XN; Sample 530A-50-1, 16-17 cm. (7) Distal view of etched specimen; SEM; Sample 530A-50-2, 13-14 cm. Cretaceous/Tertiary boundary. 2, 3, 5, 6. Micula murus (Martini, 1961) Bukry, 1973. (2, 3) Proximal and distal view in XN; Sample 530A-50-1, 16-17 cm. (5) Proximal view; SEM; Sample 530A-50-2, 13-14 cm. (6) Distal view; SEM; same sample. Cretaceous/Tertiary boundary. 



Plate 31. 1, 2. Micula staurophora (Gardet, 1955) Stradner, 1963. Plane views in NL; Sample 530A-50-2, 13-14 cm. 3, 5, 6. Micula swastica (Prins, 1977) Stradner and Steinmetz nov. spec. (3) Plane view; XN; paratype specimen. (5) Plane view; SEM; holotype specimen. Sample 530A50-2, 13-14 cm. (6) Plane view; Sample 530A-50-2, 13-14 cm; SEM. 4, 7. Micula praemurus (Bukry, 1973) nov. comb. (4) Plane view; Sample 530A-50-2, 13-14 cm; XN. (7) Plane view of recrystallized specimen; SEM; Sample 530A-50-2, 13-14 cm. Cretaceous/Tertiary boundary. 


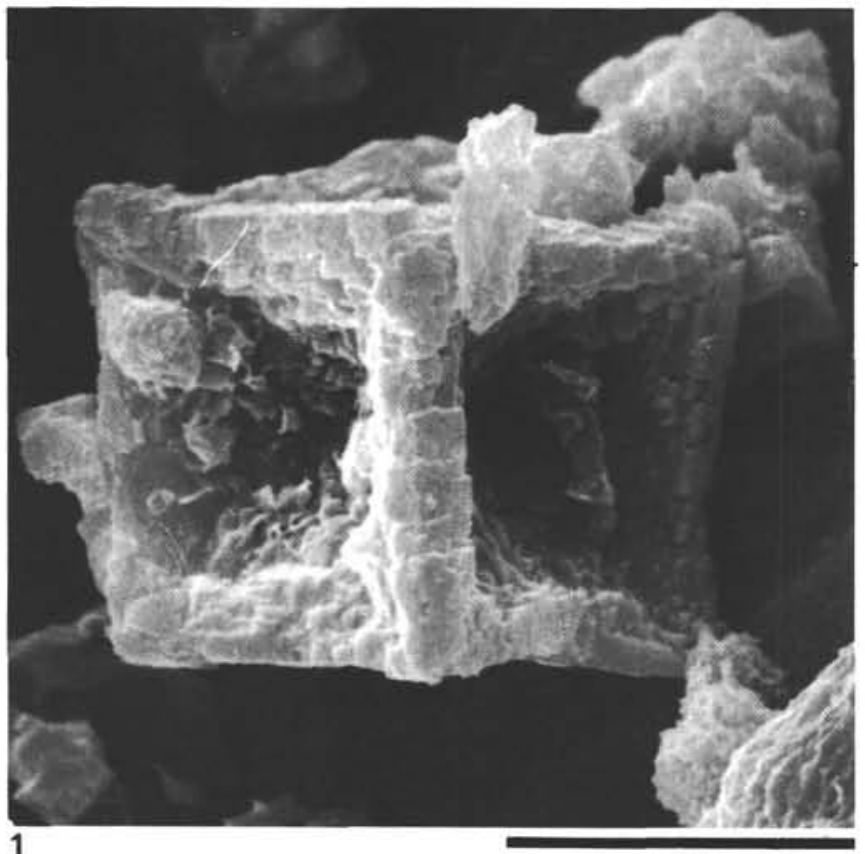

1

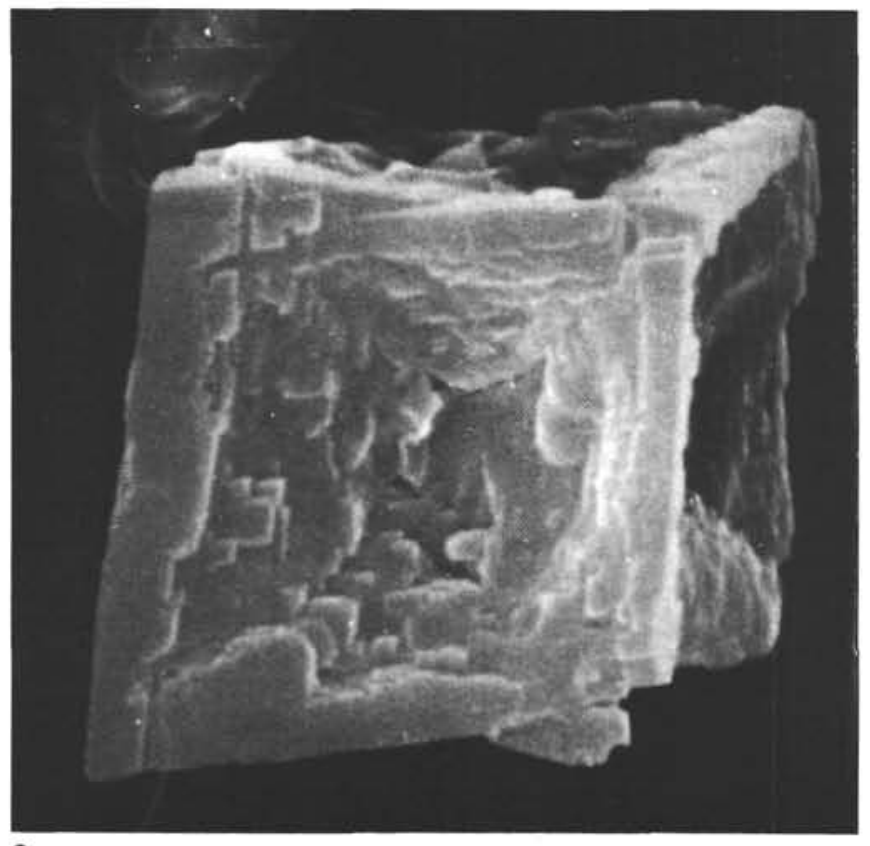

3

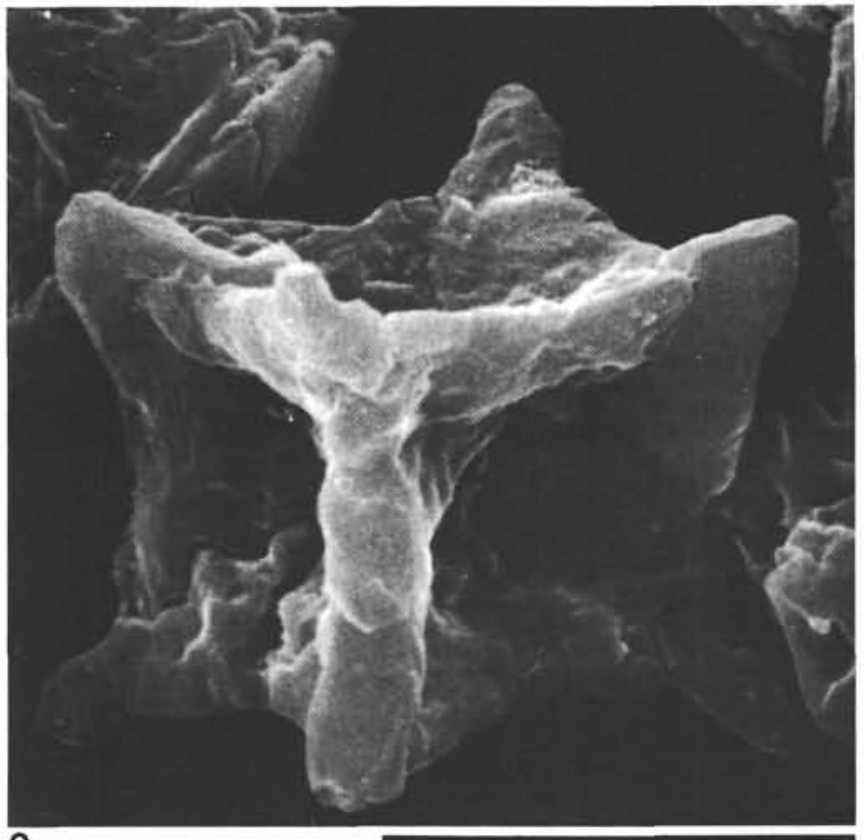

$5 \mu \mathrm{m}$

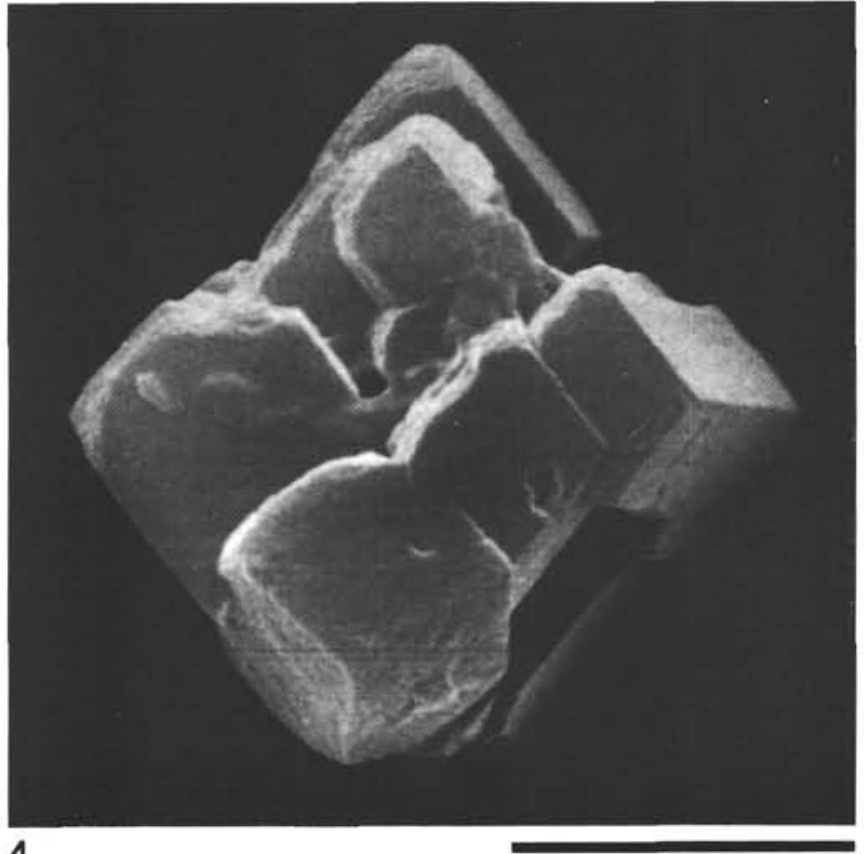

$5 \mu \mathrm{m}$

Plate 32. 1-3. Micula staurophora (Gardet, 1955) Stradner, 1963; SEM. (1) View of tilted specimen; Sample 530A-77-2, 142-143 cm. (2) Oblique side view; Sample 530A-79,CC; early Campanian. (3) Slightly tilted specimen, partly recrystallized; Sample 530A-84,CC; late Santonian. 4. Quadrum gartneri Prins and Perch-Nielsen, 1977. Heavily recrystallized specimen; SEM; Sample 530A-84,CC; late Santonian. 


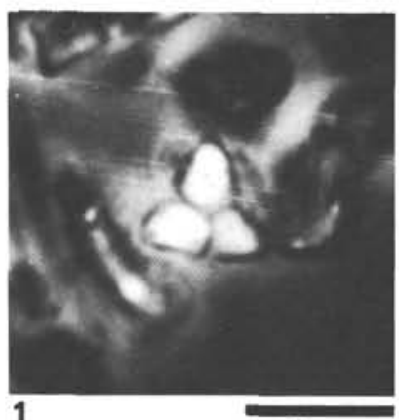

1



$5 \mu \mathrm{m}$
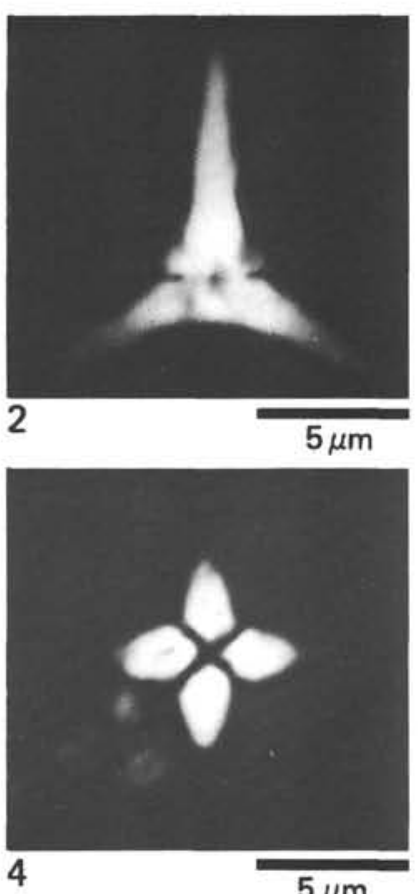

$5 \mu \mathrm{m}$

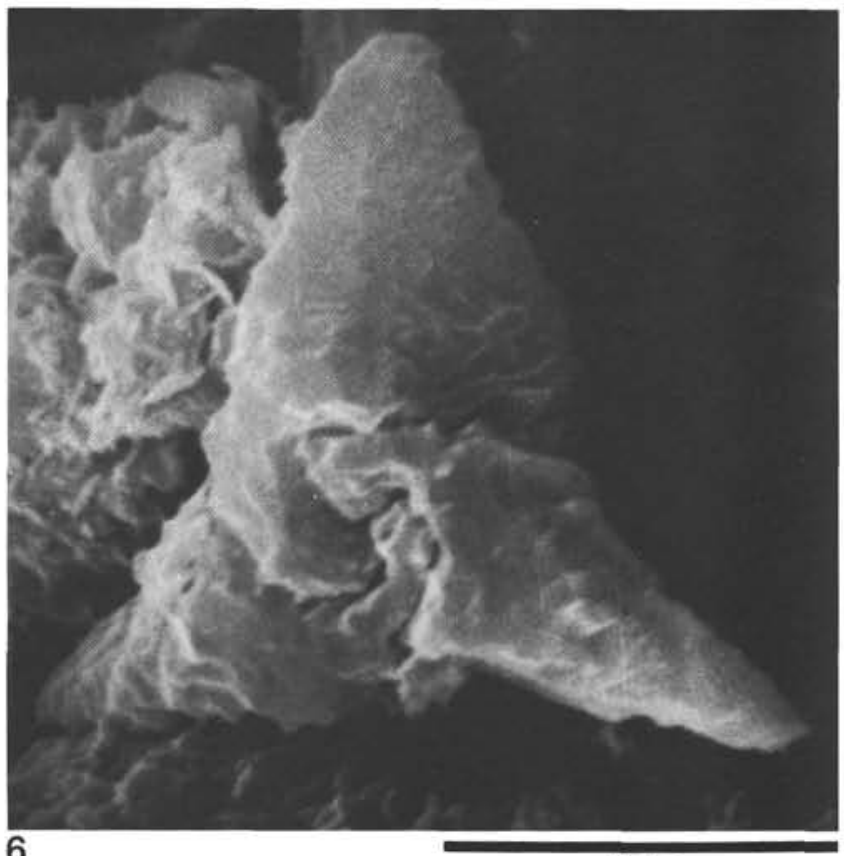

$5 \mu \mathrm{m}$

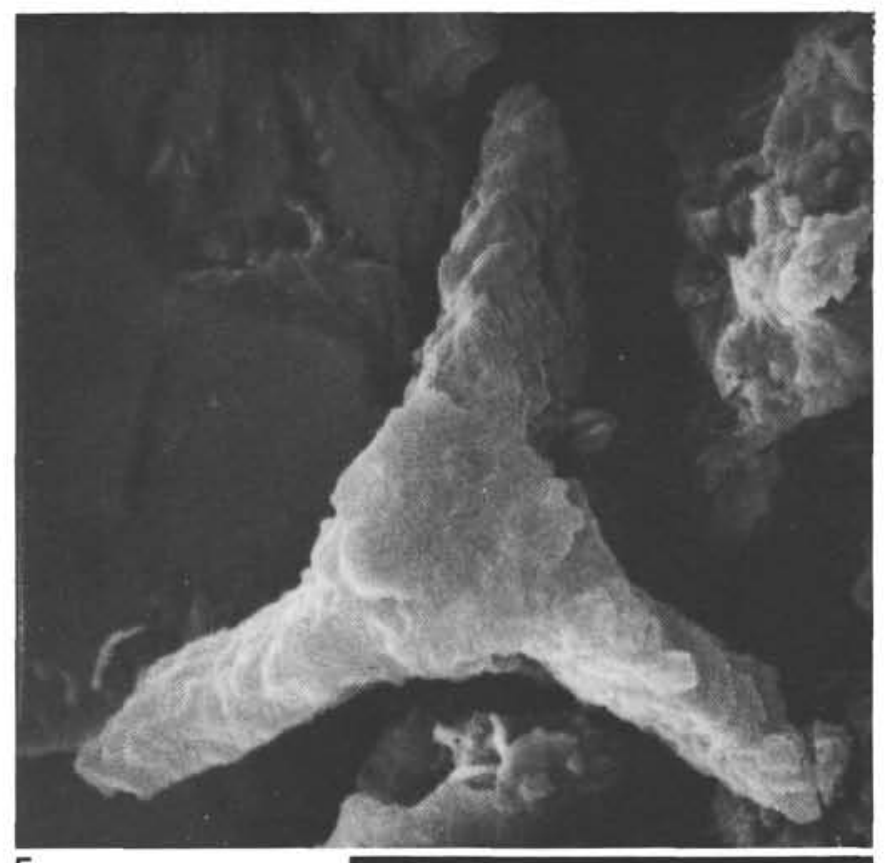

$5 \mu \mathrm{m}$

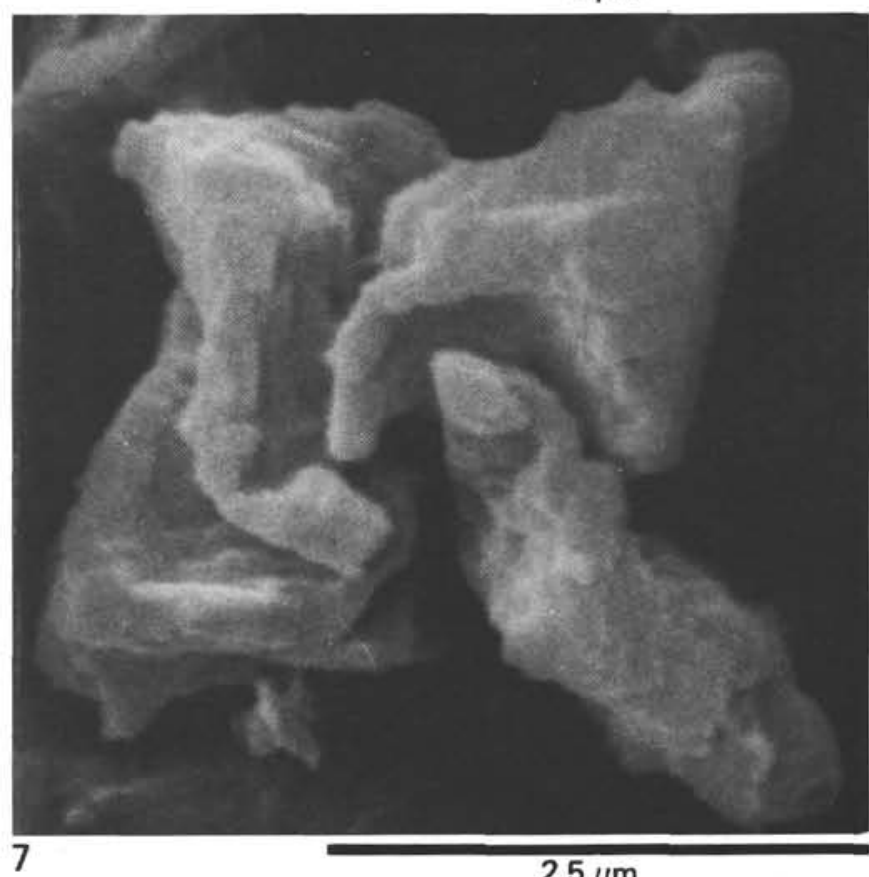

$2.5 \mu \mathrm{m}$

Plate 33. 1, 2, 5, 6. Quadrum trifidum (Stradner, 1961) Prins and Perch-Nielsen, 1977. (1) Small specimen in PHC. (2) Large specimen in XN. (5) Slender specimen, SEM. (6) Triangular specimen, slightly etched; SEM. Sample 530A-57-2, 65-66 cm; early Maestrichtian. 3, 4, 7. Quadrum gothicum (Deflandre, 1959) Prins and Perch-Nielsen, 1977. (3) Heavy "pyramidus-type" specimen; XN. (4) Slender specimen; XN. (7) Etched specimen; SEM. Sample 530A-57-2, 65-66 cm; early Maestrichtian. 




1

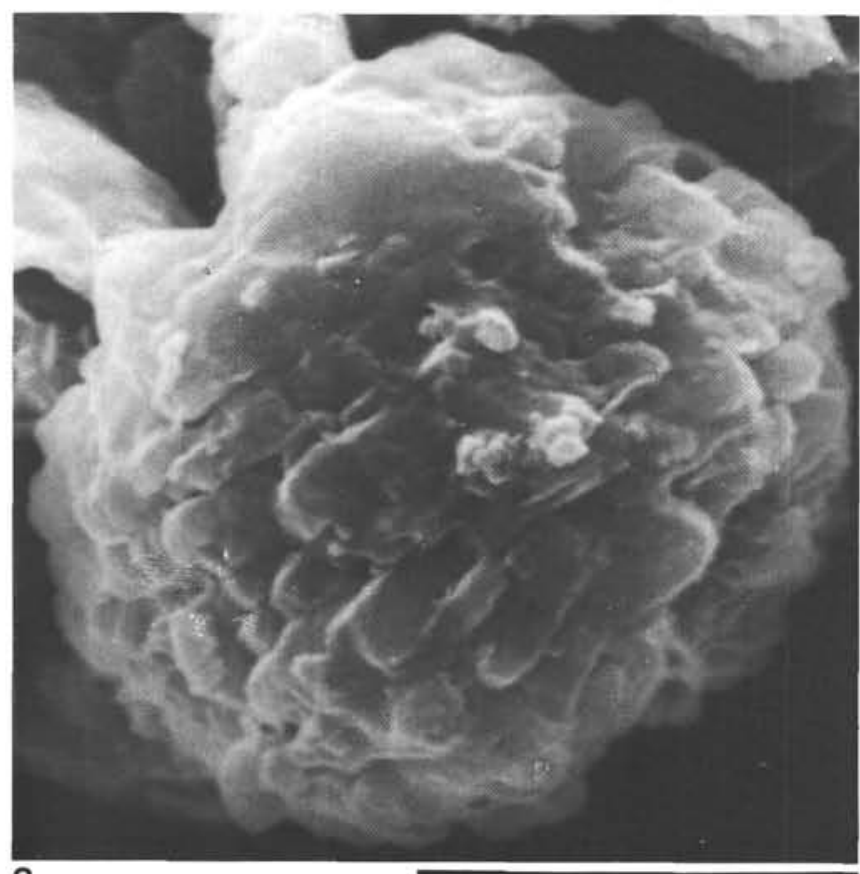

3

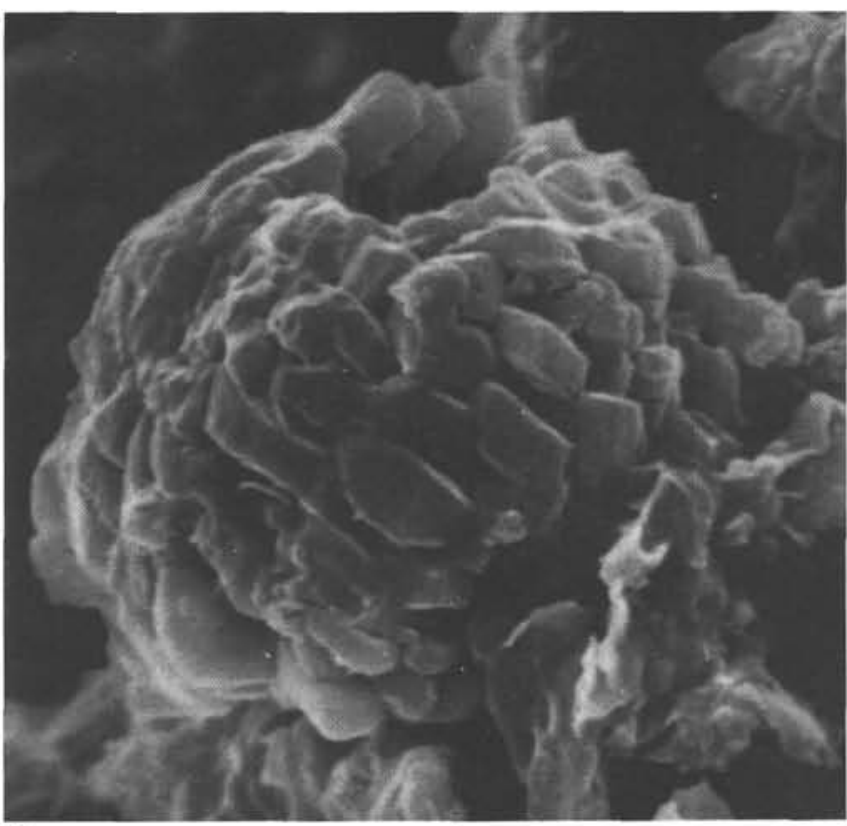

2

$5 \mu \mathrm{m}$

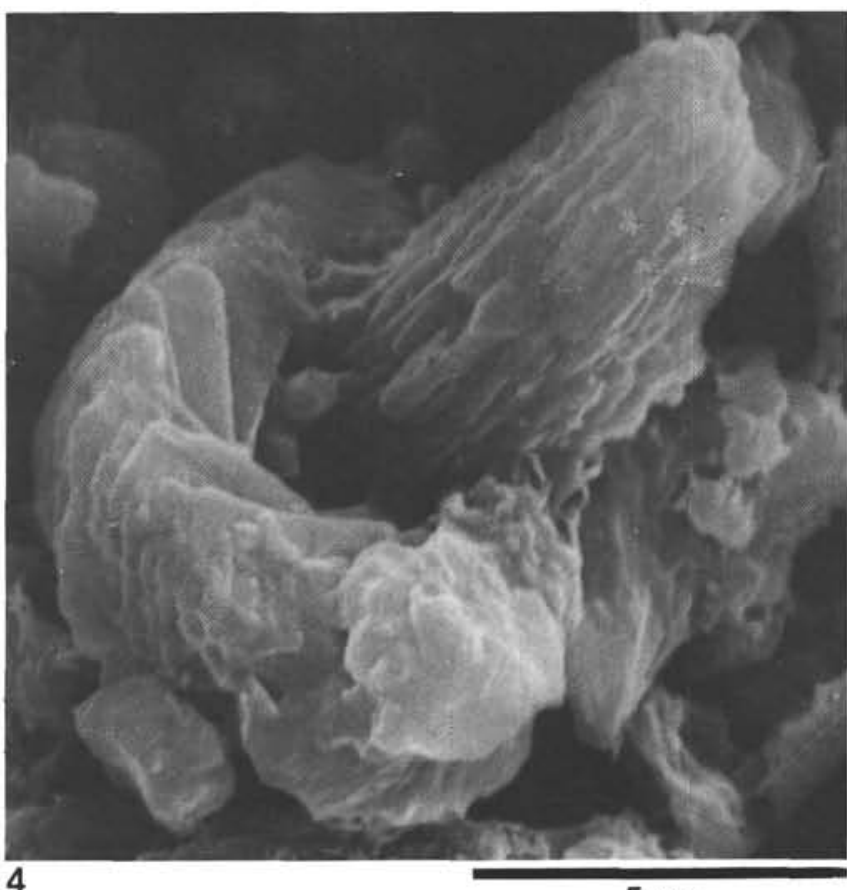

$5 \mu \mathrm{m}$

Plate 34. 1-3. Nannoconus globulus Brönnimann, 1955. (1) Oblique axial view; SEM. (2) Same specimen in lateral view; SEM. (3) Lateral view; SEM. Sample 530A-77-7, 110-111 cm; reworked Lower Cretaceous. 4. Parhabdolithus embergeri (Noël, 1958) Stradner, 1963. Oblique side view; SEM; Sample 530A-77-7, 110-111 cm; reworked Lower Cretaceous. 

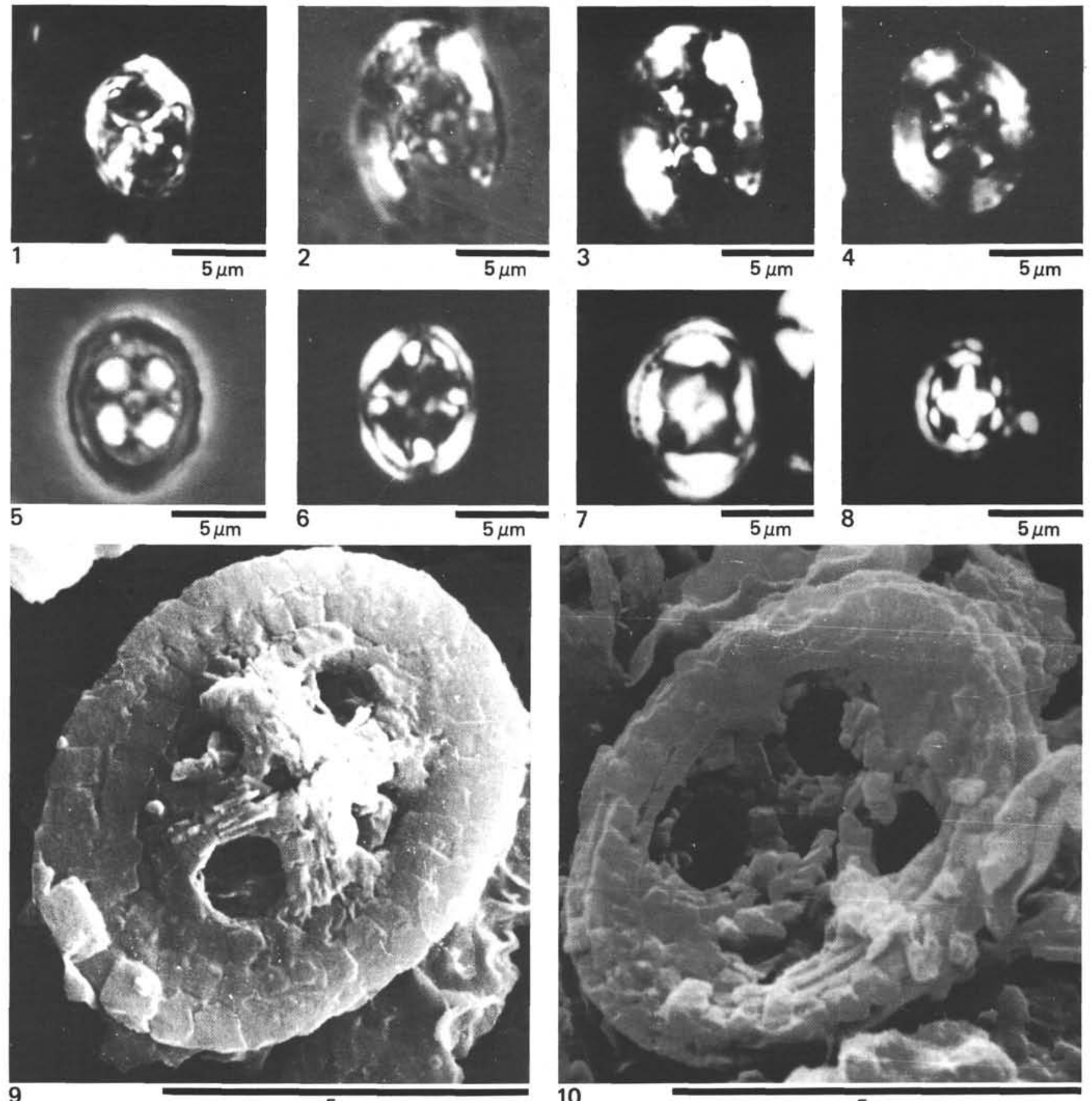

9

$5 \mu \mathrm{m}$

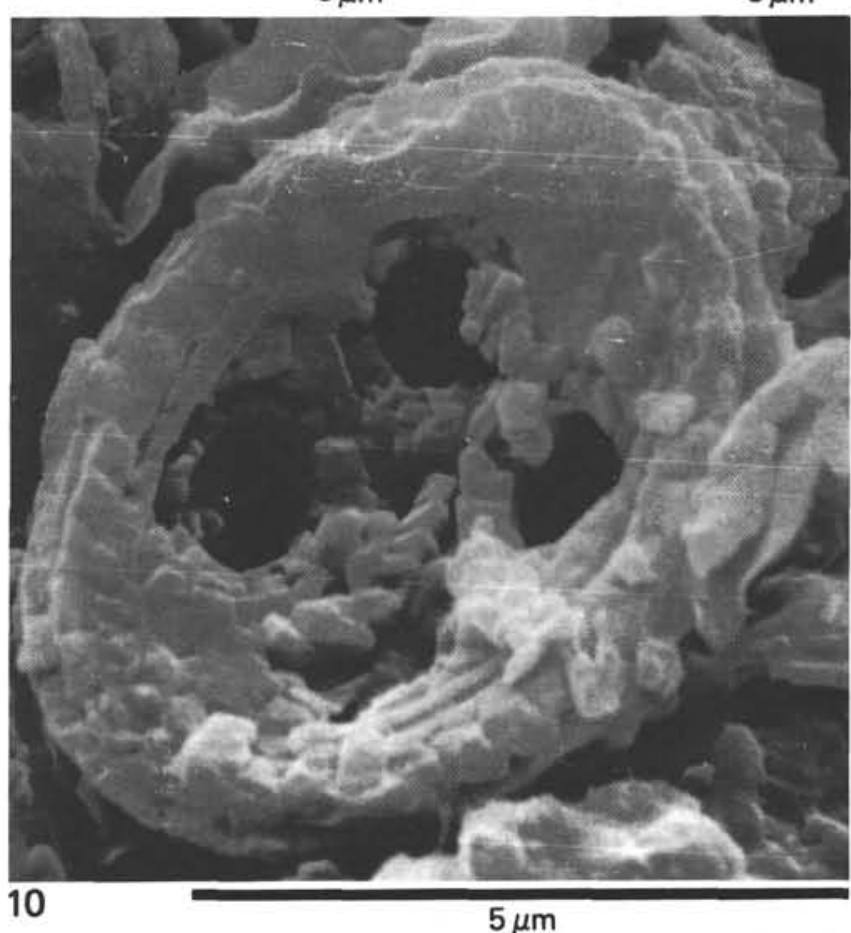

Plate 35. 1-4. Tetrapodorhabdus decorus (Deflandre and Fert, 1954) Wind and Wise, 1976. (1) Specimen with narrower peripheral ring assignable to Chiastozygus litterarius (Gorka, 1957) Manivit, 1971; compare Plate 49, Figs. 3, 5, and 6. (2, 3) Plane views in XN, plus gypsum plate, and XN; Sample 530A-105-4, 8-9 cm; late Albian. (4) Plane view; XN; Sample 530A-77-7, 110-111 cm; reworked Lower Cretaceous. 5-7, 9. Axopodorhabdus albianus (Black, 1967) Wind and Wise, 1976. (5-7) Plane views in PHC, XN, XN; Sample 530A-100-2, 98-99 cm; late Cenomanian to early Turonian. (9) Distal view; SEM. (10) Proximal view; SEM. Sample 530A-100-2, 98-99 cm; late Cenomanian to early Turonian. 8. Prediscosphaera spinosa (Bramlette and Martini, 1964) Gartner, 1968. Plane view of basal plate, XN. Sample 530A-51-1, 16-17 cm; Cretaceous/ Tertiary boundary. 

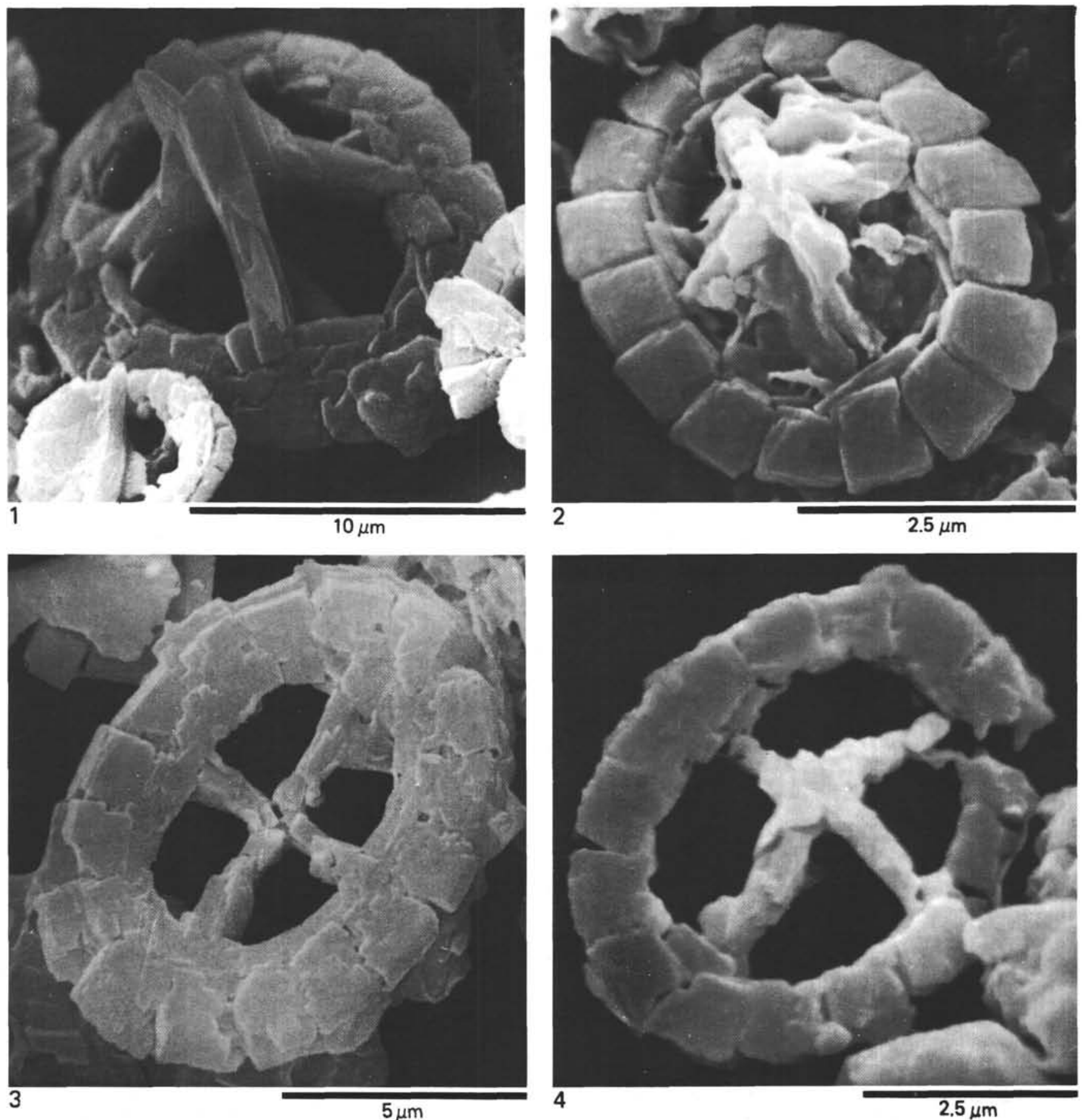

Plate 36. 1. Prediscosphaera grandis Perch-Nielsen, 1979. Oblique distal view of basal plate; SEM; Sample 530A-50-2, 13-14 cm; Cretaceous/Tertiary boundary. 2-4. Prediscosphaera spinosa (Bramlette and Martini, 1964) Gartner, 1968. (2) Distal view of basal plate; SEM; Sample 530A76-5, 110-111 cm. (3) Distal view of basal plate; SEM; Sample 530A-79,CC; early Campanian. (4) Distal view of corroded basal plate; SEM; Sample 530A-95-1, 107-108 cm; late Turonian. 


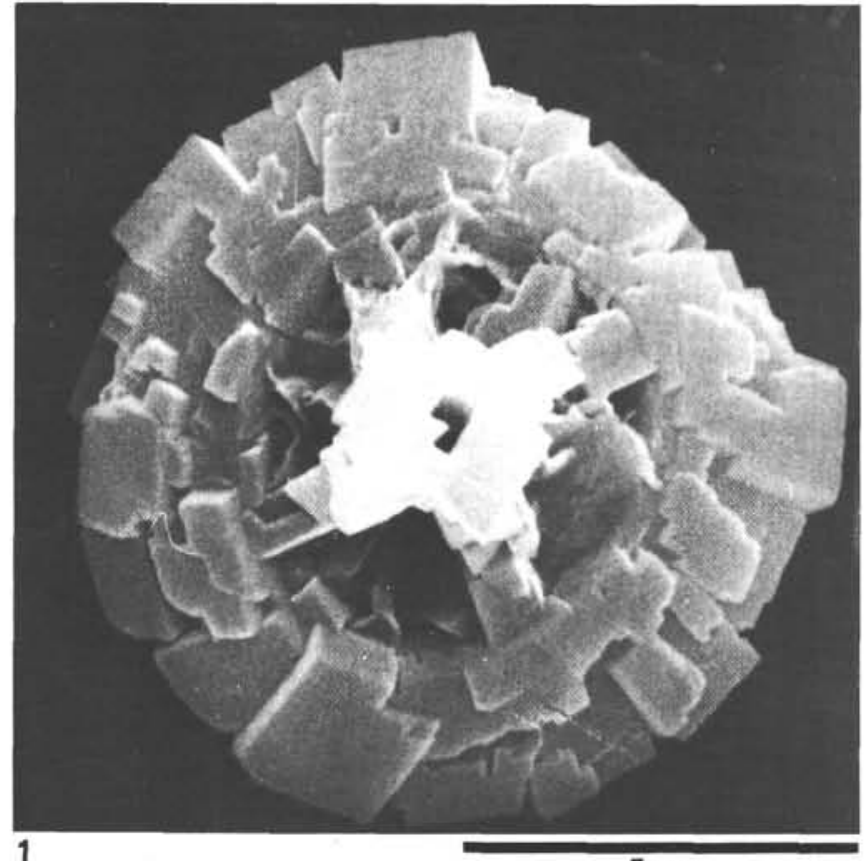

1

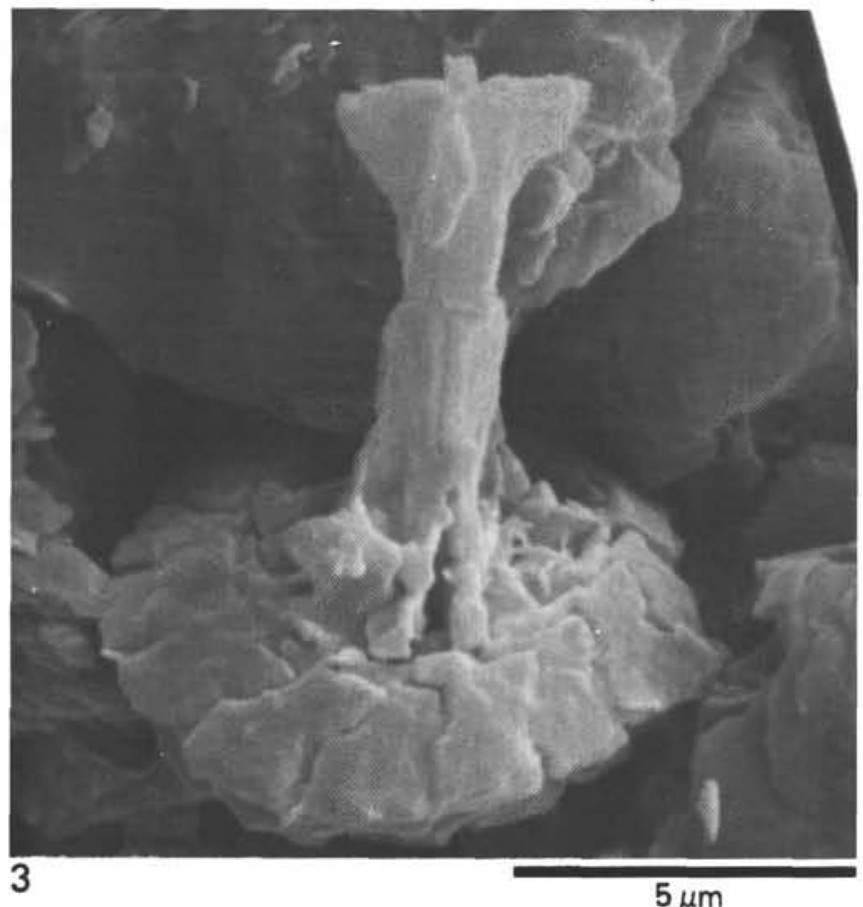

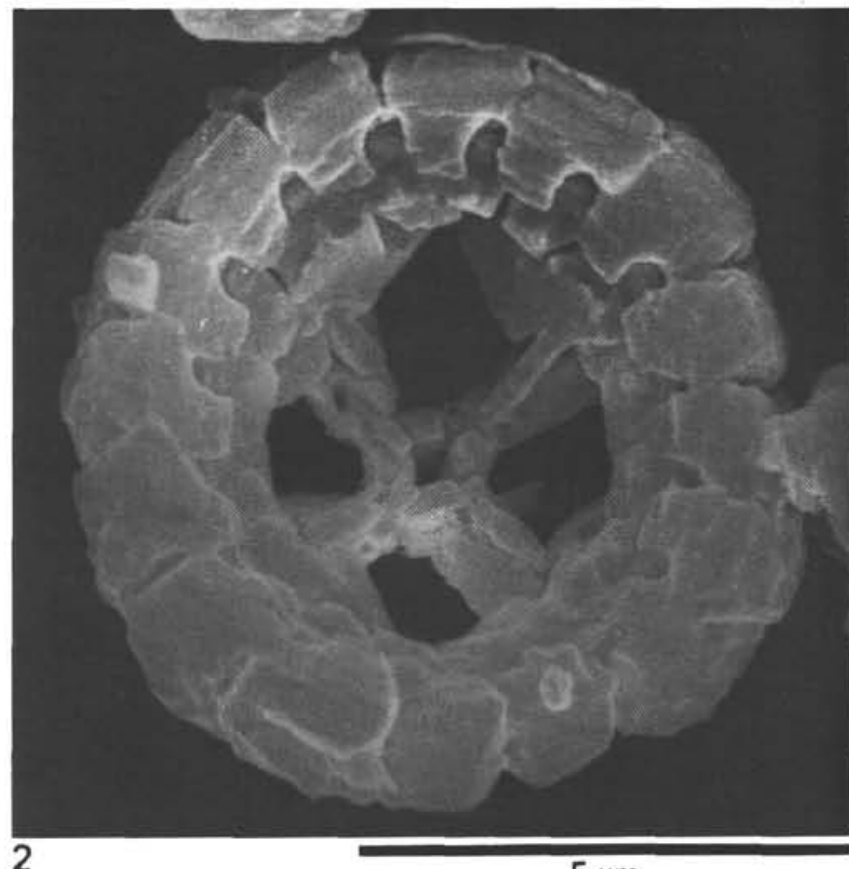

$5 \mu \mathrm{m}$

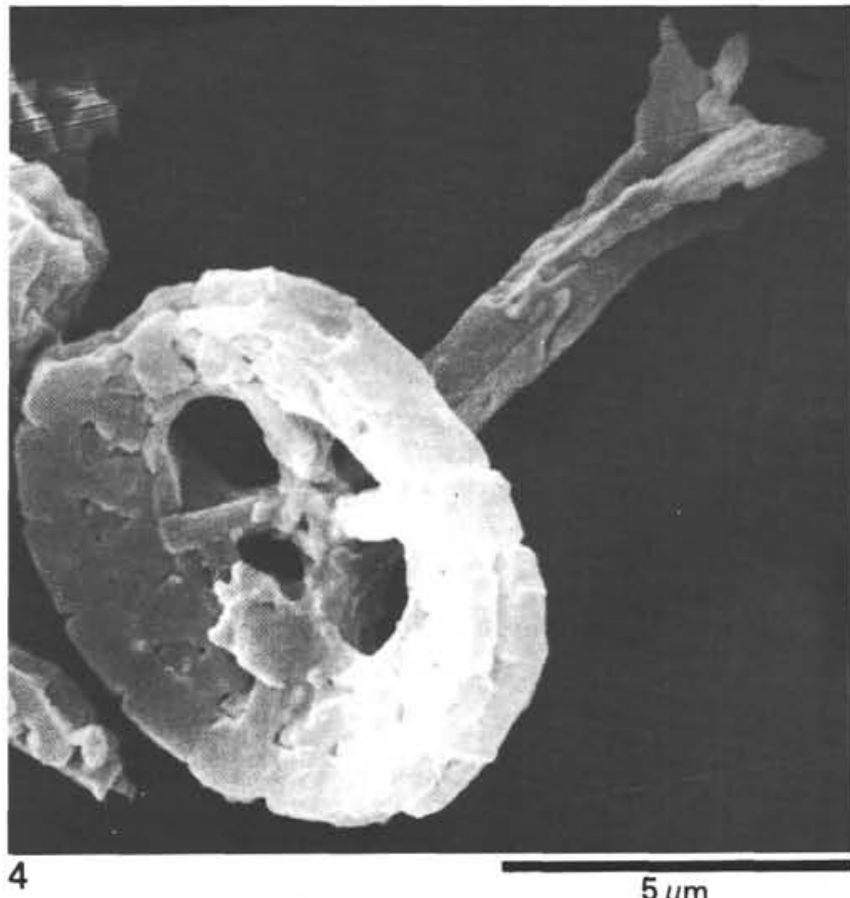

$5 \mu \mathrm{m}$

Plate 37. Prediscosphaera cretacea (Arkhangelsky, 1912) Gartner, 1968. 1. Distal view of recrystallized basal plate; SEM; Sample 530A-79,CC; early Campanian. 2. Proximal view of basal plate; SEM; Sample 530A-50-2, 13-14 cm; Cretaceous/Tertiary boundary. 3. Oblique distal view of complete coccolith; SEM; Sample 530A-77-2, 142-143 cm; early Campanian. 4. Oblique proximal view; SEM; Sample 530A-78,CC; early Campanian. 




1

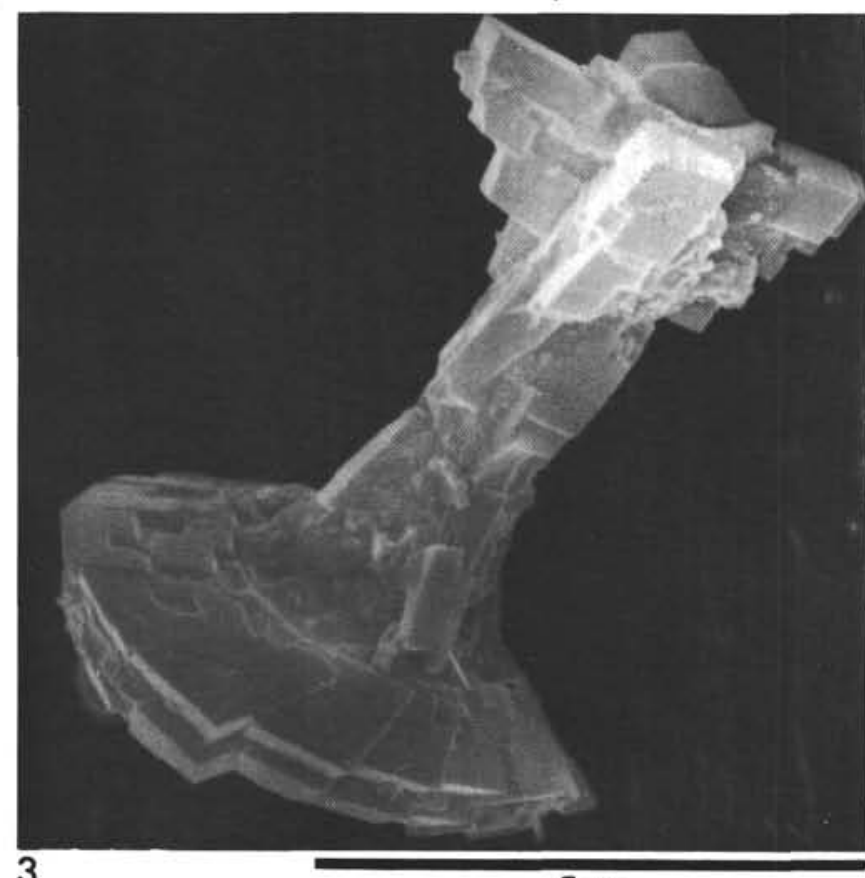

$5 \mu \mathrm{m}$

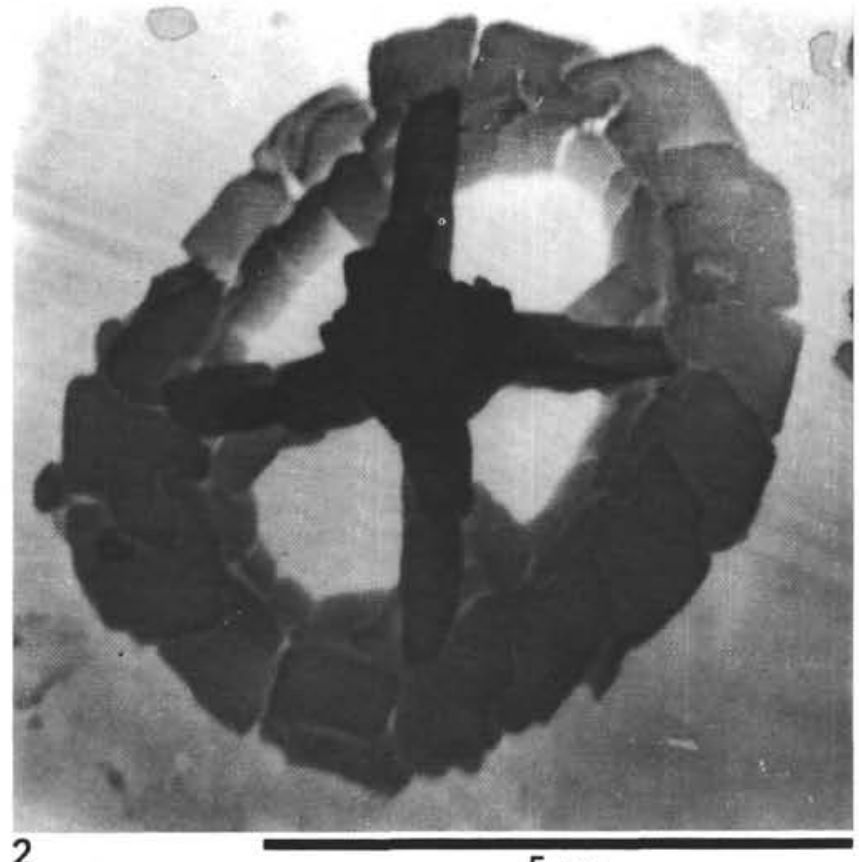

$5 \mu \mathrm{m}$

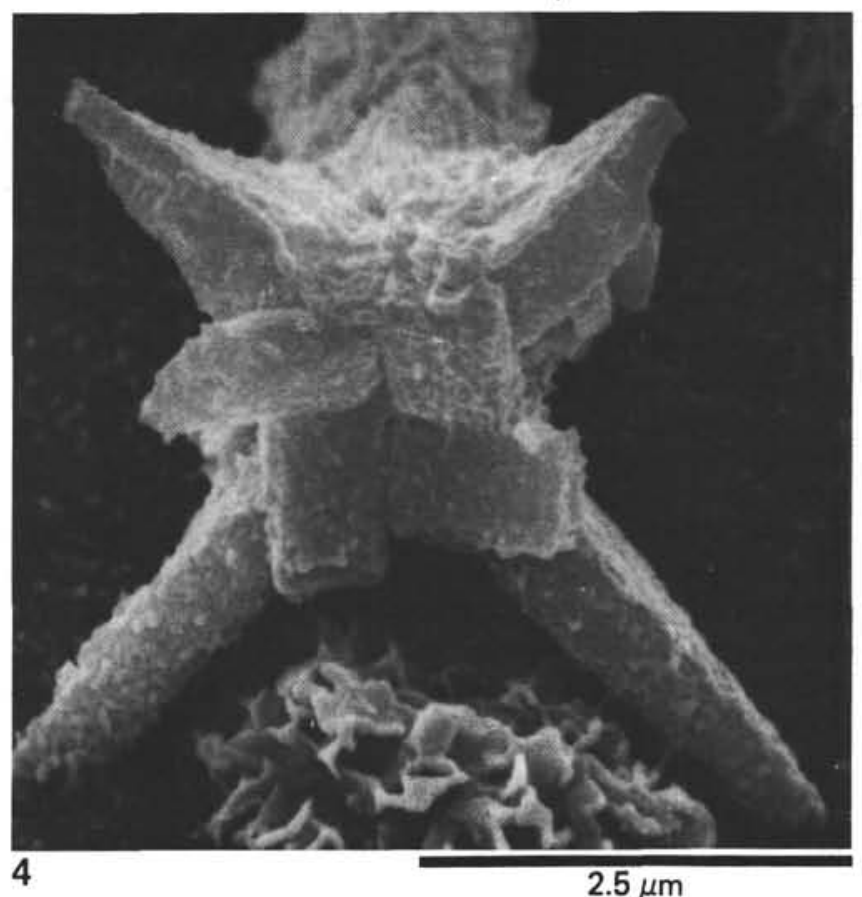

Plate 38. Prediscosphaera cretacea (Arkhangelsky, 1912) Gartner, 1968. 1. Distal view of basal plate; SEM. Sample 530A-76-5, 110-111 cm. 2. Distal view of basal plate; SEM, reversed print; Sample 530A-76-5, 110-111 cm. 3. Lateral view of complete coccolith; SEM. 4. Apical view of distal end of column; SEM; Sample 530A-77-2, 142-143 cm. Early Campanian. 

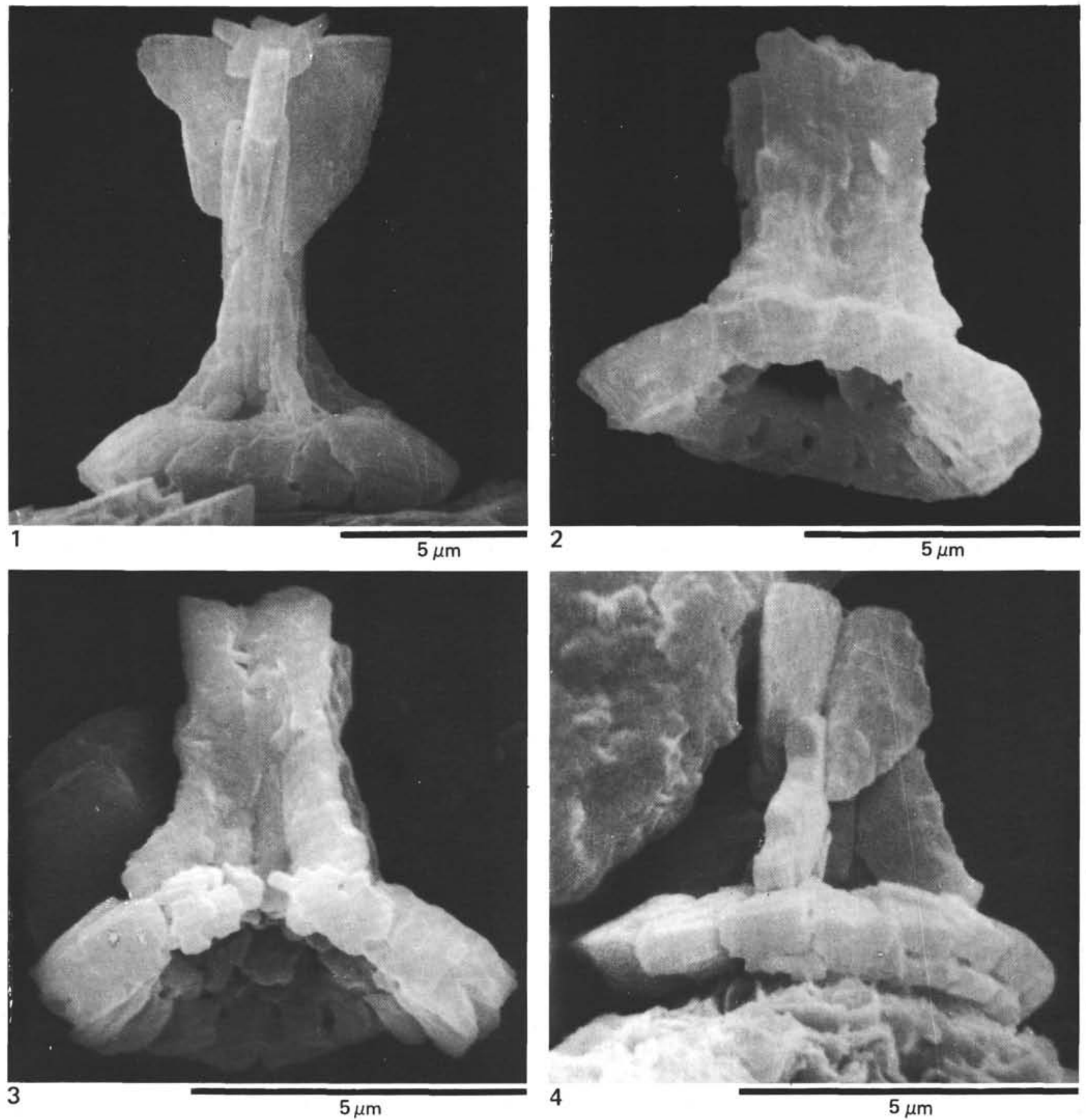

Plate 39. Prediscosphaera majungae Perch-Nielsen, 1973. 1. Lateral view of a specimen intermediary betwen $P$. majungae and $P$. cretacea; SEM; Sample 530A-50-2, 13-14 cm. 2. Lateral view; SEM; Sample 530A-50-2, 13-14 cm. 3. Lateral view; SEM; Sample 530A-50-1, 6-7 cm. 4. Lateral view of recrystallized specimen; SEM; Sample 530A-50-2, 13-14 cm. Cretaceous/Tertiary boundary. 

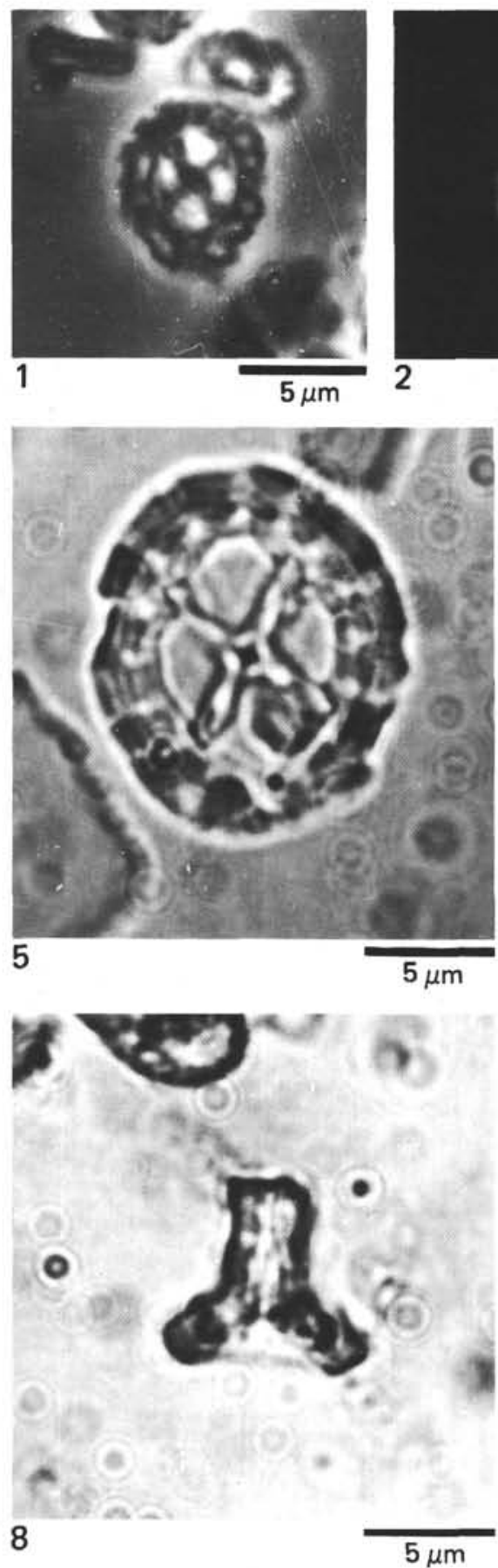

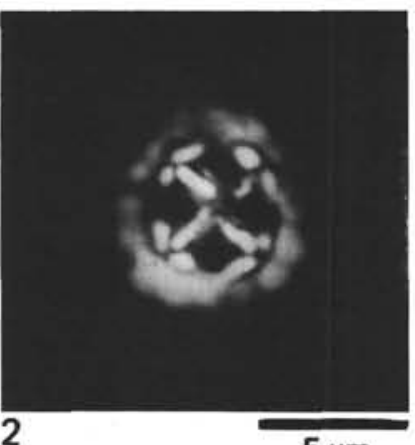

$5 \mu \mathrm{m}$
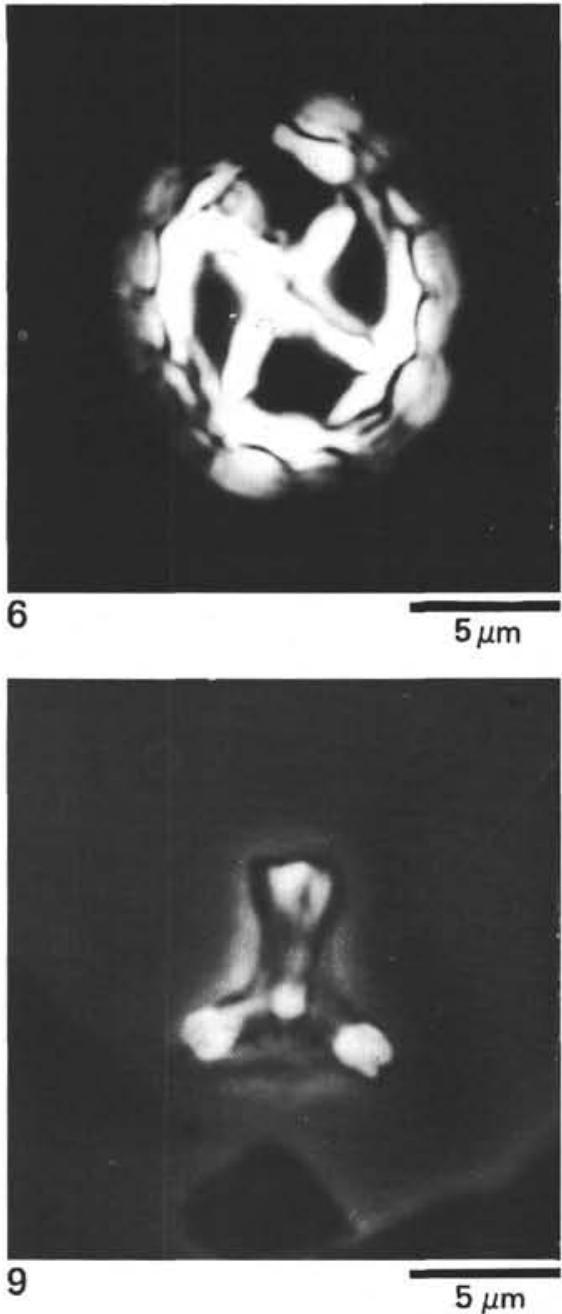

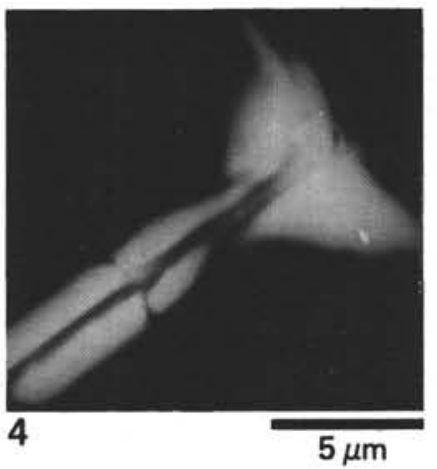

$5 \% \mathrm{~m}$
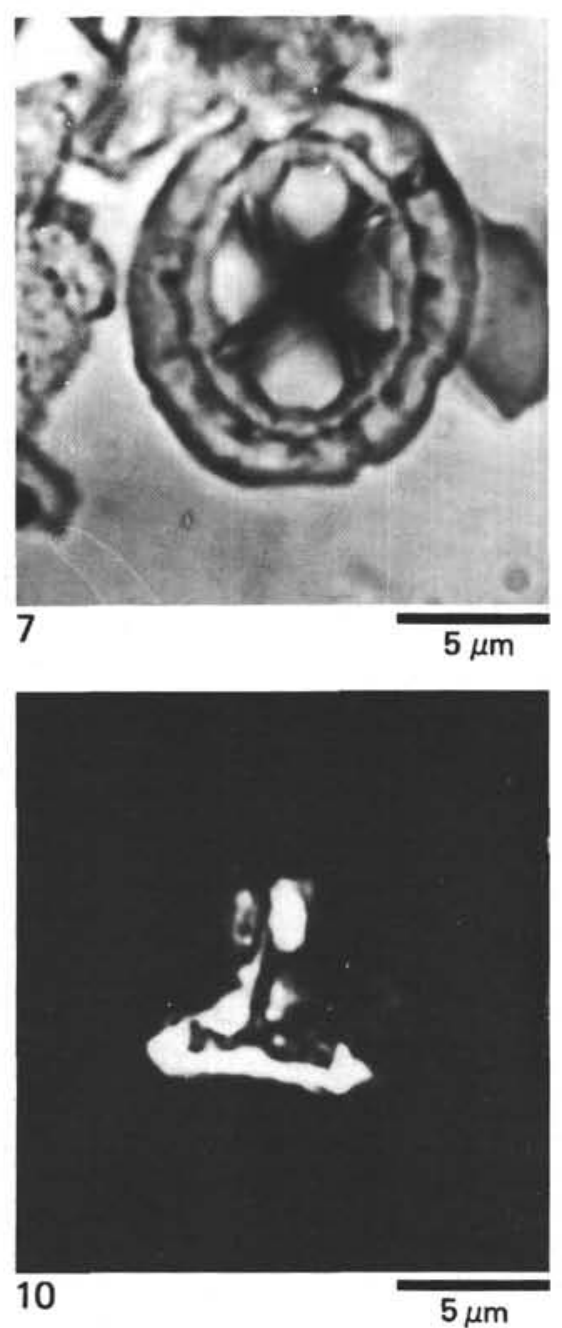

Plate 40. 1-3. Prediscosphaera cretacea (Arkhangelsky, 1912) Gartner, 1968. (1) Plane view; PHC; Sample 530A-89-1, 80-81 cm; Coniacian. (2) Plane view; XN; Sample 530A-95-1, 107-108 cm; late Turonian. (3) Lateral view of poorly preserved specimen; XN; Sample 530A-105-4, 8-9 cm; late Albian. 4-7.Prediscosphaera grandis Perch-Nielsen, 1979. (4) Lateral view of the column; XN. (5) Plane view of basal plate; NL. (6) Plane view of basal plate; XN. (7) Plane view of complete coccolith with column out of focus; NL. Sample 530A-50-1, 16-17 cm; Cretaceous/Tertiary boundary. 8-10. Prediscosphaera majungae Perch-Nielsen, 1973. (8-10) Lateral views of coccolith in NL, PHC, and XN; Sample 530A-50-1, $16-17 \mathrm{~cm}$. Cretaceous/Tertiary boundary. 

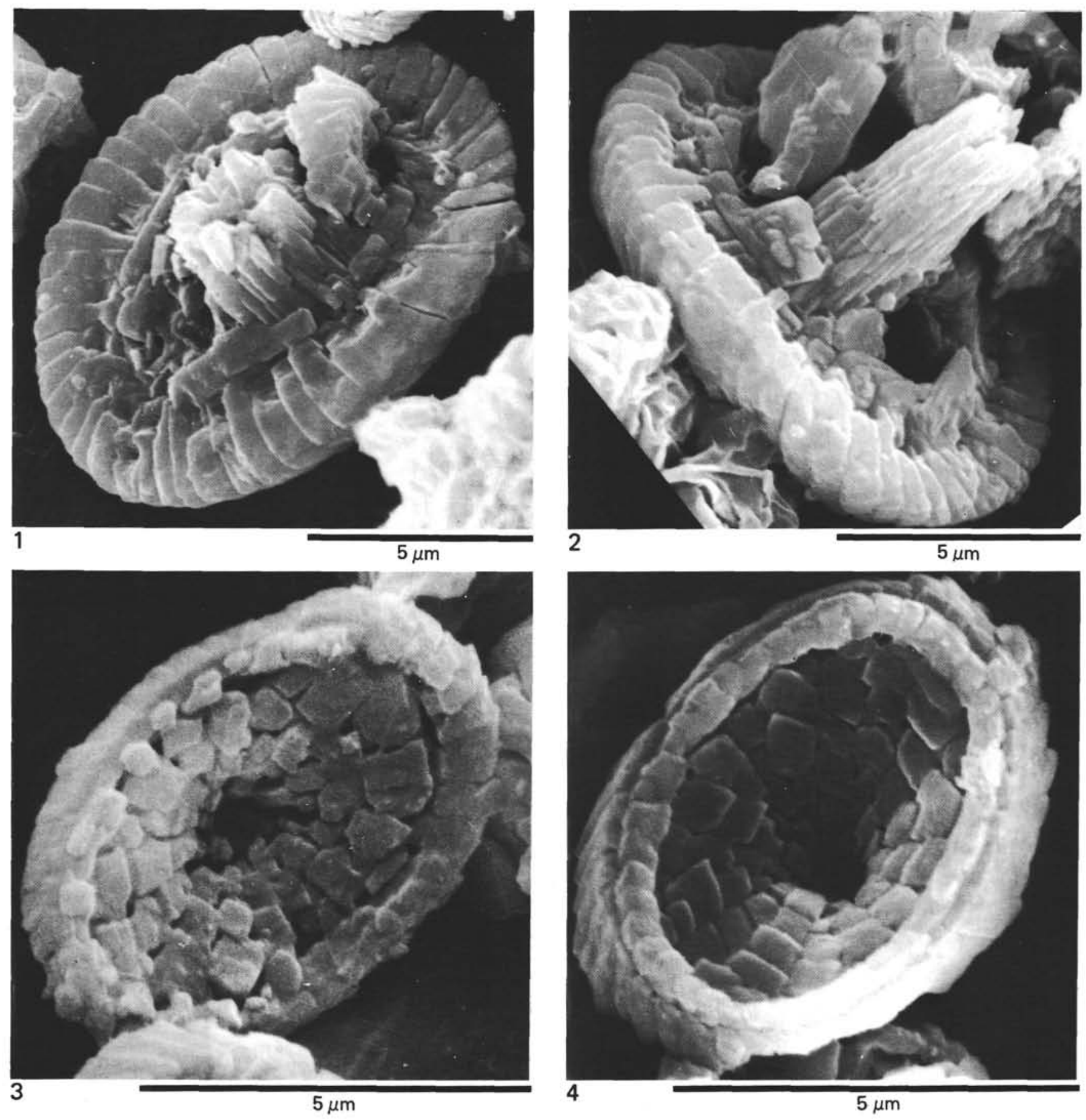

Plate 41. 1, 2. Reinhardtites anthophorus (Deflandre, 1959) Perch-Nielsen, 1968. (1) Distal view of basal plate; SEM. (2) Oblique distal view, SEM; Sample 530A-76-5, 110-111 cm; early Campanian. 3, 4. Reinhardtites mirabilis Perch-Nielsen, 1968. (3) Proximal view; SEM; Sample 530A-50-2, 13-14 cm. Cretaceous/Tertiary boundary. (4) Proximal view, SEM, Sample 530A-76-5, 110-111 cm; early Campanian. 



Plate 42. 1, 2. Polypodorhabdus schizobrachiatus (Gartner, 1968) Shafik and Stradner, 1971. Plane views of basal plate in negative PHC and XN; Sample 530A-57-2, 65-66 cm; early Maestrichtian. 3-7. Reinhardtites anthophorus (Deflandre, 1959) Perch-Nielsen, 1968. (3, 4) Plane view of specimen in NL and XN; Sample 530A-77-2, 142-143 cm; early Campanian. (5) Plane view; XN; Sample 530A-78-3, 30-31 cm; early Campanian. $(6,7)$ Plane view of specimen in PHC and XN; Sample 530A-61-4, 62-63 cm; late Campanian. 8. Reinhardtites levis Prins and Sissingh, 1977. Plane view; XN; Sample 530A-55-4, 77-78 cm; early Maestrichtian. 9, 10. Parhabdolithus embergeri (Noel, 1958) Stradner, 1963. Plane view of specimen in NL and XN; Sample 530A-95-1, 107-108 cm; late Turonian. 


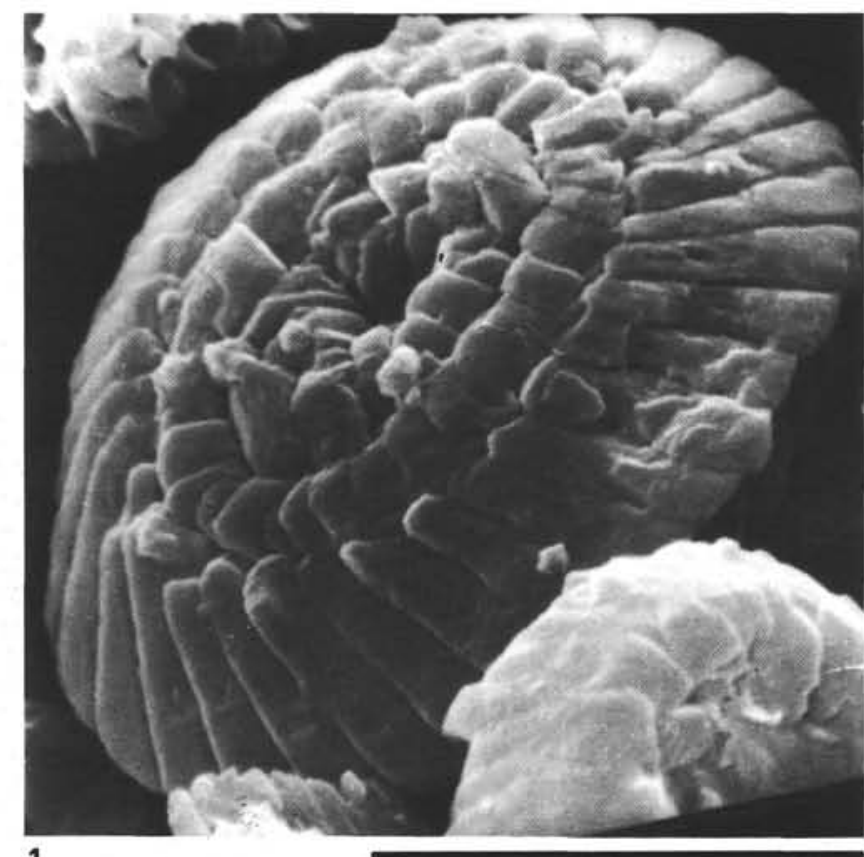

1



3

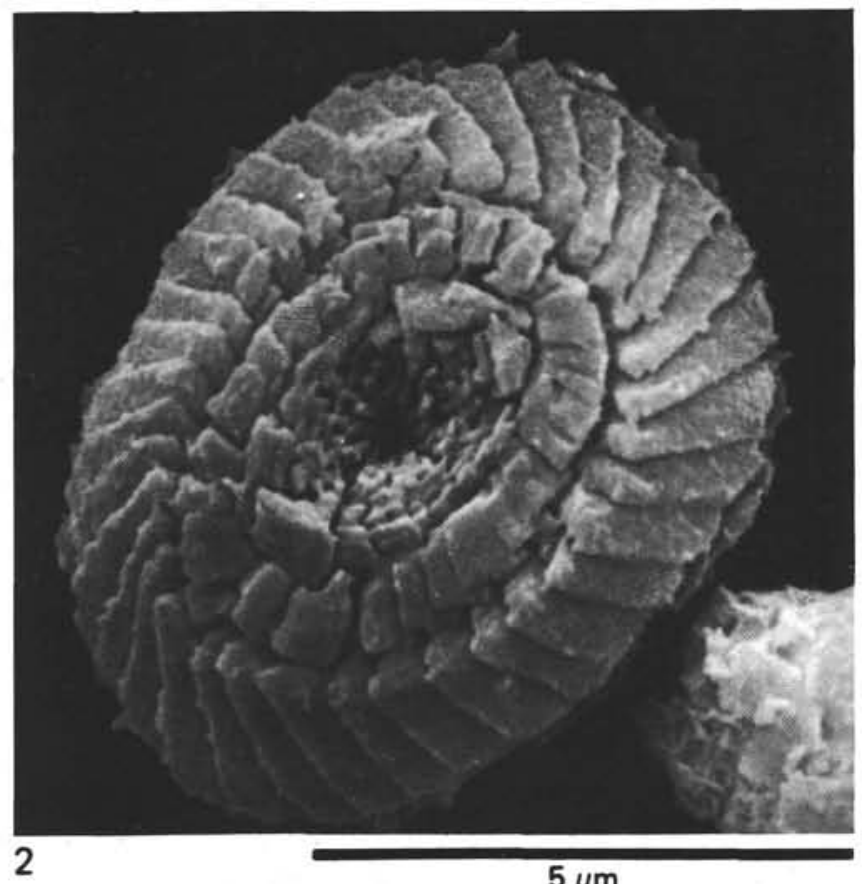

2

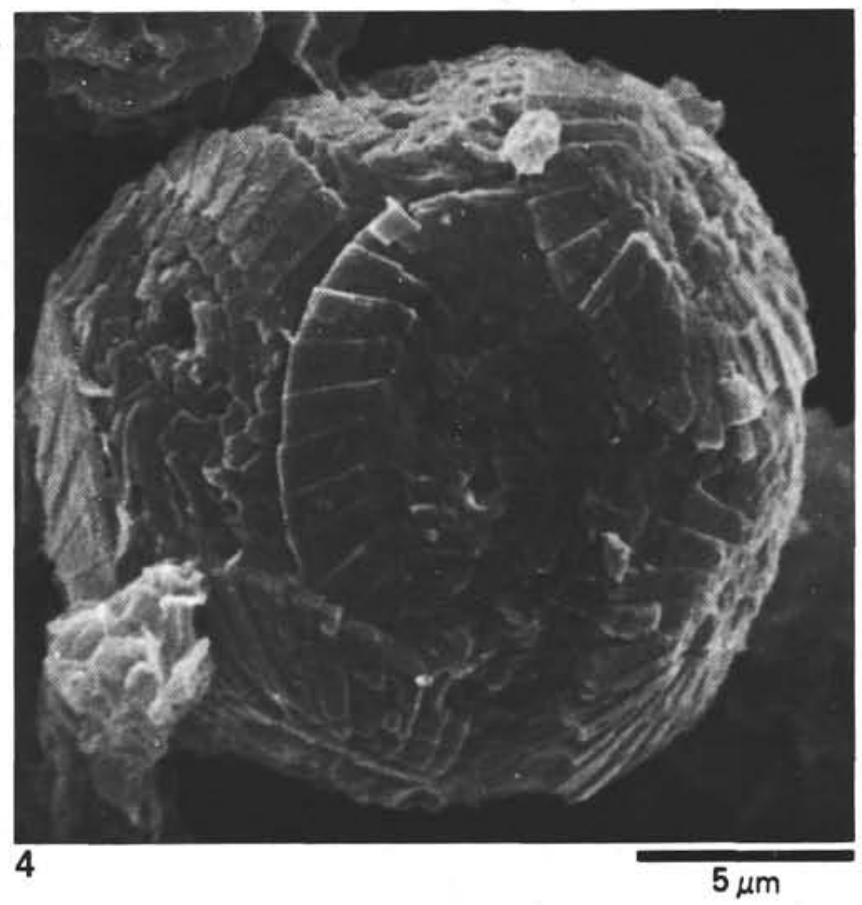

Plate 43. Watznaueria barnesae (Black, 1959) Perch-Nielsen, 1968. 1. Oblique distal view; SEM; Sample 530A-76-5, 110-111 cm. 2. Distal view; SEM; Sample 530A-77-2, 142-143 cm. 3. Proximal view; SEM; Sample 530A-78,CC. 4. View of complete coccosphere; SEM; Sample 530A-78,CC; early Campanian. 


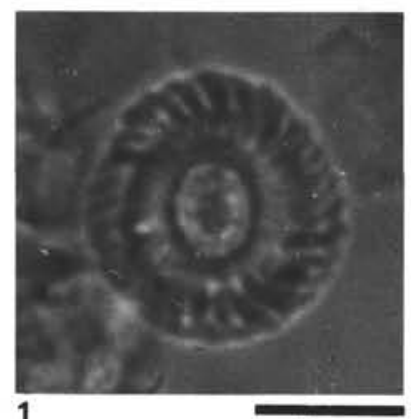

1

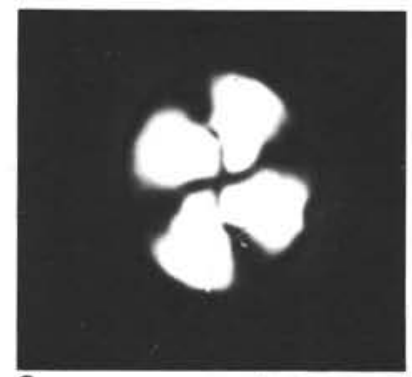

3


$5 \mu \mathrm{m}$
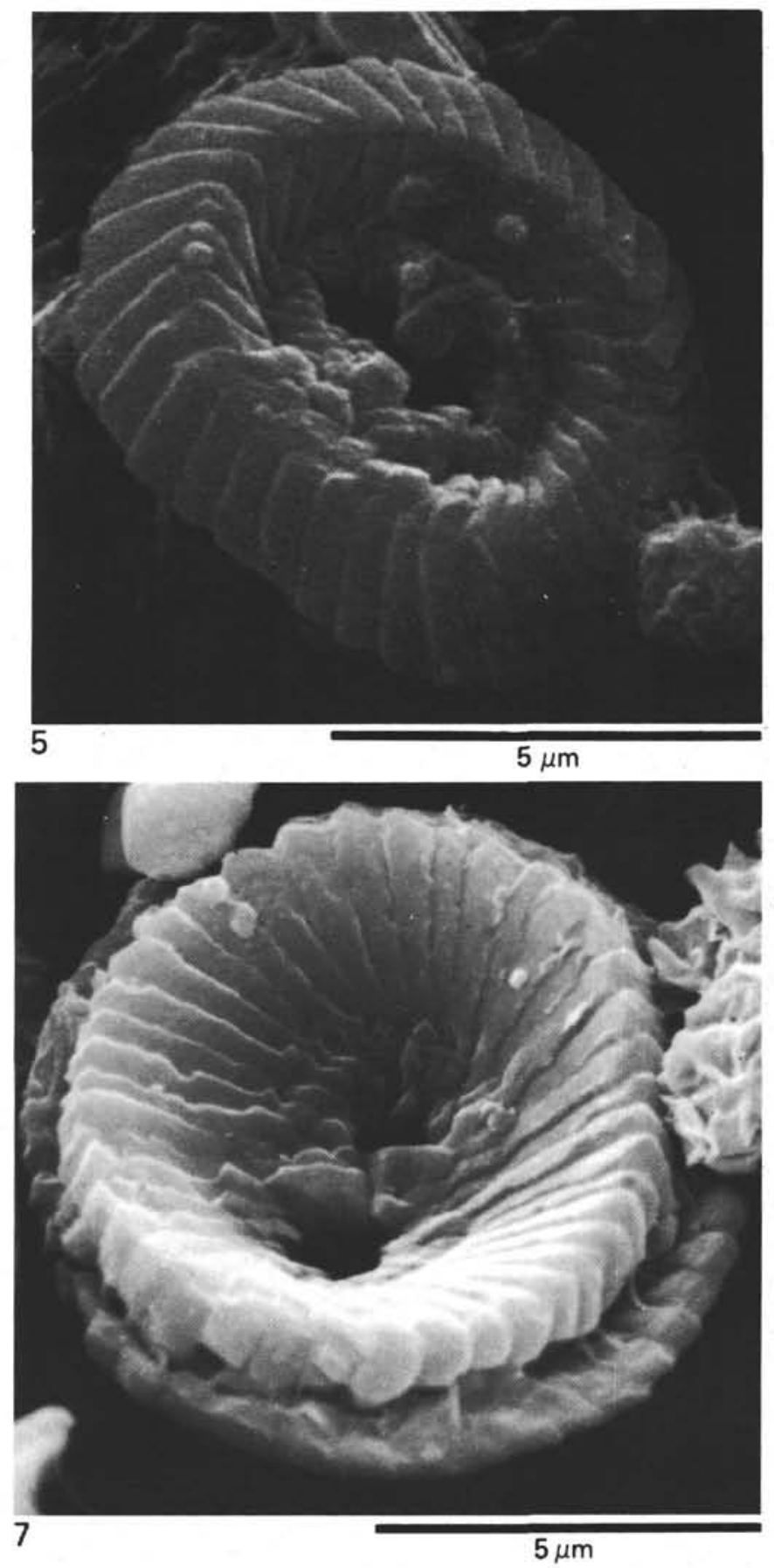

Plate 44. 1, 2. ?Watznaueria sp. Plane views in NL and XN; Samples 530A-50-2, 13-14 cm and 530A-50-1, 16-17 cm; Cretaceous/Tertiary boundary. 3, 4. Watznaueria barnesae (Black, 1959) Perch-Nielsen, 1968. (3) PHC; (4) XN; Samples 530A-78-3, 30-31 cm, early Campanian, and 530A-100-2, 98-99 cm, late Cenomanian to early Turonian. 5-7. Watznaueria biporta Bukry, 1969. (5) Oblique distal view; Sample 530A-76-2, 110-111 cm; early Campanian; SEM. (6) Distal view; SEM; Sample 530A-77-2, 142-143 cm; early Campanian. (7) Proximal view; SEM; Sample 530A-76-5, 110-111 cm; early Campanian. 



Plate 45. 1. Tranolithus orionatus (Reinhardt) Reinhardt, 1966. Distal view; SEM; Sample 530A-78,CC; early Campanian. 2, 3. Zygodiscus biclavatus Bukry, 1969. (2) Distal view of poorly preserved specimen; SEM; Sample 530A-76-5, 110-111 cm; early Campanian. (3) Distal view; SEM; Sample 530A-77-2, 142-143 cm; early Campanian. 4. Zygodiscus theta (Black, 1959) Bukry, 1969. Distal view; SEM; Sample 530A-94-2, $87-88 \mathrm{~cm}$; early Coniacian. 




1

$5 \mu \mathrm{m}$
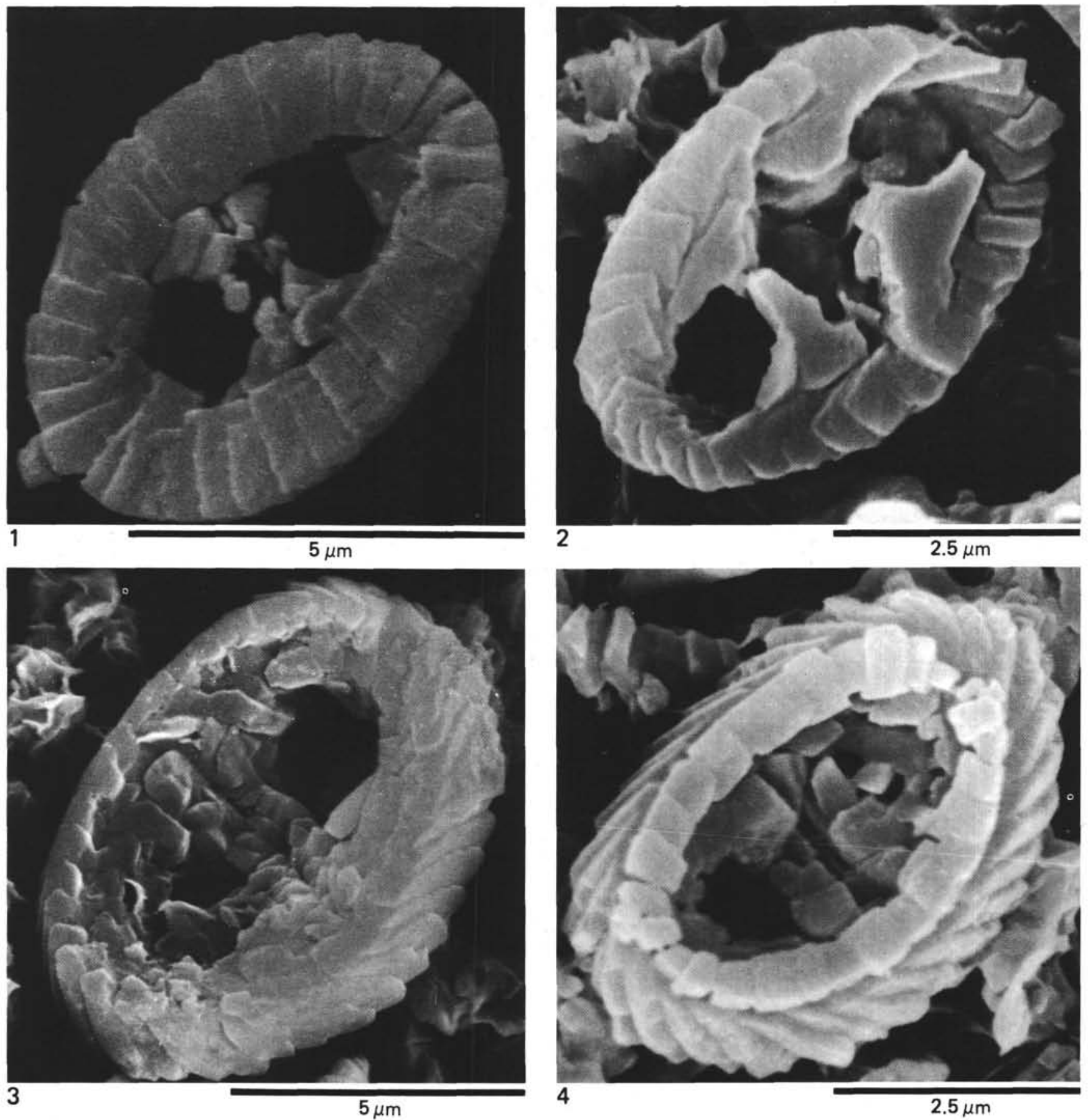

Plate 46. 1. Zygodiscus spiralis Bramlette and Martini, 1964. Distal view; SEM; Sample 530A-50-2, 13-14 cm, Cretaceous/Tertiary boundary. 2. Zygodiscus biclavatus Bukry, 1969. Distal view; SEM; Sample 530A-76-5, 110-111 cm; early Campanian. 3, 4. Zygodiscus diplogrammus (Deflandre and Fert, 1954) Gartner, 1968. Proximal views; SEM; Sample 530A-76-5, 110-111 cm; early Campanian. 

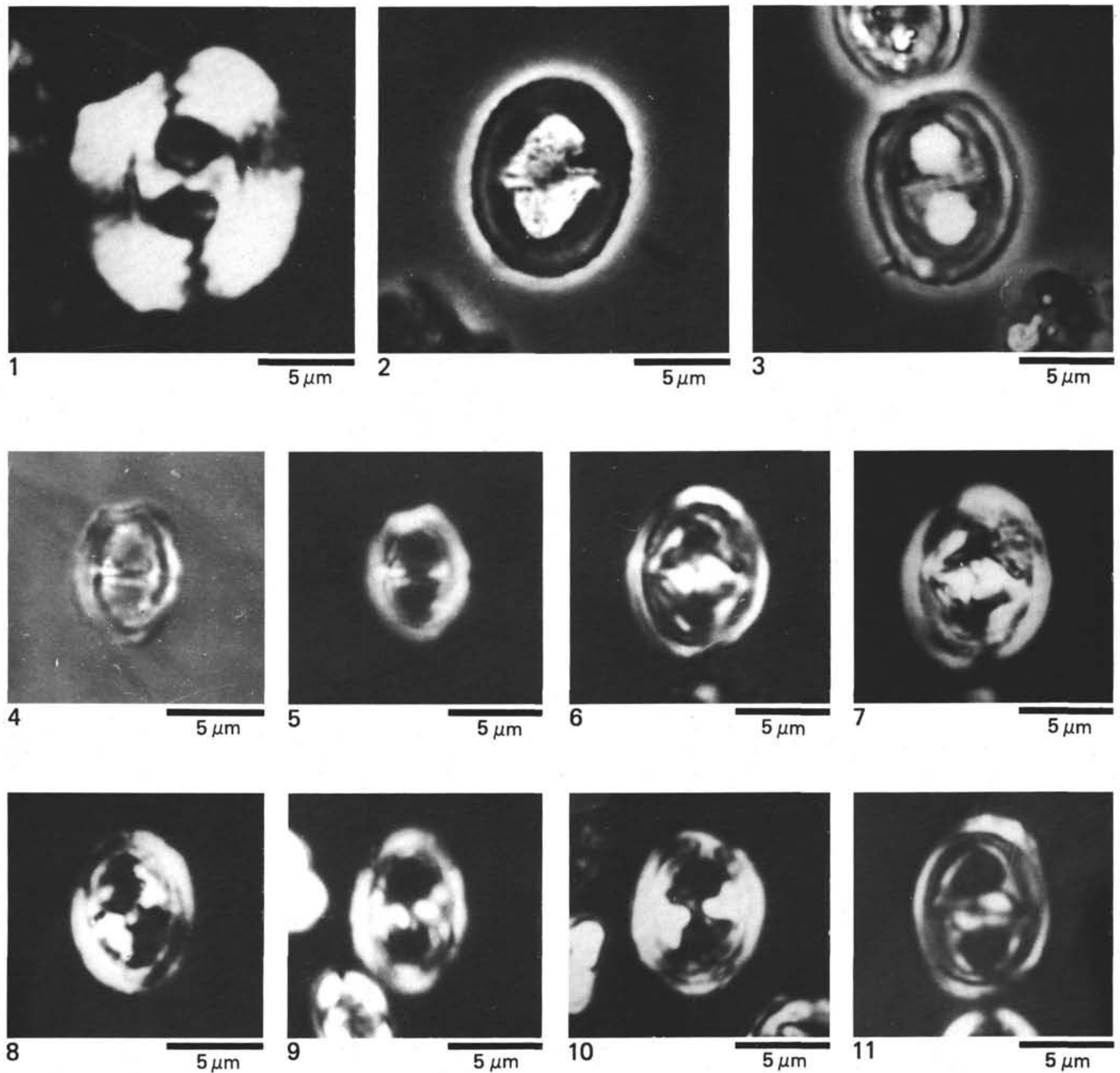

Plate 47. 1. Watznaueria biporta Bukry, 1969. Plane view; XN; Sample 530A-89-1, 80-81 cm; early Santonian. 2, 3, 11. Zygodiscus theta

(Black, 1959) Bukry, 1969. Plane views; PHC; Samples 530A-79,CC (Fig. 2) and 530A-77-2, 142-143 cm (Figs. 3 and 11); early Campanian. 4, 5. Zygodiscus diplogrammus (Deflandre and Fert, 1954) Gartner, 1968. Plane views; NL and PHC; Sample 530A-94-2, 87-88 cm; early Coniacian. 6, 7. Heteromarginatus wallacei Bukry, 1969. Plane view; XN with gypsum plate; XN; Sample 530A-77-2, 142-143 cm; early Campanian. 8-10. Reinhardtites anthophorus (Deflandre, 1959) Perch-Nielsen, 1968. (8) Plane view; XN; Sample 530A-77-2, 142-143 cm; early Campanian (9) Plane view; XN; Sample 530A-94-2, 87-88 cm; early Coniacian. (10) Plane view; XN; Sample 530A-89-1, 80-81 cm; early Santonian. 


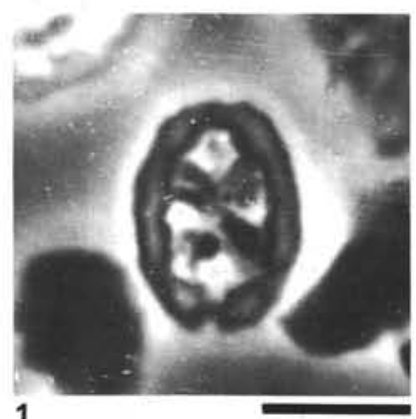

1



5

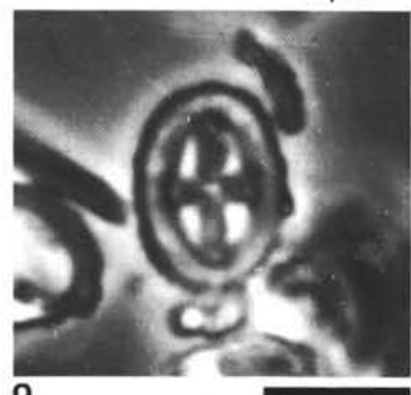

9



13

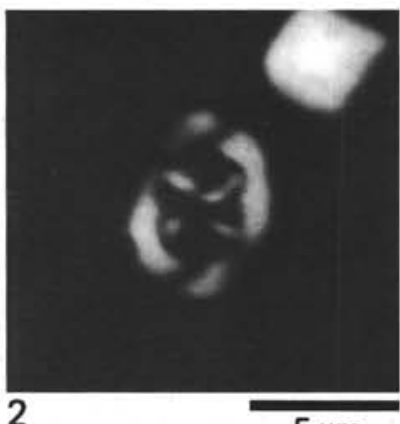

$5 \mu \mathrm{m}$
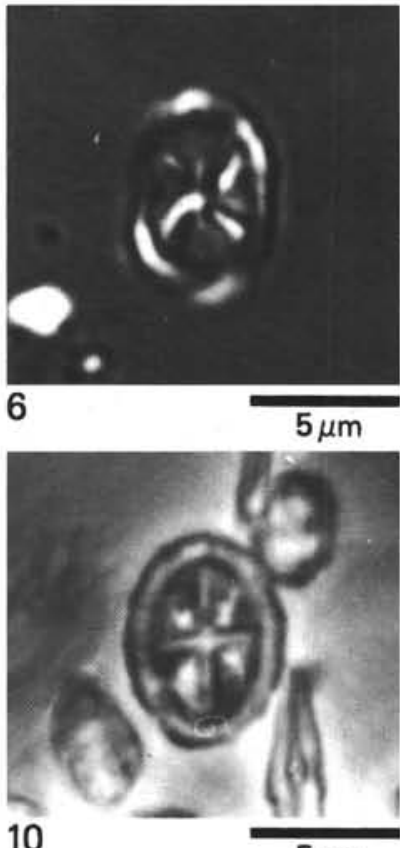

$5 \mu \mathrm{m}$

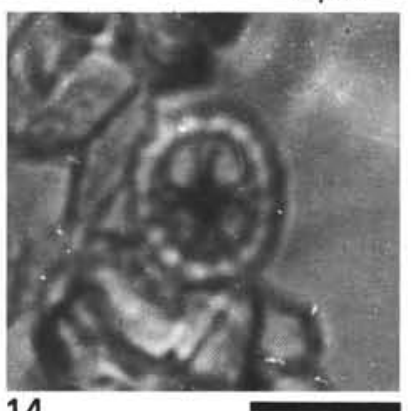

5 um

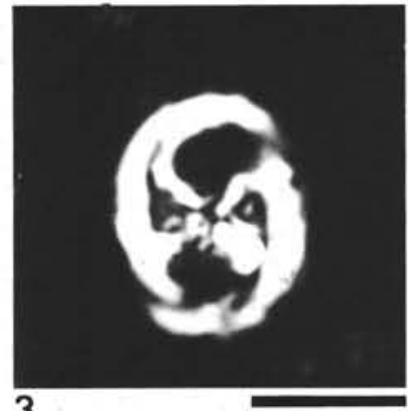

$5 \mu \mathrm{m}$
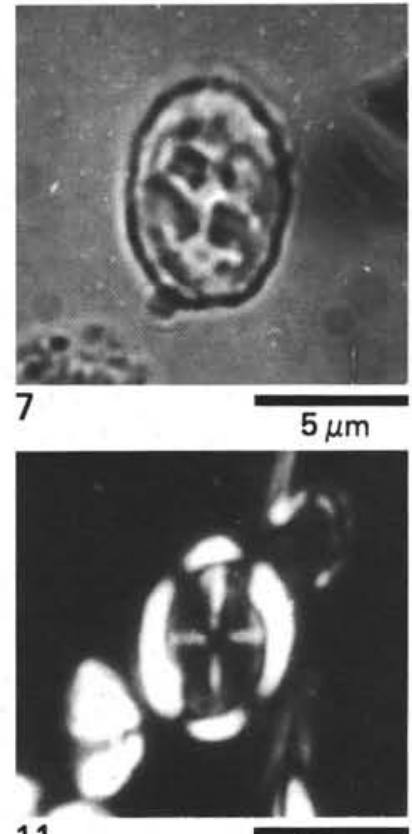

11

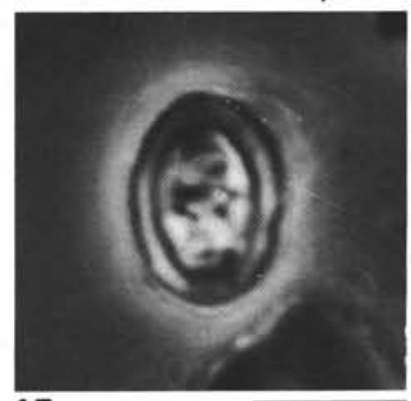

15

$5 \mu \mathrm{m}$
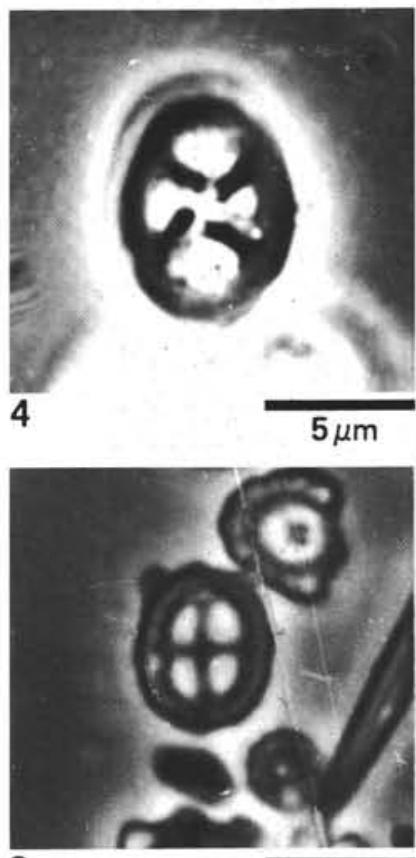

8
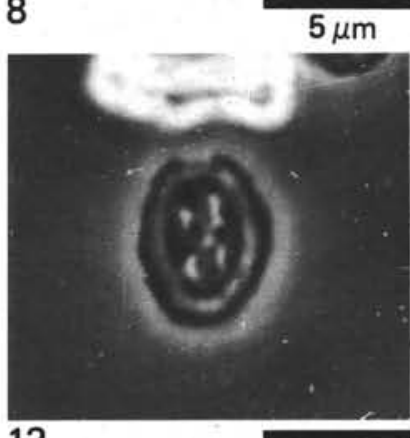

12



16

$5 \mu \mathrm{m}$

Plate 48. 1-6. Chiastozygus litterarius (Gorka, 1957) Manivit, 1971. (1) Sample 530A-89-1, 80-81 cm; early Santonian; PHC. (2, 6) Sample 530A77-7, 110-111 cm; early Campanian and reworked Lower Cretaceous; XN. (3) Sample 530A-105-4, 8-9 cm; late Albian. (4) Sample 530A-79 cc; early Campanian; PHC. (5) Sample 530A-94-2, 87-88 cm; early Coniacian; PHC. 7. Tranolithus orionatus (Reinhardt) Reinhardt, 1966. Sample 530A-79,CC; early Campanian; NL. 8. Vekshinella stradneri Rood, Hay, and Barnard, 1971 . Sample 530A-94-2, 87-88 cm; early Coniacian; PHC. 9-12. Staurolithites matalosus (Stover, 1966) Cepek and Hay, 1969. Sample 530A-94-2, 87-88 cm; early Coniacian. (9, 10, 12) PHC. (11) XN. 13, 14. Prediscosphaera spinosa (Bramlette and Martini, 1964) Gartner, 1968. Samples 530A-50-2, 22-23 cm and 530A-50-1, 16-17 cm; NL. Cretaceous/Tertiary boundary. 15, 16. Zygodiscus spiralis Bramlette and Martini, 1964. Sample 530A-50-1, 16-17 cm. NL and $\mathrm{XN}$; Cretaceous/Tertiary boundary. 


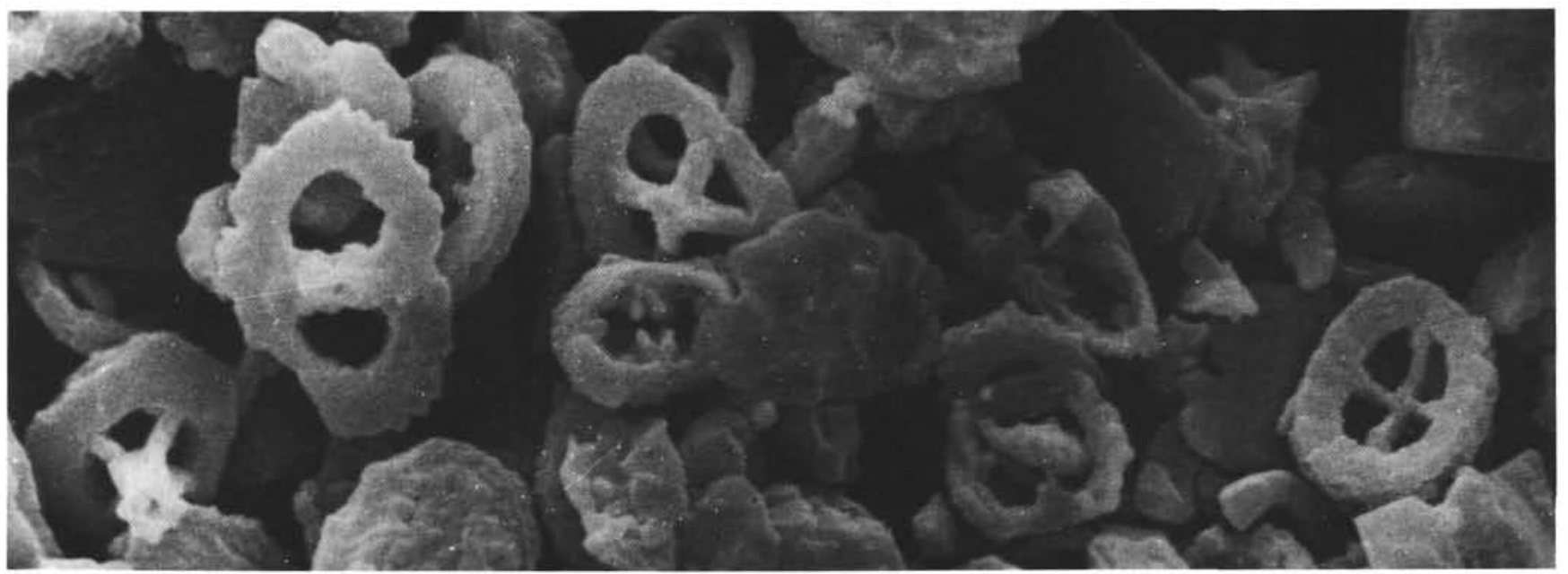

1
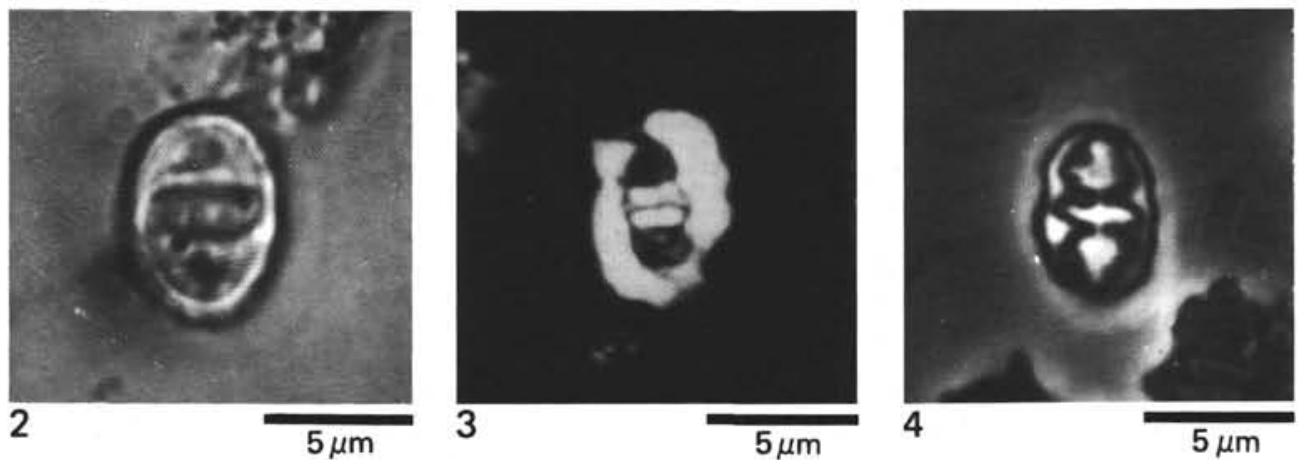

$10 \mu \mathrm{m}$
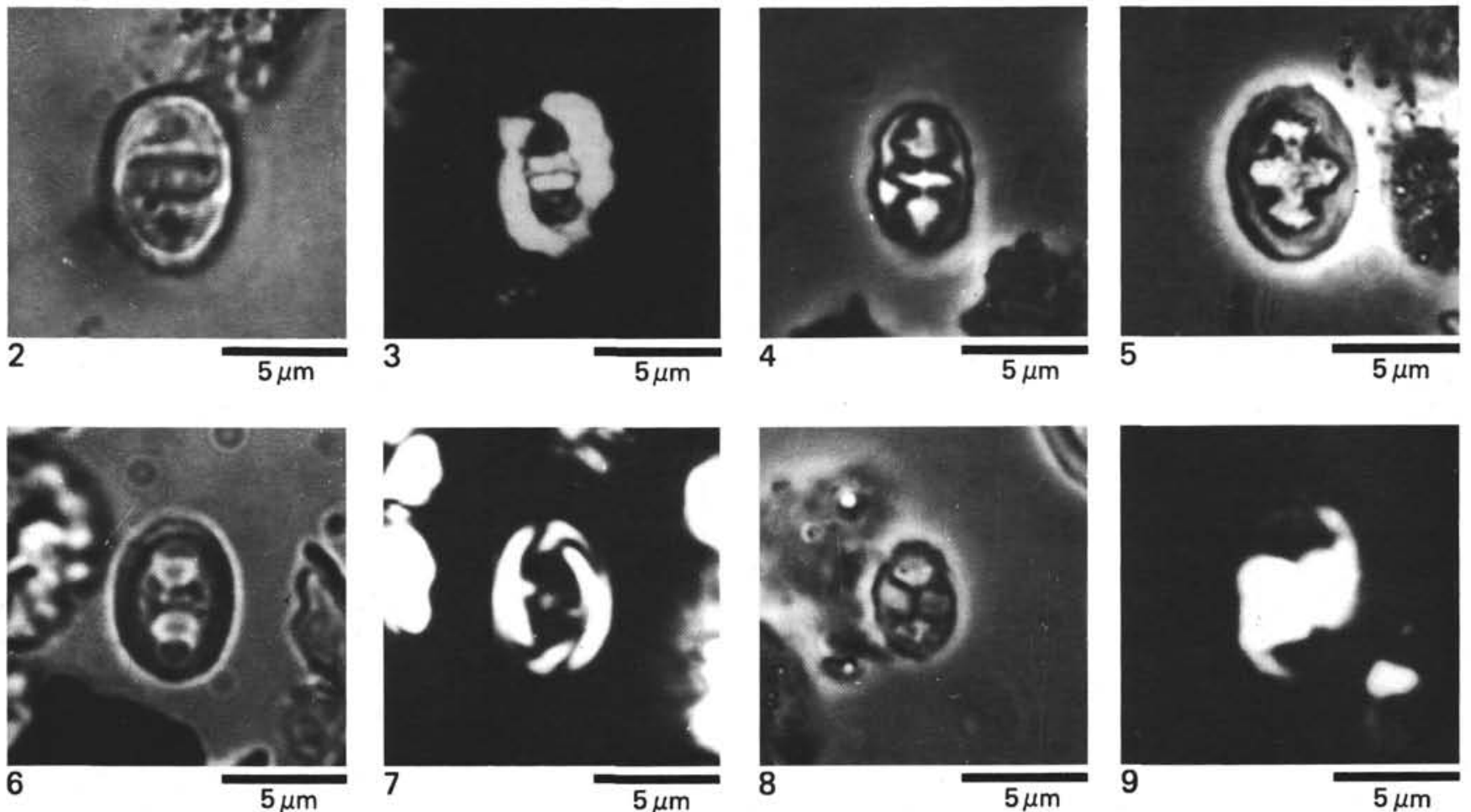

Plate 49. 1. Nannofossil assemblage with representatives of the genera Zygodiscus, Corollithion, and Prediscosphaera. Sample 530A-94-2, 87-88 cm; early Coniacian; SEM. 2-5. Zygodiscus diplogrammus (Deflandre and Fert, 1954) Gartner, 1968. (2) Sample 530A-89-1, 80-81 cm; early Santonian; NL. (3) Sample 530A-105-4, 8-9 cm; late Albian; XN. (4) Sample 530-89-1, 80-81 cm; early Santonian; PHC. (5) Sample 530A-79,CC; early Campanian. 6, 7. Zygodiscus spiralis Bramlette and Martini, 1964. Sample 530A-50-1, 16-17 cm; Cretaceous/Tertiary boundary; NL and XN. 8, 9. Tranolithus gabalus Stover, 1966. (8) Sample 530A-100-2, $98-99 \mathrm{~cm}$; late Cenomanian to early Turonian; PHC. (9) Sample 530A-777, 110-111 cm; early Campanian and reworked Lower Cretaceous; XN. 

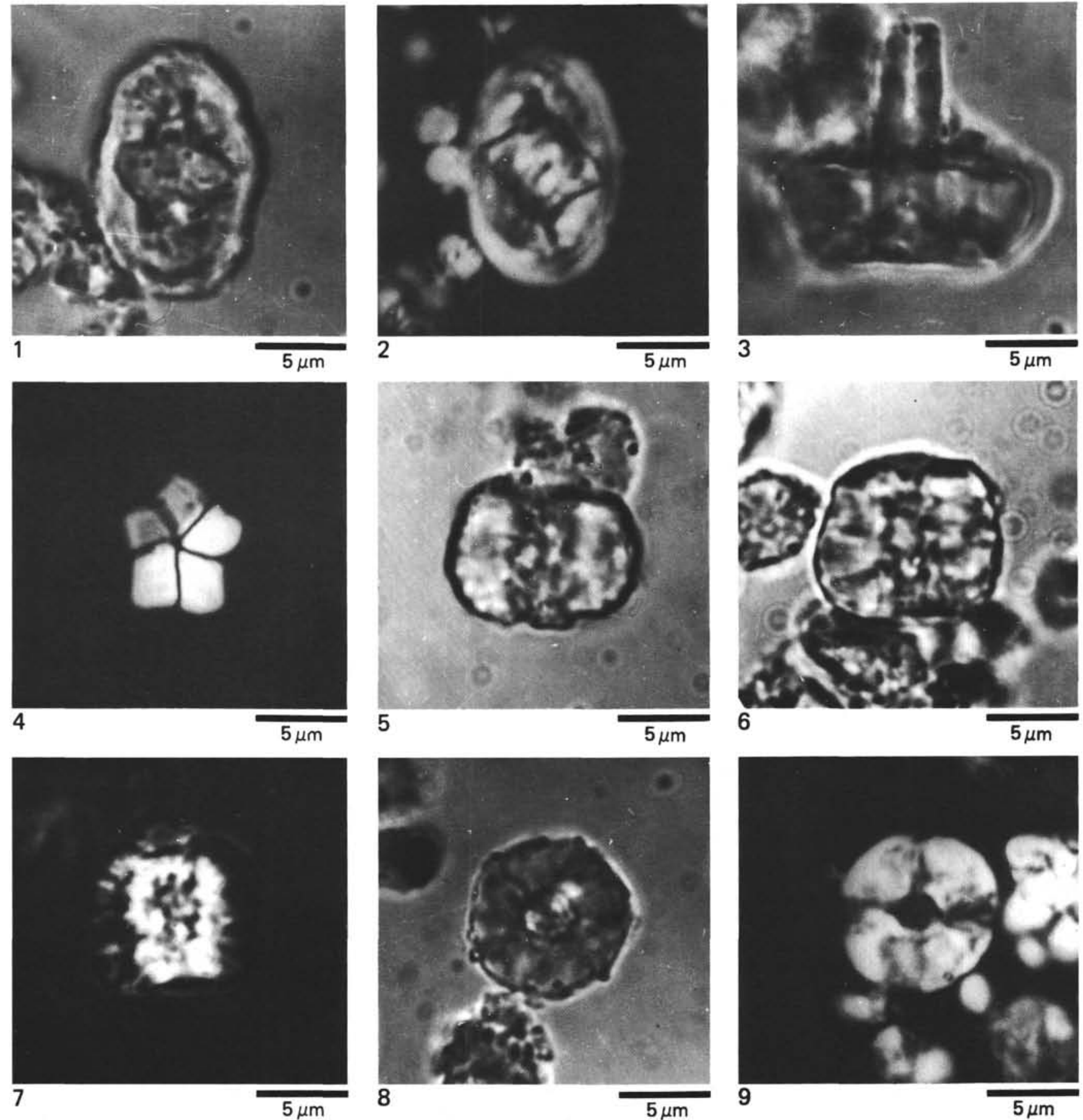

Plate 50. Nannofossils reworked from a Lower Cretaceous near-shore environment; Sample 530A-77-7, 110-111 cm; early Campanian. 1-3. Parhabdolithus embergeri (Noël, 1958) Stradner, 1963. NL and XN; Two plane views and side view. 4. Braarudosphaera africana Stradner 1961. XN. 5-7. Nannoconus globulus Brönnimann, 1955. Lateral views; NL, XN. 8, 9. Nannoconus globulus Brönnimann, 1955. Axial views; NL, XN. 

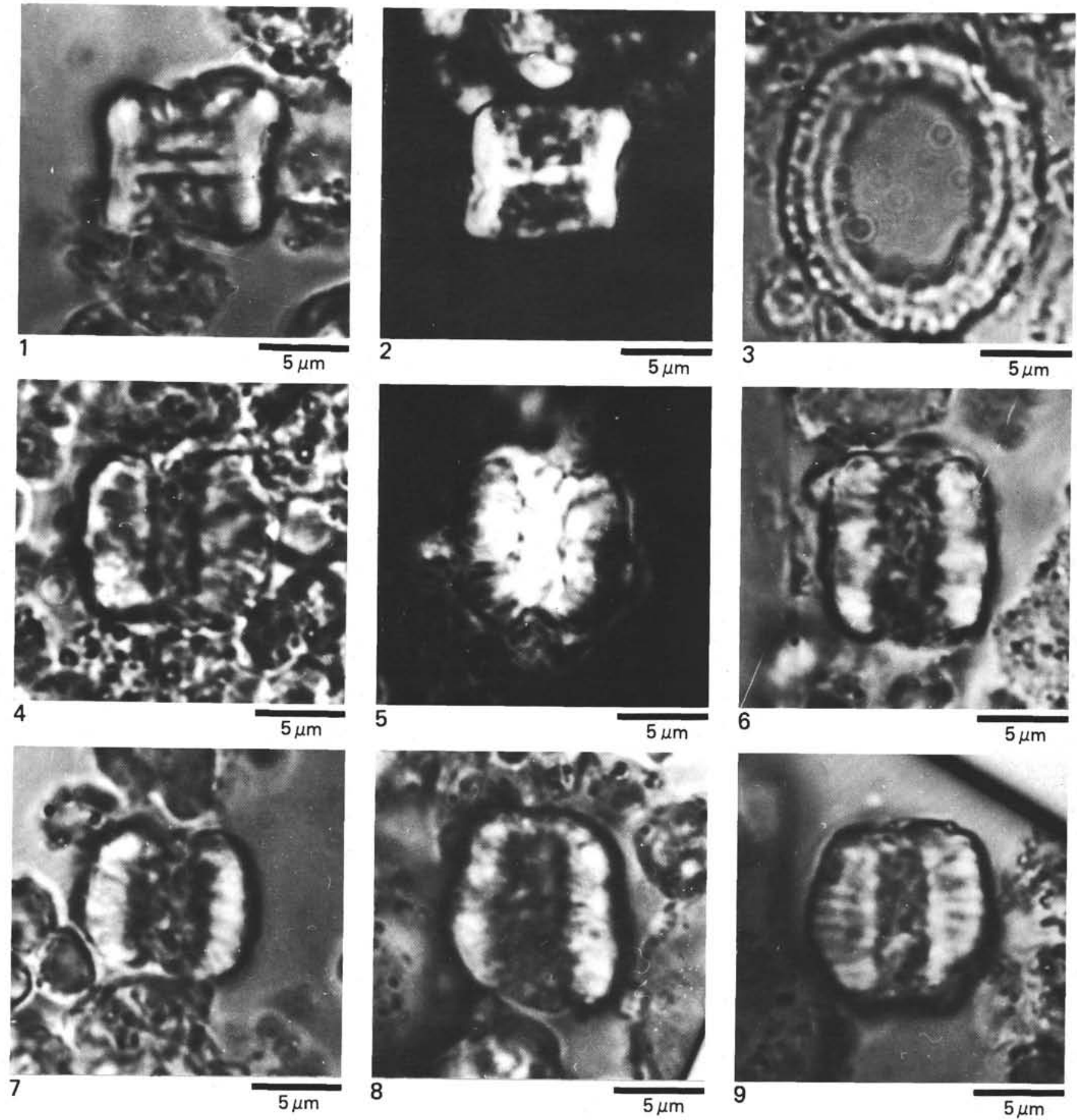

Plate 51. Nannofossils reworked from a Lower Cretaceous near-shore environment; Sample 530A-77-7-110-111 cm; early Campanian. 1, 2. Eprolithus apertior Black, 1973; Side views; NL and XN. 3. Manivitella pemmatoidea (Deflandre, 1965) Thierstein, 1971. Plane view; NL. 4-6. Nannoconus truitti Brönnimann, 1955. Lateral views; NL and XN. 8. Nannoconus bucheri Brönnimann, 1955; lateral view; NL. 7, 9. Intermediate forms of Nannoconus cf. truitti Brönnimann, 1955; NL. 


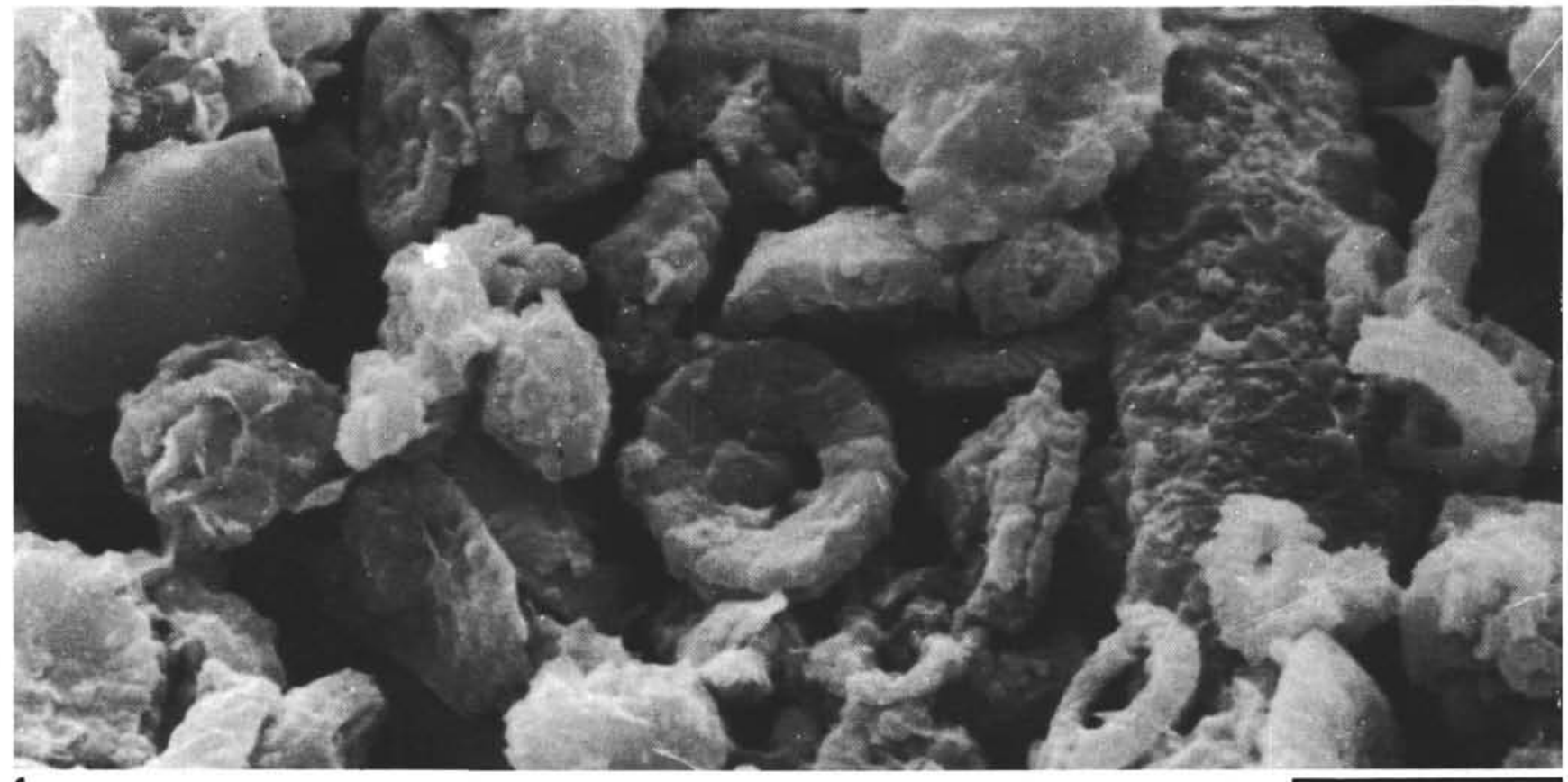

1

$20 \mu \mathrm{m}$
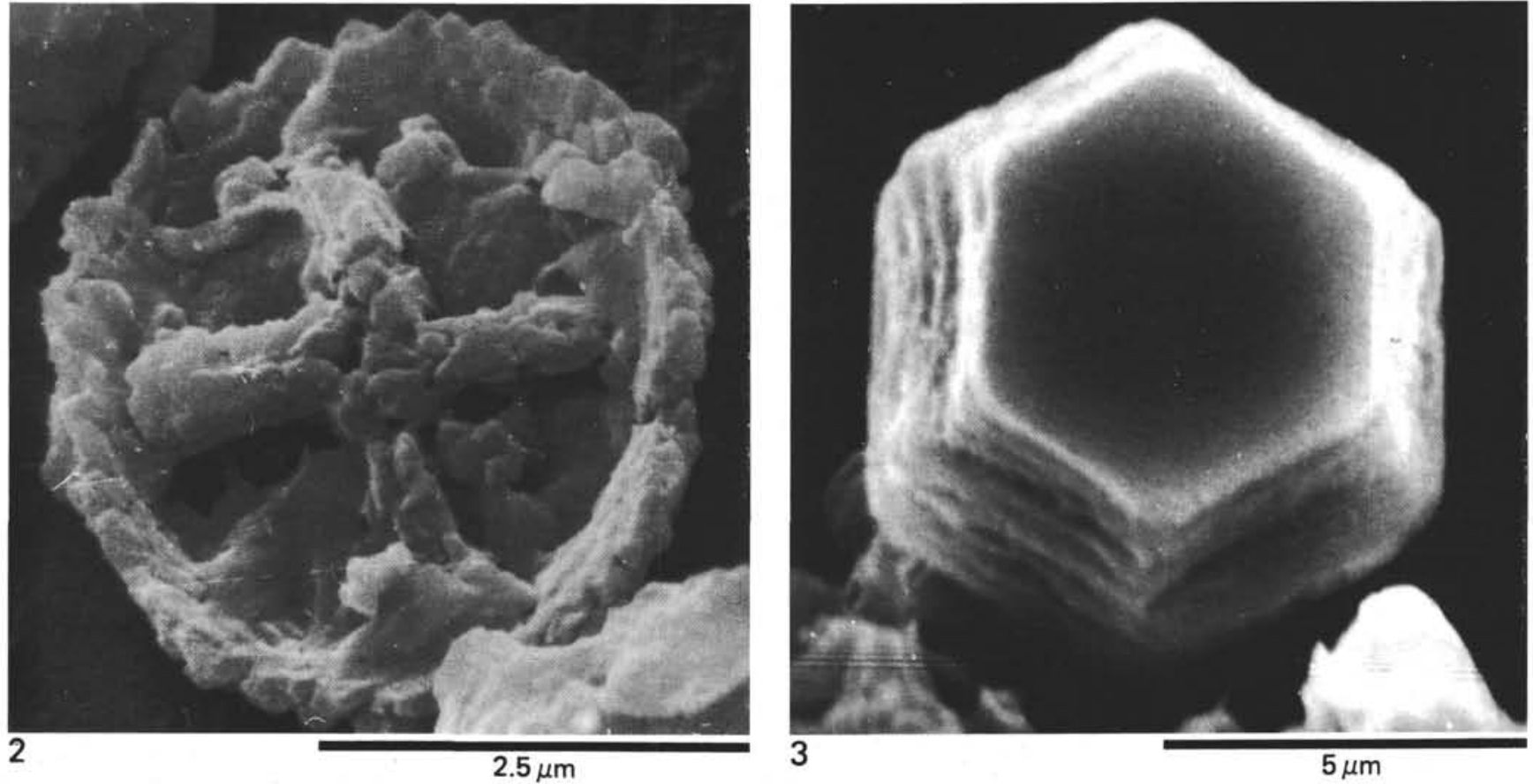

Plate 52. 1. Panoramic view of a poorly preserved nannofossil assemblage; Sample 530A-100-2, 98-88 cm; late Cenomanian to early Turonian. 2. Corollithion baldiae (Stradner and Adamiker, 1966 nov. comb.); Distal view of a poorly preserved specimen; SEM; Sample 530A-100-2, $98-99$ $\mathrm{cm}$; late Cenomanian to early Turonian. 3. Enigmatic hexaprismatic, laminated body of ?biogenic origin; Sample 530A-78,CC; early Campanian; SEM. 